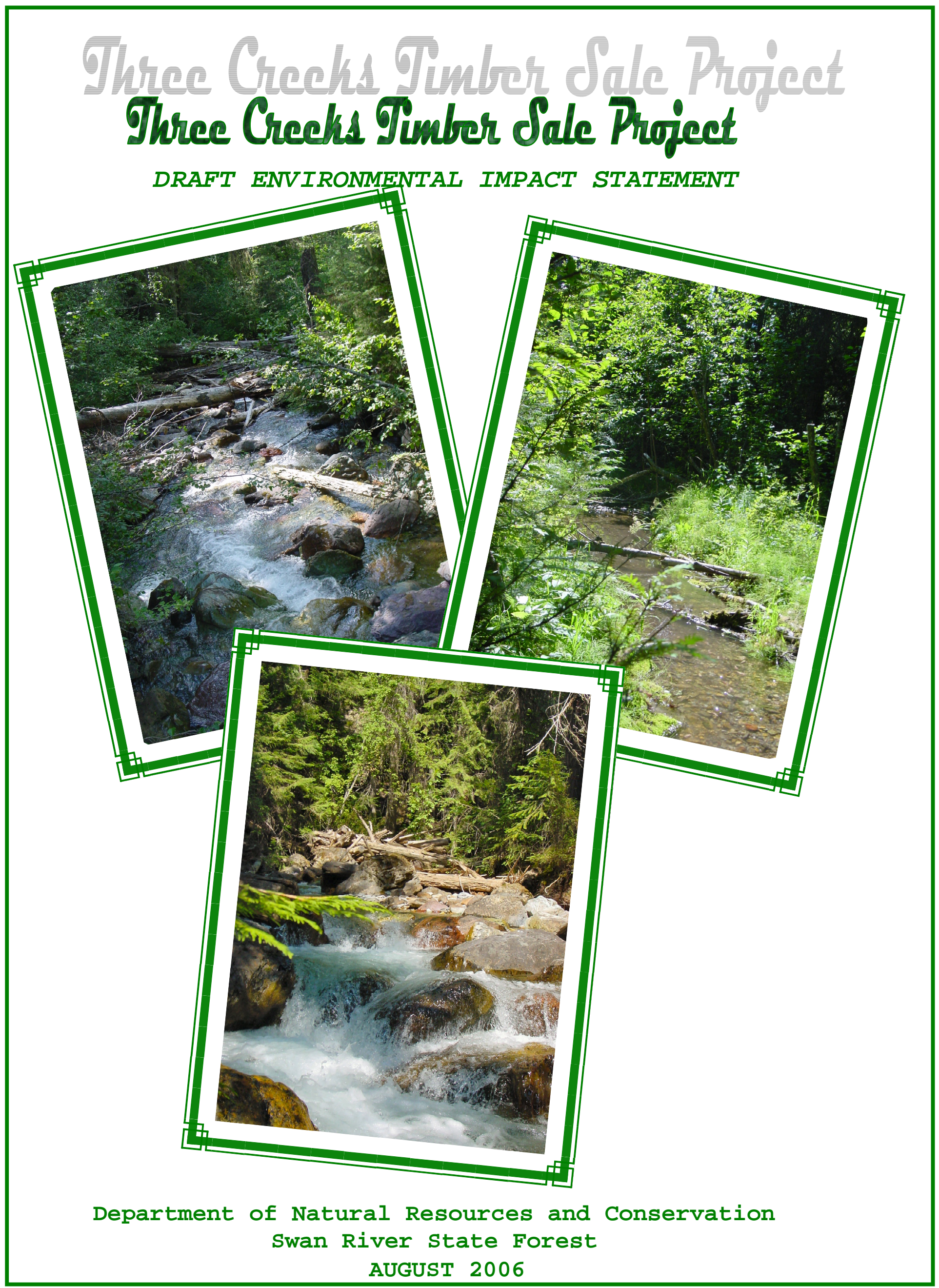




\title{
THREE CREEKS TIMBER SALE PROJECT DRAFT ENVIRONMENTAL IMPACT STATEMENT
}

\begin{abstract}
Enclosed is a copy of the Three Creeks Timber Sale Project Draft Environmental Impact statement (DEIS). I encourage you to carefully review the information presented in the DEIS and provide comments to Karen Jorgenson, Project Leader, Swan River State Forest, 34925 MT Highway 83, Swan Lake, Montana 59911. Comments must be received by
\end{abstract} october 5, 2006. Along with your comments, please be sure to include your name, address, telephone number, and the title of the DEIS for which you are providing comments.

The proposed project is located approximately 7 miles south of Swan Lake, Montana in Swan River State Forest.

The Department does not present a preferred alternative of the four action alternatives analyzed in the DEIS. Proposed harvest volumes range from 0 (No-Action Alternative A) to between 20 and $26 \mathrm{MMBF}$ (Action Alternatives B, C, D, and E).

Old-growth designation and analysis is in a constant state of flux due to lawsuit rulings, Land Board decisions, Guidance modifications, and pending legislation. DNRC will make the necessary adjustments to reflect the most current old-growth situation in either the Final Environmental Impact statement or Record of Decision document.

The Executive Summary incorporates pictures to convey information and is written so that a person of any interest level can understand the contents. The DEIS consolidates Chapters III and IV into one section that summarizes the analysis in plain English. The bulk of the scientific analysis is located in the tabbed Resource Appendices. I hope this format change improves our ability to communicate with all individuals' interest in the management of State lands. I welcome your thoughts and comments.

Sincerely

Daniel J. Roberson

Unit Manager

Swan River State Forest

34925 MT Highway 83

Swan Lake, MT 59911

(406) 754-2301 


\section{THREE CREEKS TIMBER SALE PROJECT \\ DDRAFT ENVIRONMENTAL IMPACT STATEMENT \\ PREFACE}

The Three Creeks Timber Sale

Project Draft Environmental Impact Statement (DESI) format is similar to others written on the Swan River State Forest. This preface explains the format and how to use it to obtain the information of your interest. The key reasons for using this format are:

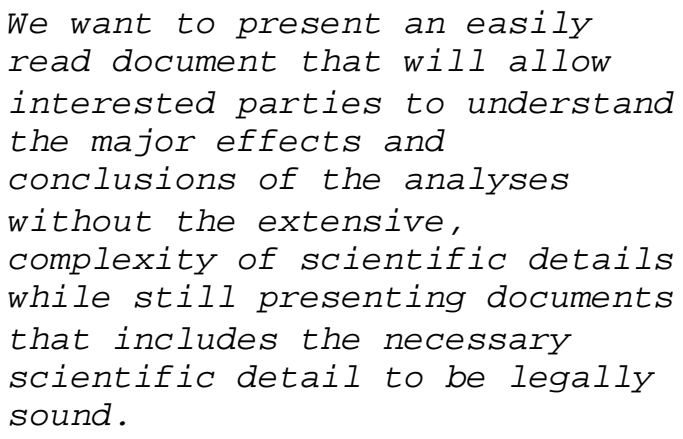

To accomplish these goals, the DEIS is split into 3 separate, but related, parts:

\section{EXECUTIVE SUMMARY}

This portion summarizes the DEIS by briefly describing:

- the proposed action,

- the issues connected with each analysis,

- the alternatives that were considered, and

- the environmental effects of each alternative.

The written information has supporting photographs and maps to make it easily understood.

\section{DEIS}

Chapter I describes the purpose and need of the proposed action and the issues that guided our alternative development and environmental effects analysis.

Chapter II describes the alternatives that were analyzed and compares their effects.
Chapter III displays the existing environment and the environmental effects to each resource for each alternative. The effects analysis is summarized and condensed so that the proposal and its effects can be easily understood. For a more detailed explanation, the Resource Appendixes should be read.

\section{RESOURCE APPENDICES}

The Resource Appendices contain the full technical and scientific discussions of:

- the analysis methods and areas,

- the existing conditions, and

- the direct, indirect, and cumulative effects of the proposed actions on the environment.

The discussions include citations and data from research documents, environmental assessments, and database analyses. Each Interdisciplinary Team (ID Team) member prepared the analysis for his/her individual specialty (fisheries, water, wildlife, etc.). The appendices provide the basis for the information and conclusions that are displayed in the DEIS and Executive Summary. The analyses are summarized in the DEIS; therefore, the information in the appendixes need to be utilized fro scientific, technical, or legal reviews. 
TABLE OF CONTENTS

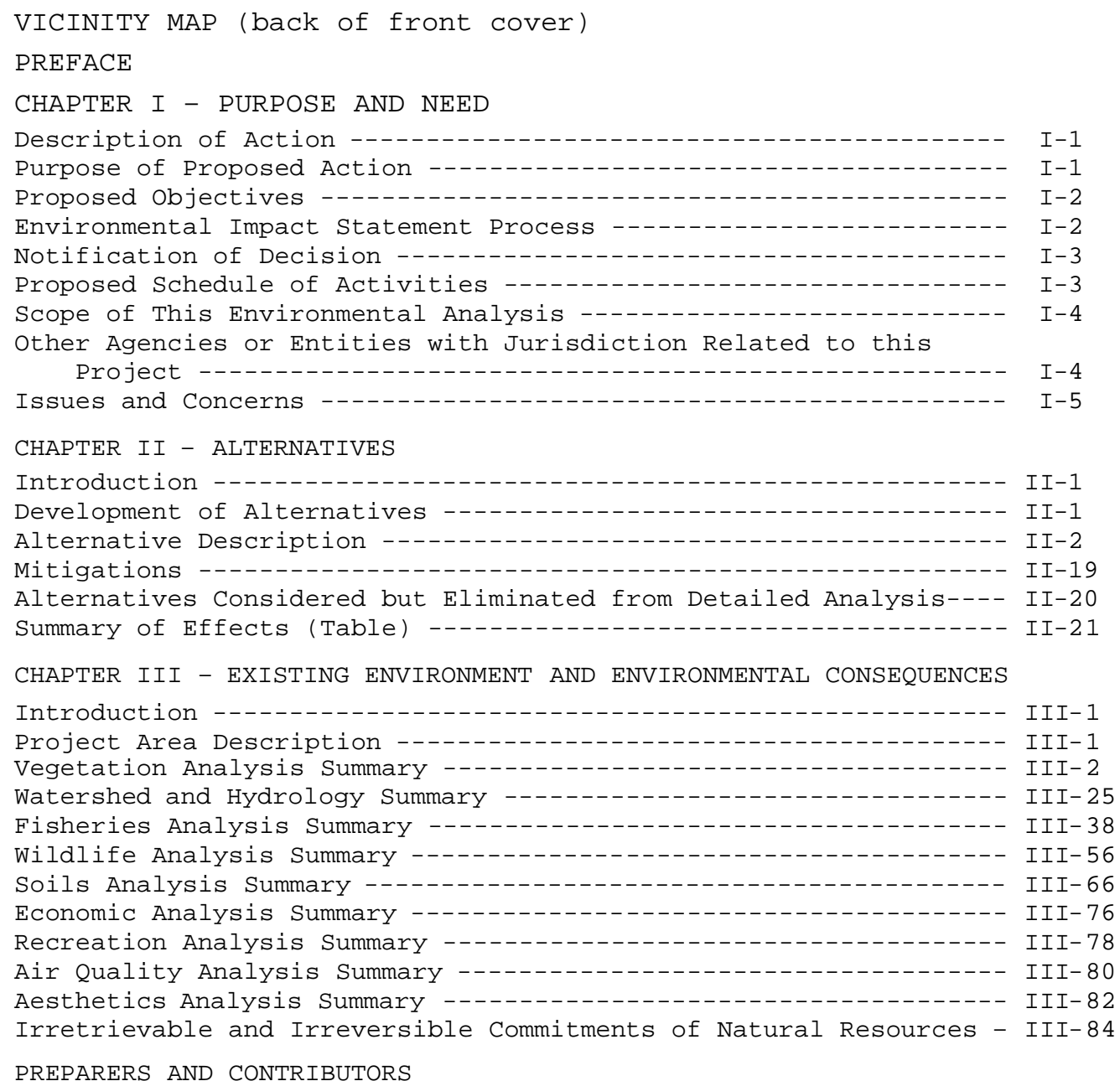

REFERENCES

GLOSSARY

ACRONYMS (front of back cover)

\section{APPENDICES}

Appendix A - Related Reviews

Appendix B - Stipulations and Specifications

Appendix C - Vegetation Analysis

Appendix D - Hydrology Analysis

Appendix E - Fisheries Analysis

Appendix F - Wildlife Analysis

Appendix G - Soils Analysis

Appendix H - Economics Analysis

Appendix I - Recreation Analysis

Appendix J - Air Quality Analysis

Appendix K - Aesthetics Analysis

Appendix L - Scoping List

Appendix M - Glossary

ACRONYMS (front of back cover) 


\section{THREE CREEKS TIMBER SALE PROJECT \\ CHAPTER I \\ PURPOSE AND NEED}

\section{DESCRIPTION OF PROPOSED ACTIONS}

Swan River State Forest, Montana Department of Natural Resources and Conservation (DNRC) is proposing the Three Creeks Timber Sale Project. The proposed project is located approximately 7 air miles southeast of Swan Lake, Montana on school trust lands in the northeast portion of Swan River State Forest. The proposed project includes all or portions of Sections 1, 3, 4, 9, 10, $11,14,15,16,22,25,26$, and 27, Township 24 north (T24N), Range 17 west (R17W).

The project proposal includes harvest alternatives that would:

- reduce insect and disease problems;

- Generate income for the school trusts by harvesting 20 to 26 million board feet (mmbf) of timber from 1,787 to 1,999 acres;

- Improve the long-term management access by constructing 7.5 to 16 miles of new roads and 3 to 7 miles of temporary roads and maintain existing roads to meet current Best Management Practices (BMPs);

- Reduce sediment delivery by relocating a portion of the South Fork of Lost Creek Road to the north of its current location so the road does not contribute sediment to the stream and is no longer within the streamside management zone (smz), preferred habitat for some wildlife species;

- remove 6 old bridges (4 older stream crossings along Soup Creek and 2 crossings in the South Fork of Lost Creek area), rehabilitate the crossing sites, and stabilize the streambanks; and

- replace 1 wooden bridge that presently cannot support heavy machinery or fire engines.
The stream crossings are located in Sections 2, 4, 18, 20, and 25, T24N, R17W and the bridge replacement site is located in section 26, T24N, R17W.

\section{PURPOSE OF PROPOSED ACTION}

The lands involved in the proposed project are held by the state of Montana for the support of specific beneficiary institutions, such as public schools, state colleges and universities, and other specific State institutions, such as the school for the deaf and blind (Enabling Act of February 22, 1889: 1972 Montana Constitution Article $X$, Section 11). The Board of Land Commissioners (Land Board) and DNRC are required by law to administer these trust lands to produce the largest measure of reasonable and legitimate return over the long run for these beneficiary institutions, Section 77-1-2-2, Montana Codes Annotated (MCA).

On May 30, 1996, DNRC released the Record of Decision on the State Forest Land Management Plan (SFLMP). The Land Board approved the SFLMP's implementation on June 17, 1996. On March 13, 2003, the Department adopted Administrative Rules for Forest Management (Rules) (Administrative Rules of Montana [ARM] 36.11.401 through 450). The SFLMP outlines the management philosophy and the proposal would be implemented according to the Rules. The philosophy is:

Our premise is that the best way to produce long-term income for the trust is to manage intensively for healthy and biological diverse forests. Our understanding is that a diverse forest is a stable forest that will produce the most reliable and highest long-term revenue 
stream... In the foreseeable future, timber management will continue to be our primary source of revenue and our primary tool for achieving biodiversity objectives.

\section{PROJECT OBJECTIVES}

In order to meet the goals of the management philosophy adopted through the SFLMP's programmatic review and the Rules, DNRC has set the following specific project objectives:

- Reduce insect and disease problems. Current levels of infestation and mortality are elevated which in turn leads to loss of revenue if left untreated.

- Promote biodiversity by managing for appropriate stand structures and compositions based on ecological characteristics (eg., landtype, habitat type, disturbance regime, unique characteristics). For threatened, endangered, and sensitive species, a fine-filtered approach would be used that focuses on habitat requirements of single species.

- Focus harvesting away from the valley floor. This allows for future winter harvesting opportunities on the valley floor during the period the subunit area is classified as inactive under the Swan Valley Grizzly Bear Conservation Agreement (SVGBCA). This allows Swan River state Forest an opportunity to "rest" the Goat/Squeezer Subunit for recovery of big game thermal cover.

- Provide 20 to 26 mmbf of timber to meet the Northwestern Land Office (NWLO) volume contribution of the annual timber harvest volume on State trust lands that is required by state law (77-5-221 through 223, $M C A)$. This project can be sold in a variety of ways as determined by the needs of the NWLO Forest Management Committee for the years 2007 through 2009.
- Meet BMPs on all project roads, including haul routes to Highway 83.

- Address and rehabilitate sediment point sources within the timber sale project area.

\section{ENVIRONMENTAL IMPACT STATEMENT (EIS) PROCESS}

\section{EIS DEVELOPMENT}

This Draft Environmental Impact Statement (DEIS) was prepared in compliance with the Montana Environmental Policy Act (MEPA), which requires state government to consider environmental impacts in its decision-making process.

Agencies are also required to inform the public and other interested parties about proposed projects, environmental impacts that may result, and alternative actions that could achieve the project objectives.

\section{PUBLIC SCOPING}

Public scoping occurs in the initial stage of the MEPA process and is used to inform the public that a state agency is proposing an action. The public has the opportunity to express their comments or concerns about the possible impacts of the project.

In April 2004, DNRC solicited public participation in the Three Creeks Timber Sale Project proposal by placing notices in the Bigfork Eagle, Kalispell's Daily Inter Lake, and the Swan Valley's Pathfinder newspapers. An article announcing the scoping of the project was also published in the Bigfork Eagle. In addition, a letter that included maps and general information about the project and project area was mailed to individuals, agencies, industry representatives, and other organizations that had expressed interest in Swan River state Forest's management activities. The mailing list developed for this project is in the project file at the Swan River state Forest office. 
The public-comment period for the initial project proposal was open for 45 days. As a result of the letters and notices in the newspapers, a total of 5 letters and 1 phone call were received. The Interdisciplinary Team (ID Team), made up of DNRC's wildlife biologist, hydrologist, economists, foresters, and other specialists, began compiling issues and gathering information related to current conditions in March of 2004.

In November 2004, DNRC completed a required recalculation of the sustained yield for all commercially forested state trust lands; due to the recalculation, the sustained yield changed to 53.2 mbf per year. As part of this process, the Swan River State Forest's annual harvest allocation was 6.7 mbf. This resulted in an increase in the potential harvest under this project. In April 2005, a newsletter updating this project was sent to those on the mailing list; 4 responses were received. The ID Team conducted 3 field tours for interested parties; 2 in June 2005 and 1 in september 2005.

\section{DEIS}

The next step was the preparation of this DEIS. Public comments related to the issues that could affect the project have been incorporated into the DEIS. Upon publication, a letter of notification that the DEIS is available will be sent to individuals on the mailing list. The DEIS, Resource Appendices, and/or Executive Summary will be circulated to individuals that have requested the documents. The DEIS will also be published on the state website at http://dnrc.mt.gov/env_docs/. Comments on the DEIS will be accepted for 45 days.

\section{FINAL ENVIRONMENTAL IMPACT STATEMENT (FEIS)}

After public comments are received, compiled, and addressed, DNRC will prepare an FEIS or adopt the DEIS as the FEIS. The FEIS consists primarily of a revision of the DEIS that incorporates new information that is based on public and internal comments. The FEIS would also include responses to substantive comments received on the DEIS.

\section{NOTIFICATION OF DECISION}

Following publication of the FEIS, the decisionmaker will review public comments, the FEIS, and information contained in the project file. No sooner than 15 days after publication of the FEIS, the decisionmaker will consider and determine the following:

- Do the alternatives presented in the FEIS meet the project's purpose?

- Is the proposed mitigation adequate and feasible?

- Which alternative (or combination/modification of alternatives) should be implemented and why?

These determinations will be published, and all interested parties will be notified. The decisions presented in the published document would become recommendations from DNRC to the Land Board. Ultimately, the Land Board would make the final decision regarding which action to implement.

\section{PROPOSED SCHEDULE OF ACTIVITIES}

After the decision is published, and if a timber-harvesting alternative is selected, a Timber sale contract package would be prepared in the fall of 2006. A second, and possibly third, contract package would be prepared in the fall and winter of 2006/2007 and the summer of 2007. The first contract package is tentatively scheduled for presentation to the Land Board in December 2006. If the Land Board approves the timber sale, the sale may be advertised that fall. separate contracts would be 
presented to the Land Board and, upon approval, the timber volume would be advertised the following spring of 2007 and fall/winter of 2007. Harvest treatment and roadwork activities would occur for approximately 2 to 3 years after the sale is sold. Post-treatment

activities, such as site

preparation, planting, and hazard reduction, would occur following the harvest activities.

\section{SCOPE OF THIS ENVIRONMENTAL ANALYSIS}

OTHER ENVIRONMENTAL REVIEWS RELATED TO THE PROJECT

In order to address direct, indirect, and cumulative effects on many resources, the analysis must incorporate past, present, and future actions within a determined analysis area. The locations and sizes of the analysis areas vary by resource (watershed, soils, etc.) and species (grizuly bear, Canada lynx, etc.) and are further described by resource in CHAPTER III - EXISTING ENVIRONMENT AND ENVIRONMENTAL CONSEQUENCES and the various resource appendices. The following timber sales are located within Swan River State Forest:

- Ongoing timber sales where the environmental analysis has been completed:

- Goat Squeezer Timber Sale Project EIS (2003)

- Goat Squeezer I Timber Sale Project

- Goat Squeezer II Timber Sale Project

- Goat Squeezer III Timber Sale Project

- Triple D Salvage Permit Checklist Environmental Assessment (CEA) (2005)

- Cilly Bug Salvage Sale CEA (2005)

- Rock Squeezer Salvage Sale CEA (2005)
- Red Ridge Salvage Permit CEA (2006)

- The Fridge Salvage Permit is currently in the environmental review process.

- The White Porc Timber Sale Project has been identified on DNRC's future timber sale list as the next potential project on Swan River state Forest. Currently, no proposal/proposed action has been initiated and the potential project has not been scoped; therefore, DNRC has not initiated a preimpact study on this proposal.

\section{OTHER AGENCIES OR ENTITIES WITH JURISDICTION RELATED TO THIS PROJECT MONTANA DEPARTMENT OF FISH, WILDLIFE, AND PARKS (DFWP)}

DFWP has jurisdiction over the management of fisheries and wildlife in the project area. A stream Preservations Act Permit (124 Permit) is required from DFWP for activities that may affect the natural shape and form of any stream or its banks or tributaries.

\section{MONTANA DEPARTMENT OF ENVIRONMENTAI QUALITY (DEQ)}

A Short-Term Exemption from Montana's Surface Water Quality Standards (3A Authorization) may be required if temporary activities would introduce sediment above natural levels into streams, or DFWP feels a permit is necessary after reviewing the mitigation measures in the 124 Permit.

\section{MONTANA/IDAHO AIRSHED GROUP}

DNRC is a member of the Montana/Idaho Airshed Group, which regulates DNRC's prescribed fires. DNRC receives air-quality permits through participation in the Montana/Idaho Smoke Monitoring Unit. 
UNITED STATE FISH AND WILDLIFE SERVICE (USFWS)

The SVGBCA, a cooperative agreement between DNRC, Plum Creek Timber Lands, USFWS, and United States Forest Service (USFS) is currently in effect. The SVGBCA defines mitigation measures for timberharvesting operations within the Grizzly Bear Recovery Zone. This project will operate within the parameters of the SVGBCA.

\section{USFS}

Cooperative road-maintenance activities by DNRC and USFS reduce sediment delivery from roads.

\section{ISSUES AND CONCERNS}

Through the scoping process, resource specialists of DNRC, other agencies, and the public, raised concerns about the project's potential impacts on the environment. DNRC used these concerns in developing the project design, mitigation measures, and alternatives (CHAPTER II ALTERNATIVES). A summary of the comments incorporated into the alternatives is presented in TABLE I-1 - SUMMARY AND TRACKING OF ISSUES AND CONCERNS FROM PUBLIC COMMENTS. 
TABLE I-1 - SUMMARY AND TRACKING OF ISSUES AND CONCERNS FROM COMMENTS

\begin{tabular}{|c|c|c|}
\hline $\begin{array}{l}\text { RESOURCE } \\
\text { AREA }\end{array}$ & $\begin{array}{l}\text { CONCERN } \\
\text { OR ISSUE }\end{array}$ & $\begin{array}{l}\text { WHERE ADDRESSED } \\
\text { IN EIS }\end{array}$ \\
\hline \multirow[t]{7}{*}{ Vegetation } & $\begin{array}{l}\text { Timber harvesting reduces the amount of old } \\
\text { growth and removes important old-growth } \\
\text { attributes. }\end{array}$ & $\begin{array}{l}\text { Pages III }-15 \\
\text { through } 20 \\
\text { Pages C }-34 \text { through } \\
36\end{array}$ \\
\hline & $\begin{array}{l}\text { Maintain long-term productivity and manage } \\
\text { for a healthy and biologically diverse } \\
\text { forest. }\end{array}$ & $\begin{array}{l}\text { Pages C - } 3 \text { through } \\
6\end{array}$ \\
\hline & $\begin{array}{l}\text { The project should maintain the quantity and } \\
\text { quality of old growth on Swan River State } \\
\text { Forest, with particular emphasis in the } \\
\text { valley bottom and lower elevation. }\end{array}$ & $\begin{array}{l}\text { Pages III }-15 \\
\text { through } 20 \\
\text { Pages C }-33 \text { through } \\
36\end{array}$ \\
\hline & $\begin{array}{l}\text { Current fragmentation (edge to interior } \\
\text { ratio) is high and may increase with future } \\
\text { projects. }\end{array}$ & $\begin{array}{l}\text { Pages III }-10 \\
\text { through } 12 \\
\text { Pages C }-20 \text { through } \\
22\end{array}$ \\
\hline & $\begin{array}{l}\text { Implement silvicultural prescriptions that } \\
\text { are beneficial to long-term management goals } \\
\text { and address insect and disease activity. }\end{array}$ & $\begin{array}{l}\text { Pages III }-4 \\
\text { through } 9 \text { and } 12 \\
\text { through } 13 \\
\text { Pages C }-27 \text { through } \\
28 \text { and } 8 \text { through } 16\end{array}$ \\
\hline & $\begin{array}{l}\text { Because there are large areas of dead and } \\
\text { dying timber in the project area, a } \\
\text { landscape-level analysis of the proportion } \\
\text { and distribution of fire-condition classes } \\
\text { should be used to prioritize stands for } \\
\text { treatment to reduce fuel buildup. }\end{array}$ & $\begin{array}{l}\text { Pages III }-13 \\
\text { through } 15 \\
\text { Pages C }-28 \text { through } \\
32\end{array}$ \\
\hline & $\begin{array}{l}\text { Prescribe silvicultural treatments that move } \\
\text { stands toward historic conditions. }\end{array}$ & $\begin{array}{l}\text { Pages III }-4 \\
\text { through } 9 \\
\text { Pages } C-8 \text { through } \\
16\end{array}$ \\
\hline \multirow[t]{5}{*}{ Wildlife } & $\begin{array}{l}\text { Timber harvesting, road construction, and } \\
\text { road use could cause displacement of } \\
\text { wildlife species due to disturbance and } \\
\text { habitat modification, especially grizzly } \\
\text { bears, Canada lynx, and other species of } \\
\text { concern (threatened and endangered species } \\
\text { and old-growth-dependent species). }\end{array}$ & $\begin{array}{l}\text { Pages III - } 59 \\
\text { through } 60\end{array}$ \\
\hline & $\begin{array}{l}\text { Timber harvesting and road construction } \\
\text { could affect the current and future } \\
\text { fragmentation of wildlife habitat and } \\
\text { security needs of wildlife species. }\end{array}$ & $\begin{array}{l}\text { Pages III - } 60 \\
\text { through } 63\end{array}$ \\
\hline & $\begin{array}{l}\text { Timber harvesting, road construction, and } \\
\text { road use could sever movement corridors. }\end{array}$ & Pages III - 60 \\
\hline & $\begin{array}{l}\text { Timber harvesting and road construction } \\
\text { could result in decreased wildlife habitat, } \\
\text { resulting in decreased wildlife population. }\end{array}$ & $\begin{array}{l}\text { Pages III - } 61 \\
\text { through } 62 \text { and } 64 \\
\text { through } 66\end{array}$ \\
\hline & $\begin{array}{l}\text { Timber harvesting could reduce old-growth } \\
\text { habitats that require a long time to } \\
\text { develop. }\end{array}$ & Pages III - 63 \\
\hline
\end{tabular}




\begin{tabular}{|c|c|c|}
\hline \multirow[t]{3}{*}{ Fisheries } & $\begin{array}{l}\text { The delivery of sediment (and other forms of } \\
\text { pollution) to streams in the project area as } \\
\text { a result of an action alternative could have } \\
\text { a negative effect on native fish. }\end{array}$ & $\begin{array}{l}\text { Pages III - } 59 \\
\text { through } 60 \text { and } 57 \\
\text { through } 68\end{array}$ \\
\hline & $\begin{array}{l}\text { Changes in stream temperature as a result of } \\
\text { an action alternative may have a negative } \\
\text { effect on native fish. }\end{array}$ & $\begin{array}{l}\text { Pages III }-53 \\
\text { through } 54 \text { and } 89 \\
\text { through } 92\end{array}$ \\
\hline & $\begin{array}{l}\text { The recruitment of large woody debris to } \\
\text { streams is important for maintaining natural } \\
\text { stream morphology and features. }\end{array}$ & $\begin{array}{l}\text { Pages III }-52 \\
\text { through } 53 \text { and } 83 \\
\text { through } 89\end{array}$ \\
\hline \multirow[t]{2}{*}{ Hydrology } & $\begin{array}{l}\text { Project design should include a mitigation } \\
\text { measure for sediments caused by humans and } \\
\text { nonpoint source pollution. }\end{array}$ & \multirow[t]{2}{*}{$\begin{array}{l}\text { Pages III }-28 \\
\text { through } 32 \\
\text { Pages D }-28 \text { through } \\
32\end{array}$} \\
\hline & $\begin{array}{l}\text { Areas of existing known sources of } \\
\text { management-caused sediment should be } \\
\text { restored with this project. }\end{array}$ & \\
\hline \multirow[t]{4}{*}{ Economics } & $\begin{array}{l}\text { The project should be fiscally sound, good } \\
\text { for the local economy, and promote job } \\
\text { creation. }\end{array}$ & \multirow[t]{4}{*}{$\begin{array}{l}\text { Pages III }-74 \\
\text { through } 76 \text { and } 3 \\
\text { through } 9\end{array}$} \\
\hline & $\begin{array}{l}\text { Timber harvesting might not generate } \\
\text { adequate funds for the trusts due to the } \\
\text { current and foreseeable amounts of timber on } \\
\text { the market. }\end{array}$ & \\
\hline & $\begin{array}{l}\text { A broader long-term economic analysis should } \\
\text { include more information than a short-term } \\
\text { cash-flow analysis. }\end{array}$ & \\
\hline & $\begin{array}{l}\text { Ensure that road development is economically } \\
\text { feasible and meets current and future } \\
\text { management objectives. }\end{array}$ & \\
\hline
\end{tabular}




\section{CHAPTER II \\ ALTERNATIVES}

\section{INTRODUCTION}

The purpose of this chapter is to introduce 4 action alternatives for the Three Creeks Timber Sale Project and summarize the effects of each action alternative and the no-action alternative. This chapter will focus on the development of the action alternatives, specifically describe each alternative, and briefly outline the predicted environmental consequences associated with each. TABLE II-2 SUMMARY OF ENVIRONMENTAL EFFECTS summarizes the detailed environmental effects analysis from CHAPTER III - EXISTING ENVIRONMENT AND ENVIRONMENTAL CONSEQUENCES and the various resource appendices.

\section{DEVELOPMENT OF ALTERNATIVES}

An ID Team to work on the Three Creeks Timber Sale Project was formed in the fall of 2003. The role of an ID Team is to summarize issues and concerns, develop management options within the project area, and analyze the potential impacts of a proposal on the human and natural environments.

DNRC began reviewing resources in this area with prior projects, the Middle Soup Creek and South Fork Lost Creek timber sale proposals, which were never implemented. Data was collected for resources within the project area to aid in the analyses of wildlife habitat, hydrology, fisheries, old-growth timber stands, the feasibility of timber harvesting, transportation systems, and economics. Data was also used to develop mitigation measures that could be applied to those projects.

Swan River State Forest plans timber sale projects in accordance with the rotation set forth in the SVGBCA. The SVGBCA allows for green timber sales for a 3-year period, followed by 7 years of limited disturbance on a rotating subunit basis within Swan Valley. The South Fork Lost Subunit was originally scheduled to be open for green timber sales from 2006 through 2008. Swan River State Forest applied for, and was granted, an exception from the USFWS to move the dates when the subunit would be open. The South Fork Lost Creek Subunit is now open for green timber sales from 2007 through 2009. The Three Creeks Timber Sale Project area is located entirely within this subunit. If the project extends past December 31, 2009, the remaining units would be harvested during the denning season, between November 16 and March 31, to maintain compliance with the SVGBCA.

Foresters provided the ID Team with a harvest and road proposal to meet the desired future forest conditions on Swan River state Forest and the objectives described in CHAPTER I PURPOSE AND NEED of this DEIS. The proposal addresses insect and disease activities in the project area and provides an opportunity to move stands towards a desired future condition that is more consistent with historic conditions. The ID Team further developed the proposal within the framework of the SFLMP and the Rules. The ID Team discussed how to address public and internal issues, mitigations required by the Rules, and additional mitigations that may be implemented to avoid or reduce effects related to the project. 


\section{ALTERNATIVE DESCRIPTIONS}

This section describes No-Action Alternative $A$ and the developed Action Alternatives B, C, D, and E.

\section{NO-ACTION ALTERNATIVE A}

No large-scale timber harvesting or roadwork would take place, although salvage logging and firewood gathering in areas with public access would likely continue. Road reconstruction beyond coordinated maintenance agreements would not be conducted. The bridge over Soup Creek, the South Fork Lost Creek Road relocation, and the rehabilitation sites would not be completed at this time.

Current road restrictions would remain the same. Recreational uses, such as hunting, fishing, berry picking, and snowmobiling, would continue.

Fire-suppression and weed-control efforts would continue.

Natural events, including plant or forest succession, windthrow, insect and disease outbreaks, and wildfires, would continue to occur. Future actions, including timber harvesting, would be proposed and undergo environmental analysis before implementation.

No-Action Alternative A, which can be used as a baseline for comparing the environmental consequences of Action Alternatives $B, C, D$ and $E$, is considered a viable alternative for selection.

\section{ACTION ALTERNATIVE B}

The primary objective of this alternative is to address insect and disease issues within the project area. The project area is being affected by the Douglas-fir bark beetle, mountain pine beetle, fir engraver, mistletoe, Indian paint fungus, and root disease. Stands within the project area with the highest concentration of ongoing activity have been proposed for harvesting under this alternative. Mortality within these stands is also high, which, in turn, leads to a loss of revenue. Approximately $23.7 \mathrm{mmbf}$ would be harvested from an estimated 1,884 acres. The 4 silvicultural prescriptions proposed under this alternative are listed under Timber-Management Activities. More detailed descriptions of silvicultural prescriptions, including photographs, are presented under Silvicultural Treatments and TABLE II-1 - HARVEST SYSTEM AND SILVICULTURAL AND POSTHARVEST TREATMENTS FOR ACTION ALTERNATIVES $B, C, D, A N D E$. A description of the road construction to be implemented under this proposed alternative is provided under Roadwork Activities. FIGURE II-I - STANDS PROPOSED FOR HARVESTING WITH ACTION ALTERNATIVE $B$ is provided for reference following Roadwork Activities.

\section{- Timber-Management Activities}

Action Alternative B proposes to harvest timber by utilizing 4 types of silvicultural methods:
Commercial thin
553 acres
Shelterwood 654 acres
Seedtree with reserves 543 acres Seedtree 134 acres
This alternative would harvest in 1,221 acres of old growth. of the 1,221 acres, 658 acres would continue to be classified as old growth, while the remaining 564 acres would no 
FIGURE II-1 - STANDS PROPOSED FOR HARVESTING WITH ACTION ALTERNATIVE B

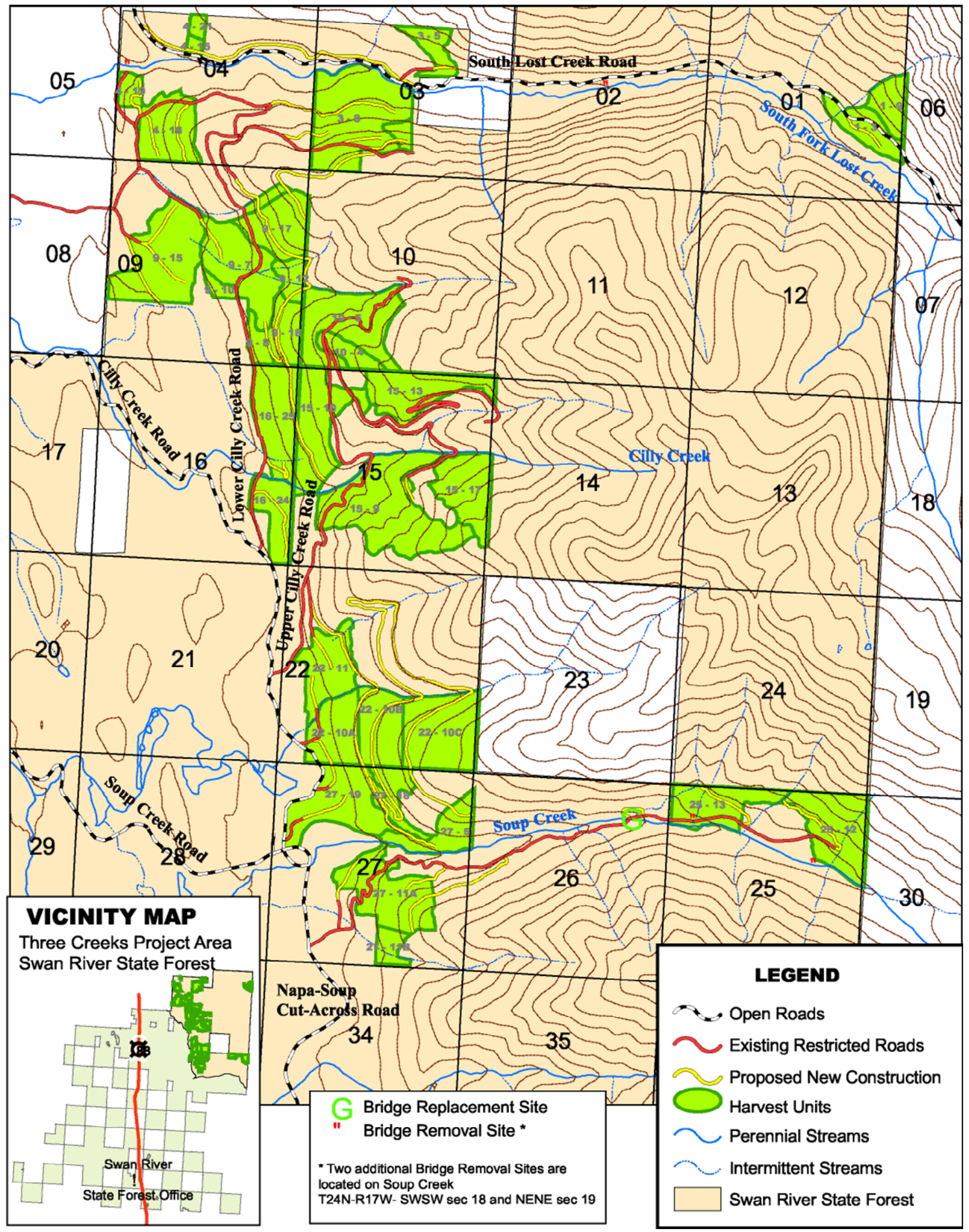

Chapter II - Alternatives

Page II-3 
longer meet the old-growth definition. Due to the varied terrain, the proposed units would be harvested by helicopter, conventional groundbased equipment, and skyline cable systems. Postharvest treatments would include piling slash, scarifying where needed, and, in some cases, broadcast burning. These activities would prepare the sites for the planting of western larch, western white pine, and ponderosa pine seedlings.

\section{- Roadwork Activities}

Approximately 47 miles of existing roads accessing the harvest area would require various levels of improvements and maintenance. Approximately 3 miles of road reconstruction, an estimated 13 miles of new road construction, and 6 miles of temporary roads would be needed to access all the harvest units included in this

alternative. Two miles of existing road would be obliterated. All road segments would be used for administrative and logging purposes. Some of the roads are open year-round to all users. Following logging and site-preparation operations, grass seed would be distributed on the roads to stabilize the roadbeds and prevent erosion and weed establishment.

This proposal would improve a bridge crossing on soup Creek.
The old bridge would be removed and the site would be upgraded to fit a temporary bridge that would provide access for harvesting activities. Following postharvest activities, the bridge may be removed.

Under this alternative, a section of the South Fork of Lost Creek Road would be relocated approximately 200 feet north to move the road from the SMZ of South Fork Lost Creek. Approximately 2 miles of the existing road would be obliterated. A portion of the existing road, which is not located within the SMZ, would remain open to allow continued access to an existing campsite.

Six older stream crossings are in various stages of collapse and would be rehabilitated under this project proposal. Two crossings are in section 25, $\mathrm{T} 24 \mathrm{~N}, \mathrm{R} 17 \mathrm{~W}$. One of these crossings was originally constructed with logs and covered with dirt; the other only has crib logs, which would be removed. The remaining sites are located in Sections 2, 4, 18, and 20, T24N, R17W; crib logs and, in some instances, stringers and bridge planking would be removed. Streambanks would be stabilized at these locations as part of the rehabilitation. 


\section{ACTION ALTERNATIVE C}

The primary objective of this alternative is to provide a greater return to the trust beneficiaries by limiting development costs. This alternative would harvest the proposed stands more intensely and utilize ground-based operations. The stands were selected based on their accessibility and proximity to each other. Approximately 22.7 mmbf would be harvested from an estimated 1,787 acres. The 4 silvicultural prescriptions proposed under this alternative are listed under Timber-Management Activities. More detailed descriptions of the silvicultural prescriptions, including photographs, are presented under Silvicultural Treatments and TABLE II-1 - HARVEST SYSTEM AND SILVICULTURAL AND POSTHARVEST TREATMENTS FOR ACTION ALTERNATIVES $B, C, D, A N D E$. A description of the road construction to be implemented under this proposed alternative is provided under Roadwork Activities. FIGURE II-2 - STANDS PROPOSED FOR HARVESTING WITH ACTION ALTERNATIVE $C$ is provided for reference following Road Activities.

\section{- Timber-Management Activities}

Action Alternative C proposes to harvest timber by utilizing 4 types of silvicultural methods:

$\begin{array}{ll}\text { Commercial thin } & 532 \text { acres } \\ \text { Shelterwood } & 676 \text { acres } \\ \text { Seedtree with } & \\ \text { reserves } & 481 \text { acres } \\ \text { Seedtree } & 98 \text { acres }\end{array}$

Old growth would be harvested from 1,122 acres. Of the 1,122 acres, 656 acres would continue to be classified as old growth, while the remaining 466 acres would no longer meet the oldgrowth definition. Due to the varied terrain, the proposed units would be harvested by helicopter, conventional ground- based equipment, and skyline

cable systems. Postharvest treatments would include piling slash, scarifying where needed, and, in some cases, broadcast burning. These activities would prepare the sites for the planting of western larch, western white pine, and ponderosa pine seedlings.

\section{- Roadwork Activities}

Approximately 45 miles of existing roads accessing the harvest area would require various levels of improvements and maintenance. Approximately 3.5 miles of road reconstruction, 12 miles of new road construction, and 7 miles of temporary road construction would be needed to access the harvest units. Two miles of existing road would be obliterated. All road segments would be used for administrative and logging purposes. Some of the roads are open year-round to all users. Following logging and site-preparation operations, grass seed would be distributed on the roads to stabilize the roadbeds and prevent erosion and weed establishment.

This proposal would improve a bridge crossing on soup Creek. The old bridge would be removed and the site would be upgraded to fit a temporary bridge that would provide access for

harvesting activities. Following postharvest activities, the bridge may be removed.

Under this alternative, a section of the South Fork Lost Creek Road would be relocated approximately 200 feet north to move the road from the SMZ of South Fork Lost Creek. Approximately 2 miles of the existing road would be obliterated. A portion of the existing road, which is not located in the SMZ, would remain 


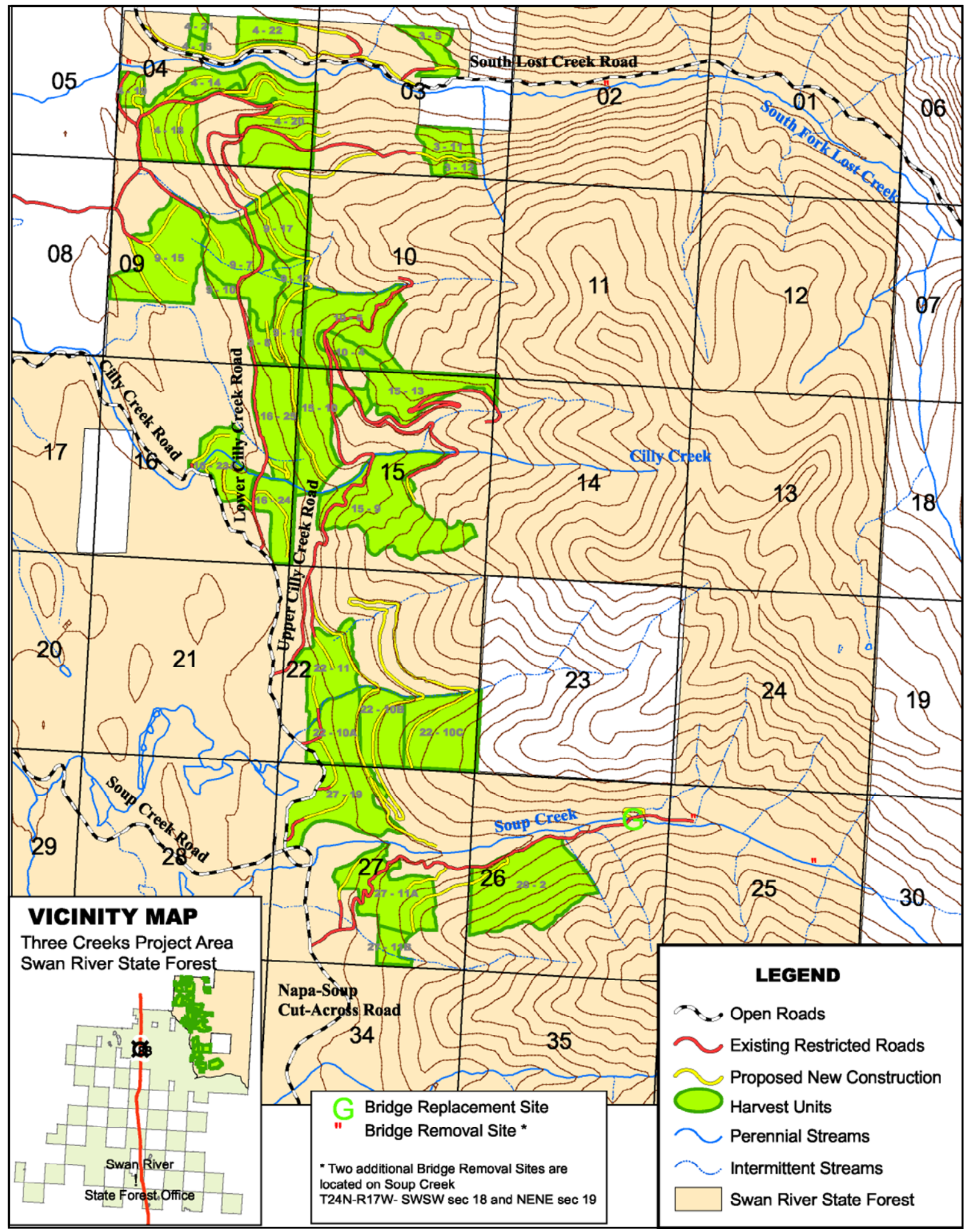


open to allow continued access to an existing campsite.

Six older stream crossings are in various stages of collapse and would be rehabilitated under this project proposal. Two crossings are in section 25, $\mathrm{T} 24 \mathrm{~N}, \mathrm{R} 17 \mathrm{~W}$. One of these crossings was originally constructed with logs and covered with dirt; the other only has crib logs, which would be removed. The remaining sites are located in sections 2, 4, 18, and 20, T24N, R17W; crib logs and, in some instances, stringers and bridge planking, would be removed. Streambanks would be stabilized at these locations as part of the rehabilitation.

\section{ACTION ALTERNATIVE D}

The primary objective of this alternative is to develop infrastructure by providing access while maintaining practical and economical timber sales. This alternative would build, reconstruct, and perform maintenance on the most amount of roads. Access would be provided into areas previously unroaded to allow for management activities for this timber sale proposal, but would also provide for future management needs. Additionally, areas could be accessed for firesuppression efforts.

Approximately $25.8 \mathrm{mmbf}$ would be harvested from an estimated 1,970 acres. The 4 silvicultural prescriptions proposed under this alternative are listed under Timber-Management Activities. More detailed descriptions of silvicultural prescriptions, including photographs, are presented under Silvicultural Treatments and TABLE II-1 HARVEST SYSTEM, SILVICULTURAL, AND POSTHARVEST TREATMENTS FOR ACTION ALTERNATIVES B, C, D, AND E. A description of road construction to be implemented under this proposed alternative is provided under Roadwork Activities. FIGURE II-3 - STANDS PROPOSED FOR HARVESTING WITH ACTION ALTERNATIVE $D$ is included for reference following Roadwork Activities.

\section{- Timber-Management Activities}

Action Alternative $D$ proposes to harvest timber by utilizing 4 types of silvicultural methods:

$\begin{array}{ll}\text { Commercial thin } & 560 \text { acres } \\ \text { Shelterwood } & 623 \text { acres } \\ \text { Seedtree with } & 615 \text { acres } \\ \text { reserves } & \\ \text { Seedtree } & 172 \text { acres }\end{array}$

This alternative would harvest in 1,143 acres of old growth. of the 1,143 acres, 547 would continue to be classified as old growth, while the remaining 596 
FIGURE II-3 - STANDS PROPOSED FOR HARVESTING WITH ACTION ALTERNATIVE D

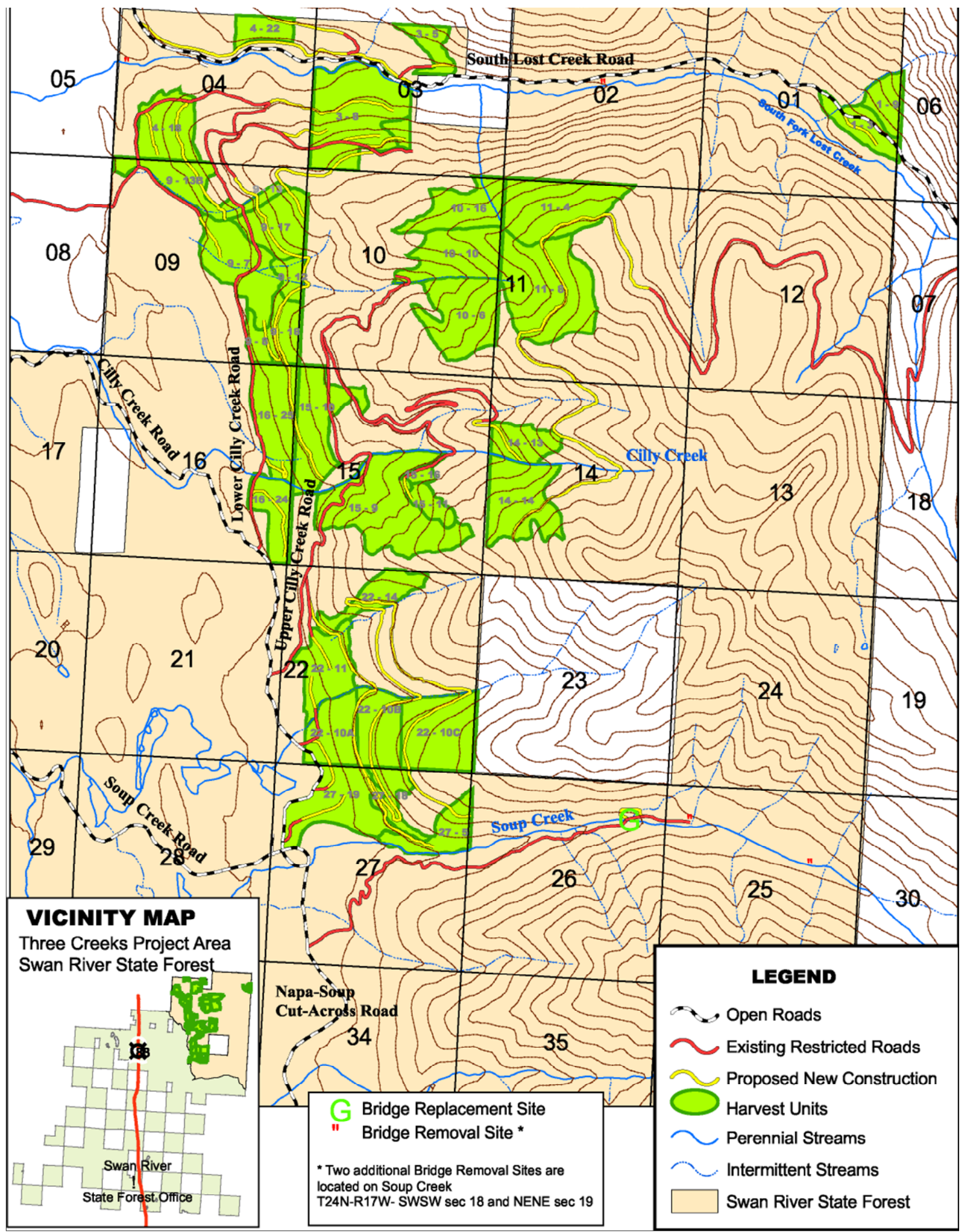


acres would no longer meet the old-growth definition. Due to varied terrain, the proposed units would be harvested by helicopter, conventional groundbased equipment, and skyline cable systems. Postharvest treatments would include piling slash, scarifying where needed, and, in some cases, broadcast burning. These activities would prepare the sites for the planting of western larch, western white pine, and ponderosa pine seedlings.

\section{- Roadwork Activities}

Approximately 53 miles of existing roads accessing the harvest area would require various levels of improvements and maintenance. Approximately 6 miles of road reconstruction, 16 miles of new road construction, and 4.5 miles of temporary road construction would be needed to access the harvest units. Two miles of existing road would be obliterated. All road segments would be used for administrative and logging purposes. Some of the roads are open year-round to all users. Following logging and site-preparation operations, grass seed would be distributed on the roads to stabilize the roadbeds and prevent erosion and weed establishment.

This proposal would improve a bridge crossing on soup Creek. The old bridge would be removed and the site would be upgraded to fit a temporary bridge that would provide access for harvesting activities. Following postharvest activities, the bridge may be removed.

Under this alternative, a section of the South Fork of Lost Creek Road would be relocated approximately 200 feet north to move the road from the SMZ of South Fork Lost Creek.
Approximately 2 miles of the existing road would be obliterated. A portion of the existing road, which is not located in the SMZ, would remain open to allow continued access to an existing campsite.

Six older stream crossings are in various stages of collapse and would be rehabilitated under this project proposal. Two crossings are in section 25, T24N, R17W. One of these crossings was originally constructed with logs and covered with dirt; the other only has the crib logs, which would be removed. The remaining sites are located in sections 2, 4, 18, and 20, T24N, R17W; crib logs and, in some instances, stringers and bridge planking would be removed. The streambanks would be stabilized at these locations as part of the rehabilitation. 


\section{ᄀ ACTION ALTERNATIVE E}

This alternative was developed to incorporate components of an alternative suggested by members of the public, specifically to reduce the amount of harvesting in old-growth areas and minimize road building. For this alternative, several sawtimber-size timber stands that did not meet the oldgrowth definition were selected for harvesting. Old-growth stands included in this alternative have the highest levels of insect and disease mortality occurring. This alternative also minimizes road building by requiring more stands to utilize helicopter operations. Approximately $24.0 \mathrm{mmbf}$ would be harvested from an estimated 1,999 acres. The 4 silvicultural prescriptions proposed under this alternative are listed under Timber-Management Activities. More detailed descriptions of silvicultural prescriptions, including photographs, are presented under Silvicultural Treatments and TABLE II-1 HARVEST SYSTEMS AND SILVICULTURAL AND POSTHARVEST TREATMENTS FOR ACTION ALTERNATIVES B, C, D, AND $E$. A description of the road construction to be implemented under this proposed alternative is provided under Roadwork

Activities. FIGURE II-4 - STANDS PROPOSED FOR HARVESTING WITH ACTION ALTERNATIVE $E$ is included for reference following Roadwork Activities.

\section{- Timber-Management Activities}

Action Alternative E proposes to harvest timber by utilizing 4 types of silvicultural methods:

$\begin{array}{ll}\text { Commercial thin } & 684 \text { acres } \\ \text { Shelterwood } & 605 \text { acres } \\ \text { Seedtree with } & \\ \text { reserves } & 575 \text { acres } \\ \text { Seedtree } & 135 \text { acres }\end{array}$

This alternative would harvest in 446 acres of old growth. Of the 446 acres, 99 acres would continue to be classified as old growth, while the remaining 347 acres would no longer meet the old-growth definition. Due to the varied terrain, the proposed units would be harvested by helicopter, conventional groundbased equipment, and skyline cable systems. Postharvest treatments would include piling slash, scarifying where needed, and, in some cases, broadcast burning. These activities would prepare the sites for the planting of western larch, western white pine, and ponderosa pine seedlings.

\section{- Roadwork Activities}

Approximately 56 miles of existing roads accessing the harvest area would require various levels of improvements and maintenance. Approximately 6 miles of road reconstruction, 7.5 miles of new road construction, and 3 miles of temporary road construction would be needed to access the harvest units. Two miles of existing road would be obliterated. All road segments would be used for administrative and logging purposes. Some of the roads are open year-round to all users. Following logging and site-preparation operations, grass seed would be distributed on the roads to stabilize the roadbeds and prevent erosion and weed establishment.

This proposal would improve a bridge crossing on soup Creek. The old bridge would be removed and the site would be upgraded to fit a temporary bridge that would provide access for harvesting activities. Following postharvest activities, the bridge may be removed.

Under this alternative, a section of the South Fork Lost Creek Road would be relocated 
FIGURE II-4 - STANDS PROPOSED FOR HARVESTING WITH ACTION ALTERNATIVE E

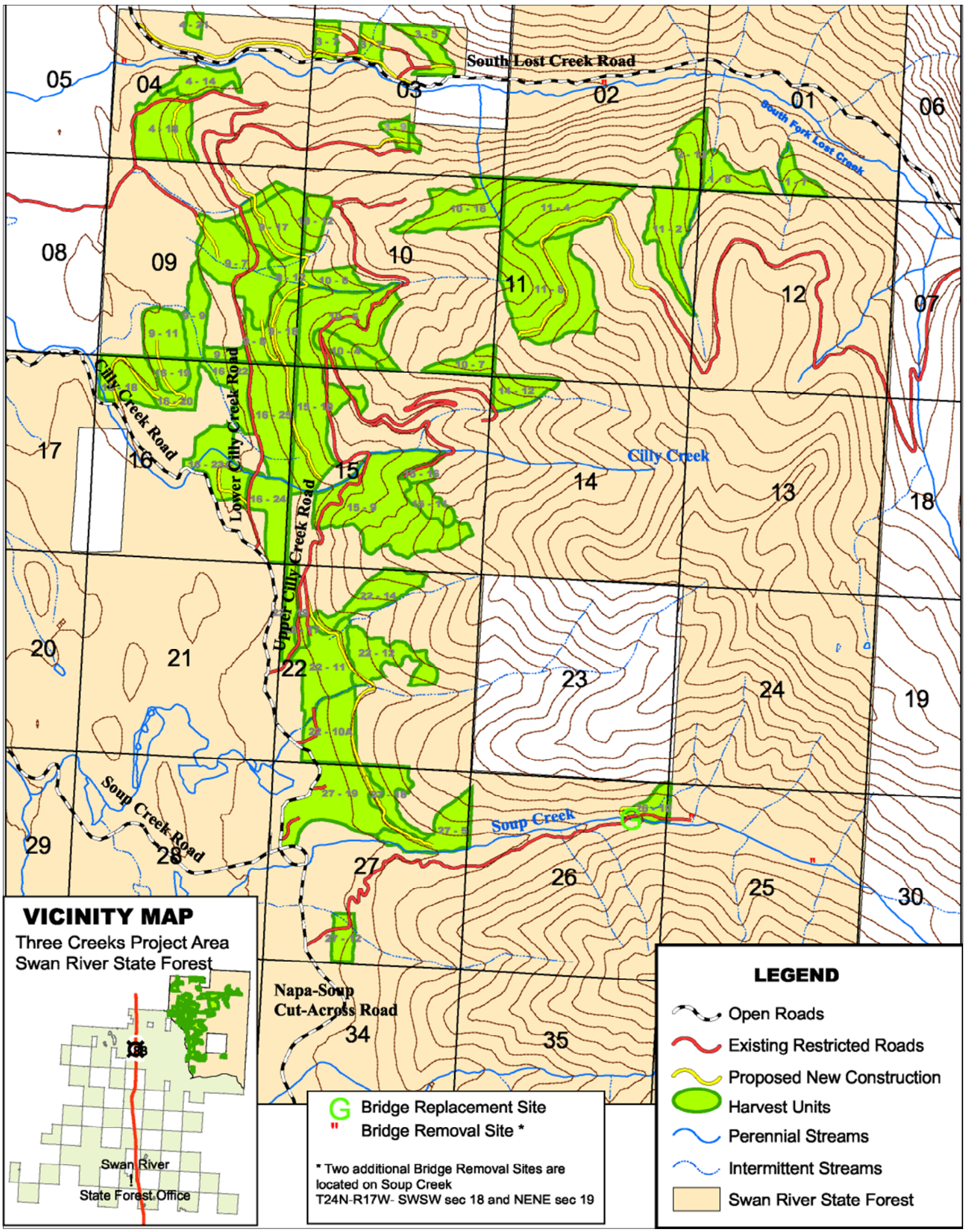


approximately 200 feet north to move the road from the SMZ of South Fork Lost Creek. Approximately 2 miles of the existing road would be obliterated. A portion of the existing road, which is not located within the SMZ, would remain open to allow continued access to an existing campsite.

Six older stream crossings are in various stages of collapse and would be rehabilitated under this project proposal. Two crossings are in section 25,
T24N, R17W. One of these crossings was originally constructed with logs and covered with dirt; the other only has crib logs, which would be removed. The remaining sites are located in Sections 2, 4, 18, and 20, T24N, R17W; crib logs and, in some instances, stringers and bridge planking would be removed. Streambanks would be stabilized at these locations as part of the rehabilitation.

\begin{tabular}{|c|c|c|c|c|c|}
\hline \multirow{3}{*}{$\begin{array}{c}\text { OLD-GROWTH } \\
\text { TYPE }\end{array}$} & \multirow{3}{*}{$\begin{array}{c}\text { OLD-GROWTH } \\
\text { ACRES }\end{array}$} & \multicolumn{4}{|c|}{ POSTHARVEST } \\
\hline & & \multicolumn{4}{|c|}{ ACTION ALTERNATIVE } \\
\hline & & B & $\mathbf{C}$ & D & $\mathbf{E}$ \\
\hline Douglas-fir & 8 & 8 & 8 & 8 & 8 \\
\hline Western larch/Douglas-fir & 1,830 & 1,968 & 1,901 & 1,960 & 1,710 \\
\hline Western white pine & 2,016 & 2,016 & 2,016 & 2,016 & 2,016 \\
\hline Mixed conifer & 6,926 & 6,253 & 6,397 & 6,200 & 6,699 \\
\hline Subalpine fir & 1,114 & 1,114 & 1,114 & 1,114 & 1,114 \\
\hline Lodgepole pine & 0 & 0 & 0 & 0 & 0 \\
\hline Ponderosa pine & 584 & 584 & 584 & 584 & 584 \\
\hline Totals & 12,478 & 11,943 & 12,020 & 11,882 & 12,131 \\
\hline
\end{tabular}




\section{PROPOSED SILVICULTURAL TREATMENTS}

Four silvicultural prescriptions (harvest treatments) were chosen to meet the management objectives of this project. The photographs provide a visual representation of how these treated areas may appear following harvesting activities. Due to the variations in stand age, species components, and natural openings, the visualizations show what would be expected to occur on the ground.

\section{- COMMERCIAL THIN HARVEST}

Forty-five to fifty percent of the existing overstory would be harvested to reduce stocking density, improve growth rates and vigor, and increase the representation of primarily western larch and Douglas-fir in the stand. The stand would be fully stocked with trees, but would have an open-canopied appearance following harvesting. The estimated overall stocking of trees would be 80 to 110 trees per acre.

\section{- SHELTERWOOD HARVEST}

The majority of the trees within these stands would be removed. Stand density remaining on the site would be 12 to 16 trees per acre. The remaining canopy would provide shade for the planted seedlings and those that regenerate naturally. In addition to the planted seedlings, the retained overstory would provide a seed source. Leave trees would primarily consist of western larch, ponderosa pine (where available), and Douglas-fir that are healthy and would not exhibit a risk to bark beetle infestation. In addition to retained live trees, 2 snags per acre and 2 snag recruits per acre 21 inches diameter at breast height (dbh) or greater would be retained. Snagrecruitment trees differ from leave trees by exhibiting signs of defect (ie. heart rot, broken tops, crown loss).

\section{- SEEDTREE WITH RESERVES HARVEST}

Most trees would be harvested with the exception of 6 to 8 trees per acre that would be retained for a seed source. Leave trees would consist of western larch, ponderosa pine (where available), Douglas-fir, and, in some instances, clumps of western red cedar. Seedtrees would be selected for their overall crown health and ability to produce cones for a seed source to regenerate the site. In addition to the live leave trees, 2 snags per acre and 2 snag recruits per acre 21 inches dbh or greater would be retained. Snagrecruitment trees differ from leave trees by exhibiting signs of defect (ie. heart rot, broken tops, crown loss). The reserves for these stands would be approximately 1.7 to 3 acres in size and would be placed within the units. The reserves would not be harvested even in part, but would be left in the existing condition. The purpose for the reserves is to maintain compliance with the SVGBCA, which requires no more than 600 feet between hiding cover.

\section{- SEEDTREE HARVEST}

Most trees would be harvested with the exception of 6 to 8 trees per acre that would be retained for a seed source. Leave trees would consist of western larch, ponderosa pine (where available), Douglas-fir, and, in some instances, clumps of western red cedar. Seedtrees would be selected for their overall crown health and ability to produce cones for a seed source to regenerate the site. In addition to the live leave trees, 2 snags per acre and 2 snag recruits per acre 21 inches dbh or greater would be retained. Snagrecruitment trees differ from leave trees by exhibiting signs of defect (ie. heart rot, broken tops, crown loss). 


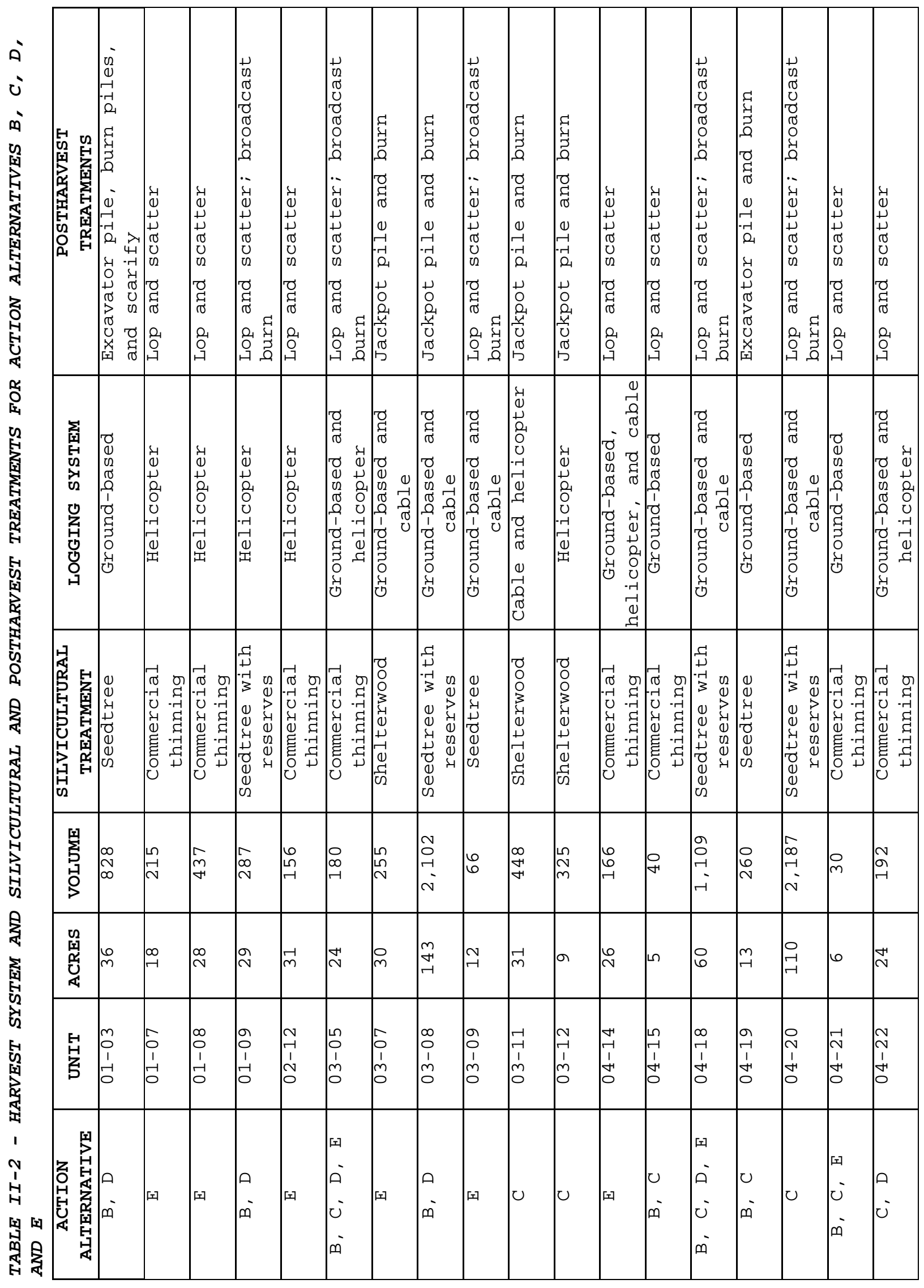

Page II-14

Three Creeks Timber Sale Project DEIS 


\begin{tabular}{|c|c|c|c|c|c|c|c|c|c|c|c|c|c|c|c|c|}
\hline 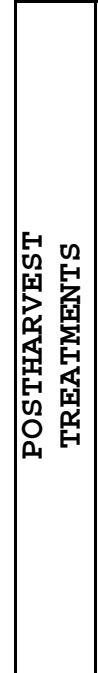 & 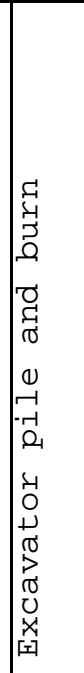 & 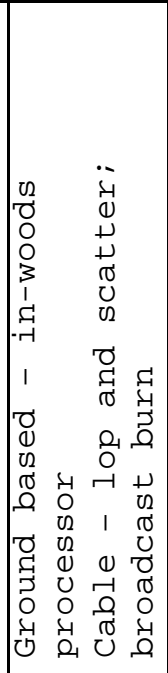 & 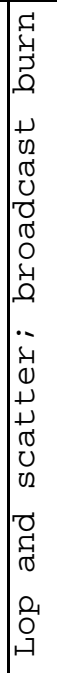 & 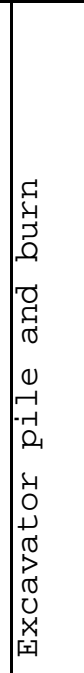 & 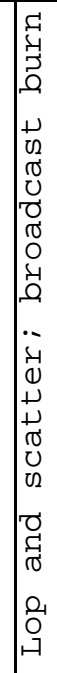 & 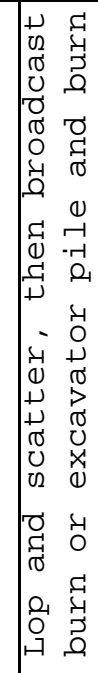 & 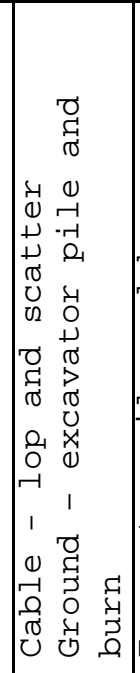 & 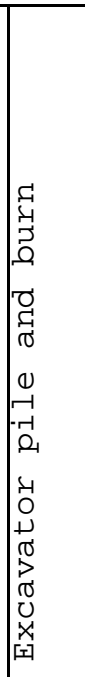 & 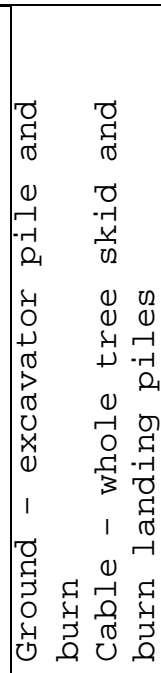 & 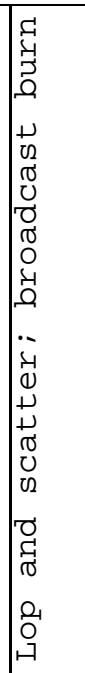 & 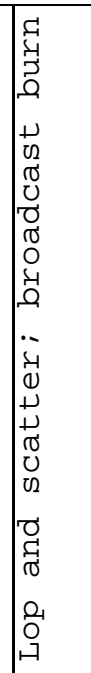 & 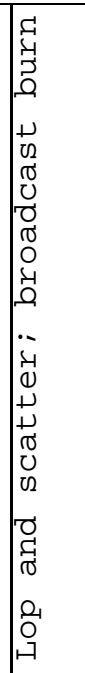 & 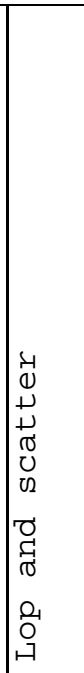 & 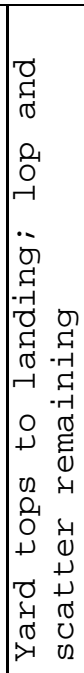 & 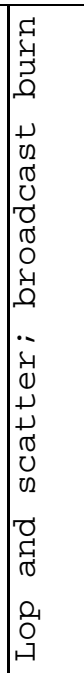 & 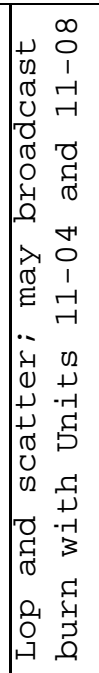 \\
\hline 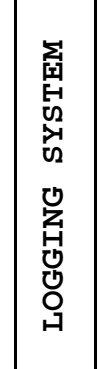 & $\begin{array}{l}0 \\
0 \\
0 \\
0 \\
0 \\
0 \\
0 \\
1 \\
0 \\
0 \\
9 \\
0 \\
0 \\
4 \\
0\end{array}$ & $\begin{array}{ll}0 & \\
0 & \\
0 & \\
0 & \\
0 & \\
0 & 0 \\
0 & 0 \\
0 & 1 \\
0 & 0 \\
0 & 0 \\
1 & 0 \\
0 & 0 \\
0 & \\
5 \\
0 \\
0 \\
4 \\
0\end{array}$ & $\begin{array}{l}0 \\
-1 \\
0 \\
0 \\
0 \\
0\end{array}$ & $\begin{array}{l}0 \\
0 \\
0 \\
0 \\
0 \\
0 \\
0 \\
1 \\
0 \\
0 \\
5 \\
0 \\
0 \\
y \\
0\end{array}$ & $\begin{array}{l}0 \\
0 \\
0 \\
0 \\
0 \\
0 \\
0\end{array}$ & $\begin{array}{ll}0 & 0 \\
0 & \\
0 \\
0 \\
0 \\
0 \\
0 \\
0 & 0 \\
0 & -1 \\
0 & 0 \\
0 & 0 \\
1 & 0 \\
0 & 0 \\
0 & 0 \\
0 & \\
0 \\
0 \\
y \\
0 \\
0\end{array}$ & 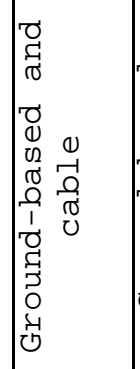 & $\begin{array}{l}0 \\
0 \\
0 \\
0 \\
0 \\
0 \\
1 \\
0 \\
0 \\
5 \\
0 \\
0 \\
4 \\
0\end{array}$ & 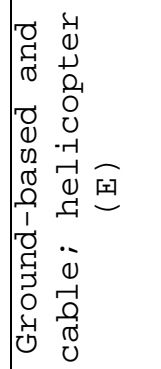 & $\begin{array}{ll}0 & 0 \\
0 & \\
0 & \\
0 & \\
0 & \\
0 & 0 \\
0 & 0 \\
0 & -1 \\
0 & 0 \\
0 & 0 \\
1 & 0 \\
0 & 0 \\
0 & 0 \\
2 & \\
0 \\
0 \\
0 \\
0\end{array}$ & 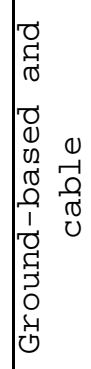 & $\begin{array}{ll}0 & 0 \\
0 & \\
0 & \\
0 & \\
0 & \\
0 & 0 \\
0 & 0 \\
0 & -1 \\
0 & 0 \\
0 & 0 \\
1 & 0 \\
0 & 0 \\
0 & 0 \\
0 & \\
0 \\
0 \\
0 \\
0 & \end{array}$ & 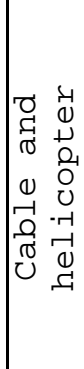 & $\begin{array}{l}0 \\
0 \\
0 \\
+ \\
0 \\
0 \\
0 \\
0 \\
-1 \\
-1 \\
0 \\
0 \\
-1\end{array}$ & $\begin{array}{ll}0 & 0 \\
0 & \\
0 & \\
0 & \\
0 & \\
0 & 0 \\
0 & 0 \\
0 & -1 \\
0 & 0 \\
0 & 0 \\
1 & 0 \\
0 & 0 \\
0 & 0 \\
2 & \\
0 \\
0 \\
0 \\
0\end{array}$ & 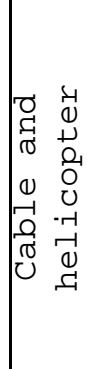 \\
\hline 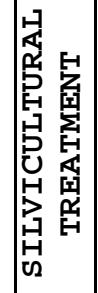 & 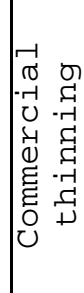 & 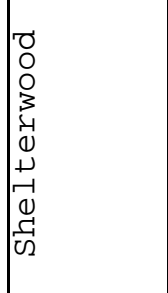 & \begin{tabular}{l}
0 \\
0 \\
0 \\
0 \\
3 \\
4 \\
0 \\
0 \\
\pm \\
-1 \\
0 \\
\multicolumn{1}{|c}{} \\
$\omega 2$
\end{tabular} & 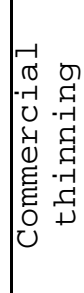 & $\begin{array}{l}0 \\
0 \\
0 \\
-4 \\
y \\
0 \\
0 \\
0 \\
0 \\
02\end{array}$ & $\begin{array}{l}0 \\
0 \\
0 \\
y \\
y \\
y \\
0 \\
0 \\
0 \\
02 \\
02\end{array}$ & 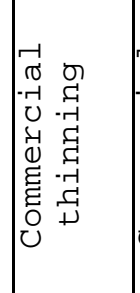 & 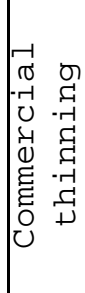 & $\begin{array}{l}0 \\
0 \\
0 \\
0 \\
3 \\
-1 \\
0 \\
0 \\
+1 \\
-1 \\
0 \\
0 \\
01 \\
02\end{array}$ & $\begin{array}{l}0 \\
0 \\
0 \\
\nu \\
y \\
1 \\
0 \\
0 \\
0 \\
0 \\
\nu\end{array}$ & 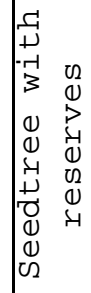 & $\begin{array}{cc}-1 & \\
1 & \\
--1 & \\
--1 & 0 \\
3 & 0 \\
0 & 0 \\
0 & 2 \\
0 & 0 \\
-1 & 0 \\
1 & 0 \\
0 & 0 \\
0 & -4 \\
0 & \\
0 & \end{array}$ & 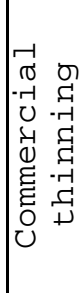 & $\begin{array}{l}0 \\
0 \\
0 \\
0 \\
3 \\
3 \\
0 \\
0 \\
+1 \\
-1 \\
0 \\
0 \\
0 \\
0\end{array}$ & 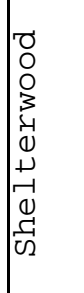 & $\begin{array}{l}0 \\
0 \\
0 \\
0 \\
3 \\
4 \\
0 \\
0 \\
\pm \\
-1 \\
0 \\
0 \\
-1 \\
\omega 2\end{array}$ \\
\hline 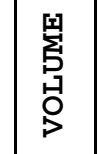 & ${ }_{\infty}^{m}$ & $\begin{array}{l}\overrightarrow{1} \\
0 \\
0 \\
-i\end{array}$ & $\mid \begin{array}{l}-1 \\
m \\
r\end{array}$ & $\mid \begin{array}{l}0 \\
6 \\
-1\end{array}$ & 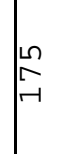 & 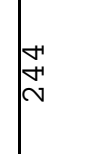 & $\mid \begin{array}{l}\infty \\
\nexists \\
-1\end{array}$ & $\begin{array}{l}-1 \\
0 \\
0\end{array}$ & $\begin{array}{l}\hat{m} \\
m \\
\sigma\end{array}$ & 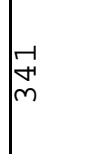 & $\frac{N}{N}$ & $\begin{array}{l}\hat{\sigma} \\
0 \\
\sigma\end{array}$ & $\begin{array}{l}n \\
m \\
m\end{array}$ & $\begin{array}{l}0 \\
6 \\
-1\end{array}$ & $\begin{array}{l}- \\
- \\
-\end{array}$ & \begin{tabular}{l}
-1 \\
\hdashline \\
$\infty$
\end{tabular} \\
\hline 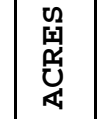 & の & $\left.\right|_{\infty}$ & 㭊 & $\stackrel{\infty}{\infty}$ & $\infty$ & $\stackrel{N}{m}$ & $\mid \begin{array}{l}\curvearrowright \\
-1\end{array}$ & $\begin{array}{l}\infty \\
0 \\
0 \\
-1\end{array}$ & 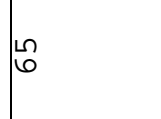 & m & $\underset{-1}{\curvearrowleft}$ & in & $\begin{array}{l}\infty \\
\infty\end{array}$ & $\mid \begin{array}{l}\sigma \\
-1\end{array}$ & $\stackrel{-}{\sim}$ & I \\
\hline $\begin{array}{l}\text { 龺 } \\
\text { 点 }\end{array}$ & $\begin{array}{l}0 \\
0 \\
1 \\
1 \\
0 \\
0\end{array}$ & $\begin{array}{l}\hat{n} \\
0 \\
1 \\
0 \\
0\end{array}$ & $\begin{array}{l}\infty \\
0 \\
1 \\
2 \\
0\end{array}$ & $\begin{array}{l}0 \\
0 \\
1 \\
1 \\
0 \\
0\end{array}$ & $\begin{array}{l}0 \\
0 \\
1 \\
1 \\
2 \\
0\end{array}$ & $\mid \begin{array}{l}-1 \\
-1 \\
1 \\
a \\
0 \\
0\end{array}$ & $\begin{array}{l}2 \\
-1 \\
1 \\
2 \\
0\end{array}$ & $\begin{array}{l}n \\
1 \\
1 \\
0 \\
0 \\
0\end{array}$ & $\begin{array}{l}r \\
1 \\
1 \\
0 \\
0\end{array}$ & $\begin{array}{l}\infty \\
-1 \\
1 \\
0 \\
0\end{array}$ & $\mid \begin{array}{l}+1 \\
0 \\
1 \\
0 \\
r-1\end{array}$ & $\begin{array}{l}n \\
0 \\
1 \\
0 \\
r \\
r-1\end{array}$ & $\begin{array}{l}0 \\
0 \\
0 \\
1 \\
0 \\
-1\end{array}$ & $\begin{array}{l}r \\
0 \\
1 \\
0 \\
r-1\end{array}$ & $\begin{array}{l}\infty \\
0 \\
1 \\
0 \\
-1 \\
-1\end{array}$ & $\begin{array}{l}0 \\
0 \\
-1 \\
1 \\
0 \\
r-1\end{array}$ \\
\hline 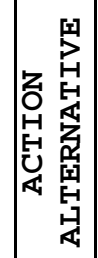 & 되 & نं & $\begin{array}{l}\text { à } \\
\dot{0} \\
\dot{0}\end{array}$ & |되 & ضे & 되 & à & ๓) & 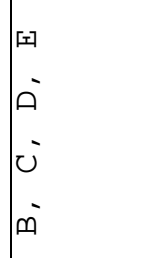 & 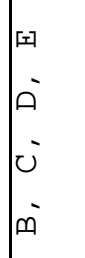 & ضे & ن' & $\varnothing$ & |되 & |되 & ○ \\
\hline
\end{tabular}




\begin{tabular}{|c|c|c|c|c|c|c|c|c|c|c|c|c|c|c|c|c|c|c|}
\hline 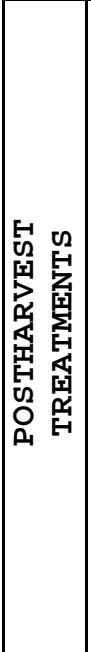 & 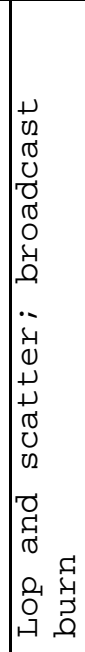 & 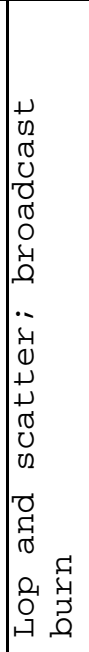 & $\begin{array}{l}4 \\
0 \\
1 \\
1 \\
0 \\
0 \\
0 \\
0 \\
0 \\
0 \\
0 \\
0 \\
0 \\
01 \\
0 \\
1 \\
1\end{array}$ & 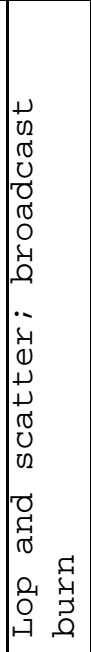 & 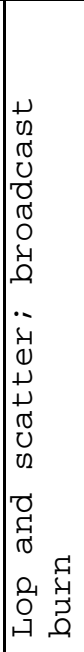 & 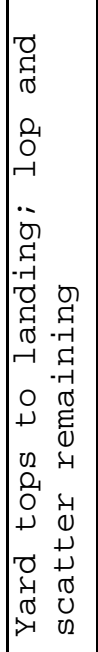 & 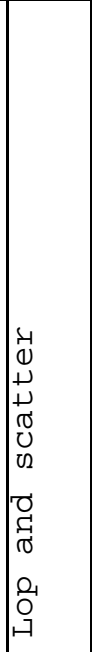 & 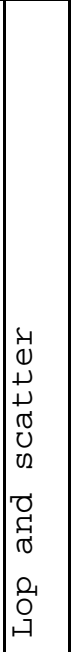 & 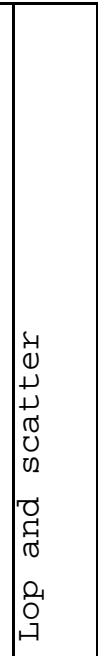 & 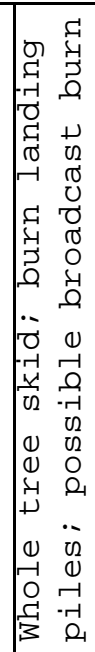 & 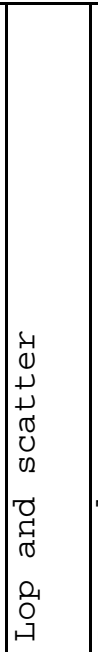 & $\begin{array}{l}1 \\
0 \\
0 \\
+ \\
+ \\
0 \\
0 \\
0 \\
0 \\
0 \\
0 \\
0 \\
0 \\
0 \\
0 \\
0 \\
1 \\
1\end{array}$ & 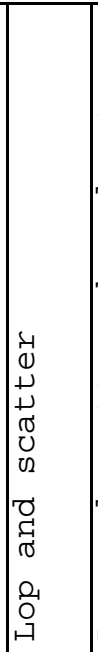 & 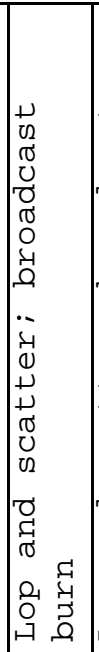 & 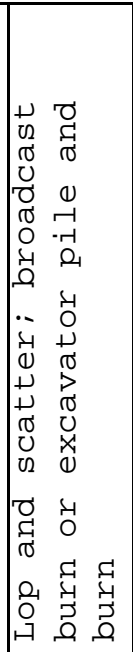 & 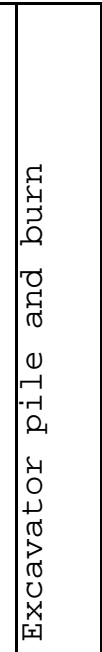 & 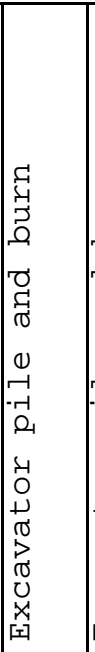 & 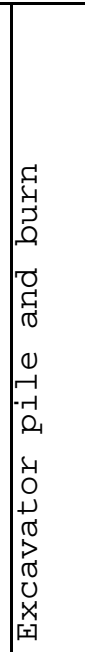 \\
\hline 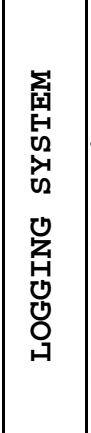 & 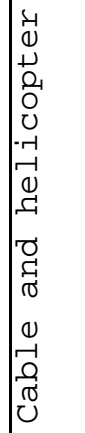 & $\begin{array}{l}4 \\
0 \\
0 \\
+ \\
0 \\
0 \\
0 \\
0 \\
-1 \\
-1 \\
01 \\
0 \\
-1\end{array}$ & 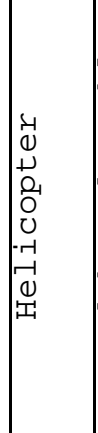 & 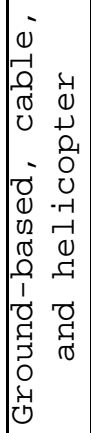 & 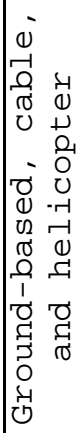 & $\begin{array}{l}-1 \\
0 \\
+ \\
0 \\
0 \\
0 \\
0 \\
0 \\
-1 \\
-1 \\
0 \\
0 \\
ن\end{array}$ & $\begin{array}{l}0 \\
-1 \\
0 \\
0 \\
0 \\
0\end{array}$ & \begin{tabular}{|l}
0 \\
0 \\
-1 \\
0 \\
$\pi$ \\
0 \\
0
\end{tabular} & $\begin{array}{cc}0 & \\
-1 & \\
0 & 4 \\
\pi & 0 \\
0 & 0 \\
0 & 0 \\
0 & 0 \\
0 & 0 \\
0 & 0 \\
0 & -1 \\
0 & 0 \\
0 & 0 \\
0 & -1 \\
1 & -1 \\
0 & 0 \\
0 & \Xi \\
0 & 0 \\
0 & 0 \\
4 & \end{array}$ & $\begin{array}{ll} & \\
0 & \\
0 & \\
0 & \\
0 & \\
0 & \\
0 & 0 \\
0 & 0 \\
0 & -1 \\
0 & 0 \\
0 & 0 \\
1 & 0 \\
0 & 0 \\
0 & \\
0 & \\
0 & \\
0 & \\
0 & \end{array}$ & 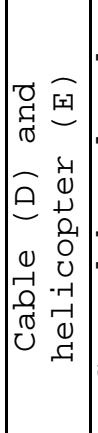 & 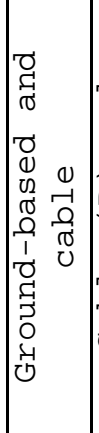 & 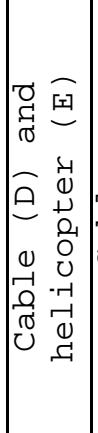 & $\begin{array}{l}0 \\
0 \\
0 \\
0 \\
0 \\
0 \\
0\end{array}$ & $\begin{array}{l}0 \\
0 \\
0 \\
0 \\
0 \\
0 \\
01 \\
1 \\
0 \\
0 \\
5 \\
0 \\
0 \\
0 \\
0\end{array}$ & 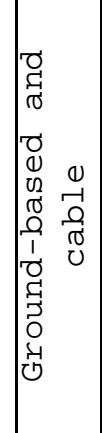 & \begin{tabular}{ll}
0 & \\
0 & \\
0 & 0 \\
0 & 0 \\
0 & -1 \\
0 & 0 \\
0 & 0 \\
1 & 0 \\
0 & 0 \\
$\vdots$ & 0 \\
0 & 0 \\
0 & \multicolumn{1}{|c}{} \\
0 & 0 \\
0 &
\end{tabular} & $\begin{array}{l}0 \\
0 \\
0 \\
0 \\
0 \\
0 \\
0 \\
1 \\
0 \\
0 \\
5 \\
0 \\
0 \\
y \\
0\end{array}$ \\
\hline 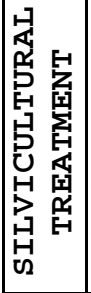 & $\begin{array}{l}0 \\
0 \\
0 \\
0 \\
3 \\
3 \\
4 \\
0 \\
+1 \\
-1 \\
0 \\
\frac{1}{1} \\
02\end{array}$ & $\begin{array}{l}0 \\
0 \\
0 \\
\nu \\
y \\
0 \\
0 \\
0 \\
0 \\
02 \\
02\end{array}$ & 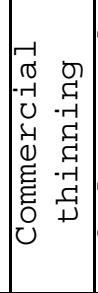 & 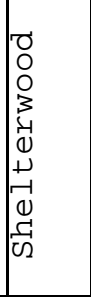 & 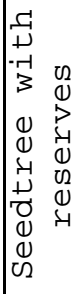 & 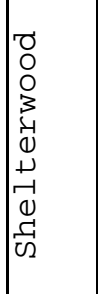 & 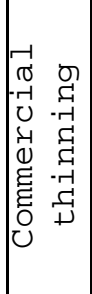 & \begin{tabular}{l}
0 \\
0 \\
0 \\
0 \\
3 \\
4 \\
0 \\
0 \\
+ \\
-1 \\
0 \\
\multicolumn{1}{|c}{} \\
2
\end{tabular} & 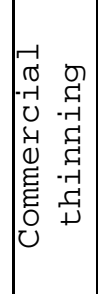 & $\mid \begin{array}{l}0 \\
0 \\
0 \\
0 \\
3 \\
4 \\
0 \\
0 \\
+ \\
-1 \\
0 \\
0 \\
-1 \\
02\end{array}$ & 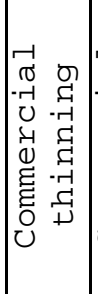 & 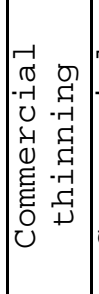 & 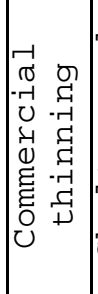 & $\begin{array}{l}0 \\
0 \\
0 \\
0 \\
3 \\
3 \\
0 \\
0 \\
1 \\
-1 \\
0 \\
0 \\
0 \\
0\end{array}$ & 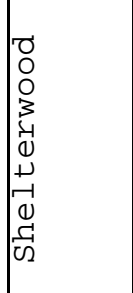 & 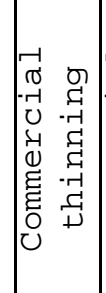 & 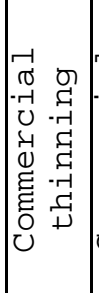 & 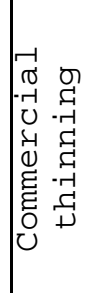 \\
\hline $\begin{array}{l}\text { 四 } \\
\text { 号 } \\
\text { ○ }\end{array}$ & 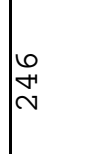 & $\begin{array}{l}-1 \\
\infty \\
\sigma\end{array}$ & 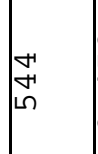 & $\begin{array}{l}n \\
n \\
\sigma \\
\dot{n} \\
n\end{array}$ & 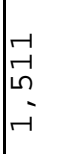 & $\begin{array}{l}0 \\
m \\
\sim\end{array}$ & $\begin{array}{l}0 \\
0 \\
m\end{array}$ & $\begin{array}{l}6 \\
\text { nn } \\
\sigma\end{array}$ & $\begin{array}{l}\hat{n} \\
r-1 \\
-i\end{array}$ & $\begin{array}{l}8 \\
0 \\
n \\
n\end{array}$ & $\begin{array}{l}\infty \\
-1\end{array}$ & 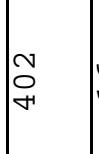 & $\begin{array}{l}6 \\
-1\end{array}$ & $\underset{\underset{\sigma}{N}}{\stackrel{N}{~}}$ & $\underset{⿱ 亠 䒑}{\stackrel{N}{m}}$ & ने & 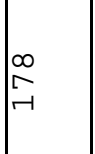 & $\begin{array}{l}\infty \\
\curvearrowright \\
\sim \\
N\end{array}$ \\
\hline 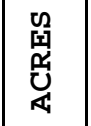 & $\begin{array}{l}\infty \\
r-1\end{array}$ & $\mid \begin{array}{l}\infty \\
n\end{array}$ & in & $\begin{array}{l}\infty \\
\sigma\end{array}$ & $\begin{array}{l}m \\
m \\
r\end{array}$ & $\stackrel{\sim}{\sim}$ & bo & $\begin{array}{l}m \\
\infty \\
\infty\end{array}$ & $\mid \begin{array}{l}6 \\
7 \\
-1\end{array}$ & $\left.\right|_{\infty} ^{\infty}$ & $\begin{array}{l}\infty \\
r-1\end{array}$ & 6 & $\infty$ & 6 & in & $\begin{array}{l}\infty \\
-1\end{array}$ & @ & $\stackrel{\infty}{\infty}$ \\
\hline $\begin{array}{l}\text { 旨 } \\
\text { 号 }\end{array}$ & $\begin{array}{l}\text { N } \\
\overrightarrow{1} \\
1 \\
0 \\
-1\end{array}$ & $\begin{array}{l}0 \\
0 \\
-1 \\
1 \\
0 \\
-1\end{array}$ & $\begin{array}{l}\text { N } \\
\text { O } \\
1 \\
-1 \\
-1\end{array}$ & $\begin{array}{l}\overrightarrow{1} \\
0 \\
1 \\
-1 \\
\overrightarrow{-1}\end{array}$ & $\begin{array}{l}\infty \\
0 \\
1 \\
1 \\
-1 \\
-1\end{array}$ & 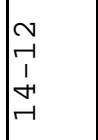 & $\begin{array}{l}m \\
m \\
-1 \\
1 \\
\forall \\
-1\end{array}$ & $\mid \begin{array}{l}\overrightarrow{1} \\
\overrightarrow{1} \\
\dot{a} \\
\vec{H} \\
\vec{H}\end{array}$ & $\begin{array}{l}0 \\
0 \\
1 \\
1 \\
-1 \\
-1\end{array}$ & $\begin{array}{l}0 \\
0 \\
1 \\
1 \\
\omega \\
-1\end{array}$ & 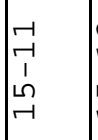 & 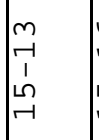 & $\begin{array}{l}6 \\
-1 \\
1 \\
\llcorner \\
-1 \\
-1\end{array}$ & 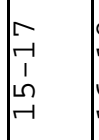 & $\begin{array}{l}\infty \\
-1 \\
1 \\
b \\
-1 \\
-1\end{array}$ & $\begin{array}{l}0 \\
-1 \\
1 \\
6 \\
-1\end{array}$ & $\begin{array}{l}0 \\
\stackrel{0}{0} \\
1 \\
6 \\
-1\end{array}$ & $\begin{array}{l}N \\
N \\
1 \\
6 \\
-1\end{array}$ \\
\hline 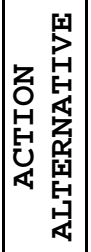 & & مَ & ك⿴囗十 & 国 & '되 & |r| & ه & D & ¿' & 0 & 回 & $\begin{array}{l}u \\
\dot{0}\end{array}$ & ¡' & ๓ & |r & | 15 & |되 & |r| \\
\hline
\end{tabular}

Page II-16

Three Creeks Timber Sale Project DEIS 


\begin{tabular}{|c|c|c|c|c|c|c|c|c|c|c|c|c|c|c|c|c|}
\hline 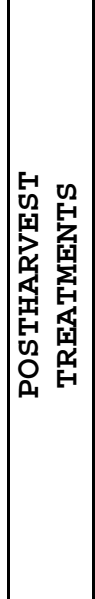 & 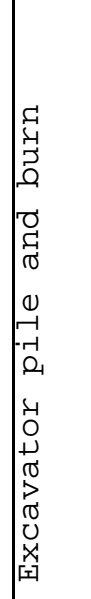 & 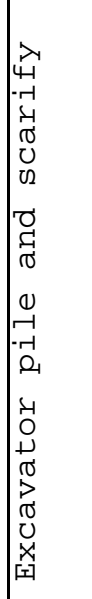 & 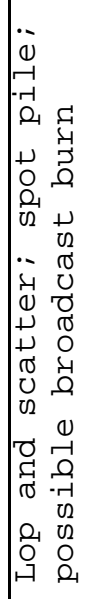 & 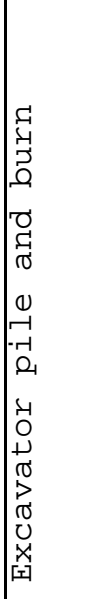 & 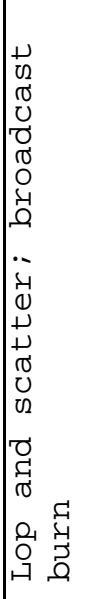 & $\begin{array}{l}4 \\
0 \\
1 \\
1 \\
0 \\
0 \\
0 \\
0 \\
0 \\
0 \\
0 \\
0 \\
0 \\
0 \\
0 \\
1 \\
1\end{array}$ & 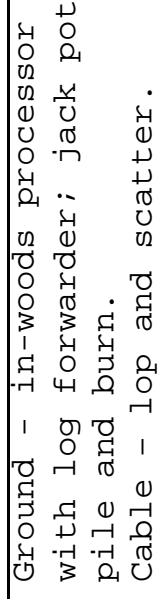 & $\begin{array}{l}4 \\
0 \\
0 \\
+ \\
+ \\
\sigma \\
0 \\
0 \\
0 \\
0 \\
0 \\
0 \\
\sigma \\
0 \\
0 \\
0 \\
0 \\
\ddots 1\end{array}$ & 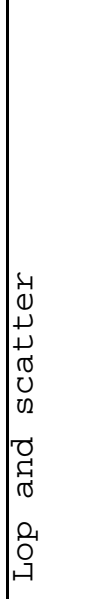 & 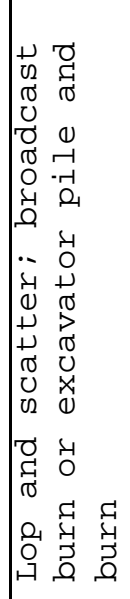 & 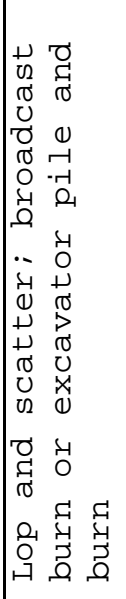 & 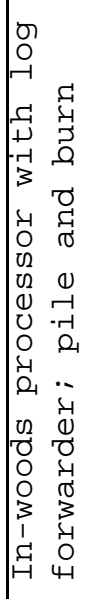 & 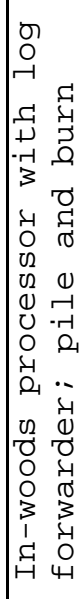 & 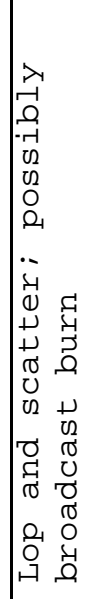 & 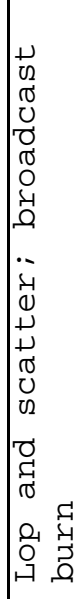 & $\begin{array}{l}4 \\
0 \\
1 \\
1 \\
0 \\
0 \\
0 \\
0 \\
0 \\
0 \\
0 \\
0 \\
0 \\
0 \\
0 \\
1 \\
1\end{array}$ \\
\hline 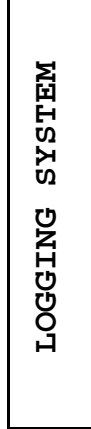 & \begin{tabular}{ll}
0 & \\
0 & 0 \\
0 & 0 \\
0 & 0 \\
0 & -1 \\
0 & 0 \\
1 & 0 \\
0 & 0 \\
0 & 0 \\
5 & 0 \\
0 & \multicolumn{1}{c}{} \\
0 & 0 \\
0 & 0
\end{tabular} & 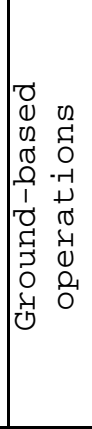 & $\begin{array}{ll}0 & \\
0 & 0 \\
0 & 0 \\
0 & 1 \\
0 & 1 \\
0 & 0 \\
0 & 0 \\
0 & 0 \\
0 & 0 \\
0 & 0 \\
0 & 0 \\
0 & 1 \\
4 & 0 \\
0 & \end{array}$ & $\begin{array}{ll}0 & \\
0 & \\
0 & 0 \\
0 & 0 \\
0 & 1 \\
0 & 0 \\
0 & 0 \\
1 & 0 \\
0 & 0 \\
\vdots & 0 \\
5 & 0 \\
0 & 0 \\
0 & 0 \\
0 & 0\end{array}$ & \begin{tabular}{|l}
0 \\
-1 \\
-1 \\
0 \\
0 \\
0 \\
0
\end{tabular} & 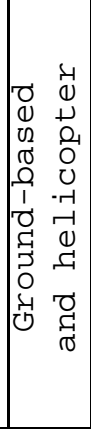 & 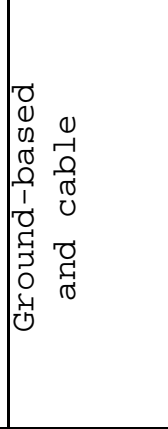 & 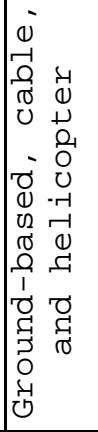 & $\begin{array}{l}0 \\
-1 \\
0 \\
0 \\
0 \\
0\end{array}$ & $\begin{array}{l}0 \\
0 \\
0 \\
0 \\
0 \\
0 \\
0 \\
1 \\
0 \\
0 \\
\vdots \\
0 \\
0 \\
y \\
0 \\
0\end{array}$ & $\begin{array}{ll}0 & \\
0 & \\
0 & 0 \\
0 & 0 \\
0 & -1 \\
0 & 0 \\
0 & 0 \\
0 & 0 \\
\vdots & 0 \\
5 & 0 \\
0 & 0 \\
0 & 0 \\
y & 0\end{array}$ & $\begin{array}{ll}0 & \\
0 & 0 \\
0 & 0 \\
0 & -1 \\
0 & 0 \\
0 & 0 \\
1 & 0 \\
0 & 0 \\
\vdots & 0 \\
5 & 0 \\
0 & 0 \\
0 & 0 \\
0 & 0\end{array}$ & $\begin{array}{ll}0 & 0 \\
0 & \\
0 & 0 \\
0 & \\
0 & \\
0 & 0 \\
0 & 0 \\
0 & -1 \\
0 & 0 \\
0 & 0 \\
1 & 0 \\
0 & 0 \\
0 & 0 \\
0 & \\
0 \\
0 \\
y \\
0\end{array}$ & \begin{tabular}{l}
4 \\
0 \\
0 \\
0 \\
0 \\
0 \\
0 \\
0 \\
-1 \\
-1 \\
0 \\
0 \\
\cline { 1 - 1 }
\end{tabular} & 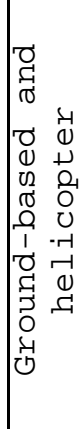 & 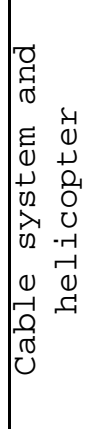 \\
\hline 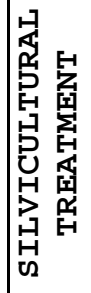 & 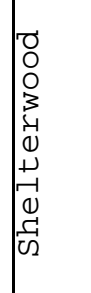 & $\begin{array}{l}0 \\
0 \\
0 \\
\nu \\
1 \\
0 \\
0 \\
0 \\
0 \\
02\end{array}$ & 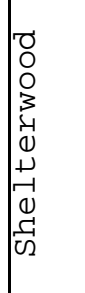 & 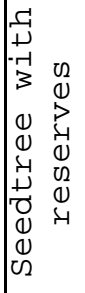 & $\begin{array}{l}0 \\
0 \\
0 \\
3 \\
3 \\
4 \\
0 \\
+ \\
-1 \\
0 \\
\frac{1}{\omega} \\
2\end{array}$ & 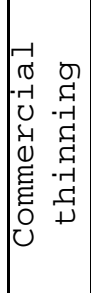 & $\begin{array}{ll} & \\
+ & \\
+ & \\
-1 & 0 \\
3 & 0 \\
0 & 0 \\
0 & 2 \\
0 & 4 \\
0 & 0 \\
4 & 0 \\
1 & 0 \\
0 & 0 \\
0 & 4 \\
0 & \\
0 & \\
0 & \end{array}$ & 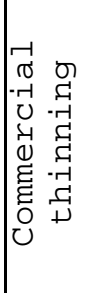 & 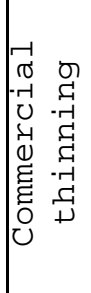 & $\mid \begin{array}{l}0 \\
0 \\
0 \\
4 \\
4 \\
0 \\
0 \\
0 \\
0 \\
0 \\
0\end{array}$ & 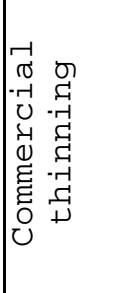 & \begin{tabular}{l}
0 \\
0 \\
0 \\
0 \\
3 \\
4 \\
0 \\
0 \\
+1 \\
-1 \\
0 \\
\multicolumn{1}{c}{} \\
$\omega$ \\
$\omega 2$
\end{tabular} & 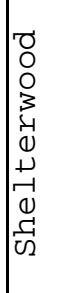 & $\begin{array}{l}0 \\
0 \\
0 \\
0 \\
3 \\
3 \\
0 \\
0 \\
+1 \\
-1 \\
0 \\
0 \\
-1 \\
02\end{array}$ & $\begin{array}{l}0 \\
0 \\
0 \\
1 \\
y \\
1 \\
0 \\
0 \\
0 \\
0 \\
02\end{array}$ & 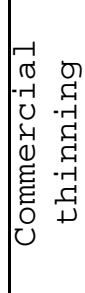 \\
\hline $\begin{array}{l}\text { 㥈 } \\
\text { 号 } \\
\text { ○ }\end{array}$ & $\begin{array}{l}m \\
-1 \\
6\end{array}$ & $\stackrel{r}{m}$ & $\begin{array}{l}\infty \\
0 \\
0 \\
\forall\end{array}$ & $\begin{array}{l}1 \\
0 \\
\infty \\
\infty\end{array}$ & $\mid \begin{array}{l}2 \\
0 \\
\infty\end{array}$ & $\begin{array}{l}\Omega \\
-1 \\
\infty\end{array}$ & $\begin{array}{l}\vec{H} \\
\stackrel{H}{H} \\
-H\end{array}$ & প & 20 & F & in & $\begin{array}{l}n \\
\frac{1}{6} \\
-i\end{array}$ & $\begin{array}{l}\widehat{\sigma} \\
\text { } \\
\sigma\end{array}$ & $\begin{array}{l}n \\
0 \\
\infty \\
-1 \\
-1\end{array}$ & $\begin{array}{l}0 \\
\infty \\
-1\end{array}$ & $\begin{array}{l}\sigma \\
\sigma \\
\vec{r}\end{array}$ \\
\hline 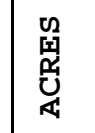 & 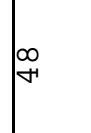 & $\underset{⿱ 亠 乂}{m}$ & $\stackrel{n}{\sim}$ & 艿 & 兄 & नু & in & 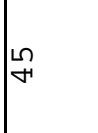 & m & $\infty$ & $\begin{array}{l}\curvearrowright \\
-\end{array}$ & $\mid \begin{array}{l}-1 \\
\infty\end{array}$ & $\mid \begin{array}{l}\infty \\
\curvearrowleft\end{array}$ & $\underset{r}{+}$ & $\begin{array}{l}\infty \\
-1\end{array}$ & $\underset{⿱ 中}{m}$ \\
\hline $\begin{array}{l}\text { 崮 } \\
\text { 号 }\end{array}$ & $\mid \begin{array}{l}m \\
w \\
1 \\
b \\
-1 \\
-1\end{array}$ & $\begin{array}{l}\overrightarrow{1} \\
\tilde{1} \\
1 \\
b \\
-1\end{array}$ & $\begin{array}{l}n \\
N \\
1 \\
b \\
-1 \\
\end{array}$ & 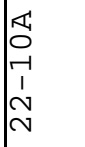 & 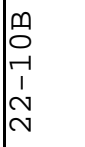 & $\begin{array}{l}U \\
0 \\
\cdots \\
1 \\
N \\
N\end{array}$ & $\begin{array}{l}-1 \\
-1 \\
1 \\
\sim \\
N\end{array}$ & $\begin{array}{l}\mathcal{N} \\
\overrightarrow{1} \\
\sim \\
\sim \\
N\end{array}$ & $\begin{array}{l}\vec{a} \\
\overrightarrow{1} \\
1 \\
\sim \\
\sim\end{array}$ & $\begin{array}{l}\tilde{N} \\
1 \\
1 \\
\sim \\
N\end{array}$ & $\begin{array}{l}\sigma \\
\sim \\
1 \\
\sim \\
\sim\end{array}$ & 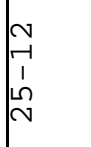 & $\begin{array}{l}m \\
\cdots \\
1 \\
\stackrel{\omega}{n} \\
\sim\end{array}$ & $\begin{array}{l}N \\
0 \\
1 \\
6 \\
N\end{array}$ & $\begin{array}{l}0 \\
-1 \\
1 \\
b \\
N\end{array}$ & $\begin{array}{l}n \\
0 \\
1 \\
\\
\end{array}$ \\
\hline 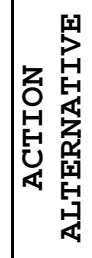 & ن & $\begin{array}{l}\text { à } \\
\dot{0} \\
\dot{0} \\
\dot{0}\end{array}$ & 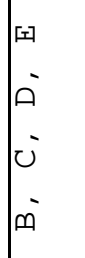 & $\begin{array}{l}\dot{y} \\
\dot{0} \\
\dot{0} \\
\dot{0}\end{array}$ & نं & $a^{\dot{0}}$ & نे & 되 & a & |r|r| & 되 & $\varpi$ & 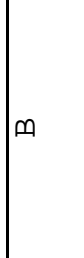 & $u$ & | & के \\
\hline
\end{tabular}




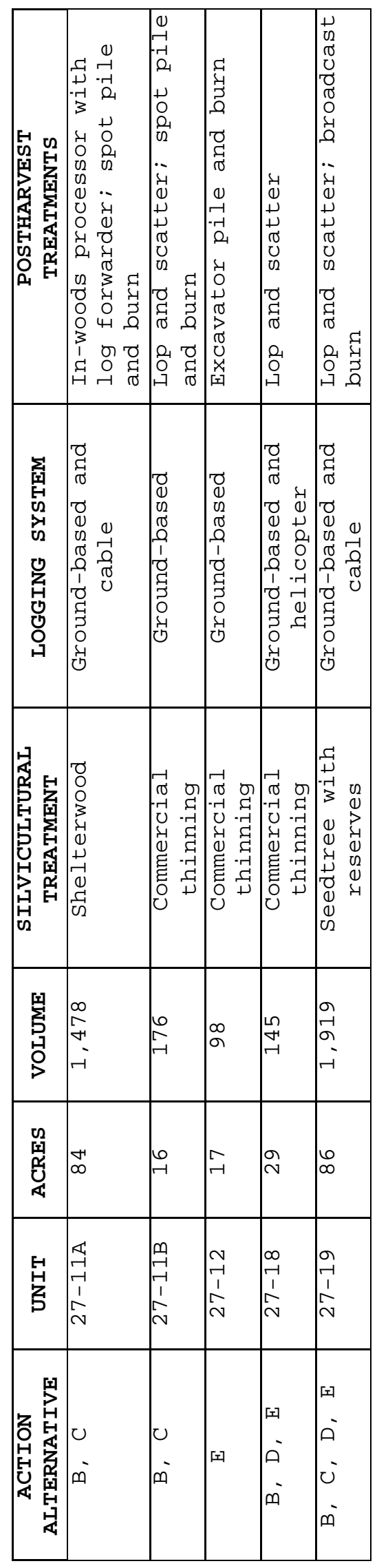

Page II-18

Three Creeks Timber Sale Project DEIS 


\section{MITIGATIONS}

The ID Team designed specific mitigation measures as part of the proposed project. Mitigation measures are designed to reduce impacts and protect resources during harvesting and road-improvement activities. APPENDIX A STIPULATIONS AND SPECIFICATIONS of the RESOURCE APPENDICES tracks mitigation measures pertinent to this project. Many mitigation measures would be incorporated into the Timber sale contract or sitepreparation contract clauses and be implemented through contract administration.

\section{MITIGATIONS COMMON TO ALL ACTION ALTERNATIVES BY RESOURCE}

This section describes the mitigations and design components common to all action alternatives.

\section{- Wildlife}

- Where a point within a seedtree unit exceeds 600 feet to hiding cover, clumps of reserve trees would be left to provide wildlife screening and hiding cover. Each reserve would be 1.7 to 3 acres in size.

- A minimum of 2 snags and 2 snagrecruitment trees 21 inches dbh and greater per acre, on average, would be retained in all harvest units. If trees 21inch or larger are not available, the next largest available size would be retained.

- In areas of riparian management, buffer widths were expanded to provide connectivity and corridors for wildlife movement.

\section{- Water Quality}

- Timber-harvesting activities would not occur within 25 feet of fish-bearing reaches of the 4 main streams (South Fork Lost, Cilly, Soup, and Unnamed creeks) and a riparian management zone will also be established on all fish-bearing reaches; this would meet or exceed the rules for the RMZ and SMZ laws.

- A segment of South Fork Lost Creek Road is near South Fork Lost Creek. Approximately 2 miles of road would be built farther north of the creek; the majority of the original segment would be reclaimed. This may reduce the potential risk of sediment delivery to the creek.

- While removing and installing the bridge on Soup Creek Road, construction work over the creek would be limited to July 15 through August 31. This is the period of the lowest streamflow, so that the risk of sediment entering the creek is minimized.

- During rehabilitation of the old bridge locations along south Fork Lost and Soup creeks, work over the creeks would be limited to July 15 through August 31 to reduce the risk of sediment entering the creek.

\section{- Soils}

- DNRC has identified areas of soil instability in the project area. A buffer of trees would be retained around a known slough, and new road construction would not occur in or adjacent to these areas.

- Skidding mitigation measures would include a restriction on the season of use, the utilization of minimum skidtrail spacing, the installation of needed erosion-control devices, the retention of woody debris, and following all applicable BMPs.

\section{- Fisheries}

- The frequency and volume of large woody debris would be monitored in South Fork Lost and soup creeks. 
- Stream temperatures would be monitored in South Fork Lost, Cilly, and Soup creeks.

- All applicable BMPs, SMZs, and Rules for soils and fisheries RMZs would be followed in fishbearing streams.

- Road-stream crossings would be monitored for sedimentation and deterioration of the road prism.

\section{ALTERNATIVES CONSIDERED BUT ELIMINATED FROM DETAILED ANALYSIS}

Two additional alternatives were considered, but were not analyzed in detail, following the preliminary analysis.

- The first alternative would have harvested only in stands not classified as old growth. Stands for this alternative were identified based on non-old-growth classification sawtimber presence and accessibility. Through preliminary analysis, determination was made that this alternative would not meet the volume objective and did not address the insect and disease objective for the project. The inability to enter old-growth stands where many of the insect and disease problems occur was the primary reason for not meeting the project objectives.

- The second alternative considered, but eliminated from detailed analysis, was proposed by 2 interested parties. This alternative suggested a sanitation/salvage-type approach with a diameter-limited thinning from below in grand fir. The proposed treatment would create small openings that are not conducive to the successful regeneration of seral species. Harvesting in older stands was not part of the alternative, which would not meet the project objectives of moving the landscape towards a desired future condition. Under this alternative, the objective of addressing insect and disease activities would not be met. The alternative prescriptions would favor the regeneration and retention of late successional species that are commonly affected by insects and diseases. The retention of mistletoe-infected trees would result in the further spread of infection and reduced growth in young trees.

Lastly, this alternative would not accomplish volume objectives established for the project. The proposal limits road building for accessing timber stands.

Harvesting is also limited to younger stands with smaller diameters and pockets of dead and dying trees. The estimated volume for the alternative was $3.4 \mathrm{mmb}$.

While this alternative, in its entirety, would not meet project objectives, Action Alternative $\mathrm{E}$ was developed to incorporate two of its main components. The amount of harvesting in old-growth areas was reduced and road building was minimized. Action Alternative $E$ is one of the 4 action alternatives and was analyzed in detail.

Additional information concerning these 2 alternatives is available in the project file at the Swan River State Forest office. 


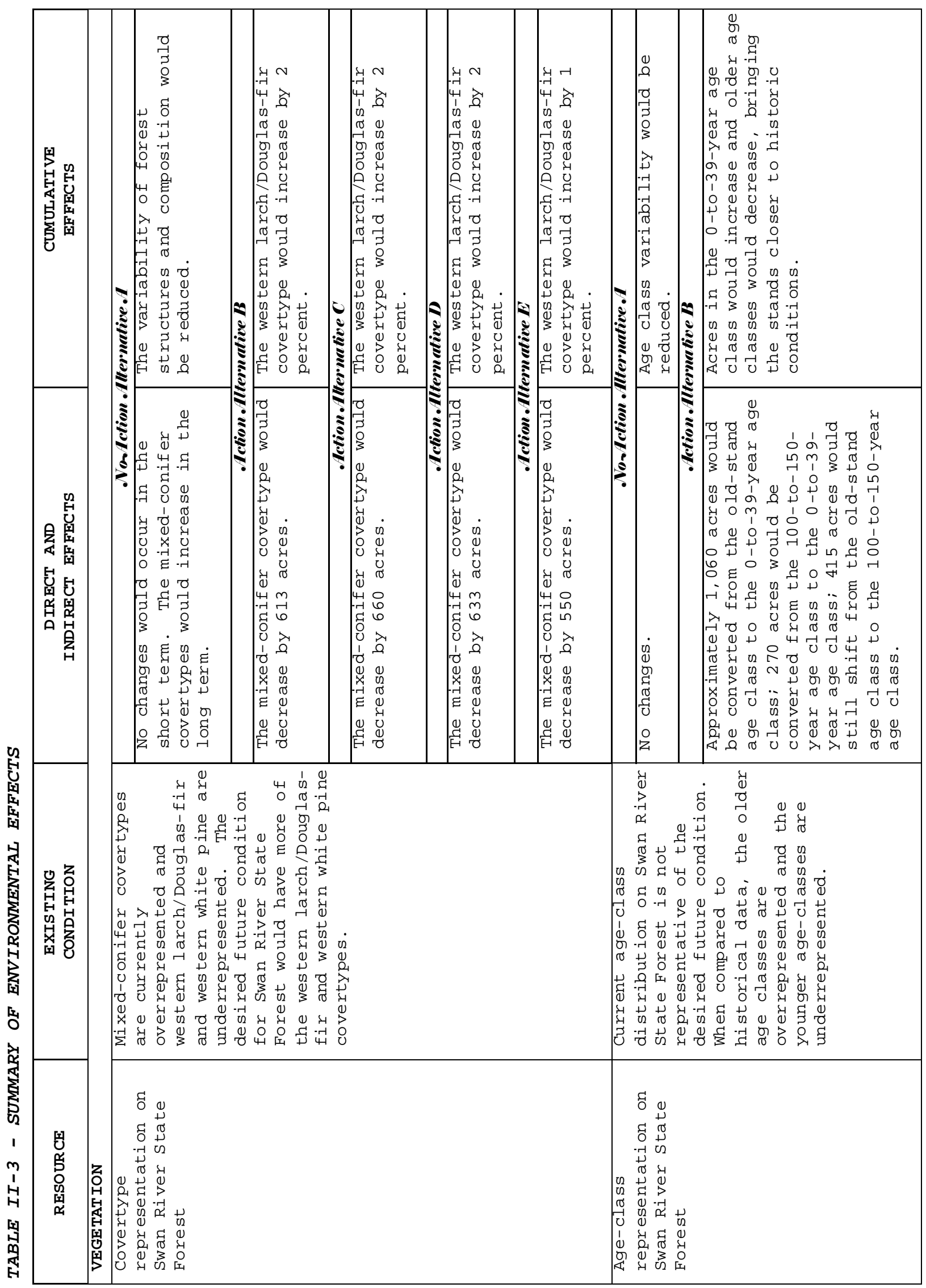




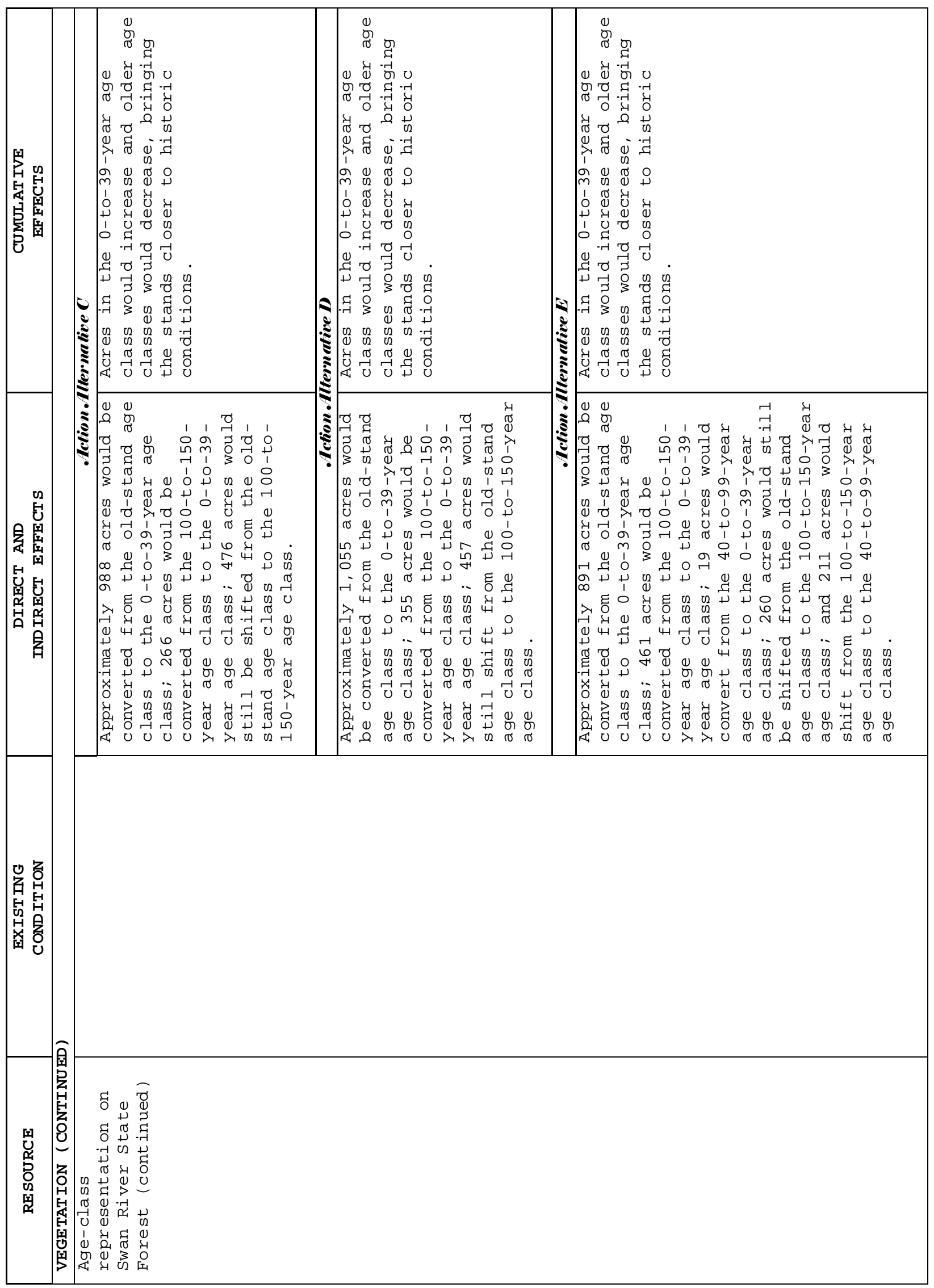

Page II-22

Three Creeks Timber Sale Project DEIS 


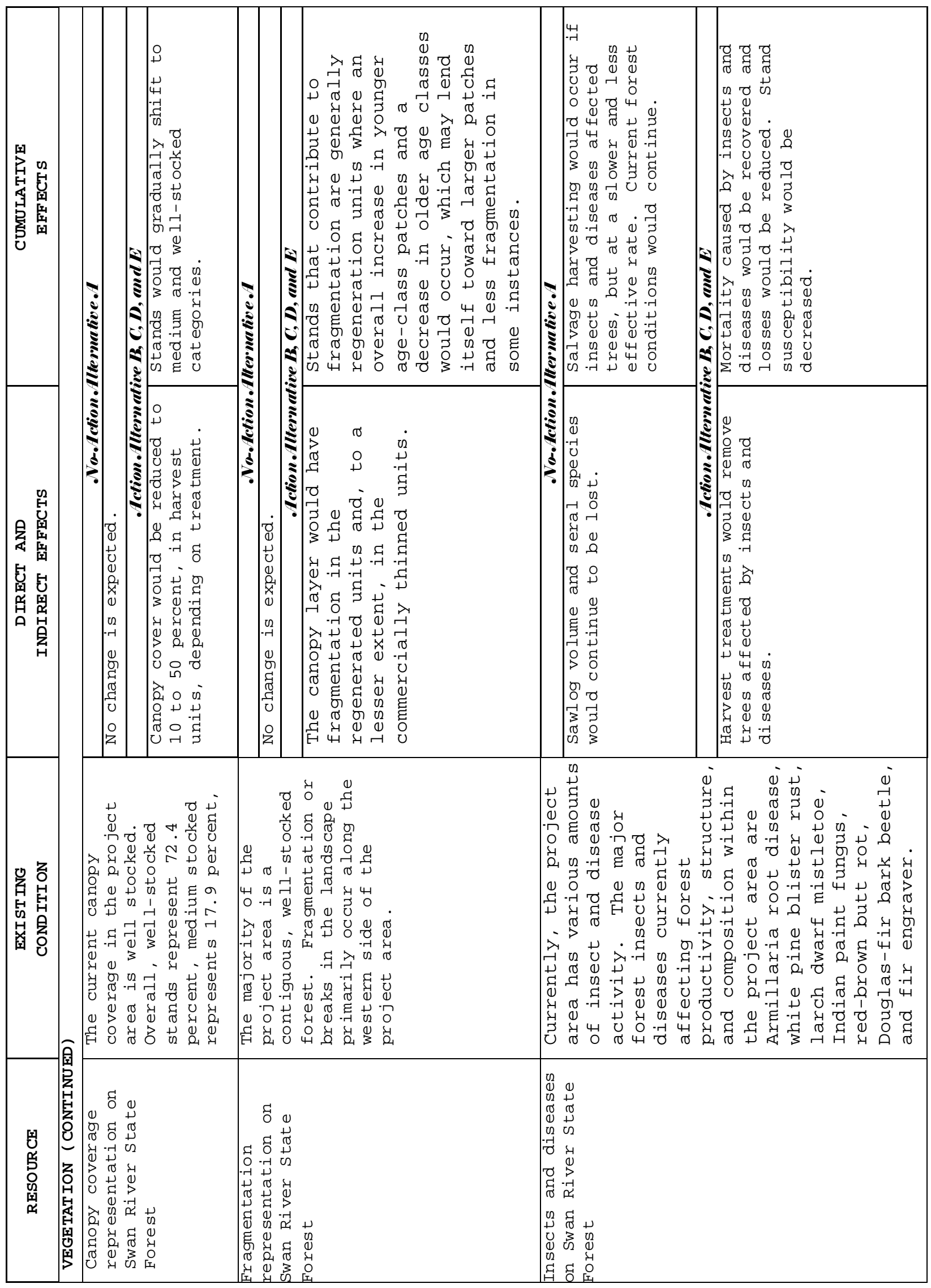




\begin{tabular}{|c|c|c|c|c|c|c|c|}
\hline 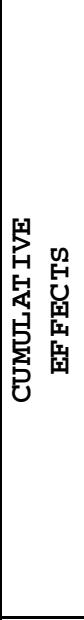 & & 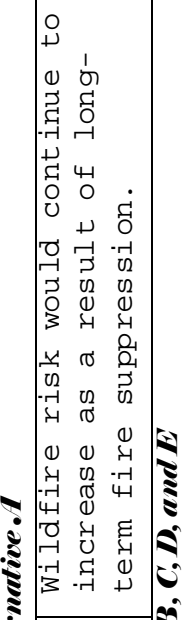 & 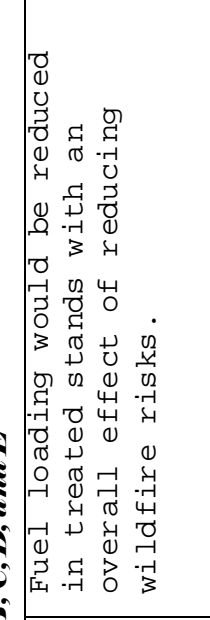 & 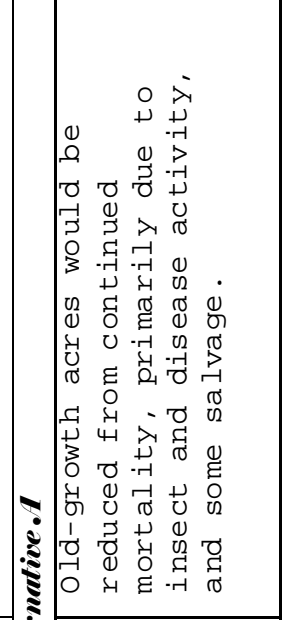 & 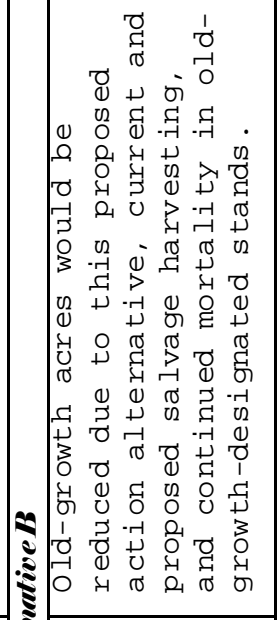 & 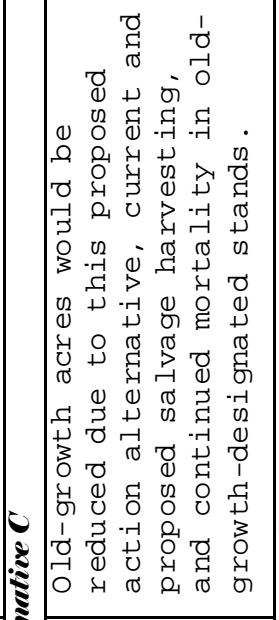 & 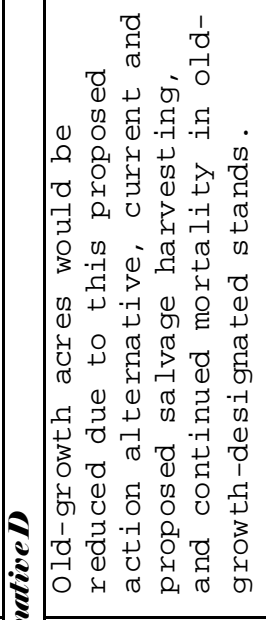 \\
\hline 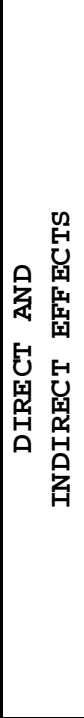 & & 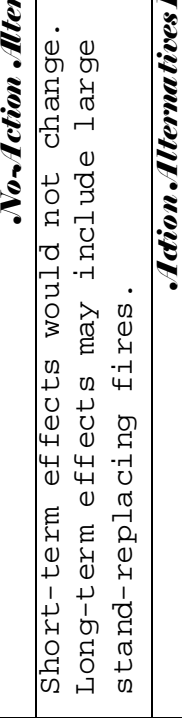 & 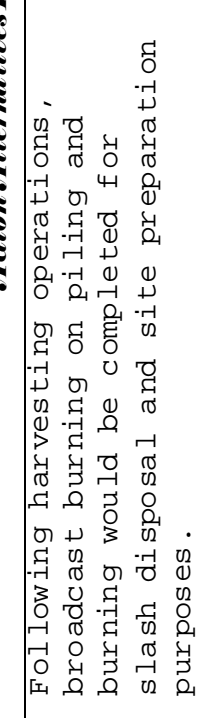 & 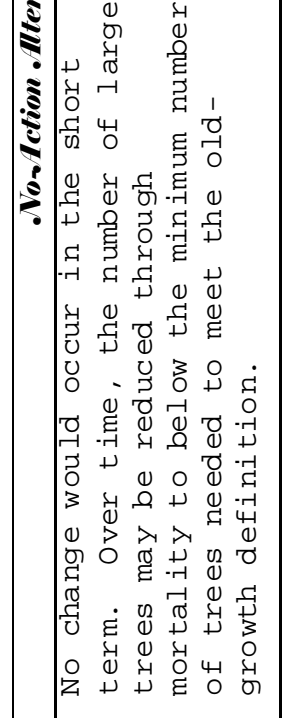 & 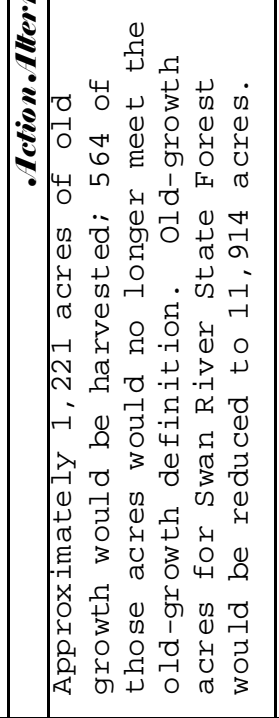 & 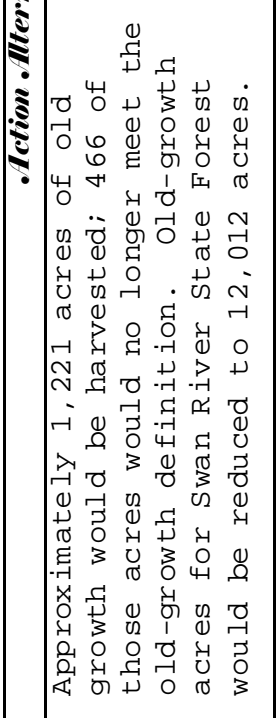 & 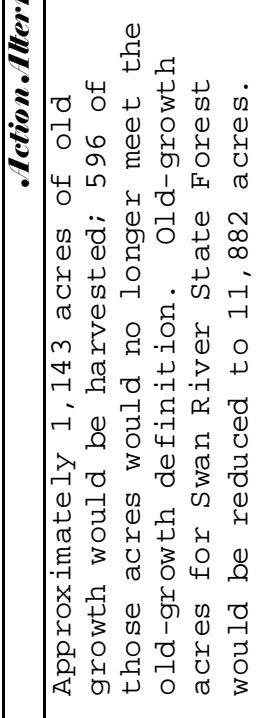 \\
\hline 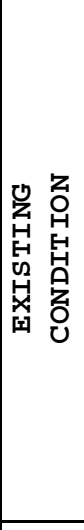 & \multicolumn{3}{|c|}{ 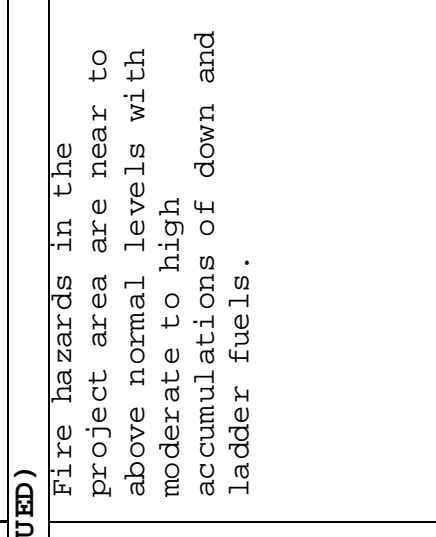 } & \multicolumn{4}{|c|}{ 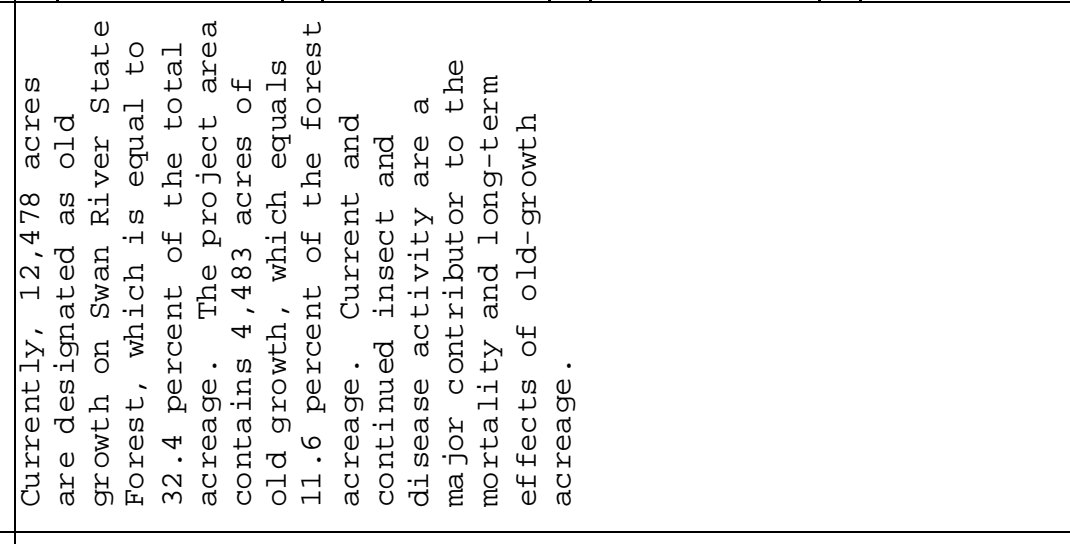 } \\
\hline 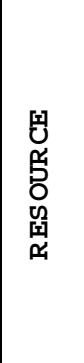 & & & & 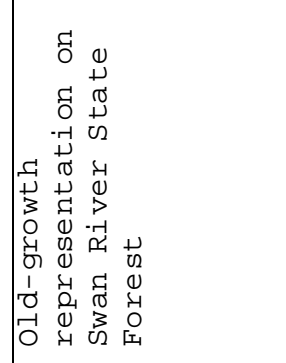 & & & \\
\hline
\end{tabular}

Page II-24

Three Creeks Timber Sale Project DEIS 


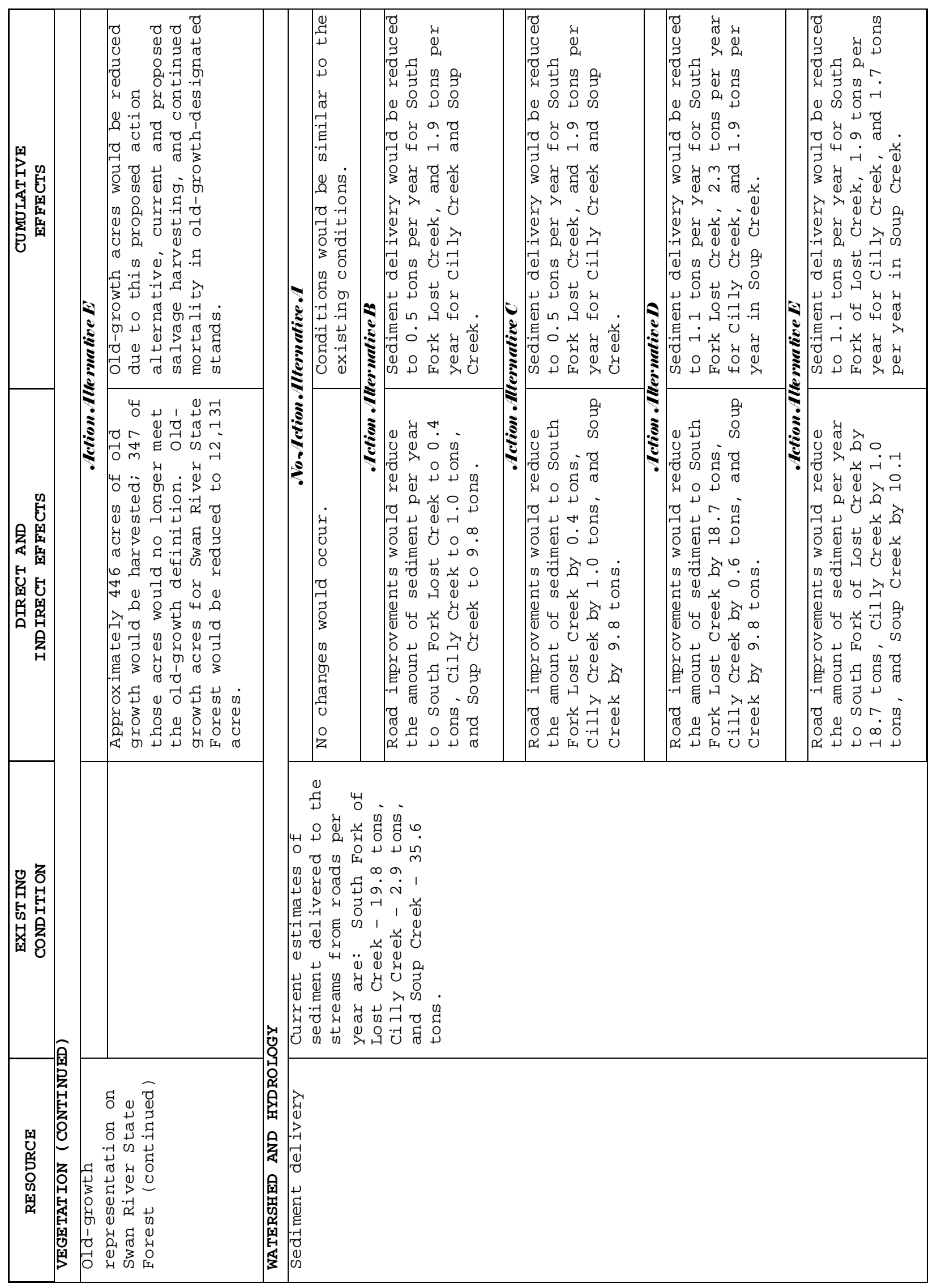




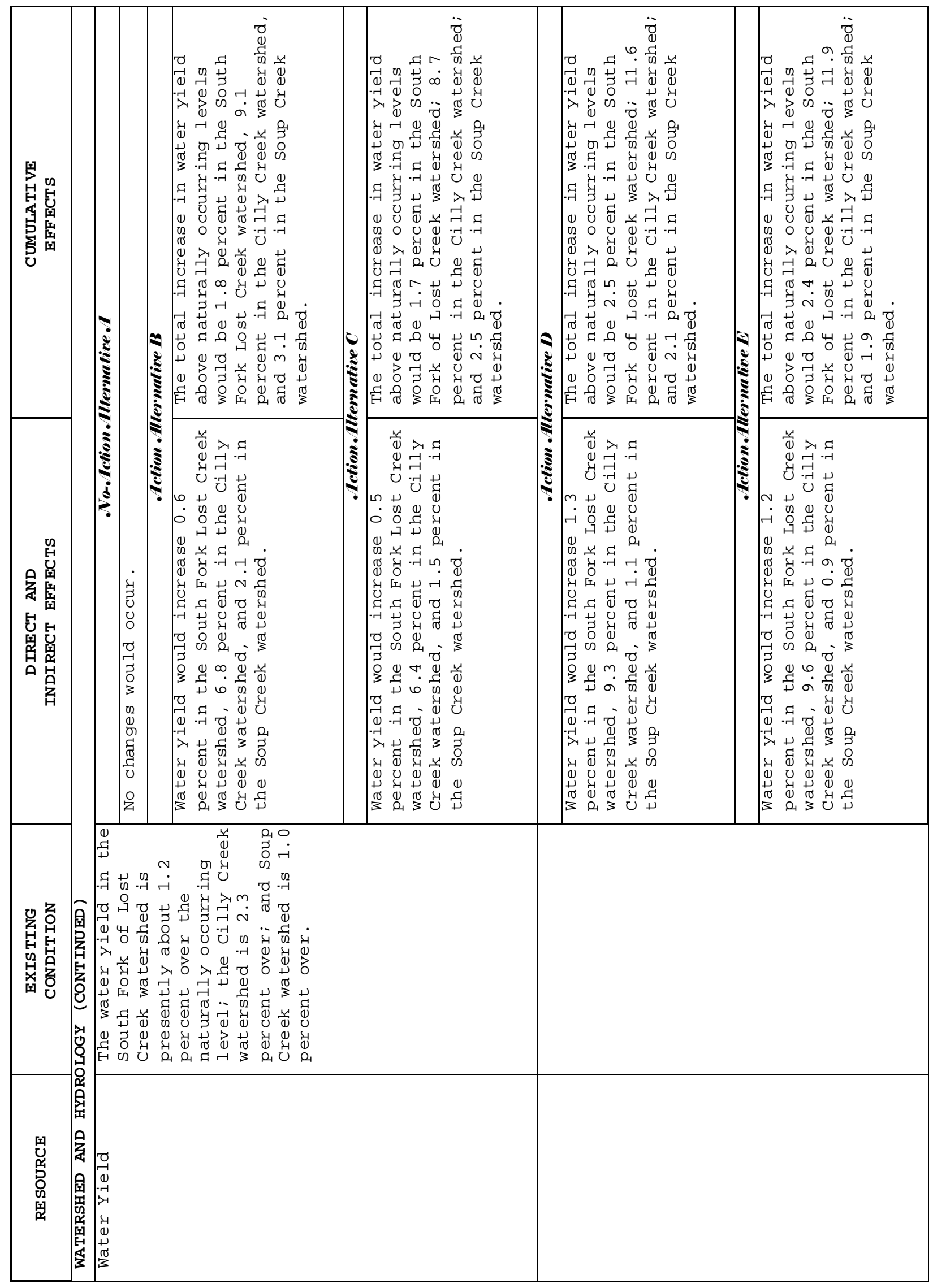

Page II-26

Three Creeks Timber Sale Project DEIS 


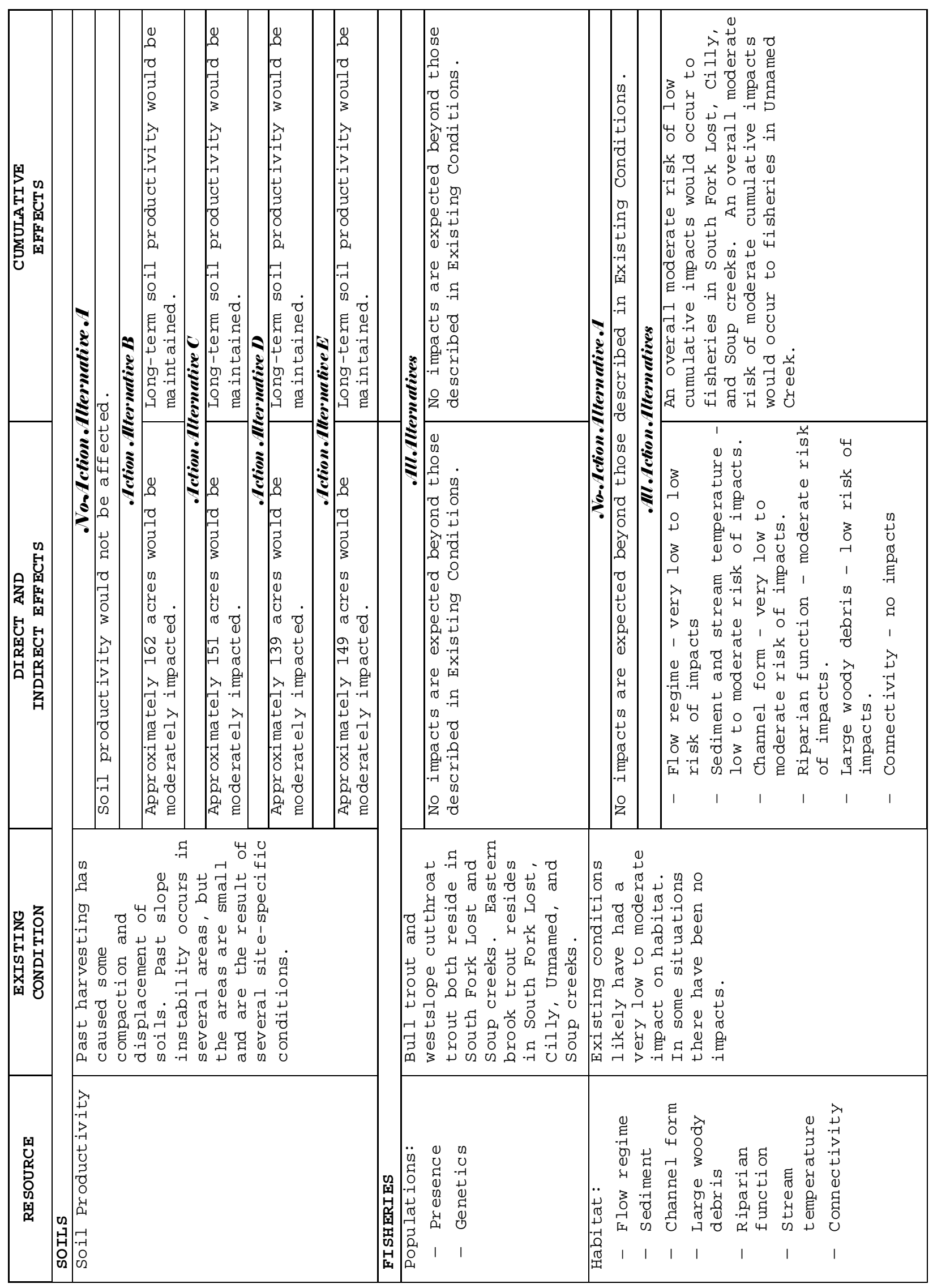




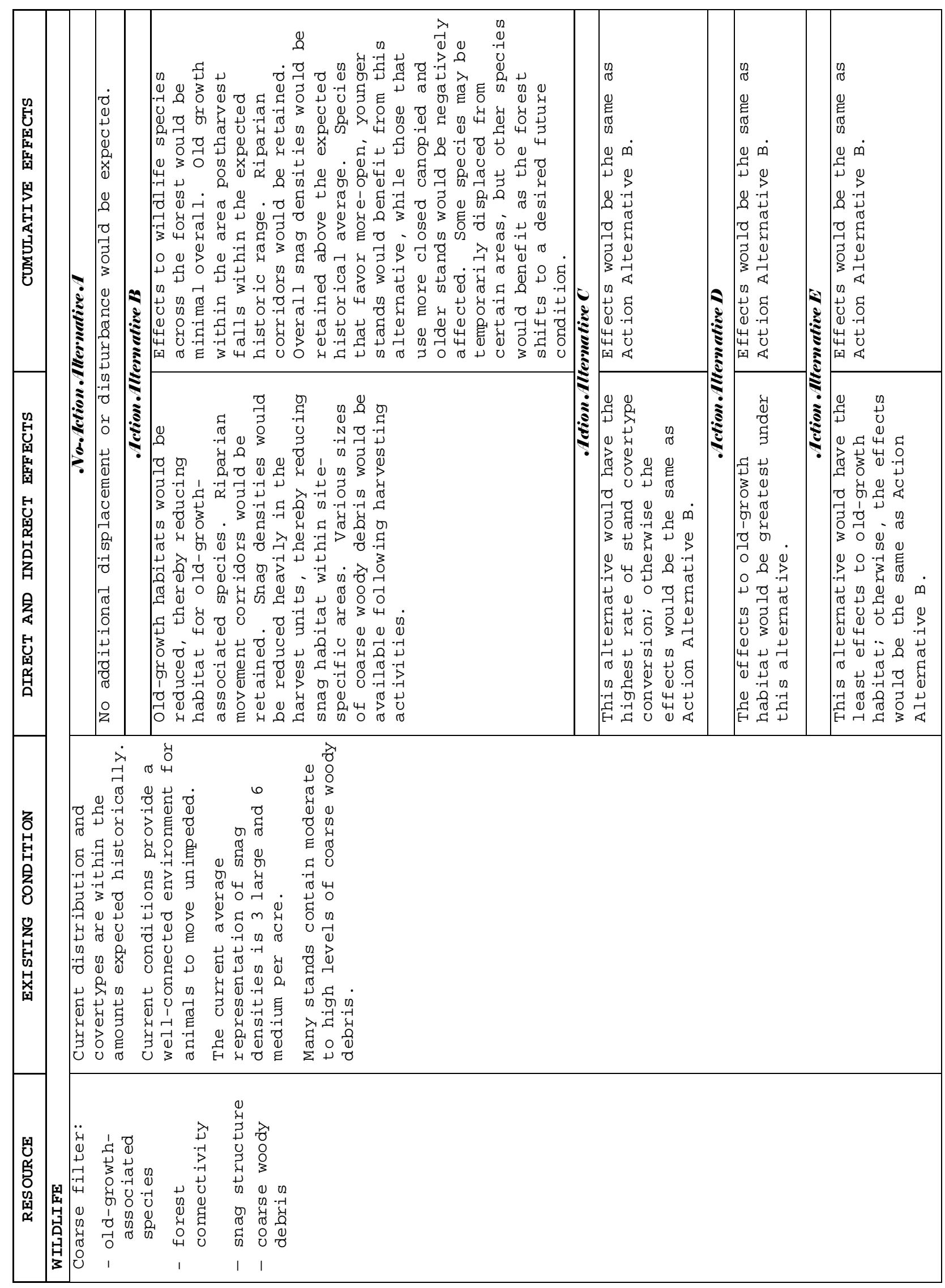

Page II-28 Three Creeks Timber Sale Project DEIS 


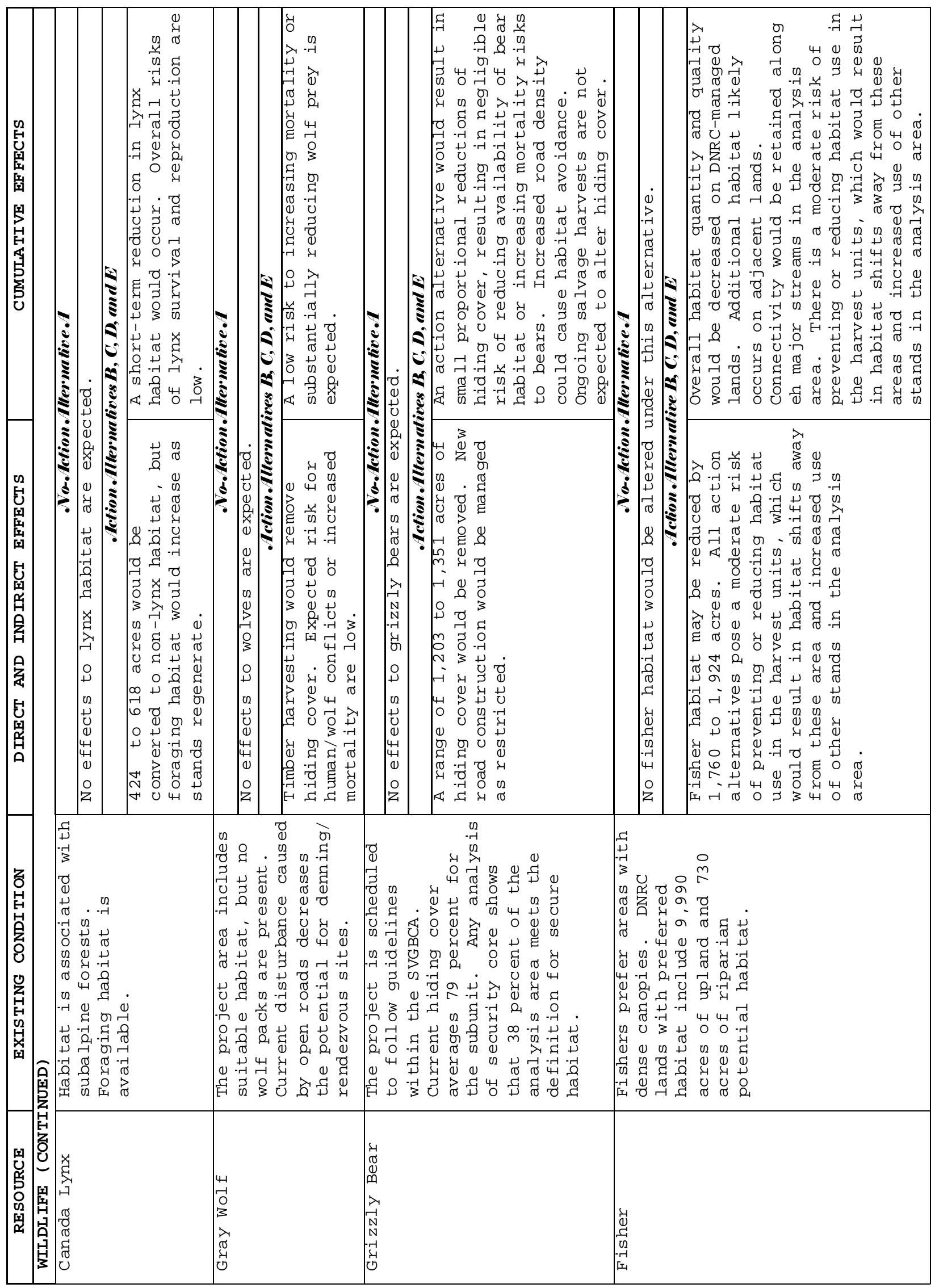




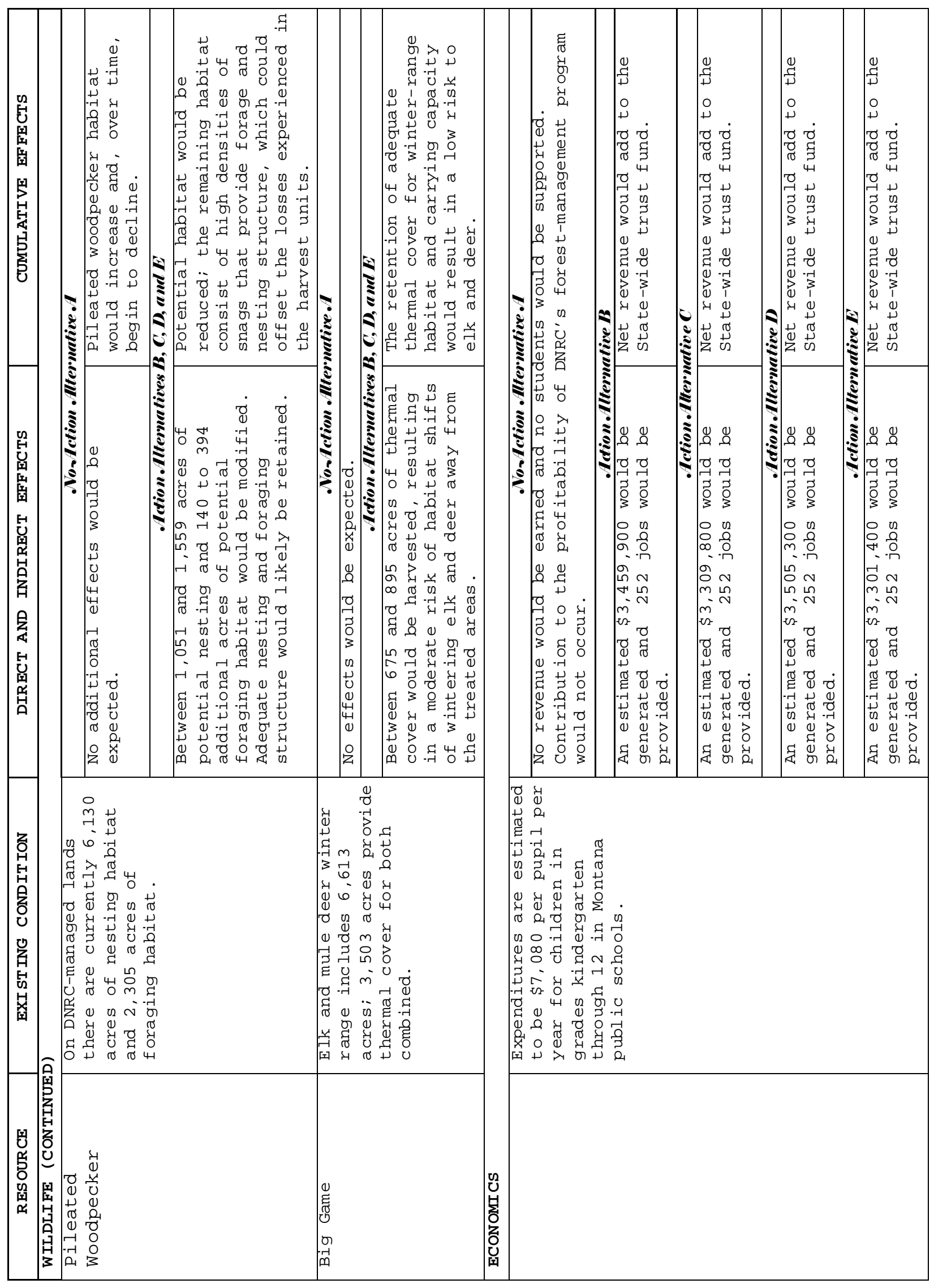

Page II-30 


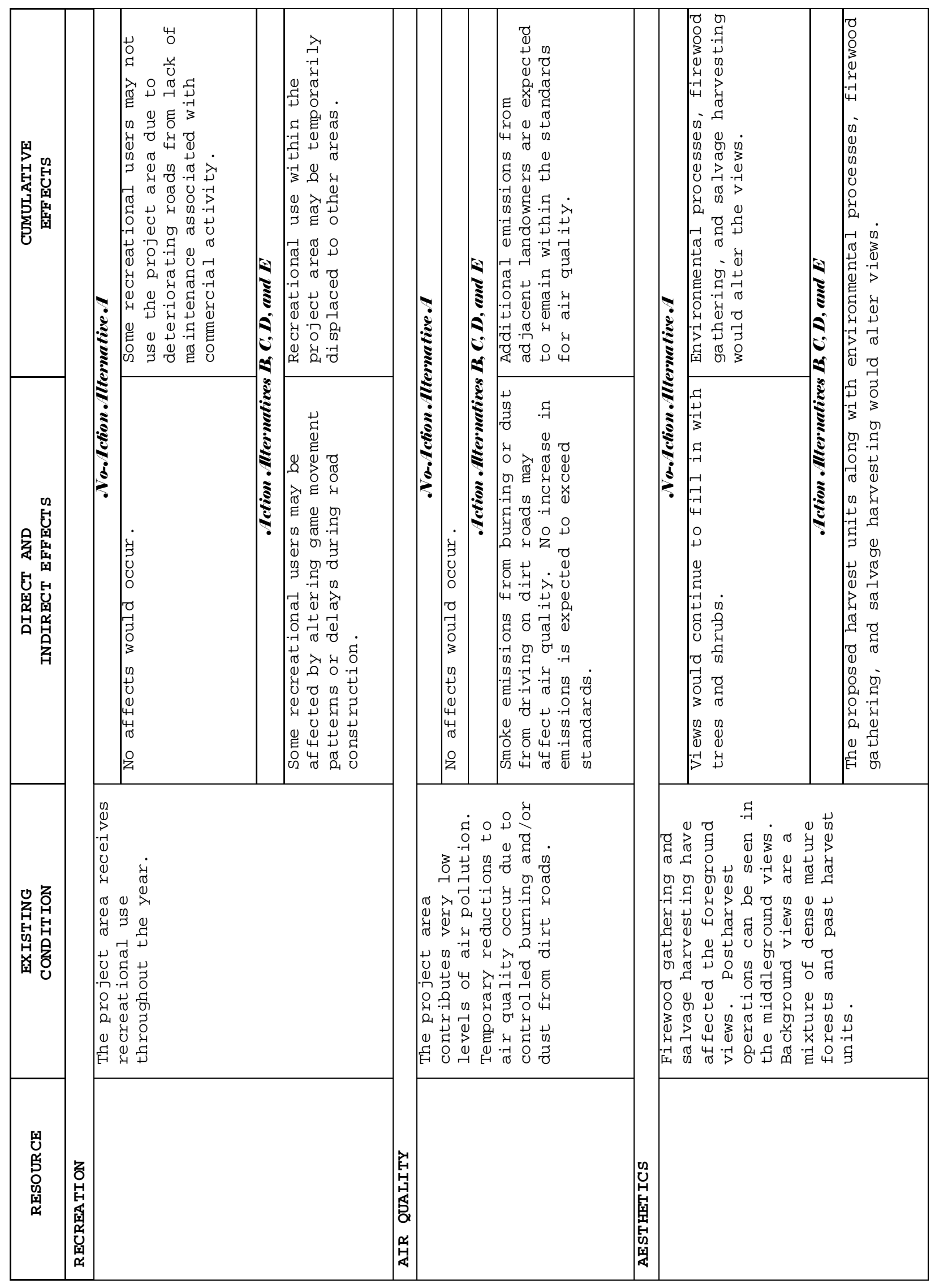




\section{THREE CREEKS TIMBER SALE PROJECT \\ CHAPTER III \\ EXISTING ENVIRONMENT AND \\ ENVIRONMENTAL CONSEQUENCES}

\section{INTRODUCTION}

This chapter is a summary of resource conditions as they relate to the proposed Three Creeks Timber Sale project. The current, or existing, condition can be viewed as a baseline to compare changes resulting from the selection of any alternative. How each alternative may affect the environment is also described. For more complete assessments and analyses related to the resources for both scientific and judicial review, refer to the appropriate appendices of this EIS.

\section{PROJECT AREA DESCRIPTION}

The Three Creeks Timber Sale Project area is located primarily in the northeast portion of Swan River state Forest.

- The project area encompasses approximately 10,626 acres in 16 sections and is primarily located in the South Fork Lost Creek, Cilly Creek, and Soup Creek drainages. All creeks in this area flow into Swan River, which empties into Swan Lake 7 miles to the north.

- The topography is composed of moderately steep valley slopes that vary from flat to 60 percent at elevations of 3,300 to 6,000 feet. Aspects are north, west, and south.

- The project area is accessed from Highway 83 via Lost Creek, Cilly Creek, and Soup Creek roads.

- The project area is a continuous block of state land with the exception of one section, which is USFS. All lands north and east of the project area are USES-managed lands. 


\section{VEGETATION ANALYSIS SUMMARY}

\section{INTRODUCTION}

This section describes current vegetative conditions on Swan River State Forest and addresses the potential effects of the alternatives as they relate to the following issues:

- movement toward or away from desired future conditions;

- management goals and activities that address insect and disease activities;

- current and future levels of forest fragmentation;

- impacts of harvesting on the amount and distribution of old growth, old-growth attributes, and the quality of old growth on Swan River State Forest;

- timber harvesting and associated activities may affect forest covertypes and age classes;

- timber harvesting and associated activities may reduce canopy cover;

- without timber harvesting, fire hazard may increase;

- timber harvesting and associated activities may decrease sensitive plant populations; and

- timber-harvesting and roadbuilding activities may increase noxious weeds in the project area.

\section{ANALYSIS METHODS}

This vegetation analysis compares historic forest conditions, desired future conditions, and current stand conditions in terms of forest composition. Historic age-class and covertype conditions were quantified by Losensky (1997). Forest inventory data from the $1930 \mathrm{~s}$ was used to estimate the proportion of historic age classes by forest covertype for Montana. This provided an estimate of age-class distribution and stand composition prior to Euro/American settlement and the effects of fire suppression, selective logging, cattle and sheep grazing, and the full impact of white pine blister rust. Current conditions and desired future conditions are defined using DNRC's site-specific Stand Level Inventory (SLI).

Forest fragmentation was analyzed by using aerial photographs of the project area and querying the SLI. Queries in the SLI provided information on contiguous areas of stands in the same age class, stocking levels, and stand densities. The effects of each alternative on the patch size of old-growth stands were also analyzed.

Insect and disease activities are recorded and mapped annually from aerial flight surveys. New occurrences and the progression of existing pockets, along with approximate acreages and locations, are collected. Field surveys identify areas with insect and disease activities for timberharvesting opportunities.

The old-growth analysis relies on both DNRC's SLI and plot-level data collected for the project. The SLI was queried to select stands meeting the age, dbh, and large-tree criteria for old growth based on habitat-type groups (see APPENDIX $M$ - GLOSSARY for DNRC's old-growth definition). Field surveys collected plot-level data in order to verify the old-growth status of selected stands and determine if additional stands meet the oldgrowth definition within the project area.

The analysis of stand development would be a qualitative discussion of the conditions of timber stands, including how various natural and man-caused disturbances and site factors have affected, and may continue to affect, timber-stand development. 


\section{ANALYSIS AREA}

The analysis area was examined at 3 nested scales:

- Section M333C: Historic conditions refer to those described by

Losensky (1997). In this analysis, the historic conditions for section M333C relate to Swan River state Forest in terms of age-class distributions by forest covertypes.

- Swan River State Forest: Current and desired future conditions were analyzed at the scale of the entire Swan River state Forest based on the Swan River State Forest SLI.

- Three Creeks Timber Sale Project Area: Within the project area, the effects to stands proposed for harvesting under each alternative would be analyzed.

\section{PAST MANAGEMENT}

The project area for the Three Creeks Timber Sale Project has not had a large timber sale since the 1980s. The first known harvesting, both inside and adjacent to the project area, took place in the early 1900s. Timber harvesting began in and adjacent to the project area during the $1960 \mathrm{~s}$. Other past harvesting included salvage, sanitation, and individual-selection treatments. The most previously harvested stands have regenerated successfully, either naturally or by planting, and are dominated by western larch, Douglas-fir, and, in some areas, ponderosa pine. Many units have recently been precommercially thinned.

\section{STAND DEVELOPMENT}

The natural processes of stand development and disturbance are influenced by environmental conditions and site characteristics, such as soil types, stand covertypes, forest health, elevation, and stand structure. The stand structures and species compositions can be greatly modified by natural disturbances such as wildfire and wind events. Without natural or human-caused disturbances, stands continue to move along the successional path, which leads to species conversion. In some instances, a previously open western larch/Douglas-fir stand begins developing an increasingly dense understory of grand fir and other shade-tolerant tree species. This process may eventually move the stand toward a mixed-conifer covertype. Many of the stands proposed for harvesting have this successional pattern occurring. These proposed treatments would reverse this process to earlier stages of succession dominated by seral species.

\section{HABITAT TYPES}

Site factors, such as soil type, aspect, elevation, growing season, and moisture availability, are combined to develop the classifications of habitat types, which are then used to describe successional development and timber productivity, among other things (Pfister et al. 1977). In the project area, 62 percent is categorized as belonging to the "warm and moist" habitat type. As these stands progress through successional stages, the mixedconifer covertype would become more dominant. The lower elevation, moist-subalpine habitat type (Fischer and Bradley, 1987) occurs on 25 percent of the project area. Five other habitat types are also represented in the project area.

\section{FOREST HEALTH}

One of the primary reasons for proposing this project is the level of insect and disease problems affecting the project area. Insects and diseases, which decrease vigor, reduce growth, cause mortality, remove stands from the old-growth classification, and result in lost economic value, are currently very active within the project area. specific insect and disease problems 


\section{VEGETATION ANALYSIS SUMMARY}

include elevated populations of mistletoe, the Douglas-fir beetle, and fir engraver; Indian paint fungus is common; and minor infestations of the mountain pine beetle, infections of white pine blister rust, and various heartrots occur throughout the project area. Ongoing salvage operations have been unable to keep pace with the increasing levels of insect and disease problems.

The insect and disease problems noted above have, in recent years, experienced elevated populations and rates of spread. Annual aerial observation flights are used to identify specific locations and track the rate of spread. To combat the loss of economic value due to insect and disease problems, Swan River State Forest averages 3 salvage permits per year; salvage permits average $200 \mathrm{mbf}$ on roughly 400 acres. Generally, only infected trees are removed within the treated acreage.

Some of the economic value of the timber is being captured through salvage harvests, but a greater amount of value is being lost due to the rate of mortality occurring. The sold salvage permits have averaged $\$ 244.86$ per mbf, whereas timber sales combining green timber and salvage have averaged \$250.56 per mbf. Insect and disease problems are spreading at approximately 400 acres per year and are affecting 3 mbf per acre. Current insect and disease activities exceed the salvage program operations.

\section{ELEVATION AND ASPECT}

The project area ranges in elevation from 3,400 to 6,600 feet. A large portion of the project area has a south-to-west-to-northwest aspect, resulting in sites that are relatively warmer and drier than those on north- or east-facing aspects. Warmer, drier stands typically develop overstories of western larch and/or Douglas-fir. Stands with north-facing slopes, entirely or in part, often have higher moisture availability and are often comprised of species such as western red cedar and true firs.

The majority (61 percent) of the old-growth stands proposed for harvesting are on south to west aspects between 3,500 and 4,500 feet in elevation. The sites with south to west aspect receive much direct sunlight and tend to have drier soils. Due to these sites being drier and warmer, shelterwood and commercial-thin treatments are proposed.

\section{STAND STRUCTURE}

Stand structure indicates a characteristic of stand development and how the stand would continue to develop. The disturbance regime or most recent disturbance event can also be reflected.

Single-storied stands are most often associated with stand-replacement events, such as severe fires or clearcut harvesting, and are more common in younger-aged stands where understory reinitiation has not begun. Two-storied stands are often associated with areas of less severe fires and usually have more fireresistant trees, such as western larch or Douglas-fir, left in the overstory. Two-storied stands frequently develop where an understory of shade-tolerant species grows under an even-aged overstory, such as subalpine fir growing under a canopy of lodgepole pine. 
The multistoried condition arises when a stand has progressed through time and succession to the point that shade-tolerant species are replacing a shade-intolerant overstory.

\section{COVERTYPE}

Covertypes describe the species composition of forest stands. Covertype representation often varies according to the frequency of disturbances.

FIGURE III-1 - PROPORTION OF HISTORIC CONDITIONS BY COVERTYPE FOR SWAN RIVER STATE FOREST, FIGURE III2 - CURRENT COVERTYPE PROPORTIONS FOR SWAN RIVER STATE FOREST, and FIGURE III-3 - DESIRED FUTURE CONDITION BY COVERTYPE ON SWAN RIVER STATE FOREST illustrate the proportion of forest occupied by various covertypes at differing scales and time periods.

Results indicate that mixed-conifer stands are currently overrepresented compared to historic data and desired future conditions. The western larch/Douglas-fir and western white pine covertypes are currently underrepresented in reference to the desired future condition.

\section{AGE-CLASS DISTRIBUTION}

Age-class distribution delineates another characteristic important for determining trends on a landscape level. Age-class distributions are tied to covertype representation and disturbance regimes, both of which vary over the landscape in relation to prevailing climatic conditions of temperature and moisture.

Historical stand age-class distributions for Montana were developed by Losensky (1997). This data represents the best baseline available for determining how current forest age-class distribution deviates from historical conditions.
Comparison of the current age-class distribution by covertype across the entire Swan River state Forest to historical data from section M333C demonstrates reduced acreage in the seedling-sapling age class and an overabundance in the 150+-year-old age class in most covertypes. The historic data indicates Swan River State Forest avoided major disturbances for a considerable time period.

\section{ALTERNATIVE EFFECTS TO COVERTYPES AND AGE CLASSES}

Direct and Indirect Effects

\section{- Direct and Indivect Effects of . VoaAction Alternative A to Covertypes and . Age Classes}

In the short term, the amount of covertypes would remain lower than DNRC's desired future condition suggests. The long-term effects on covertype would continue, with a gradual loss of the seraldominated covertypes, such as western larch/Douglas-fir and western white pine, and an increase in the mixed-conifer covertype, which is dominated by shade-tolerant species.

No immediate change in the proportion of existing age classes is expected unless a large disturbance, such as a wildfire, occurs.

Forest succession, driven by the impacts of forest insects and diseases when fires are being suppressed, would reduce the variability of covertypes and age classes. As a forest ages and its composition become more

homogeneous, biodiversity would be reduced.

\section{- Direct and Indivect Effects of.Action} -Alternative B to Covertypes and . Age Classes

Approximately 613 acres of the mixed-conifer covertype would be converted to a western larch/Douglas-fir covertype by harvesting shade-tolerant species. An additional 494 acres of the 
FIGURE III-1 - PROPORTION OF HISTORIC CONDITIONS BY COVERTYPE FOR SWAN RIVER STATE FOREST

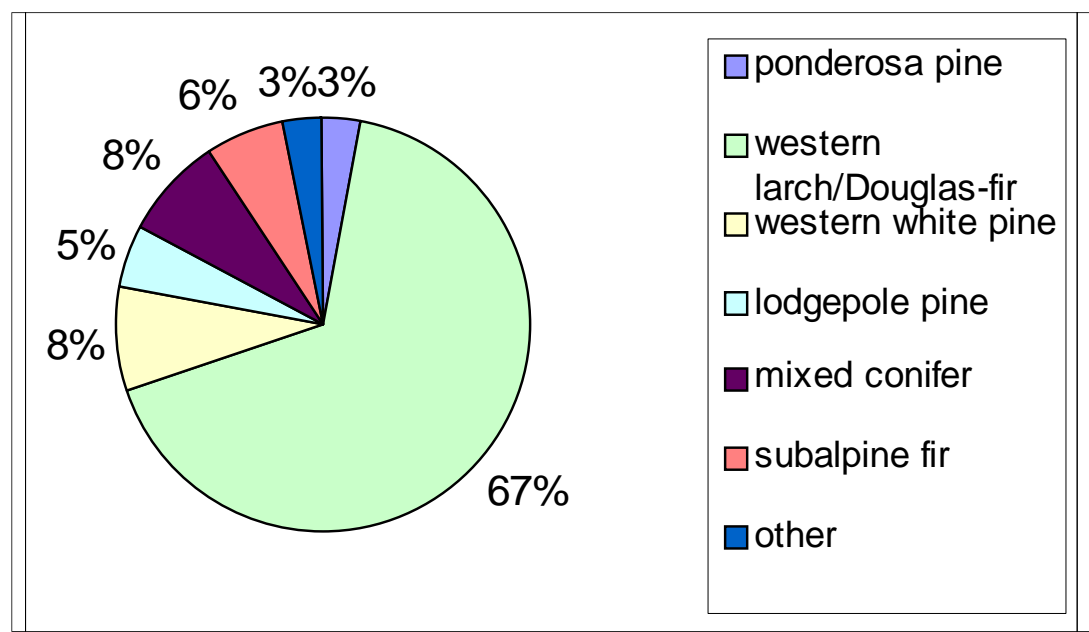

FIGURE III-2 - CURRENT COVERTYPE PROPORTIONS FOR SWAN RIVER STATE FOREST

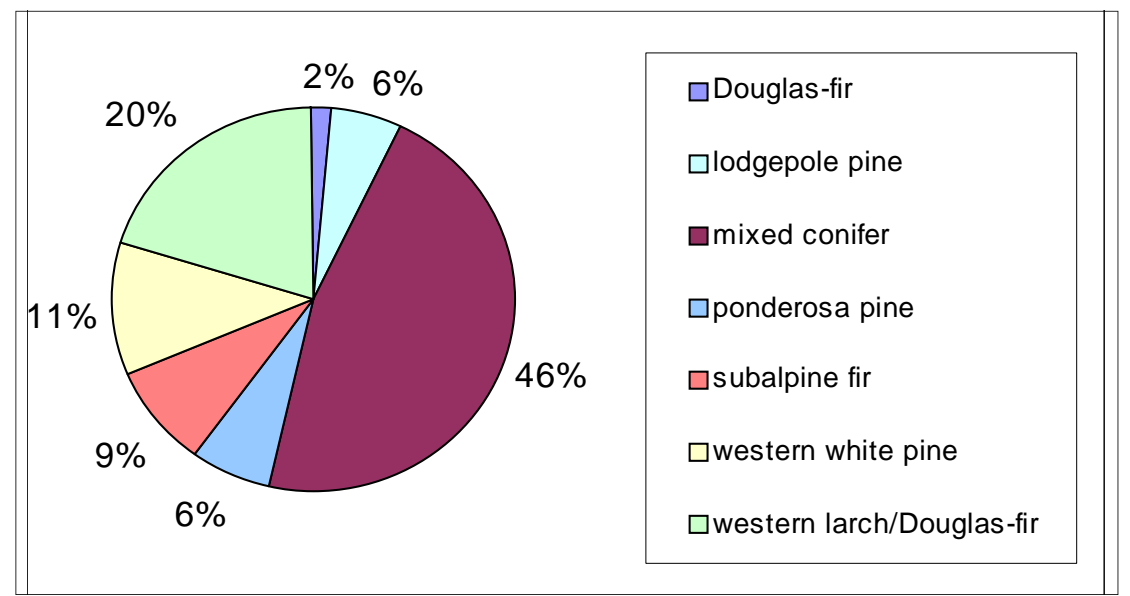

FIGURE III-3 - DESIRED FUTURE CONDITION BY COVERTYPE ON SWAN RIVER STATE FOREST

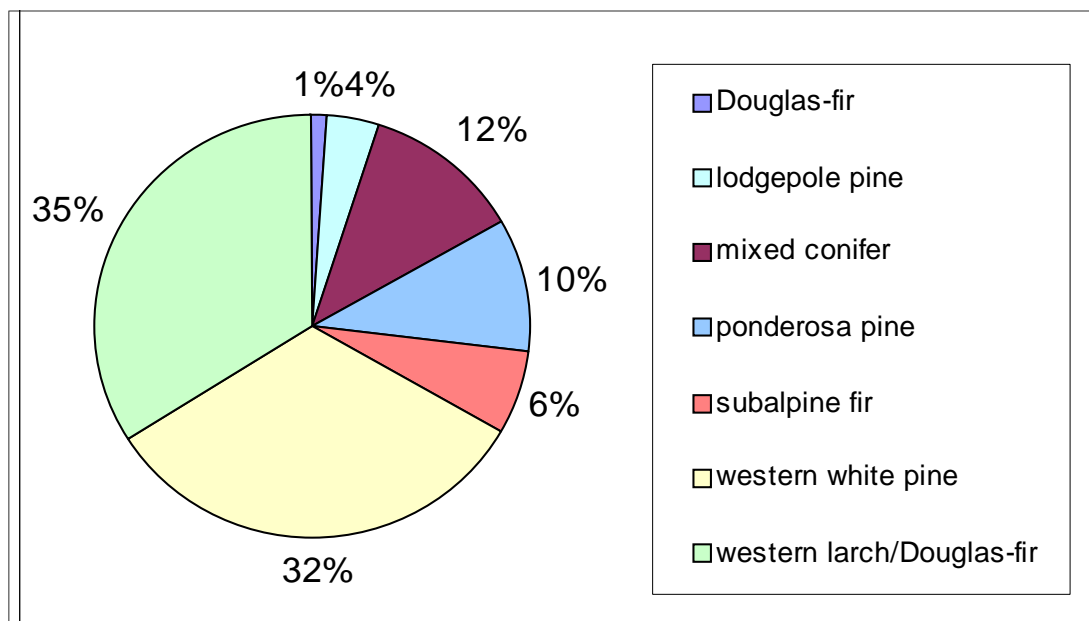


mixed-conifer covertype and 650 acres of the western larch covertype would be harvested, but no change in covertype would be expected. The proportion of the western larch/Douglas-fir covertype would increase due to a combination of harvesting prescriptions and planting. Approximately 127 acres within the western white pine covertype would be harvested; no change in covertype would be expected.

The proposed shelterwood, seedtree, and seedtree-withreserves treatments would regenerate approximately 1,331 acres; of this, 1,060 acres would be converted from the old-stand age class to the zero-year age class; the remaining 271 acres would be converted from the 100to-150-year age class to the zeroyear age class.

The 553 acres proposed for commercial thinning would retain pole- to sawtimber-sized trees in the 100-to-150-year age class, thus converting 415 acres from the old-stand age class to the 100-to150-year age class. In addition, 6 acres would convert from the 100-to-150-year age class to the 40-to-99-year age class and 95 acres would remain in the 100-to149-year age class following harvesting.

The regeneration treatments and subsequent planting or natural regeneration would increase the proportion of the 0-to-39-year age class on Swan River State Forest by 3.5 percent, or 1,331 acres, while the proportion of the oldstand age class would be reduced by 3.8 percent, or 1,475 acres.

\section{- Direct and Indirect Effects of. Iction} Alternative C to Covertypes and . Age Classes

Approximately 660 acres of the mixed-conifer covertype would be converted to the western larch/Douglas-fir covertype by harvesting shade-tolerant species. An additional 394 acres of the mixed-conifer covertype and 580 acres of the western larch covertype would be harvested, but no change in covertype is expected. The proportion of the western larch/Douglas-fir covertype would increase due to a combination of harvesting prescriptions and planting. Approximately 127 acres of western white pine and 24 acres of ponderosa pine covertypes would be harvested, but current representation should be maintained.

The proposed shelterwood, seedtree, and seedtree-withreserves treatments would regenerate approximately 1,253 acres; 988 acres would be converted from the old-stand age class to the zero-year age class, while 266 acres would be converted from the 100-to-150-year age class to the zero-year age class.

The 532 acres proposed for commercial thinning would retain pole- to sawtimber-sized trees in the 100-to-150-year and 40-to-99year age classes. A total of 476 acres would be converted from the old-stand age class to the 100-to150-year age class. In addition, 6 acres would convert from the 100-to-149-year age class to the 40-to-99-year age class and 50 acres would be retained in the 100-to-149-year age class.

The regeneration treatments and subsequent planting or natural regeneration would increase the proportion of the 0-to-39-year age class on Swan River State Forest by 3.5 percent, or 1,253 acres, while the proportion of the oldstand age class would be reduced by 3.8 percent, or 1,464 acres. 


\section{- Direct and Indivect Effects of.Action -Atternative D to Covertypes and Age Classes}

Approximately 633 acres of the mixed-conifer covertype would be converted to the western larch/Douglas-fir covertype by harvesting shade-tolerant species. An additional 529 acres of the mixed-conifer covertype and 595 acres of the western larch covertype would be harvested, but no change in covertype is expected. The proportion of western larch/Douglas-fir covertype would increase due to a combination of harvesting prescriptions and planting.

The proposed shelterwood, seedtree, and seedtree-withreserves treatments would regenerate approximately 1,410 acres; of this, 1,055 acres would be converted from the old-stand age class to the zero-year age class, and the remaining 355 acres would be converted from the 100to-150-year age class to the zeroyear age class.

The 560 acres proposed for commercial thinning would retain pole- to sawtimber-sized trees in the 100-to-150-year and 40-to-99year age classes. A total of 457 acres would be converted from the old-stand age class to the 100-to150-year age class. In addition, 8 acres would convert from the 100-to-149-year age class to the 40-to-99-year age class and 95 acres would be retained in the 100-to-149-year age class.

The regeneration treatments and subsequent planting or natural regeneration would increase the proportion of the 0-to-39-year age class on Swan River state Forest by 3.7 percent, or 1,410 acres, while the proportion of the oldstand age class would be reduced by 3.9 percent, or 1,512 acres.
- Divect and Indivect Effects of.Action Alternative E to Covertypes amd Age Classes

Approximately 550 acres of the mixed-conifer covertype would be converted to the western larch/Douglas-fir covertype by harvesting shade-tolerant species. An additional 451 acres of the mixed-conifer covertype and 735 acres of the western larch covertype would be harvested, but no change in covertype is expected. The proportion of western larch/Douglas-fir covertype would increase due to a combination of harvesting prescriptions and planting.

The proposed shelterwood, seedtree, and seedtree-withreserves treatments would regenerate approximately 1,371 acres; of this, 891 acres would be converted from the old-stand age class to the zero-year age class, and the remaining 461 acres would be converted from the 100-to-150year age class to the zero-year age class. Additionally, 19 acres would convert from the 40-to-99year age class to the zero-year age class.

The 628 acres proposed for commercial thinning would retain pole- to sawtimber-sized trees in the 100-to-150-year and 40-to-99year age classes. A total of 260 acres would be converted from the old-stand age class to the 100-to150-year age class. In addition, 211 acres would convert from the 100-to-149-year age class to the 40-to-99-year age class and 157 acres would be retained in the 100-to-149-year age class.

The regeneration treatments and subsequent planting or natural regeneration would increase the proportion of the 0-to-39-year age class on Swan River state Forest by 3.5 percent, or 1,352 acres, while the proportion of the oldstand age class would be reduced by 2.99 percent, or 1,151 acres. 


\section{Cumulative Effects}

\section{- Cumulative Effects of.All.Alternatives to Covertypes and .Age Classes}

The cumulative effects of recent forest management on Swan River State Forest resulted in a trend of increasing seral covertypes across areas where management occurred. The western larch/Douglas-fir covertype has increased by 3 percent through timber harvesting and planting in selected units.

In addition to the changes in proportions of covertype, the trend is toward increasing acres in the 0-to-39-year age class.

\section{CANOPY COVER}

Canopy cover, an estimate of the ratio between tree crown area and ground surface area, is usually expressed in terms of percent and is another measure of stand stocking/density.

In terms of overall canopy cover within the project area, 72.4 percent of stands are well-stocked, 17.9 percent show medium stocking, and less than 10 percent are poorly stocked or nonstocked. Sawtimber stocking within the project area shows that 45.5 percent of stands are well stocked, while 18.7 percent of stands have medium sawtimber stocking. The poorly stocked category consists of a minor proportion of the project area and these stands are typically in higher elevation, which have high quantities of rock and/or brush. Timber in these stands is generally not of good merchantable quality.

\section{ALTERNATIVE EFFECTS TO CANOPY COVER}

\section{Direct and Indirect Effects}

\section{- Direct and Indirect Effects of .Vo-Action -Alternative.A to Camopy Cover-}

Canopy cover would not change in the short term. Over time, individuals and groups of trees would be removed from the canopy by insects, diseases, windthrow, or fires, and variable changes to canopy cover would result as canopy gaps are created and gradually filled. Patches of variable size currently exist where the Douglas-fir beetle has killed large Douglas-fir.

- Direct Effects of Action .Alternatives B, C, D, and E to Camopy Cover

The reduction in canopy cover subsequent to harvest treatments would vary by action alternative and its silvicultural

prescription. In general, reduced canopy cover affects stand growth and development by reducing competition among the crowns of overstory trees, by reducing competition for water and nutrients, by establishing a more universe and vigorous understory, and allowing sunlight to reach the forest floor.

In areas with seedtree or seedtree-with-reserve harvesting, the canopy coverage would decrease to 10 to 25 percent, with the exception of the reserve areas where the canopy would remain intact. In the shelterwood harvesting, the canopy would decrease to 15 to 45 percent. Commercial thinning would decrease the canopy coverage to 40 and 50 percent.

Riparian stands associated with perennial streams and adjacent to a harvest unit would be treated and experience reduced canopy coverage. The designated primary streams that would be treated are South Fork Lost, Soup, and Cilly creeks and an unnamed tributary in Section 22, T24N, R17W. In areas where harvesting is proposed, a no-harvest zone would consist of the area from bankfull or highwater edge to 25 feet. From 25 to 150 feet, selective harvesting would occur. A maximum of 50 percent of the trees 8 inches $\mathrm{dbh}$ and greater may be harvested while 
maintaining a minimum of 40percent overstory crown closure.

Additionally, some harvesting would occur within the RMZ, but outside the SMZ. Small openings up to 0.25 acre in size would be allowed as long as a 40-percentaverage canopy closure could be achieved throughout the affected area.

\section{- Indirect Effects of.Action .Alternatives B, C, D, and E to Camopy Cover}

Canopy cover would increase over time as regeneration replaces the harvested trees in stands that received seedtree and shelterwood treatments. Fifteen to twenty years would be needed to develop a canopy cover of 70 to 100 percent.

The canopy cover in commercially thinned stands would return to preharvest conditions in approximately 20 to 30 years, depending on the level of removal.

\section{FRAGMENTATION}

Forest fragmentation refers to the breaking up of previously contiguous blocks of forest. Most often, fragmentation is used in reference to the disruption of large contiguous blocks of mature forest caused by forest-management activities such as road building and timber harvesting. In relation to fragmentation, management activities begin by putting holes in the natural forested landscape. As management continues and more harvesting takes place, the open patches created can become connected to other open patches, thus severing the previously existing connections between patches of mature forest. While the appropriate level of fragmentation for any particular forest is unknown, forests fragmented by management activities generally do not resemble natural forest conditions.

The majority of the project area exists as a contiguous forest of well-stocked stands with closed canopies. Stands in the western part of the project area have been fragmented to some degree. Some man-made patches in harvest units range from 20 to 100 acres.

\section{ALTERNATIVE EFFECTS TO FRAGMENTATION}

\section{Direct and Indirect Effects}

\section{- Direct and Indirect Effects of. Vo-oction -Alternative. A to Fragmentation}

Forest fragmentation would not be directly affected. Over time, and depending on an unknown future, indirect effects would include a reduction in fragmentation as additional harvesting is not imposed by management and existing patches of nonmature forest grow to maturity.

\section{- Direct Effects of Action .Altermatives B, C, D, and E' to Fragmentation}

For the areas proposed for regeneration harvesting, the primary effects would be the creation of a larger area of younger stands with a corresponding reduction in mature forest stands. In the stands designated for seedtree reserves, one or more patches (ranging in size from 1.7 to 4 acres) would be untreated, but the treatment would contribute to the fragmentation of mature forests and reduce the distance between open- and closed-canopy stands.

The units designated for commercial thinning would show less

fragmentation of the canopy layer. Commercial-thin units would be more similar to the adjacent mature stands of timber than would the regeneration harvest units and, therefore, would not contribute to fragmentation.

\section{- Indirect Effects of.Action .Altermatives B, C, D, and E to Fragmentation}

Some regeneration harvest units are adjacent to past harvest areas and other proposed units, which would result in an enlargement of patches of a younger age class. The end result would be more of a blended 
geometric shape of larger regeneration units. The large size of regeneration units would result in larger mature stands in the future, thus reducing fragmentation. However, future timber harvesting would result in additional fragmentation if existing mature timber patches received a regeneration harvest. The actual net effect on fragmentation would depend on future timber harvesting.

In units where commercial-thin treatments would be accomplished, the harvesting would result in smaller differences between adjacent stands and would not contribute to fragmentation.

\section{Cumulative Effects to Fragmentation}

- Cumulative Effects of.Action .Alternatives B, C, D, and E to Fragmentation

An overall increase in the size of younger age-class patches and a decrease in the size of older age classes would occur where regeneration harvest units are proposed.

\section{INSECTS AND DISEASES}

Aerial observation is utilized to map insect and disease problems on Swan River state Forest. DNRC and USFS provide a report of the aerial reconnaissance with updates on insect and disease trends.

The focus on the Three Creeks Timber Sale Project would include:

- the effects of insects and diseases;

- existing conditions in relation to the project or harvest areas;

- management recommendations; and

- potential losses of sawlog value to the trusts.

Major forest insects and diseases that currently affect forest productivity, structure, and composition within the Three Creeks Timber Sale Project area:

- Armillaria root disease (Armillaria ostoyae)
- White pine blister rust (Cronartium ribicola)

- Larch dwarf mistletoe (Arceuthobium laricis)

- Indian paint fungus (Echinodontium tinctorium)

- Red-brown butt rot (Phaeolus schweinitzii)

- Douglas-fir bark beetle (Dendroctonus pseudotsugae)

- Fir engraver (Scolytus ventralis)

- Red ring rot (Phellinus pini)

(See FIGURE III-1 - DOUGLAS-FIR BEETLE ACTIVITY 2002 THROUGH 2004 IN VICINITY OF THREE CREEK TIMBER SALE PROJECT, ALL ALTERNATIVES COMBINED) on the following page.)

\section{ALTERNATIVE EFFECTS TO INSECTS AND DISEASES}

Direct Effects

\section{- Direct Effects of.NovAction Altermative.A to Insects and Diseases}

Sawlog volume would continue to be lost from inaccessible stands with large trees in the project area due to effects from insects and diseases, especially Douglas-fir bark beetles and Armillaria root disease. Salvage logging would continue where stands are accessible without building roads.

\section{- Direct Effects of Action .Alternatives $\mathrm{B}, \mathrm{C}, \mathrm{D}$, and E to Insects and Diseases}

Harvest treatments would target those species or individuals currently affected by insects and diseases, as well as the salvage of recently killed trees. Douglasfir, recently or currently infested by the Douglas-fir bark beetle, would be removed when merchantable value exists. Western larch with the most severe infections or dwarf mistletoe would be harvested. Other species that would be discriminated against in harvests include grand fir and subalpine fir. By removing green infected trees, the continued spread of the various insects and diseases would be hampered. 
FIGURE III-1 - DOUGLAS-FIR BEETLE ACTIVITY 2002 THROUGH 2004 IN VICINITY OF THREE CREEK TIMBER SALE PROJECT, ALL ALTERNATIVES COMBINED
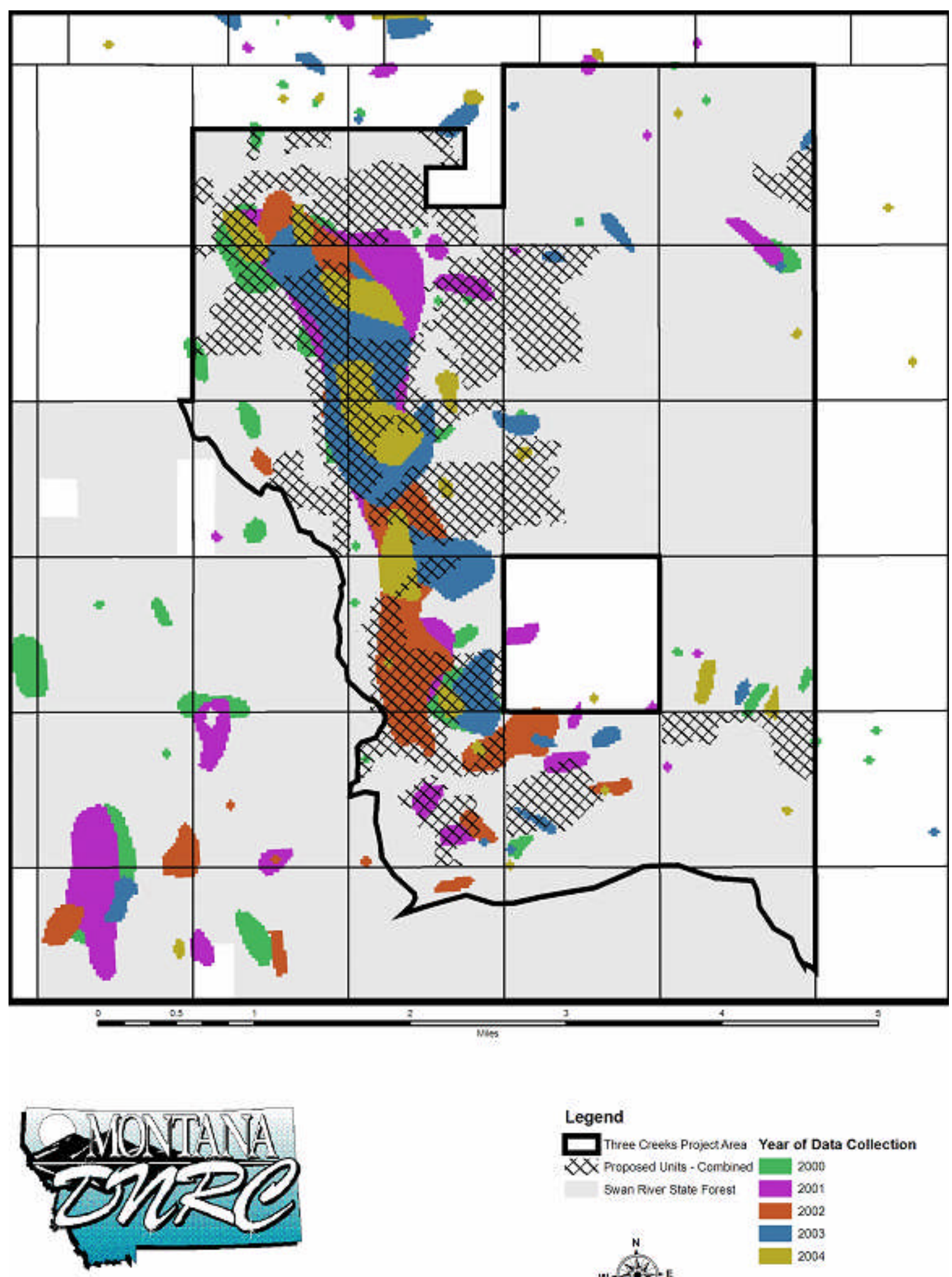

Legend

Three Creeks Projestses Year of Data Collection

XX Proposed units - Combined 2000

Swan River State Forest $\square 001$

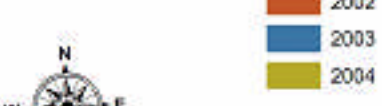

$\sum^{2}+2004$ 
Direct effects of the harvest treatments are the removal of trees affected by insects and diseases, those with reduced growth rates due to age, and shade-tolerant trees that do no help meet desired future conditions. Seedtrees, primarily western larch, would be left scattered throughout harvest units to provide a seed source for natural regeneration.

Insect and disease problems would be reduced following implementation of any action alternative. Action Alternative $B$ does the most to control rates of spread, economic value loss, and volume loss within the project area. The other action alternatives in order of decreasing efficacy in treating insect and disease activities would be Action Alternatives $D, C$, and $E$.

\section{- Direct Effects of .Action. Alternatives B to Insects and Diseases}

Units proposed for harvesting under this alternative are moderately to heavily affected by insect and disease activity. Treatments are focused on those stands with the greatest amounts of mortality and economic value loss.

The majority of the units would be treated with regeneration harvests, though some commercial thinning would be applied. The regeneration would be shade-intolerant species, such as western larch, which are more resistant to many of the infecting agents currently present. This alternatives does the most to address insect and disease problems in the project area.

\section{- Direct Effects of.Action. Alternatives C to Insects and Diseases}

Many of the stands selected for this alternative have insect and disease activity occurring at elevated levels. Emphasis would be placed on trees (groups or individuals) that are affected by insects or diseases, are at risk of infection, or, if dead, contain merchantable material.

Fewer acres receive regeneration harvests with this alternative, reducing the control of insect and disease problems compared to Action Alternative B.

\section{- Direct Effects of Action . Alternatives D to Insects and Diseases}

This alternative proposes harvesting in some stands with moderate to heavy levels of insect and disease problems, although approximately half the stands selected have low levels of insect and disease activities.

The amount of regeneration harvesting would be intermediate between Action Alternatives B and C, with a corresponding intermediate effect on reducing the insect and disease problems.

\section{- Direct Effects of Action .Alternatives E to Insects amd Diseases}

Stands proposed for harvesting have moderate to heavy insect and disease activities and are in the lower elevations of the project area. An objective for this alternative was to limit the amount of old-growth stands that were harvested. In doing so, the stands most affected by insect and disease activities would be avoided. Areas of known beetle populations and diseases would be left untreated. This would allow continued spread of existing insect and disease problems.

The avoidance of many stands with known insect and disease problems results in this alternative having the least effect on reducing the insect and disease problems.

Indirect Effects

\section{- Indirect Effects of. Vo-Action .Altermative A to} Insects and Diseases

School trusts may lose long-term revenue due to:

- increasing mortality rates and 
sawlog defect caused by the ongoing presence of a variety of the aforementioned pathogens;

- reduced growth rates as oldgrowth stands continue to age and defects increase; and

- nonregeneration of high valued species such as western larch and western white pine.

- Indirect Effects of .Action. Alternatives B, C, D, and E to Insects and Diseases

Where shelterwood and commercialthin treatments are applied, the indirect effects would be the increased vigor and growth rates of remaining trees due to the availability of light, nutrients, and moisture. The species composition following treatment would be more resilient to damage by forest diseases and insects.

Under Action Alternative B, the newly established stands would be healthier and would not have an overstory laden with insect and disease activities, which would infect/infest the seedlings. This alternative would treat the most acres with insect and disease problems, which, in turn would lead to healthier forest stands for the future.

Action Alternatives $C$ and D also propose harvesting insect-infested and disease-infected stands. These alternatives would not treat as many acres as Action Alternative $B$, but would have similar effects on the acres treated. Overall, these alternatives would do less than Action Alternative $B$ to address the insect and disease problems prevalent in the project area.

Action Alternative $E$ would do the least to address insect and disease problems in the project area. Treatments in stands currently affected by insect and disease problems would provide benefits to the newly developed stands. Treated stands that do not have current problems may be more resistant to future insect and disease activities. However, the avoidance of know insect and disease hotspots would provide a dissemination source, increasing the future spread of insect and disease problems when compared to the other alternatives.

\section{Cumulative Effects}

- Cumulative Effects of .No-Action Alternative A to Insects and Diseases

No live, dead, dying, or high-risk trees would be harvested. Some insect-infested and diseaseinfected trees would be salvage harvested, but at a slower, less effective rate. Forest stands would maintain dense stocking levels, which contribute to the spread of insects, diseases, and fuel loading, which, in turn, could lead to high-intensity fires, unnatural forest structures, and overall poor health of the stand.

- Cumulative Effects of Action .Atternatives B, C, D, and E to Imsects amd Diseases

Timber-management activities on Swan River State Forest have generally implemented prescriptions meant to reduce losses and recover mortality due to stem rots, bark beetles, white pine blister rust, western larch dwarf mistletoe, blowdown, and other causes. Standregeneration treatments are producing stands with species compositions more resilient to the impacts of forest insects and diseases and more in line with historic forest conditions. Thinning treatments have further reduced the percentage of infected/infested trees. 


\section{FIRE EFFECTS}

The fire regime across Swan River State Forest is variable. The forest displays a mosaic pattern of age classes and covertypes that have developed due to variations in fire frequency and intensity. In areas that have experienced relatively frequent fires, Douglas-fir, western larch, and ponderosa pine covertypes, with a component of lodgepole pine and western white pine, were produced. As fire frequencies become longer in time, shade-tolerant species (grand fir, subalpine fir, Engelmann spruce, western hemlock, western red cedar) have a better chance to develop. Where fire frequencies were short, the stands are open and single storied, occasionally two storied. As fire suppression began, covertypes and fire frequencies were altered. Stands of ponderosa pine, western larch, and/or Douglas-fir have become multistoried with shadetolerant species.

Over the last 25 years, 72 fires have burned on Swan River state Forest. During this period, 15 lightning fires have burned 70.91 acres, with the largest occurring in 1994 during a dry lightning storm; that fire burned 65 acres in the upper subalpine fir habitat types. Lightning causes approximately 72 percent of all fire starts on Swan River State Forest. On average, 2.88 fires per year occur; approximately 2 are from natural events and 1 is man-caused. Mancaused fires are typically started from campfires, debris burning, or incidents directly related to powerline sparks. Within the project area, an average of 1 fire per year occurs and is usually caused by lightning. (Personal communication Allen Branine, 2006).

\section{FIRE GROUPS}

The Three Creeks Timber Sale Project area is primarily represented by 2 different fire regimes that are classified as fire groups: Fire Group 11 (62 percent of the project area) and Fire Group 9 (25 percent of the project area) (Fischer and Bradley, 1987). Five other fire groups are within the project area, but due to minor representation (5 percent or less), these fire groups will not be addressed further.

Fires burned in the project area at intervals of 15 to 200-plus years. The various fire intervals and intensities created a mosaic of stands in the forest across the project area. Management in the project area is attempting to mimic, at least in part, historic fire patterns and intensities.

\section{HAZARDS AND RISKS IN THE PROJECT AREA}

The hazards and risks associated with wildfires include a potential loss of timber resources, effects to watersheds, and loss of property. The majority of timber stands being considered for harvesting are in the mature or older age classes in stands that have not burned since pre-European settlement. Fire hazards in these areas range from above- to near-natural levels with moderate to high accumulations of down and ladder fuels relative to stand densities. Some of the western larch/Douglas-fir stands have a dense understory of grand fir, a significant hazard due to their density and structure, and the increased risk that a low-intensity ground fire could develop into a stand-replacing crown fire.

\section{ALTERNATIVE EFFECTS TO FIRE EFFECTS}

\section{Direct Effects}

\section{- Direct Effects of. VorAction Altermative.A to Fire Effects}

The wildfire hazard would not change substantially in the short term. With continued fuel accumulation from downed woody debris, the potential for wildfires increases. Large scale, standreplacing fires may be the outcome. 


\section{- Direct Effects of Action .Altermatives $\mathrm{B}, C, D$, amd E to Fire Effects}

Immediately following timber harvesting, the amount of fine fuels would increase. Hazards would be reduced by scattering slash, cutting limbs and tops to within a maximum height to hasten decomposition, spot piling by machine in openings created by harvesting, and burning landing piles.

Broadcast burning would be utilized as a site-preparation method in some seedtree units, while others would be treated by simultaneously piling slash and scarifying soil with an excavator, followed by the burning of piles. Both scarification and broadcast burning prepare seedbeds for natural regeneration. Broadcast burning would consume fuels and return nutrients to the soil at a faster rate than unburned areas.

\section{Indirect Effects}

\section{- Indirect Effects of. Vo-Action .Attermative.A to Five Effects}

Eventually, due to the continuing accumulation of fine fuels, snags, ladder fuels, and deadwood components, the risk of standreplacement fires would increase.

\section{- Indirect Effects of Action . Alternatives $\mathrm{B}, \mathrm{C}, \mathrm{D}$, and E to Fire Effects}

The hazards of destructive wildfires in these stands would be reduced because larger, more fireresistant species would be left at wider spacings. Grand fir, some Douglas-fir, western red-cedar, and subalpine fir, which pose a higher crown-fire hazard because of their low growing branches and combustible nature, would be removed. This would reduce the potential mortality from low- to moderate-intensity fires, but would not "fireproof" the stands from the high-intensity stand-replacing fires brought on by drought and wind.

\section{Cumulative Effects}

- Cumalative Effects of. Vo-Action Alternative.A on Five Effects

The risk of wildfires would continue to increase as a result of long-term fire suppression.

- Cumulative Effects of Action Alternatives $\boldsymbol{B}, \boldsymbol{C}$, D, and E on Five Effects

Fuel loading would be reduced in treated stands, decreasing wildfire risks in these specific areas. 


\section{OLD GROWTH}

DNRC defines old growth as stands that meet minimum criteria for number, size, and age of trees per acre for a given combination of covertype and habitat-type group. The definitions are adopted from those presented by Green et al., (1992).

Swan River state Forest currently has 12,478 acres of old growth, which is equal to 32.4 percent of the total acreage. The project area contains 4,483 acres of old growth, which is equal to 42.2 percent of the project area. TABLE III-1 CURRENT OLD-GROWTH ACRES AND

ALTERNATIVE EFFECTS BY FOREST TYPE FOR SWAN RIVER STATE FOREST shOWS the amount of acres in an old-growth status per covertype.

FIGURE III-4 - CURRENT OLD-GROWTH STANDS ON SWAN RIVER STATE FOREST is a map of old growth within the project area. In addition to oldgrowth stands identified by the SLI in the project area, approximately 992 acres of old growth have been field verified.

\section{OLD-GROWTH ATTRIBUTES}

The diversity of old-growth definitions and the relative importance of old growth as a specific stand condition led DNRC to develop a tool to analyze and understand old growth. This tool indexes attribute levels in stands.
The old-growth attributes are:

- number of large live trees,

- amount of coarse woody debris,

- number of snags,

- amount of decadence,

- multistoried structures,

- gross volume, and

- crown density.

\section{ALTERNATIVE EFFECTS TO OLD GROWTH}

\section{Direct Effects}

\section{- Direct and Indirect Effects of. No Iction -Alternative. A to Old Growth}

In the short term, existing oldgrowth stands would continue to experience substantial mortality of large Douglas-fir trees, increasing snags, and down woody debris in those stands. Some stands may no longer be in the old-growth classification as a result of the gradual or sudden loss of many large trees due to Douglas-fir bark beetles, mountain pine beetles, dwarf mistletoe, drought, competition, etc. These factors can reduce the number of large, live trees below the minimum described in Green et al (1992). Over the long term, existing old growth would continue to age and become more decadent.

\section{- Direct Effects of Action .Alternatives B, C, D, and E' to Old Growth}

The proposed harvest treatments for all of the action alternatives would affect old growth. Old-

TABLE III-1 - CURRENT OLD-GROWTH ACRES AND ALTERNATIVE EFFECTS BY FOREST TYPE FOR SWAN RIVER STATE FOREST

\begin{tabular}{|c|c|c|c|c|c|}
\hline \multirow{3}{*}{$\begin{array}{c}\text { OLD-GROWTH } \\
\text { TYPE }\end{array}$} & \multirow{3}{*}{$\begin{array}{c}\text { OLD-GROWTH } \\
\text { ACRES }\end{array}$} & \multicolumn{4}{|c|}{ POSTHARVEST } \\
\hline & & \multicolumn{4}{|c|}{ ACTION ALTERNATIVE } \\
\hline & & B & $\mathbf{C}$ & D & $\mathbf{E}$ \\
\hline Douglas-fir & 8 & 8 & 8 & 8 & 8 \\
\hline Western larch/Douglas-fir & 1,830 & 1,968 & 1,901 & 1,960 & 1,710 \\
\hline Western white pine & 2,016 & 2,016 & 2,016 & 2,016 & 2,016 \\
\hline Mixed conifer & 6,926 & 6,253 & 6,397 & 6,200 & 6,699 \\
\hline Subalpine fir & 1,114 & 1,114 & 1,114 & 1,114 & 1,114 \\
\hline Lodgepole pine & 0 & 0 & 0 & 0 & 0 \\
\hline Ponderosa pine & 584 & 584 & 584 & 584 & 584 \\
\hline Totals & 12,478 & 11,943 & 12,020 & 11,882 & 12,131 \\
\hline
\end{tabular}


FIGURE III-4 - CURRENT OLD-GROWTH STANDS ON SWAN RIVER STATE FOREST (STANDS PROPOSED FOR HARVESTING ARE HIGHLIGHTED IN BLUE)

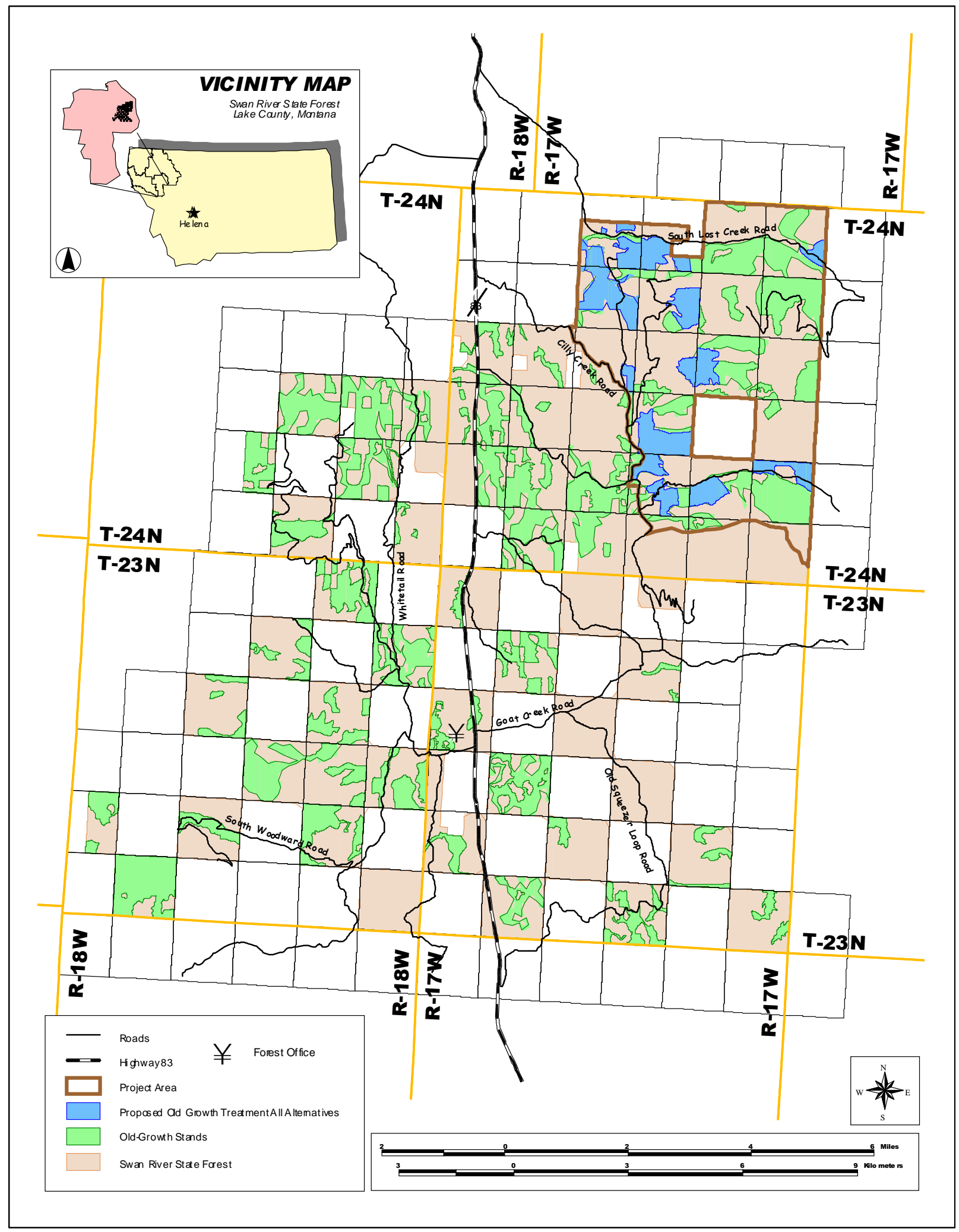


growth stands would be harvested with seedtree, seedtree-withreserves, shelterwood, and commercial-thin treatments. The main objectives for entering these old-growth stands are to remove insect-infested and diseaseinfected trees, maintain historical covertypes, and remove or reduce shade-tolerant species.

The primary effects to old growth would be to remove stands from the old-growth classification or reduce attribute levels associated with old-growth stands. The old-growth attributes that would be affected include:

- Stocking levels in all treated stands would be reduced.

- Stand vigor would improve or remain at existing levels for harvested stands.

- Stand structure in seedtree, seedtree-with-reserves, and shelterwood units would be reduced to single- or two-storied stand structures following harvesting. Commercial-thin units would be reduced to two- and three-storied (multistoried) stand structures following harvesting.

- The minimum snag requirements of 2 trees per acre would be maintained.

- Slash would be piled and burned or otherwise treated on site.

- Large, live trees would be removed.

\section{Indirect Effects}

\section{- Imdirect Effects of. VorAction .Altermative. A to} Old Growth

Over time and barring large-scale disturbances, old-growth attribute levels would increase on most covertypes as climax species mature, decadence increases, and trees die and fall, creating more snags and large woody debris. However, the large-tree component is likely to be reduced over time as large shade-intolerant species die and are replaced by smaller shade-tolerant species with a lesser chance of becoming large.

These same stands would also reach a point where the old-growth attribute levels decrease. As large trees continue to age and eventually die, some stands would no longer meet the old-growth definition.

\section{- Indirect Effects of Action .Alternatives B, C, D, and E to Old Growth}

Timber would be harvested in or near old-growth stands and create more abrupt stand edges. Some mature stands not yet classified as old growth could be considered old growth in the future. Commercialthin harvesting within these mature stands would increase the diameter growth rates of remaining trees and, in some cases, may hasten the development of old-growth attributes, especially in largediameter trees.

\section{Cumulative Effects}

\section{- Cumulative Effects to Old Growth Common to All.Alternatives}

Swan River State Forest's salvage program has completed limited harvesting in old growth on the High Blow '02 Salvage and Big Blowdown Salvage timber sales. Currently, the Cilly Bug, Rock Squeezer, and Red Ridge timber sales are harvesting in designated old-growth stands.

Action Alternative $B$ would harvest approximately 1,221 acres of old growth in the project area, which would reduce the amount of oldgrowth acres in the project area by 12.6 percent. The amount of old growth remaining on Swan River State Forest would be 11,914 acres, and the proportion of acreage classified as old growth would be 30.9 percent.

Action Alternative $\mathrm{C}$ would harvest approximately 1,122 acres of old growth in the project area, which would reduce the amount of old- 
growth acres in the project area by 10.4 percent. The amount of oldgrowth acres remaining on Swan River State Forest would be 12, 012 acres, and the proportion of acreage classified as old growth would be 31.2 percent.

Action Alternative $D$ would harvest approximately 1,143 acres of old growth in the project area, which would reduce the amount of oldgrowth acres in the project area by 13.3 percent. The amount of old growth remaining on Swan River State Forest would be 11,854 acres, and the proportion of acreage classified as old growth would be 30.8 percent.

Action Alternative $E$ would harvest approximately 446 acres of old growth in the project area, which would reduce the amount of oldgrowth acres in the project area by 7.7 percent. Swan River State Forest would contain 12,131 acres of old growth; the proportion of acreage classified as old growth would be 31.5 percent.

Recognizing that the amounts and distributions of all age classes would shift and change over time, the amount of old growth remaining is within an expected range of natural variation.

\section{AGE AND COVERTYPE PATCH SIZES}

Age-class and covertype patches broadly reflect disturbance in the natural environment and the additional influence of harvesting and associated activities in the managed environment. Tracking the changes from historical to current conditions can indicate the effects of management and whether the direction of change is desirable. DNRC has maps of an inventory conducted in the 1930 s that provide a general baseline for age (and covertype) patches for Swan River State forest and the project area. The data does not provide for a seamless comparison between historic and current conditions due to differences in mapping procedures, primarily an eight-fold difference in minimum map-unit size (40 acres historically and 5 acres currently). The reduced minimum-map unit size results in many more patches of a smaller average size, even when applied to the same forest at the same point in time. However, the data does represent the best historic information available; therefore, the data is presented with the caveats mentioned in this paragraph.

The following age classes were defined: 0-to-39, 40-to-99, 100-to150, and $150+$. The oldest age class also encompasses all old-growth stands; however, old growth would represent only a portion of all 150+-year-old stands since not all of the stands would meet the largetree requirements that are part of DNRC's old-growth definitions. Reconstructing the historic data to quantify patch characteristics of old growth is not possible, and, so, comparisons between historic and current conditions are not made. An analysis of the current patch characteristics of old growth and the effects of each action alternative is presented in APPENDIX C - VEGETATION ANALYSIS.

Historic data indicates that $150+-$ year-old patches were very large in both Swan River state Forest and the project area, with the patches being much larger in the project area than for the entire Swan River state Forest. Other age patches were variable in size between the project level and Swan River state Forest. On average, current age-class patches are much smaller than historically. Some of the decrease can be attributed to different mapunit minimums, but the data likely reflects a real reduction in mean patch sizes, as harvesting and roads have broken up some previously intact patches.

Current 150+-year-old patches are much smaller at the scale of Swan 
River state forest than they were historically. The 150+-year old patches in the project area are larger than the historic mean for Swan River State Forest, but are approximately one-third the size of historic patches in the project area. At the scales of both the project area and Swan River state Forest, all other age patches are smaller currently than historically.

\section{Covertype Patches}

Historic data suggests mean covertype patch sizes are similar to age patch sizes. As with mean ageclass patch sizes, the differences in mapping protocols and, in particular, a different minimum mapunit size confound direct comparison and drawing clear conclusions.

However, a real decrease in the mean covertype patch size is expected due to the effects of harvesting and road building. The effects of succession confound the results and are reflected in the increased patch size of shade-tolerant types (mixedconifer and subalpine types).

Overall, current covertype patches on Swan River state Forest and the project area are about one-third the size of the historic mean.

Currently, the project area covertype patches tend to be larger than for Swan River state Forest.

\section{Alternative Effects on Age and Covertype Patch Sizes}

Direct and Indirect Effects

- Direct and Indirect Effects of. Vo-oction -Alternative. $A$ on . Age and Covertype Patch Sizes

Patch sizes would not be immediately affected. Over time, the forest would tend to homogenize, leading to larger patches of older stands, especially in the absence of significant fires or other disturbance events.

\section{- Direct and Indirect Effects of .All.Action -Alternatives on .Age and Covertype Patch Sizes}

Within the project area, the mean old-stand patch size would be reduced to about one-half of current means with all action alternatives. Action Alternative B would reduce old-stand patch size the most, with the other action alternatives being roughly equivalent. Other age patches would be only marginally affected, except the 0-to-39-year-old class, where mean patches would be increased with each action alternative, which reflects the effort to group stand-replacement harvesting near other previously harvested areas.

Compared to current conditions, project-level effects indicate that Action Alternatives B, C, and E would slightly increase the mean size of age patches, while Action Alternative D would slightly decrease the mean.

\section{Cumulative Effects}

\section{- Cumulative Effects of All Alternatives om . Age and Covertype Patch Sizes}

The current age-class patch condition reflects the effects of natural disturbances and succession and the cumulative effects of previous activities by DNRC that have been completed and mapped. Overall, age patches for the entire forest and the project area are reduced from historic to current conditions.

\section{OLD-GROWTH PATCHES}

Old growth represents a subset of the old-stand age class. This analysis displays current patch-size characteristics of old growth and the effects of each alternative. This analysis does not present a corresponding analysis of historical old-growth patch characteristics because the data does not exist. The reductions in patch size of oldage stands are expected to reflect a 
similar reduction in the patch size of old-growth stands, but the absolute magnitude is unknown.

Currently, the mean patch size of old-growth stands on Swan River State Forest is 123.5 acres. Within the project area, the mean oldgrowth patch size is 344.9 acres. Old-growth patches are about onethird to one-half the mean size of old-stand patches.

\section{Direct and Indirect Effects}

\section{- Direct and Imdirect Effects of -Vo-action} -Altermative. A on Old-Growth Patches

The patch size of old-growth stands would not be immediately affected. Over time, the effects to oldgrowth patch size would be uncertain because it would depend on the development of large live trees within old-age stands and because current insect infestations and disease infections are killing many large trees, causing the stands to fall out of the oldgrowth classification.

\section{- Divect and Indivect Effects of.All.Action -Alternatives on Old-Growth Patches}

Each action alternative would reduce the mean patch size of old growth within the project area. Action Alternative $\mathrm{D}$ would reduce the mean patch size of old growth the most (by 189.6 acres), while Action Alternative $\mathrm{E}$ would reduce it the least (by 132.6 acres). Action Alternative $\mathrm{D}$ would result in the largest decrease (19.4 acres), while Action Alternative E would result in the smallest decrease (11.1 acres), with the other alternatives intermediate in their decrease.

\section{Cumulative Effects}

\section{- Cumulative Effects of All Altermatives on Old-} Growth Patches

The current old-growth-patch condition reflects the effects of natural disturbance and succession and the cumulative effects of previous activities by DNRC that have been completed and mapped. Overall, old-growth patches for the entire forest and the project area are likely reduced from historic to current conditions. Other ongoing projects have not entered oldgrowth stands. Within the project area, cumulative effects of other harvests have been incorporated into the Effects Analysis.

\section{COVERTYPE PATCHES}

Historic data suggests mean covertype patch sizes are similar to age patch sizes, in part, due to the single large patch of old western larch/Douglas-fir that dominated the forest and project area. However, a real decrease in mean covertype patch size is expected due to the effects of harvesting and road building.

Overall, current covertype patches on Swan River State Forest and the project area are about one-third the size of the historic mean.

Currently, the project area covertype patches tend to be larger than for the forest.

\section{Alternative Effects on Covertype Patches}

Direct and Indirect Effects

\section{- Divect and Indivect Effects of. Vo-.Action -Alternative. I on Covertype Patches}

The covertype patch sizes would not be immediately affected; however, over time, diversity of habitats in terms of covertype patches would likely be reduced through forest succession. The result would be an increase in the mean size of patches dominated by shade-tolerant species as shade-intolerant species are excluded.

\section{- Direct and Indirect Effects of.All.Action -Alternatives on Covertype Patches}

Each action alternative would slightly reduce the average covertype patch size. Action Alternative $D$ would reduce the mean patch size the most, Action 
Alternative $\mathrm{E}$ the least. The greatest changes in covertype patch sizes would occur within two types, the mixed-conifer and the western larch/Douglas-fir patches. The mixed-conifer patches would be reduced in size with each alternative, Action Alternative B the most and Action Alternative $\mathrm{E}$ the least. The western larch/Douglas-fir patches would be increased in size with each alternative, Action Alternative C the most and Action Alternative D the least. Other covertype patch sizes would only be affected marginally or not at all by the project.

Cumulative Effects

\section{- Cumulative Effects of All.Altermatives on Covertype Patches}

The current covertype patch condition reflects previous activities by DNRC and natural disturbances and succession that have been completed and mapped. Overall, covertype patch sizes have been reduced from historic to current conditions.

\section{SENSITIVE PLANTS}

A research was made of the Montana Natural Heritage Program (MNHP) database

(http://www.nhp.nris.mt.gov) in May 2003 for plant species and the habitat that would support these plants in the vicinity of Swan River State Forest. Botanists were contracted to perform a sitespecific survey for sensitive plants within the project area. Results of this search were compared to the location of proposed harvest sites for potential direct and indirect impacts and the need for mitigation measures. The survey identified 9 species of special concern, existing within a total of 19 separate populations (Pierce and Barton 2003); none of these plant populations are within the project area.

\section{Alternative Effects to Sensitive Plants}

Direct and Indirect Effects

\section{- Direct and Indirect Effects of.All.Action} -Alternatives to Sensitive Plants

No effects are expected because no populations of sensitive plants occur within the project area.

\section{Cumulative Effects}

\section{- Cumulative Effects of.All.Action. Alternatives to Sensitive Plants}

If changes in the water yield or nutrient level occur, sensitive plant populations may, in turn, be affected. Given the level of the proposed and active harvesting on Swan River State Forest and other land in the project area, no measurable changes in water yield or surface water levels are anticipated from any of the proposed action alternatives. No change in nutrient levels would occur due to mitigation measures that are designed to prevent erosion and sediment delivery.

\section{NOXIOUS WEEDS}

Spotted knapweed (Centaurea mauclosa Lam.), orange hawkweed (Hieracium aurantiacum), and common st. Johnswort (Hypericum perforatum L.) have become established along road edges within the project area. Swan River state Forest has begun a program to reduce the spread and occurrence of noxious weeds.

\section{Alternative Effects to Noxious Weeds}

Direct and Indirect Effects

\section{- Direct and Indirect Effects of.No-Action -Attermative.A to . Voxious Weeds}

Noxious weed populations would continue as they exist. Weed seed would continue to be introduced by recreational use of the forest and log hauling and other logging activities on adjacent ownerships. Swan River state Forest may initiate spot spraying under the FI 


\section{VEGETATION ANALYSIS SUMMARY}

program to reduce the spread of noxious weeds.

\section{- Direct amd Indirect Effects of.All.Action -Atternatives to. .Voxious Weeds}

Logging disturbance would provide opportunities for increased establishment of noxious weeds; log hauling and equipment movement would introduce seeds from other sites. The spread of existing or new noxious weeds would be reduced by mitigation measures in the form of integrated weed-management techniques. Grass seeding of new and disturbed roads and landings and spot spraying of new infestations would reduce or prevent the establishment of new weed populations.

\section{Cumulative Effects}

- Cumulative Effects of.No-.Action .Alternative.A to. Voxious Weeds

Salvage logging on state land and logging activities on adjacent lands would continue to provide opportunities for noxious weeds to become established. Current population levels would continue to exist and may increase over time.

\section{- Cumulative Effects of All Actiom Altermatives} to.Noxious Weeds

The action alternatives, together with other management and recreational activities on Swan River state Forest, would provide an opportunity for the transfer of weed seed and increased establishment of noxious weeds. Preventative actions by the Lake County Weed Board and active weedmanagement activities performed by Swan River state Forest would reduce the spread and establishment of noxious weeds, as well as the impacts resulting from the replacement of native species. 


\section{INTRODUCTION}

The environment affected by the proposed Three Creeks Timber Sale Project relating to hydrology includes the South Fork Lost Creek, Cilly Creek and Soup Creek watersheds and all of their tributaries. Analysis methods used to evaluate the existing conditions and assess the potential impacts to hydrology include an inventory of sediment sources, an assessment of channel stability, and a computer modeling of annual water yield.

\section{EXISTING CONDITIONS}

\section{Montana Surface Water-Quality Standards}

According to $A R M$ 17.30.608 (2) (a), the Swan River drainage, including South Fork Lost, Cilly, and Soup creeks, is classified as B-1. For a description of criteria associated with B-1 waterbodies, refer to APPENDIX D - WATERSHED AND HYDROLOGY ANALYSIS. Designated beneficial water uses within the project area include cold-water fisheries and recreational use in the streams, wetlands, lake, and surrounding area. The Cilly Creek watershed has domestic water use and irrigation water rights as beneficial uses.

\section{Water-Quality-Limited Waterbodies}

No stream in the proposed project area is currently listed as a waterquality-limited waterbody in the 1996, 2002, or 2004 Montana 303 (d) list. Swan Lake is currently listed on the 2004 Montana 303 (d) list, but was not listed in the 1996 list. For a description of criteria associated with water-qualitylimited waterbodies, refer to APPENDIX D - WATERSHED AND HYDROLOGY ANALYSIS.

The Swan Lake Watershed Group and its associated Swan Lake Technical Advisory Group developed a waterquality restoration plan for Swan Lake in June 2004. The Water Quality Restoration Plan was approved by the Environmental Protection Agency (EPA) in August 2004, and activities are ongoing to correct current sources and causes of sediment to Swan Lake and its tributaries. DNRC is an active partner and participant in this process. All proposed activities within the project area would implement activities to alleviate identified sources of sediment and comply fully with all Total Maximum Daily Load (TMDL) requirements.

\section{Montana SMZ Law}

By the definition in ARM 36.11.312 (3), the majority of the South Fork Lost Creek, Cilly Creek, and Soup Creek watersheds are class 1 streams. All of these streams and many of their tributaries flow for more than 6 months each year. Many of these stream reaches also support fish. Some of the smaller first-order tributaries may be classified as class 2 or 3 based on site-specific conditions.

\section{> SEDIMENT DELIVERY}

\section{$>$ South Fork Lost Creek}

Based on field reconnaissance from 2003 through 2005, stream channels in the South Fork Lost Creek watershed are primarily in good to fair condition. One reach was rated in poor condition and is located on and around the section line between Sections 2 and 3 where USFS lands are intermixed with DNRC-managed lands. The reach represents less than 5 percent of the total length of streams in the watershed and is located on both DNRC-managed and Flathead National Forest (FNF) lands. The primary reason for the rating of poor stability is a midchannel gravel bar that is a result of debris jams.

No areas of down-cut channels were identified during field reconnaissance. Large woody 
debris was found in adequate supply to support channel form and function. Little evidence of past streamside harvesting was found; where past harvesting took place in the riparian area, no deficiency of existing or potential down woody material was apparent in the streams.

\section{$>$ Cilly Creek}

Based on field reconnaissance from 2003 through 2005, stream reaches in the Cilly Creek watershed were rated in good to fair condition. Cilly Creek flows perennially in most reaches, but flow becomes subsurface during the summer and fall in some low-gradient reaches in the valley bottom.

No areas of down-cut channels were identified during field reconnaissance. Large woody debris was found in adequate supply to support channel form and function. Little evidence of past streamside harvesting was found; where past harvesting took place in the riparian area, no deficiency of existing or potential down woody material was apparent in the streams.

\section{$>$ Soup Creek}

Based on field reconnaissance from 2003 through 2005, stream channels in the Soup Creek watershed were primarily in good to fair condition. An unnamed tributary to soup Creek had reaches in the lower elevations rated in poor condition. This reach represents less than 3 percent of the total length of streams in the watershed. The primary reason for the poor rating is a gully cutting through an alluvial fan.

No areas of down-cut channels were identified during field reconnaissance. Large woody debris was found in adequate supply to support channel form and function. The lower reaches of the watershed flow through a series of wetlands and beaver ponds. The beaver dams can lead to changing water levels in the stream, but the wetlands and beaver ponds tend to moderate the high runoff periods and settle out sediment and channel bed materials that may be carried downstream during runoff. Past management of streamside stands occurred in the lower reaches of the watershed. Where past logging took place in the riparian area, no deficiency of existing or potential downed woody material was apparent in the stream.

\section{Road System}

Based on the sediment-source review conducted for the Swan Lake TMDL, several existing sources of sediment were identified on the existing road system. Each of the sources identified in this analysis is either found on DNRC-managed ownership or is associated with roads that are under a CostShare Agreement entered into by DNRC and FNF. Most of the sediment delivery sites are located at stream crossings, but a portion of the South Fork Lost Creek road system was also identified as a chronic source of sediment delivery to south Fork Lost Creek, with over 0.5 mile of road capable of delivering sediment to the stream. Another site that was found to contribute large volumes of sediment is located in the Soup Creek canyon. The east road approach to a decaying wooden bridge is on a steep grade and has no surfacedrainage relief, making it a chronic source of sediment delivery. 
The total estimated sediment delivery from roads in the project area to South Fork Lost, Cilly, and soup creeks are displayed in TABLE III-1 ESTIMATED SEDIMENT DELIVERY TO STREAMS FROM THE EXISTING ROAD SYSTEM. These sediment-delivery values are estimates based on procedures outlined in APPENDIX $D$ - WATERSHED AND HYDROLOGY and are not measured values.

TABLE III-1 - ESTIMATED SEDIMENT DELIVERY TO STREAMS FROM THE EXISTING ROAD SYSTEM

\begin{tabular}{|l|c|c|c|}
\hline & $\begin{array}{c}\text { SOUTH FORK } \\
\text { LOST CREEK }\end{array}$ & $\begin{array}{c}\text { CILLY } \\
\text { CREEK }\end{array}$ & $\begin{array}{c}\text { SOUP } \\
\text { CREEK }\end{array}$ \\
\hline $\begin{array}{l}\text { Existing tons } \\
\text { per year }\end{array}$ & 19.8 & 2.9 & 35.6 \\
\hline
\end{tabular}

South Fork Lost Creek has 2 wooden bridges with log crib abutments that were constructed in the 1960s; the wood is very rotten and the bridge decking has started to collapse. These 2 sites are not yet a major source of sediment in the watershed, but the bridges are a high risk of failure due to the decay of the wood. Each abutment is supporting 8 to 10 tons of fill material that would be washed down the creek should they fail.

In the Soup Creek watershed, 5 old crossing sites are a high risk for sediment delivery to Soup Creek. Two of these sites consist of dirt fill material over logs spanning the creek and may contribute minor amounts of sediment to the stream during high runoff. Due to the decay of the wood, both bridges are high risks of failure. Should either or both of these structures fail, most, if not all, of the 35 tons and 500 tons of material would be delivered to the stream. A wooden bridge in the Soup Creek canyon is constructed of $\log$ crib abutments and is very decayed.
Each abutment is supporting 8 to 10 tons of fill material that would be washed down the creek should they fail.

Two additional old bridge sites exist in the lower reaches of the Soup Creek watershed. Each bridge abutment is supporting 8 to 10 tons of fill material that would be washed down the creek should they fail.

Other sources of sediment delivery found during the inventory are located on sites needing additional erosion control and BMP upgrades. These sites occur on older roads that were constructed before the adoption of forest management BMP s .

Much of the existing road system in the proposed project area meets applicable BMPs.

\section{WATER YIELD}

Based on channel-stability evaluations, watershed sensitivity, and acceptable risk, the allowable increase in wateryield has been set at 10 percent for the South Fork Lost Creek watershed; 11 percent for the Cilly Creek watershed; and 9 percent for the Soup Creek watershed. Past timber harvesting, combined with the vegetative recovery that has occurred, has led to an estimated 1.2-percent water-yield increase over an unharvested condition in the South Fork Lost Creek watershed, 2.3 percent over an unharvested condition in Cilly Creek, and 1.0 percent over an unharvested condition in Soup Creek. TABLE III-2 - CURRENT WATER-YIELD AND EQUIVALENT CLEARCUT ACRES (ECA) INCREASES IN THREE CREEKS PROJECT AREA summarizes the existing conditions for water yield in the project area watersheds. 
TABLE III-2 - CURRENT WATER-YIELD AND EQUIVALENT CLEARCUT ACRES

(ECA) INCREASES IN THREE CREEKS PROJECT AREA

\begin{tabular}{|l|c|c|c|}
\hline & $\begin{array}{c}\text { South Fork } \\
\text { Lost Creek }\end{array}$ & $\begin{array}{c}\text { Cilly } \\
\text { Creek }\end{array}$ & $\begin{array}{c}\text { Soup } \\
\text { Creek }\end{array}$ \\
\hline Existing $\div$ water-yield increase & 1.2 & 2.3 & 1.0 \\
\hline Allowable $\div$ water-yield increase & 10 & 11 & 9 \\
\hline
\end{tabular}

\section{ALTERNATIVE EFFECTS}

\section{SEDIMENT DELIVERY}

\section{Direct and Indirect Effects}

\section{- Direct amd Imdirect Effects of. No-atction -Atternative A to Sediment Delivery}

No-Action Alternative A would have no direct effects to sediment delivery beyond those currently occurring. Indirect effects would be an increased risk of sediment delivery to streams from crossings that do not meet applicable BMPs.

\section{- Direct and Indirect Effects to Sediment Delivery Common to .Action . Alternatives B, C, D and E}

Each of the proposed action alternatives would replace the wooden bridge over Soup Creek on the Soup Creek Canyon Road and install surface drainage to the road. These improvements would lead to a decrease in delivery of approximately 23.8 tons of sediment per year at this site.

Each action alternative would also permanently remove and rehabilitate 2 log-and-earth-fill crossings in the upper reaches of Soup Creek, permanently remove and rehabilitate an old wooden bridge in the lower portion of the Soup Creek watershed, permanently remove and rehabilitate 2 old wooden bridges on South Fork Lost Creek, and permanently remove and rehabilitate the abutments and fill from the original Swan Highway bridge in the lower reaches of Soup Creek. Each of these 4 sites contains 16 to 20 tons of fill material ( 8 to 10 tons behind each abutment). Removal and disposal of this material outside of the SMZ would remove the risk of this material being delivered to Soup Creek and Swan River.

Removal and rehabilitation of the 2 log/earth crossings in the upper Soup Creek canyon would remove 500 to 600 tons of potential sediment to Soup Creek.

Relocation and rehabilitation of the South Fork Lost Road would reduce the estimated sediment delivery to South Fork Lost Creek by approximately 18.9 tons per year from the existing condition.

At each site there would be a short-term increase in the risk of sediment delivery at rehabilitated sites. This risk would decrease within 2 to 3 years to below preproject levels as bare soil revegetates. The rehabilitation activity would produce some direct sediment delivery, but this would be minimized through the application of sediment-control measures as prescribed by a DNRC hydrologist and fisheries biologist and a DFWP fisheries biologist.

\section{- Direct and Indirect Effects of.Action -Altermative B to Sediment Delivery}

Improvements to approximately 47 miles of existing road and construction of 13 miles of new road and 5.3 miles of temporary road would:

- decrease the estimated sediment load to South Fork Lost Creek by an additional 0.4 tons of sediment beyond the reduction shown in Effects Common to Action Alternatives $B, C, D$, and $E$, for a total reduction of approximately 19.3 tons of sediment per year; 
- reduce the estimated sediment load to Cilly Creek by approximately 1.0 ton per year; and

- reduce the estimated sediment load to Soup Creek by an additional 9.8 tons of sediment beyond the reduction shown in Effects Common to Action Alternatives $B, C, D$, and $E$, for a total reduction of approximately 33.6 tons per year.

These projected sediment reductions are net values for each watershed. These values include the projected increases in sediment delivery from new stream crossings and new road construction. A more detailed summary of sediment delivery estimates is found in TABLE III-3 (4, 5) - ESTIMATES OF SEDIMENT DELIVERY IN SOUTH FORK LOST CREEK (CILLY CREEK, SOUP CREEK) WATERSHED.

Harvesting activities are proposed within the South Fork Lost Creek and Cilly Creek SMZs. These activities would follow all requirements of the SMZ Law and the Rules and would have a low risk of affecting channel stability and sediment transport through reduced recruitment of large woody material to South Fork Lost Creek, Cilly Creek, or their tributaries. A more in-depth discussion of the impacts of riparian harvesting can be found in APPENDIX E - FISHERIES ANALYSIS.

\section{- Direct and Indirect Effects of Actiom -Atternative C to Sediment Delivery}

Improvements to approximately 65 miles of existing road and construction of 12.4 miles of new road and 6.9 miles of temporary road would:

- decrease the estimated sediment load to South Fork Lost Creek by an additional 0.4 tons of sediment beyond the reduction shown in Effects Common to Action
Alternatives $B, C, D$, and $E$, for a total reduction of approximately 19.3 tons of sediment per year;

- reduce the estimated sediment load to Cilly Creek by approximately 1.0 ton per year; and

- reduce the estimated sediment load to soup Creek by an additional 9.8 tons of sediment beyond the reduction shown in Effects Common to Action Alternatives $B, C, D$, and $E$, for a total reduction of

approximately 33.6 tons per year.

These projected sediment reductions are net values for each watershed. These values include the projected increases in sediment delivery from new stream crossings and new road construction. A more detailed summary of sediment delivery estimates is found in TABLE III-3 $(4,5)$ - ESTIMATES OF SEDIMENT DELIVERY IN SOUTH FORK LOST CREEK (CILLY CREEK, SOUP CREEK) WATERSHED.

Harvesting activities are proposed within the South Fork Lost Creek and Cilly Creek SMZs. These activities would follow all requirements of the SMZ Law and the Rules, and would have a low risk of affecting channel stability and sediment transport through reduced recruitment of large woody material to South Fork Lost Creek, Cilly Creek, or their tributaries. A more in-depth discussion of the impacts of riparian harvesting can be found in APPENDIX E - FISHERIES ANALYSIS. 


\begin{tabular}{|c|c|c|c|c|c|}
\hline \multicolumn{6}{|c|}{ WATERSHED AND HYDROLOGY SUMMARY } \\
\hline \multicolumn{6}{|c|}{$\begin{array}{l}\text { TABLE III-3 - ESTIMATES OF SEDIMENT DELIVERY IN THE SOUTH FORK LOST } \\
\text { CREEK WATERSHED }\end{array}$} \\
\hline & \multicolumn{5}{|c|}{ ALTERNATIVE } \\
\hline & $\mathbf{A}$ & B & $\mathbf{C}$ & $\bar{D}$ & $\mathbf{E}$ \\
\hline $\begin{array}{l}\text { Existing delivery (tons/ } \\
\text { year) }\end{array}$ & 19.8 & 19.8 & 19.8 & 19.8 & 19.8 \\
\hline Estimated reduction ${ }^{2}$ & 0.0 & 19.3 & 19.3 & 19.3 & 19.3 \\
\hline Estimated increase ${ }^{3}$ & 0.0 & 0.0 & 0.0 & 0.6 & 0.6 \\
\hline $\begin{array}{l}\text { Post-project delivery } \\
\text { (tons/year) }\end{array}$ & 19.8 & 0.5 & 0.5 & 1.1 & 1.1 \\
\hline Reduction (tons/year) & 0 & 19.3 & 19.3 & 18.7 & 18.7 \\
\hline Percent reduction ${ }^{4}$ & 0 & $97 \%$ & $97 \%$ & $94 \div$ & $94 \%$ \\
\hline
\end{tabular}

TABLE III-4 - ESTIMATES OF SEDIMENT DELIVERY IN THE CILLY CREEK WATERSHED

\begin{tabular}{|l|c|c|c|c|c|}
\hline & \multicolumn{4}{|c|}{ ALTERNATIVE } \\
\cline { 2 - 6 } & A & B & C & D & E \\
\hline $\begin{array}{l}\text { Existing delivery (tons/ } \\
\text { year) }\end{array}$ & 2.9 & 2.9 & 2.9 & 2.9 & 2.9 \\
\hline Estimated reduction ${ }^{2}$ & 0.0 & 1.4 & 1.4 & 1.4 & 1.4 \\
\hline Estimated increase & 0.0 & 0.4 & 0.4 & 0.8 & 0.4 \\
\hline $\begin{array}{l}\text { Postproject delivery } \\
\text { (tons/year) }\end{array}$ & 2.9 & 1.9 & 1.9 & 2.3 & 1.9 \\
\hline Reduction (tons/year) & 0 & 1.0 & 1.0 & 0.6 & 1.0 \\
\hline Percent reduction & 0 & $34 \%$ & $34 \%$ & $21 \%$ & $34 \%$ \\
\hline
\end{tabular}

TABLE III-5 - ESTIMATES OF SEDIMENT DELIVERY IN THE SOUP CREEK WATERSHED

\begin{tabular}{|c|c|c|c|c|c|}
\hline & \multicolumn{5}{|c|}{ ALTERNATIVE } \\
\hline & $\mathbf{A}$ & B & C & D & $\mathbf{E}$ \\
\hline $\begin{array}{l}\text { Existing delivery (tons/ } \\
\text { year) }\end{array}$ & 35.6 & 35.6 & 35.6 & 35.6 & 35.6 \\
\hline Estimated reduction ${ }^{2}$ & 0.0 & 34.3 & 34.3 & 34.3 & 34.3 \\
\hline Estimated increase ${ }^{3}$ & 0.0 & 0.7 & 0.7 & 0.7 & 0.4 \\
\hline $\begin{array}{l}\text { Postproject delivery } \\
\text { (tons/year) }\end{array}$ & 35.6 & 2.0 & 2.0 & 2.0 & 1.7 \\
\hline Reduction (tons/year) & 0 & 33.6 & 33.6 & 33.6 & 33.9 \\
\hline Percent reduction ${ }^{4}$ & 0 & $95 \%$ & $95 \%$ & $95 \%$ & $95 \%$ \\
\hline
\end{tabular}

${ }^{1}$ These sediment-delivery values are estimates based on procedures outlined in Analysis Methods, and are not measured values.

${ }^{2}$ Includes projected decreases from rehabilitation and BMP work on existing roads and crossings.

${ }^{3}$ Includes projected increases from construction of new roads and new stream crossings.

${ }^{4}$ Percent reduction values are estimates based on procedures outlined in Analysis Methods, not on measured values. 


\section{- Direct and Indirect Effects of.Action -Alternative D to Sediment Delivery}

Improvements to approximately 84 miles of existing road and construction of 15.6 miles of new road and 3.9 miles of temporary road would:

- Reduce the total estimated sediment load by approximately 18.7 tons per year;

- reduce the estimated sediment load to Cilly Creek by approximately 0.6 ton per year; and

- reduce the estimated sediment load to Soup Creek by an additional 9.8 tons of sediment beyond the reduction shown in Effects Common to Action Alternatives $B, C, D$ and $E$, for a total reduction of approximately 33.6 tons per year.

These projected sediment reductions are net values for each watershed. These values include the projected increases in sediment delivery from new stream crossings and new road construction. A more detailed summary of sediment-delivery estimates is found in TABLE III-3 (4, 5) - ESTIMATES OF SEDIMENT DELIVERY IN SOUTH FORK LOST CREEK (CILLY CREEK, SOUP CREEK) WATERSHED.

Harvesting activities are proposed within the South Fork Lost Creek and Cilly Creek SMZs. These activities would follow all requirements of the SMZ Law and the Rules and would have a low risk of affecting channel stability and sediment transport through reduced recruitment of large woody material to South Fork Lost Creek, Cilly Creek, or their tributaries. A more in-depth discussion of the impacts of riparian harvesting can be found in APPENDIX E - FISHERIES ANALYSIS.

\section{- Direct and Indirect Effects of Action -Atternative E to Sediment Delivery}

Improvements to approximately 90 miles of existing road and construction of 8.2 miles of new road and 4.8 miles of temporary road would:

- reduce the estimated sediment load by approximately 18.7 tons per year;

- reduce the estimated sediment load to Cilly Creek by approximately 1.0 ton per year, and a reduce in the estimated sediment load to Soup Creek by an additional 10.1 tons of sediment beyond the reduction shown in Effects Common to Action

Alternatives $B, C, D$, and $E$, for a total reduction of approximately 33.9 tons per year.

These projected sediment reductions are net values for each watershed. These values include the projected increases in sediment delivery from new stream crossings and new road construction. A more detailed summary of sediment delivery estimates can be found in TABLE III-3 (4, 5) - ESTIMATES OF SEDIMENT DELIVERY IN SOUTH FORK LOST CREEK (CILLY CREEK, SOUP CREEK) WATERSHED.

Harvesting activities are proposed within the South Fork Lost Creek and Cilly Creek SMZs. These activities would follow all requirements of the SMZ Law and the Rules and would have a low risk of affecting channel stability and sediment transport through reduced recruitment of large woody material to South Fork Lost Creek, Cilly Creek, or their tributaries. A more in-depth discussion of the impacts of riparian harvesting can be found in APPENDIX E - FISHERIES ANALYSIS. 


\section{CUMULATIVE EFFECTS}

\section{- Cumulative Effects of. Vo-.Action. Alternative. to Sediment Delivery}

The cumulative effects would be very similar to those described in the EXISTING CONDITION portion of this analysis. Sediment loads would remain at or near present levels.

\section{- Cumulative Effects of.Action. Alternative B to Sediment Delivery}

Cumulative effects to sediment delivery would be a reduction from approximately 19.8 tons of sediment per year to approximately 0.5 tons of sediment per year in South Fork Lost Creek, reduced from 2.9 tons per year to approximately 1.9 tons per year in Cilly Creek, and reduced from 35.6 tons per year to 1.9 tons per year in soup Creek. These values include projected increases from new road and streamcrossing construction, potential increases from the replacement of stream-crossing structures, and the projected reductions in sediment delivery from upgrading surface drainage, erosion control, and BMPs on existing roads. These increases would not exceed any state waterquality laws and would follow all applicable recommendations given in the 124 and 318 permits.

\section{- Cumulative Effects of.Action .Altermative C to Sediment Delivery}

Cumulative effects to sediment delivery would be a reduction from approximately 19.8 tons of sediment per year to approximately 0.5 tons of sediment per year in the South Fork Lost Creek, reduced from 2.9 tons per year to approximately 1.9 tons per year in Cilly Creek, and reduced from 35.6 tons per year to 1.9 tons per year in Soup Creek. These values include projected increases from new road and streamcrossing construction, potential increases from the replacement of stream-crossing structures, and the projected reductions in sediment delivery from the upgrading of surface drainage, erosion control, and BMPs on existing roads. These increases would not exceed any State water-quality laws, and would follow all applicable recommendations given in the 124 and 318 permits.

\section{- Cumulative Effects of Action. Altermative D to Sediment Delivery}

Cumulative effects to sediment delivery would be a reduction from approximately 19.8 tons of sediment per year to approximately 1.1 tons of sediment per year in South Fork Lost Creek, reduced from 2.9 tons per year to approximately 2.3 tons per year in Cilly Creek, and reduced from 35.6 tons per year to 1.9 tons per year in Soup Creek. These values include projected increases from new road and streamcrossing construction, potential increases from the replacement of stream-crossing structures, and the projected reductions in sediment delivery from the upgrading of surface drainage, erosion control, and BMPs on existing roads. These increases would not exceed any State water-quality laws and would follow all applicable recommendations given in the 124 and 318 permits.

\section{- Cumulative Effects of Action. Alternative E to Sediment Delivery}

Cumulative effects to sediment delivery would be a reduction from approximately 19.8 tons of sediment per year to approximately 1.1 tons of sediment per year in South Fork Lost Creek, reduced from 2.9 tons per year to approximately 1.9 tons per year in Cilly Creek, and reduced from 35.6 tons per year to 1.7 tons per year in Soup Creek. These values include projected increases from new road and streamcrossing construction, potential increases from the replacement of stream-crossing structures, and the projected reductions in sediment 
WATERSHED AND HYDROLOGY SUMMARY

TABLE III-6 - WATER YIELD AND ECA INCREASES IN SOUTH FORK LOST CREEK WATERSHED

\begin{tabular}{|l|c|c|c|c|c|}
\hline & \multicolumn{3}{|c|}{ ALTERNATIVE } \\
\cline { 2 - 5 } & A & B & C & D & E \\
\hline $\begin{array}{l}\text { Allowable percent water-yield } \\
\text { increase }\end{array}$ & $10 \%$ & $10 \%$ & $10 \%$ & $10 \%$ & $10 \%$ \\
\hline Percent water-yield increase & 1.2 & 1.8 & 1.7 & 2.5 & 2.4 \\
\hline Acres harvested & 0 & 318 & 303 & 512 & 449 \\
\hline Miles of new road & 0 & 3.6 & 4.3 & 4.9 & 2.9 \\
\hline ECA generated & 0 & 290 & 262 & 468 & 374 \\
\hline Total ECA & 310 & 600 & 572 & 778 & 684 \\
\hline Allowable ECA & 2,626 & 2,626 & 2,626 & 2,626 & 2,626 \\
\hline
\end{tabular}

TABLE III-7 - WATER YIELD AND ECA INCREASES IN THE CILLY CREEK WATERSHED

\begin{tabular}{|l|c|c|c|c|c|}
\hline \multirow{2}{*}{} & \multicolumn{4}{|c|}{ ALTERNATIVE } \\
\cline { 2 - 6 } & A & B & C & D & E \\
\hline Allowable water-yield increase & $11 \%$ & $11 \%$ & $11 \%$ & $11 \%$ & $11 \%$ \\
\hline Percent water-yield increase & 2.3 & 9.1 & 8.7 & 11.6 & 11.9 \\
\hline Acres harvested & 0 & 896 & 883 & 986 & 1,140 \\
\hline Miles of new road & 0 & 2.3 & 2.3 & 5.3 & 3.8 \\
\hline ECA generated & 0 & 703 & 691 & 782 & 947 \\
\hline Total ECA & 348 & 1,051 & 1,039 & 1,130 & 1,295 \\
\hline Allowable ECA & 1,448 & 1,448 & 1,448 & 1,448 & 1,448 \\
\hline
\end{tabular}

TABLE III-8 - WATER YIELD AND ECA INCREASES IN THE SOUP CREEK WATERSHED

\begin{tabular}{|l|c|c|c|c|c|}
\hline \multirow{2}{*}{} & \multicolumn{4}{|c|}{ ALTERNATIVE } \\
\cline { 2 - 6 } & A & B & C & D & E \\
\hline Allowable water-yield increase & $9 \%$ & $9 \%$ & $9 \%$ & $9 \%$ & $9 \%$ \\
\hline Percent water-yield increase & 1.0 & 3.1 & 2.5 & 2.1 & 1.9 \\
\hline Acres harvested & 0 & 642 & 566 & 443 & 377 \\
\hline Miles of new road & 0 & 7.1 & 5.8 & 5.4 & 1.5 \\
\hline ECA generated & 0 & 563 & 500 & 368 & 308 \\
\hline Total ECA & 428 & 991 & 928 & 796 & 736 \\
\hline Allowable ECA & 2,202 & 2,202 & 2,202 & 2,202 & 2,202 \\
\hline
\end{tabular}

${ }^{1}$ Includes only permanent new roads 
delivery from the upgrading of surface drainage, erosion control, and BMPs on existing roads. These increases would not exceed any State water-quality laws, and would follow all applicable recommendations given in the 124 and 318 permits.

WATER YIELD

Direct and Indirect Effects

\section{- Divect and Indivect Effects of.No-.Action Altermative. A to Wouter Yield}

Water yield would not be directly or indirectly affected.

\section{- Divect and Indivect Effects of.Action -Alternative B to Water Yield}

The annual water yield would increase by an estimated 0.6 percent in the South Fork Lost Creek watershed, 6.8 percent in the Cilly Creek watershed, and 2.1 percent in the Soup Creek watershed over the current level.

\section{- Direct and Indirect Effects of.Action -Alternative C to Woter Yield}

The annual water yield would increase by an estimated 0.5 percent in the South Fork Lost Creek watershed, 6.4 percent in the Cilly Creek watershed, and 1.5 percent in the Soup Creek watershed over the current level.

\section{- Direct and Indirect Effects of Action -Alternative D to Water Yield}

The annual water yield would increase by an estimated 1.3 percent in the South Fork Lost Creek watershed, 9.3 percent in the Cilly Creek watershed, and 1.1 percent in the Soup Creek watershed over the current level.

\section{- Direct amd Imdirect Effects of.Action -Alternative E to Water Yield}

The annual water yield would increase by an estimated 1.2 percent in the South Fork Lost Creek watershed, 9.6 percent in the
Cilly Creek watershed, and 0.9 percent in the Soup Creek watershed over the current level.

\section{Cumulative Effects}

\section{- Cummative Effects of. Vo-Action .Altermative.A on Wouter Yield}

No cumulative effects on water yield would be expected.

\section{- Cumulative Effects of.Action .Alternative B on W\%ter Yield}

The removal of trees proposed in Action Alternative $B$ would increase the water yield from its current level of approximately 1.2 percent over unharvested to an estimated 1.8 percent in the South Fork Lost Creek watershed; from its current level of approximately 2.3 percent over unharvested to an estimated 9.1 percent in the Cilly Creek watershed; and from its current level of approximately 1.0 percent over unharvested to an estimated 3.1 percent in the Soup Creek watershed. This alternative leaves these watersheds well below the established threshold of concern.

A summary of the anticipated wateryield impacts of Action Alternative $B$ to the South Fork Lost Creek and Cilly Creek watersheds and Soup Creek drainage is found in TABLE III-6 (7, 8) - WATER YIELD AND ECA INCREASES IN SOUTH FORK LOST CREEK (CILLY CREEK, SOUP CREEK) WATERSHED.

\section{- Cumulative Effects of Action .Alternative Com Wrater Yield}

The removal of trees proposed in Action Alternative $\mathrm{C}$ would increase the water yield from its current level of approximately 1.2 percent over unharvested to an estimated 1.7 percent in the South Fork Lost Creek watershed; from its current level of approximately 2.3 percent over unharvested to an estimated 8.7 percent in the Cilly Creek watershed; and from its current level of approximately 1.0 percent over unharvested to an estimated 


\section{WATERSHED AND HYDROLOGY SUMMARY}

2.5 percent in the Soup Creek watershed. This alternative leaves these watersheds well below the established threshold of concern.

A summary of the anticipated wateryield impacts of Action Alternative $C$ to the South Fork Lost Creek and Cilly Creek watersheds and the Soup Creek drainage is found in TABLE III-6 (7, 8) - WATER YIELD AND ECA INCREASES IN SOUTH FORK LOST CREEK (CILLY CREEK, SOUP CREEK) WATERSHED.

\section{- Cumulative Effects of Action .Alternative D on Wrater Yield}

The removal of trees proposed in Action Alternative D would increase the water yield from its current level of approximately 1.2 percent over unharvested to an estimated 1.8 percent in the South Fork Lost Creek watershed, and from its current level of approximately 1.0 percent over unharvested to an estimated 3.1 percent in the Soup Creek watershed. This alternative leaves these watersheds well below the established threshold of concern.

The removal of trees proposed in Action Alternative $\mathrm{D}$ would increase the water yield in the Cilly Creek watershed from its current level of approximately 2.3 percent over unharvested to an estimated 11.6 percent. This alternative leaves the watershed slightly above the established threshold of concern. The estimated water-yield increases would leave a low to moderate risk of potential negative impacts in the less stable reaches and in isolated instances.

A summary of the anticipated wateryield impacts of Action Alternative D to the South Fork Lost Creek and Cilly Creek watersheds and the Soup Creek drainage is found in TABLE III-6 (7, 8) - WATER YIELD AND ECA INCREASES IN SOUTH FORK LOST CREEK (CILLY CREEK, SOUP CREEK) WATERSHED.

\section{- Cumulative Effects of Action. Alternative E on} Wrater Yield

The removal of trees proposed in Action Alternative $B$ would increase the water yield from its current level of approximately 1.2 percent over unharvested to an estimated 2.4 percent in the South Fork Lost Creek watershed, and from its current level of approximately 1.0 percent over unharvested to an estimated 1.9 percent in the soup Creek watershed. This alternative leaves these watersheds well below the established threshold of concern.

The removal of trees proposed in Action Alternative $\mathrm{E}$ would increase the water yield in the Cilly Creek watershed from its current level of approximately 2.3 percent over unharvested to an estimated 11.9 percent. This alternative leaves the watershed an estimated 0.9 percent above the established threshold of concern. The estimated water-yield increases would leave a low to moderate risk of potential negative impacts in the less stable reaches and in isolated instances.

A summary of the anticipated wateryield impacts of Action Alternative $E$ to the South Fork Lost Creek and Cilly Creek watersheds, and the Soup Creek drainage is found in TABLE III-6 (7, 8) - WATER YIELD AND ECA INCREASES IN SOUTH FORK LOST CREEK (CILLY CREEK, SOUP CREEK) WATERSHED. 
WATERSHED AND HYDROLOGY SUMMARY 


\section{OBJECTIVE}

The purpose of this abbreviated fisheries assessment is to summarize the results of the detailed fisheries analysis, which is found within the technical appendices to this EIS. The detailed fisheries analysis contains the complete EXISTING CONDITIONS, project area maps, data tables, qualitative and quantitative analyses, complete ALTERNATIVE EFFECTS, specialist recommendations, and anticipated project-level resource monitoring.

\section{INTRODUCTION}

The project area includes specific portions of the watersheds of 3 major tributaries of Swan River. From north to south, these are South Fork Lost Creek, Cilly Creek, and Soup Creek. Unnamed Creek, a tributary to soup Creek, is also included in the analysis. The Swan River drainage, including South Fork Lost, Cilly, and Soup creeks and any contributing subbasins, is

classified as B-1 in the Montana Surface Water Quality Standards (ARM 17.30 .608 (b) (i)). The B-1 classification is for multiple beneficial-use waters, including the growth and propagation of cold-water fisheries and associated aquatic life.

\section{SPECIES}

Bull trout and westslope cutthroat trout are the primary native, coldwater species addressed in this fisheries analysis. The USFWS has listed bull trout as "threatened" under the EPA. Both bull trout and westslope cutthroat trout are listed as Class-A Montana Animal Species of Concern. A Class-A designation is defined as a species or subspecies that has limited numbers and/or habitats both in Montana and elsewhere in North America, and elimination from Montana would be a significant loss to the gene pool of the species or subspecies (DFWP, MNHP, and Montana Chapter American
Fisheries Society Rankings) . DNRC has also identified bull trout and westslope cutthroat trout as sensitive species (ARM 36.11.436). The one nonnative species known to persist within the specific project area is eastern brook trout.

\section{FISHERIES-SPECIFIC ISSUES RAISED DURING SCOPING}

The issues raised both internally and through public comment during the scoping process are: proposed actions may adversely affect fisheries populations and fisheries habitat features, including flow regime, sediment, channel forms, riparian function, large woody debris, stream temperature, and connectivity, in fish-bearing streams within the project area. All of these issues will be addressed in the EXISTING CONDITIONS and ALTERNATIVE EFFECTS sections of APPENDIX E - FISHERIES ANALYSIS.

\section{STREAMS EXCLUDED FROM FISHERIES ANALYSIS}

All potential fish-bearing streams within the project area were surveyed during 2003, 2004, and 2005 for fisheries presence (see FIGURE III-5 - THREE CREEK TIMBER SALE FISH PRESENCE). Streams that were surveyed for fish presence and were determined to not contain any fish populations or provide fish habitat are considered non-fish bearing. 


\section{FIGURE III-5 - THREE CREEKS TIMBER SALE FISH PRESENCE}

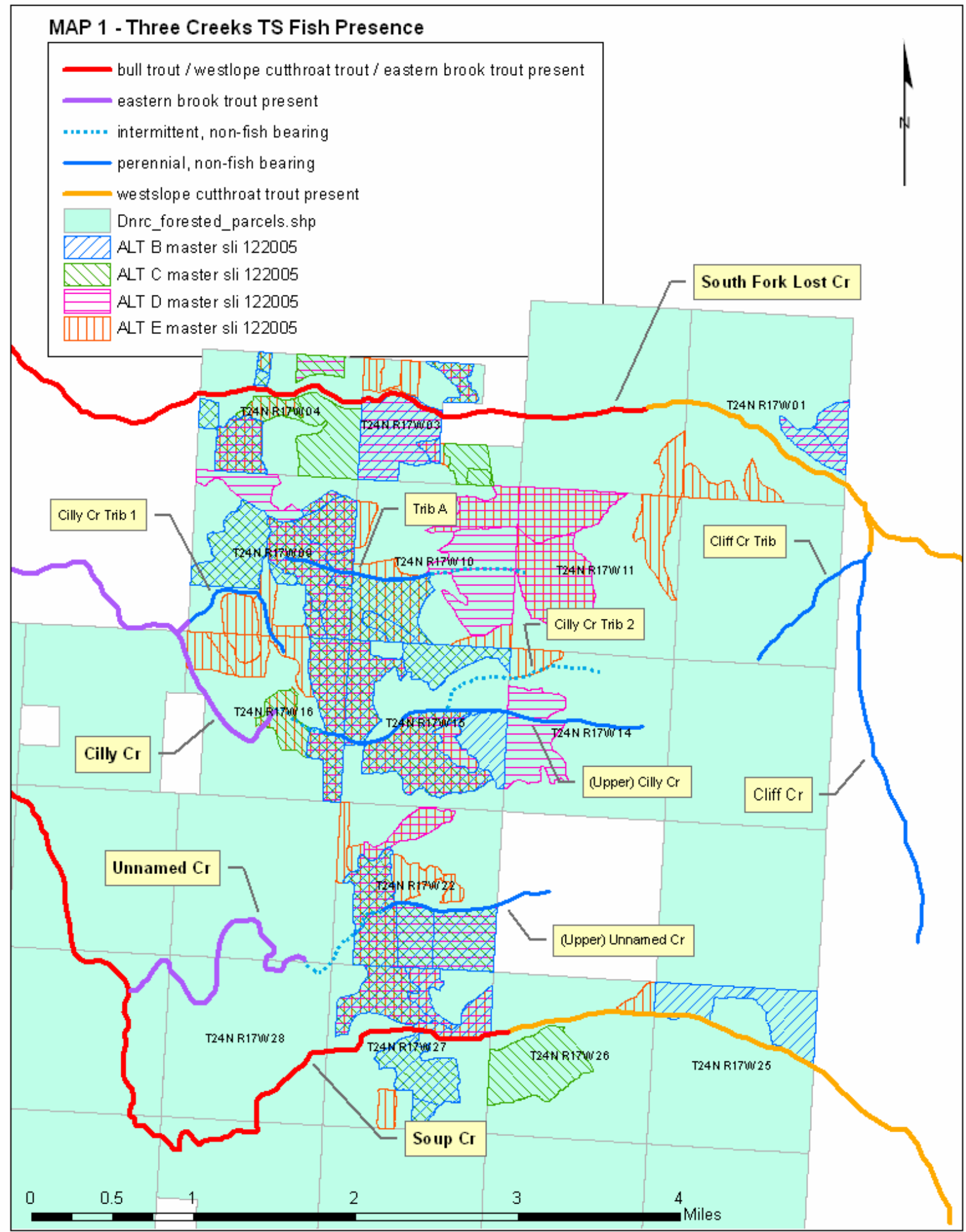




\section{ANALYSIS METHODS AND SUBISSUES}

Analysis methods are a function of the types and quality of data available for analysis, which varies among the watersheds in the project area. The analyses may either be quantitative or qualitative. The best available data for both populations and habitats will be presented separately for South Fork Lost, Cilly, Unnamed, and Soup creeks. Existing conditions and foreseeable environmental effects will be explored using the following outline of subissues:

- Populations - Presence and Genetics

- Habitat - Flow Regimes

- Habitat - Sediment

- Habitat - Channel Forms

- Habitat - Riparian Function

- Habitat - Large Woody Debris

- Habitat - Stream Temperature

- Habitat - Connectivity

- Cumulative Effects

\section{SUMMARY OF ALTERNATIVES}

See CHAPTER II - ALTERNATIVES in the THREE CREEKS TIMBER SALE PROJECT DEIS and FEIS for detailed information, specific mitigations, and road-management plans pertaining to No-Action Alternative $A$ and Action Alternatives B, C, D, and E.

\section{EXISTING CONDITIONS}

A very low impact means that the impact is unlikely to be detectable or measurable, and the impact is not likely to be detrimental to the resource. A low impact means that the impact is likely to be detectable or measurable, but the impact is not likely to be detrimental to the resource. A moderate impact means that the impact is likely to be detectable or measurable, but the impact may or may not $(50 / 50)$ be detrimental to the resource. A high impact means that the impact is likely to be detectable or measurable, and the impact is likely to be detrimental to the resource.

\section{$>$ South Fork Lost Creek}

South Fork Lost Creek is a thirdorder stream and the entire reach within the project area is considered fish bearing.

\section{- South Fork Lost Creek Populations - Presence And Genetics}

The South Fork Lost Creek watershed has been identified as a core habitat area within the Swan River drainage bull trout conservation area (Montana Bull Trout Scientific Group [MBTSG] 1996, Montana Bull Trout Restoration Team [MBTRT] 2000). Although bull trout may exhibit the resident life form in South Fork Lost Creek, this stream is used by bull trout primarily as spawning and rearing habitat for adfluvial populations associated with Swan Lake. South Fork Lost Creek supports westslope cutthroat trout exhibiting adfluvial, fluvial, and resident life forms. Existing impacts to bull trout and westslope cutthroat trout populations and genetics in South Fork Lost Creek are due primarily to the introduction of nonnative salmonids. Existing impacts to bull trout in South Fork Lost Creek include an imminent moderate to high impact due to the propagation of lake trout in the drainage and a low impact due to hybridization with eastern brook trout. Existing impacts to westslope cutthroat trout include a moderate impact due to introgression from rainbow trout hybridization and a low to moderate impact from displacement by eastern brook trout where the distributions of the 2 species overlap. 


\section{- South Fork Lost Creek Habitat - Flow Regimes}

Flow regime is the range of discharge frequencies and intensities in a specific watershed that occur throughout the year. (In this regard, flow regime is comparable to 'water yield' in APPENDIX D - HYDROLOGY AND WATERSHED ANALYSIS). The analysis of hydrologic data for South Fork Lost Creek indicates that the existing average departure in flow regime is approximately 1.2 percent above the range of naturally occurring conditions (see APPENDIX D HYDROLOGY AND WATERSHED

ANALYSIS). Changes in flow regime have been known to affect bull trout and westslope cutthroat trout spawning migration, habitat available for spawning, and embryo survival. Although, in general, the existing levels of increased flow regime described for the project area are not likely to have adverse effects to fisheries spawning and embryo survival. The potential is very low for very low existing direct and indirect impacts to native and nonnative fish species as a result of flow-regime modifications to South Fork Lost Creek within the project area.

\section{- South Fork Lost Creek Habitat - Sediment}

The existing stream sediment processes of South Fork Lost Creek are described using Rosgen stream morphological type, several different sedimentcomposition surveys, and streambank stability. MCNeil core data indicates that the substrates of known spawning reaches are not "threatened", substrate scores describing streambed substrate embeddedness also indicate that known bull trout rearing habitat is not "threatened", and Wolman pebble counts suggest that high levels of streambed substrates are in the gravel, cobble, and boulder classes. Additionally, a recent streambank-stability assessment shows very low levels of potential streambank erosion, a natural source of sedimentation. Based on these observations, no existing direct and indirect impacts to the sediment component of bull trout and westslope cutthroat trout habitat are likely in South Fork Lost Creek.

\section{- South Fork Lost Creek Habitat - Channel Forms}

Considering stream-reach gradients, valley location, and geomorphological processes, the observed proportions of habitat types for each reach are within the broad ranges of expected conditions. No existing direct or indirect impacts to the channel-form component of bull trout and westslope cutthroat trout habitat are apparent in South Fork Lost Creek.

\section{- South Fork Lost Creek Habitat -} Riparian Function

The stream riparian area is broadly defined as the interface or linkage between the terrestrial and aquatic zones, and this area is critical for regulating the recruitment of large woody debris, the interception of solar radiation, stream-nutrient inputs, and other variables (Hansen et al 1995). The predominant riparian stand type along South Fork Lost Creek within the project area is Western Red Cedar/Oak Fern. Surveys indicate that the quadratic mean diameter of riparian trees is 9.1 inches, the average number of trees per acre is 764, and the average basal area per acre is 346.0 square feet. The site potential tree height along riparian zones 
adjacent to the proposed harvest units is approximately 95 feet. Field measurements indicate that the existing riparian tree vegetation blocks an average of 65 percent of direct solar radiation during July and an average of 81 percent of direct solar radiation during August. Due to the location of the Forest Service Road 680 corridor, the existing direct or indirect impacts to the riparian-function component of bull trout and westslope cutthroat trout habitat are low in South Fork Lost Creek.

\section{- South Fork Lost Creek Habitat - Large Woody Debris}

Large woody debris is recruited to the stream channel from adjacent and upstream riparian vegetation; the material is a critical component in the formation of complex habitat for bull trout and westslope cutthroat trout. Survey data suggests that the existing frequencies of large woody debris in South Fork Lost Creek are within the expected range of frequencies when compared to reference reaches in the region with similar morphological characteristics. No existing direct or indirect impacts to the large-woody-debris component of bull trout and westslope cutthroat trout habitat are apparent in South Fork Lost Creek.

\section{- South Fork Lost Creek Habitat - Stream Temperature}

Stream-temperature data for South Fork Lost Creek is available for 2001, 2003, 2004, and 2005. In respect to bull trout, the recorded temperature ranges are within the species' tolerances as observed in various studies. No existing direct or indirect

impacts to the stream-temperature component of bull trout and westslope cutthroat trout habitat are apparent in South Fork Lost Creek.

\section{- South Fork Lost Creek Habitat -} Connectivity

Two bridge crossings exist on South Fork Lost Creek in the project area and provide full passage of all life stages of bull trout and westslope cutthroat trout. Although waterfall barriers limit bull trout and westslope cutthroat trout migration in South Fork Lost Creek, these stream features are naturally occurring and not considered an existing impact. No direct or indirect impacts to the connectivity component of bull trout and westslope cutthroat trout habitat exist in South Fork Lost Creek.

\section{- South Fork Lost Creek - Existing Collective Past and Present Impacts}

Existing collective past and present impacts to fisheries in the Three Creeks Timber Sale Project area are determined by assessing the collective existing direct and indirect impacts and other related existing actions affecting the fish-bearing streams in the project area. Determinations of existing collective impacts are primarily a consequence of the overwhelming impact to native fish species from nonnative fish species in conjunction with existing impacts to other habitat variables. As a result of these considerations, a moderate collective impact to bull trout and westslope cutthroat trout likely exists in South Fork Lost Creek.

\section{Cilly Creek}

Cilly Creek is a second-order stream, and only a very short reach within the project area is fish bearing. 
- Cilly Creek Populations Presence and Genetics

Eastern brook trout are the only fish inhabiting Cilly Creek within and adjacent to the project area. As eastern brook trout currently thrive in Cilly Creek, a reasonable presumption is that bull trout and westslope cutthroat trout historically occupied the stream to some unknown degree. The complete displacement by eastern brook trout, therefore, constitutes a high existing impact to bull trout and westslope cutthroat trout populations and genetics in Cilly Creek.

- Cilly Creek Habitat - Flow Regimes

The analysis of hydrologic data for Cilly Creek indicates that the existing average departure in flow regime is approximately 2.3 percent above the range of naturally occurring conditions (see APPENDIX D - HYDROLOGY AND WATERSHED ANALYSIS). In general, the existing levels of increased flow regime described for the project area are not likely to have adverse effects to fisheries spawning and embryo survival. The potential is very low for low existing direct and indirect impacts to native and nonnative fish species as a result of flowregime modifications to Cilly Creek within the project area.

\section{- Cilly Creek Habitat - Sediment}

The existing sediment characteristics of Cilly Creek are likely representative of historic trends. Field surveys of the stream during 2004 and 2005 did not reveal channel or riparian disturbances that would otherwise point toward a deviation in the expected characteristics of sediment. No direct and indirect impacts to the sediment component of fish habitat in Cilly Creek are likely.

- Cilly Creek Habitat - Channel Forms

The stream formations of the reach are broadly described as exhibiting the 'forced poolriffle' and 'pool-riffle' Montgomery/Buffington classification. No direct or indirect impacts to the channelform component of fish habitat in Cilly Creek are apparent.

- Cilly Creek Habitat - Riparian Function

The site potential tree height calculated by DNRC personnel during 2004 is 91 feet. Field measurements indicate that the existing riparian tree vegetation blocks an average of 76 percent of direct solar radiation during July and an average of 83 percent of direct solar radiation during August. Past disturbance in the riparian areas of Cilly Creek include the random, selective harvest of large trees until approximately 30 years ago. Since the result of the past associated action poses an existing low risk of reduced recruitable large woody debris over the foreseeable near future, potential low impacts exist.

- Cilly Creek Habitat - Large Woody Debris

The frequency of existing large woody debris in the fish-bearing reach of Cilly Creek is likely consistent with the range of frequencies observed in other similar channels on nearby South Fork Lost Creek and Soup Creek and described within this analysis. No direct or indirect impacts to the large-woody-debris component of fish habitat in Cilly Creek likely exist. 
- Cilly Creek Habitat - Stream Temperature

Stream-temperature data for Cilly Creek is available for 2004 and 2005. No direct or indirect impacts to the stream-temperature component of fish habitat are apparent in Cilly Creek.

\section{- Cilly Habitat - Connectivity}

One bridge crossing currently exists on Cilly Creek within the project area and provides full passage of all life stages of eastern brook trout (and bull trout and westslope cutthroat trout if those species were present.) Three culvert crossings also exist on Cilly Creek in the project area. The 3 culvert crossings represent existing low direct and indirect impacts to the connectivity component of fish habitat in Cilly Creek.

- Cilly Creek - Existing Collective Past and Present Impacts

Determinations of existing collective impacts are primarily a consequence of the overwhelming impact to native fish species from nonnative fish species in conjunction with existing impacts to other habitat variables. As a result of these considerations, a high existing collective impact to bull trout and westslope cutthroat trout is likely in Cilly Creek.

\section{$>$ Unnamed Creek}

Unnamed Creek is a second-order stream, and the fish-bearing reach is downstream of the project area.

\section{- Unnamed Creek Populations - Presence And Genetics}

Eastern brook trout have been determined to be the only fish inhabiting Unnamed Creek downstream from the project area. Primarily due to high seasonal stream temperatures, neither bull trout nor westslope cutthroat trout have likely utilized Unnamed Creek as habitat for any period of time. No existing direct and indirect impacts to bull trout and westslope cutthroat trout presence and genetics exist in Unnamed Creek.

\section{- Unnamed Creek Habitat - Flow Regimes}

The analysis of hydrologic data for Unnamed Creek indicates that the existing average departure in flow regime is approximately 0.5 percent above the range of naturally occurring conditions. In general, the existing levels of increased flow regime described for the project area are not likely to have adverse effects to fisheries' spawning and embryo survival. The potential is very low for very low existing direct and indirect impacts to nonnative fish species as a result of flow-regime modifications to Unnamed Creek downstream of the project area.

\section{- Unnamed Creek Habitat - Sediment}

The stream morphology of the fish-bearing reach of Unnamed Creek downstream of the project area is described using Rosgen river classification (Rosgen 1996). Field surveys of the stream during 2005 did not reveal channel or riparian disturbances that would otherwise point toward a deviation in the expected characteristics of sediment. No direct and indirect impacts to the sediment component of fish habitat likely exist in Unnamed Creek.

\section{- Unnamed Creek Habitat - Channel Forms}

In those reaches of the stream that flow through forested areas, the stream formations are broadly described as exhibiting the 'forced pool-riffle' and 'poolriffle' classification. In those 
reaches of the stream that flow through various sedge meadow complexes, the stream formations are broadly described as exhibiting the 'plane bed' classification. No direct or indirect impacts to the channel form component of fish habitat are apparent in Unnamed Creek.

\section{- Unnamed Creek Habitat - Riparian Function}

The proposed forest-management activities associated with each alternative are not expected to occur adjacent to the fishbearing reach of Unnamed Creek. For this reason, a description of the existing condition of site potential tree height is not needed for the fisheries analysis. Field surveys of the stream during 2005 did not reveal extraordinary riparian disturbances that would otherwise point toward a deviation in the expected range of stream shade conditions. However, past disturbance in the riparian areas of Unnamed Creek may include the random, selective harvesting of large trees until approximately 30 years ago. A potential low impact exists since the result of the past associated action poses a low risk of reduced recruitable large woody debris over the foreseeable near future.

\section{- Unnamed Creek Habitat - Large Woody Debris}

The frequency of existing large woody debris in the fish-bearing reach of Unnamed Creek is likely consistent with the range of frequencies observed in other similar channels on nearby South Fork Lost Creek and Soup Creek. In those reaches of the stream that flow through various sedge meadow complexes, field surveys did not reveal that large woody debris plays an important role in stream function. No direct or indirect impacts to the large- woody-debris component of fish habitat likely exist in Unnamed Creek.

\section{- Unnamed Creek Habitat - Stream Temperature}

Instantaneous daytime stream temperatures were recorded at 3 locations of the fish-bearing reach of Unnamed Creek during 2005. Although these temperatures are relatively high, the field surveys of the stream during 2005 did not reveal extraordinary riparian disturbances or stream conditions that would otherwise point toward a deviation in the observed range of stream temperature. No apparent direct or indirect impacts to the stream-temperature component of fish habitat exist in Unnamed Creek.

\section{- Unnamed Creek Habitat - Connectivity}

Unnamed Creek has 2 culvert crossings adjacent to the project area. One crossing poses a migration barrier to eastern brook trout except for a portion of the strongest swimming adults. The other poses a complete migration barrier to all life stages of eastern brook trout. These 2 crossings represent existing moderate to high direct and indirect impacts to the connectivity component of fish habitat in Unnamed Creek.

\section{- Unnamed Creek - Existing Collective Past and Present Impacts}

Existing collective impacts to fisheries are likely moderate in Unnamed Creek.

\section{Soup Creek}

Soup Creek is a third-order stream and the entire reach within the project area is fish bearing. 


\section{- Soup Creek Populations - Presence and Genetics}

The Soup Creek watershed has been identified as a core habitat area within the Swan River drainage bull trout conservation area (MBTSG 1996, MBTRT 2000). Although bull trout may exhibit the resident life form in soup Creek, this stream is used by bull trout primarily as spawning and rearing habitat for adfluvial populations associated with Swan Lake. Soup Creek supports westslope cutthroat trout exhibiting adfluvial, fluvial, and resident life forms. Existing impacts to bull trout and westslope cutthroat trout populations and genetics in soup Creek are due primarily to the introduction of nonnative salmonids. Existing impacts to bull trout in soup Creek include an imminent moderate to high impact due to the propagation of lake trout in the drainage and a low impact due to hybridization with eastern brook trout. Existing impacts to westslope cutthroat trout include a likely moderate impact due to

introgression from rainbow trout hybridization and a moderate impact from displacement by eastern brook trout where the 2 species' distributions overlap.

\section{- Soup Creek Habitat - Flow Regimes}

The analysis of hydrologic data for Soup Creek indicates that the existing average departure in flow regime is approximately 1.0 percent above the range of naturally occurring conditions (see APPENDIX D - HYDROLOGY AND WATERSHED ANALYSIS). In general, the existing levels of increased flow regime described for the project area are not likely to have adverse effects to fisheries spawning and embryo survival. The potential is very low for very low existing direct and indirect impacts to native and nonnative fish species as a result of flow-regime modifications to Soup Creek within the project area.

\section{- Soup Creek Habitat - Sediment}

Existing stream sediment processes that are described in this FISHERIES ANALYSIS are Rosgen stream morphological type, sediment budget, and streambank stability. The most recent MCNeil core data (1998 through 2004) indicates that the substrates of known spawning reaches are "threatened", and the substrate scores from 2004 and 2005 describing streambed substrate embeddedness also indicate that known bull trout rearing habitat is "threatened". Wolman pebble counts also suggest that high levels of fine (less than 8 millimeters) streambed surface substrates are in the reach immediately downstream of the project area. On the contrary, a recent streambankstability assessment in the same reach shows very low levels of potential streambank erosion, a natural source of sedimentation. Reasons for the measured levels of fine substrates may include activities related to land management, natural cycles in sediment transport processes, drought-related low seasonal flows, or a combination of 2 or more of these and other factors. As 3 historic, native material bridges are in the process of failing within the upper reaches of Soup Creek, related activities cannot be conclusively ruled out as a potential source of a portion of fine substrates found in the reach immediately downstream of the project area. In general, however, measurements of substrate within the upper reaches are within the expected ranges of conditions for the respective morphological stream 
type. Based on these

observations, direct and indirect impacts to the sediment component of bull trout and westslope cutthroat trout habitat in soup Creek are likely low to moderate.

\section{- Soup Creek Habitat - Channel Forms}

Considering reach gradients, valley location, and geomorphological processes, the observed proportions of habitat types for each reach are within the broad ranges of expected conditions. No direct or indirect impacts to the channelform component of bull trout and westslope cutthroat trout habitat are apparent in Soup Creek.

\section{- Soup Creek Habitat - Riparian Function}

The predominant riparian stand types along soup Creek within the project area include various grand fir and Engelmann spruce series. Results of the "Lower Soup Riparian Cruise" surveys indicate that the quadratic mean diameter of riparian trees is 5.9 inches, the average number of trees per acre is 1,032, and the average basal area per acre is 195.9 square feet. Results of the "Upper Soup Riparian Cruise" surveys indicate that the quadratic mean diameter of riparian trees is 8.5 inches, the average number of trees per acre is 262, and the average basal area per acre is 104.2 square feet. Based on data reflecting relatively low quadratic mean diameters and basal areas from the 2 separate surveys, the frequency of large trees in the riparian areas of Soup Creek within the project area is likely relatively low. The site potential tree height calculated during the "Lower Soup Riparian Cruise" surveys is approximately 83 feet, and the site potential tree height calculated during the
"Upper Soup Riparian Cruise" surveys is approximately 74 feet. Measurements indicate that the existing riparian tree vegetation blocks an average of 63 percent of direct solar radiation during July and an average of 75 percent of direct solar radiation during August. Past disturbance in the riparian areas of Soup Creek include the random, selective harvesting of large trees until approximately 30 years ago. Based on the relatively low frequency of large trees in the "Lower Soup Riparian Cruise" and "Upper Soup Riparian Cruise" data sets, this level of past random, selective riparian harvesting likely represents a potential low existing impact to native fisheries in soup Creek. The potential impact is low since the result of the past associated action poses an existing low risk of reduced recruitable large woody debris over the foreseeable near future.

\section{- Soup Creek Habitat - Large Woody Debris}

Survey data suggests that the existing frequency of large woody debris in all reaches of soup Creek are within the expected range of frequencies when compared to reference reaches in the region with similar morphological characteristics. No apparent direct or indirect impacts to the large-woody-debris component of bull trout and westslope cutthroat trout habitat exist in soup Creek.

\section{- Soup Creek Habitat - Stream Temperature}

Stream-temperature data for soup Creek is available for 2001, 2003, 2004 and 2005. In respect to bull trout, some of the recorded temperature ranges are not within the species' tolerances as observed in various studies. An increase in seasonal 
maximum stream temperature during 2003 and 2004 represents a potential low existing direct and indirect impact to the streamtemperature component of bull trout and westslope cutthroat trout habitat in the reach of Soup Creek immediately downstream of the project area. No apparent direct or indirect impacts to the stream-temperature component of bull trout and westslope cutthroat trout habitat exist in the upper reaches of Soup Creek.

- Soup Creek Habitat - Connectivity

Soup Creek currently has 5 bridge crossings within and immediately adjacent to the project area. All 5 crossings provide full passage of all life stages of bull trout and westslope cutthroat trout. Several sets of naturally occurring cascades and small waterfalls that pose complete migration barriers to bull trout occur on soup Creek. Both bull trout and westslope cutthroat trout exist below the barriers, and only westslope cutthroat trout are known to exist upstream of the barriers. Although the waterfall migration barriers limit bull trout and westslope cutthroat trout migration in Soup Creek, the stream features are naturally occurring and not considered an existing impact. No direct or indirect impacts to the connectivity component of bull trout and westslope cutthroat trout habitat exist in soup Creek.

- Soup Creek - Existing Collective Past and Present Impacts

Determinations of existing collective impacts are primarily a consequence of the overwhelming impact to native fish species from nonnative fish species in conjunction with existing impacts to other habitat variables. As a result of these considerations, existing collective impacts to bull trout and westslope cutthroat trout are likely moderate in Soup Creek.

\section{ALTERNATIVE EFFECTS}

\section{DIRECT AND INDIRECT EFFECTS FOR SOUTH FORK LOST, CILLY, UNNAMED, AND SOUP CREEKS}

The purpose of this fisheries analysis is the assessment of potential impacts to cold-water fisheries within the Three Creeks Timber sale Project area as a result of implementing any of the project alternatives. The following subsections summarize the risk of a particular impact occurring. The assessment of environmental effects in this fisheries analysis is based, in part, on the assumption that the Specialist Recommendations (located at end of APPENDIX E - FISHERIES ANALYSIS) will be implemented through contract specifications and monitoring.

\section{Populations - Presence and Genetics}

\section{- Direct and Indirect Effects of . Vo-Action -Atternative. A on Populations-Presence and Genetics}

No direct or indirect impacts would occur to bull trout, westslope cutthroat trout, or other fisheries population presence or genetics in South Fork Lost, Cilly, Unnamed, or Soup creeks beyond those described under EXISTING CONDITIONS.

\section{- Direct and Indirect Effects of.Action -Alternatives B, C, D, and E on Populations - Presence and Genetics}

None of the actions associated with any of the action alternatives involve the direct or indirect manipulation of species population presence or genetics in the project area. As a result of the selection of an action alternative, no impacts to bull trout, westslope cutthroat trout, or other fisheries population presence or genetics in South Fork Lost, Cilly, Unnamed, or 
Soup creeks are expected beyond those described in the EXISTING CONDITIONS.

\section{Habitat - Flow Regimes}

\section{- Divect amd Indivect Effects of . Vo-.Action -Alternative A on Habitat - Flow Regimes}

No direct or indirect impacts to the bull trout, westslope cutthroat trout, or other fisheries-habitat component of flow regime in south Fork Lost Creek, Cilly Creek, Unnamed Creek, or Soup Creek would occur beyond those described under EXISTING CONDITIONS.

\section{- Direct and Indirect Effects of Action -Alternative B, C, and D on Habitat - Flow Regimes}

Changes in flow regime can affect native and nonnative fish-spawning migration, spawning behavior, potential spawning habitat, and embryo survival. These effects typically occur through modifications of stream morphology, sediment budget, streambank stability, stream-temperature ranges, and channel formations. With respect to the existing conditions described at the beginning of this analysis, potential modifications of flow regimes as a result of the selection of Action Alternatives B, $C$, and $D$ (see APPENDIX D HYDROLOGY AND WATERSHED ANALYSIS) are expected to have a very low risk of very low impacts to the fisheries habitat variable of flow regime in South Fork Lost Creek and Soup Creek. A low risk of low impacts to the fisheries habitat variable of flow regime is expected in Cilly Creek and Unnamed Creek.

\section{- Direct and Indirect Effects of Action -Alternative E on Habitat - Flow Regimes}

With respect to the existing conditions described at the beginning of this analysis, potential modifications of flow regimes as a result of the selection of Action Alternative E (see APPENDIX D - HYDROLOGY AND WATERSHED ANALYSIS) are expected to have a very low risk of very low impacts to the fisheries habitat variable of flow regime in south Fork Lost, Unnamed, and Soup creeks. A low risk of low impacts to the fisheries habitat variable of flow regime is expected in Cilly Creek.

\section{Habitat - Sediment}

\section{- Direct and Indivect Effects of.No-Action -Atternative.A on Habitat-Sediment}

No direct or indirect impacts to the bull trout, westslope cutthroat trout, or other fisheries habitat component of sediment in South Fork Lost, Cilly, Unnamed, or Soup creeks would occur beyond those described under EXISTING CONDITIONS.

\section{- Direct and Indirect Effects of.Action Atternatives B and C on Habitat-Sediment}

Modifications of stream sediment size classes, especially with trends toward fine size classes, could adversely affect bull trout, westslope cutthroat trout, or other fisheries in the project area by reducing the quality of spawning habitat, in-stream cover, rearing habitat, and wintering habitat. Increased levels of fine sediments can be introduced to the stream system from various sources, including bank erosion due to stream channel instability, road features, root wads of wind-thrown trees adjacent to the stream channel, and adjacent timberharvesting operations. Data from APPENDIX D - HYDROLOGY AND WATERSHED ANALYSIS indicates that the range of potential water-yield increases as a result of Action Alternatives $\mathrm{B}$ and $\mathrm{C}$ are generally insufficient to facilitate the development of unstable stream channels. That analysis also indicates that road-stream crossing removals associated with Action Alternatives $\mathrm{B}$ and $\mathrm{C}$ would reduce 
sedimentation to South Fork Lost Creek by approximately 19.3 tons per year, Cilly Creek by approximately 1.0 tons per year, and Soup Creek by approximately 33.7 tons per year. New roadstream crossings installed as part of Action Alternatives $B$ and $C$ may lead to a disproportionate increase in the quantities of fine-sediment size classes in fish-bearing streams and non-fish-bearingconnected tributaries. Sediment inputs from the wind-thrown root wads of adjacent trees occur throughout unmanaged stream channels; however, in some cases, this process may be exacerbated by increased levels of wind-thrown trees as a result of riparian timber-harvesting actions. Harvesting activities within the riparian area may disturb soils, which can lead to erosion and increased levels of sedimentation to streams. As a result of the selection of Action Alternatives B and $\mathrm{C}$, a low risk of low impacts to the bull trout, westslope cutthroat trout, or other fisheries habitat component of sediment is expected in South Fork Lost, Cilly, and Soup creeks. A moderate risk of moderate impacts is expected in Unnamed Creek.

\section{- Direct and Indirect Effects of. Action -Atternative D on Habitat - Sediment}

APPENDIX D - HYDROLOGY AND WATERSHED ANALYSIS also indicates that removals of road-stream crossings associated with Action Alternative D would reduce sedimentation to South Fork Lost Creek by approximately 18.7 tons per year, Cilly Creek by approximately 0.6 tons per year, and Soup Creek by approximately 33.6 tons per year. Additionally, new road-stream crossings and potential impacts from riparian timber-harvesting actions, which are specific to Action Alternative D, may also lead to erosion and increased sedimentation to streams in the project area. As a result of the selection of Action Alternatives D, a low risk of low impacts to the bull trout, westslope cutthroat trout, or other fisheries habitat component of sediment is expected in South Fork Lost and Soup creeks. A moderate risk of moderate impacts is expected in Cilly and Unnamed creeks.

\section{- Direct and Indirect Effects of.Action -Atternative E on Habitat-Sediment}

APPENDIX D - HYDROLOGY AND WATERSHED ANALYSIS also indicates that removals of road-stream crossings associated with Action Alternative $\mathrm{E}$ would reduce sedimentation to South Fork Lost Creek by approximately 18.7 tons per year, Cilly Creek by approximately 0.6 tons per year, and Soup Creek by approximately 33.9 tons per year. Additionally, new road-stream crossings and potential impacts from riparian timber-harvesting actions, which are specific to Action Alternative E, may also lead to erosion and increased sedimentation to streams in the project area. As a result of the selection of Action Alternatives $E$, a low risk of low impacts to the bull trout, westslope cutthroat trout, or other fisheries habitat component of sediment is expected in South Fork Lost, Cilly, Unnamed, and Soup creeks.

\section{Habitat - Channel Forms}

\section{- Divect and Imdivect Effects of . Vo-Action -Alternative A on Habitat-Chammel Forms}

No direct or indirect impacts to the bull trout, westslope cutthroat trout, or other fisheries habitat component of channel forms in South Fork Lost Creek, Cilly Creek, Unnamed Creek, or Soup Creek would occur beyond those described under EXISTING CONDITIONS. 


\section{- Direct amd Indirect Effects of Action -Alternatives B and Con Habitat-Chammel Forms}

Potential changes to stream channel forms are primarily a function of modifications to flow regimes and consequent relationships with existing sediment size classes (Montgomery and Buffington 1997). A shift in channel forms may lead to a reduction in the quantity of rearing and wintering habitat available to bull trout, westslope cutthroat trout, and other fisheries. As indicated in the risk assessment for flow regime, a very low risk of very low impacts is expected in South Fork Lost and Soup creeks, and a low risk of low impacts is expected in Cilly and Unnamed creeks. As indicated in the risk assessment for sediment, a low risk of low impacts to

fisheries is expected in South Fork Lost, Cilly, and Soup creeks, and a moderate risk of moderate impacts is expected in Unnamed Creek. A proportional or overall low risk of low direct and indirect impacts to channel forms in South Fork Lost, Cilly, and Soup creeks is also expected. A moderate risk of low impacts to channel forms is expected in Unnamed Creek.

\section{- Direct and Indirect Effects of Action -Atternatives D on Habitat - Channel Forms}

As indicated in the risk assessment for flow regime, a very low risk of very low impacts is expected in South Fork Lost Creek and Soup Creek, and a low risk of low impacts is expected in Cilly Creek and Unnamed Creek. As indicated in the risk assessment for sediment, a low risk of low impacts to fisheries is expected in south Fork Lost and Soup creeks, and a moderate risk of moderate impacts is expected in Cilly and Unnamed creeks. A proportional or overall low risk of low direct and indirect impacts to channel forms in South Fork Lost and Soup creeks is also expected. A moderate risk of low impacts to channel forms is expected in Cilly and Unnamed creeks.

\section{- Direct and Indirect Effects of Action -Alternatives E on Habitat - Chamnel Forms}

As indicated in the risk assessment for flow regime, a very low risk of very low impacts is expected in South Fork Lost, Unnamed and Soup creeks, and a low risk of low impacts is expected in Cilly Creek. As indicated in the risk assessment for sediment, a low risk of low impacts to fisheries is expected in South Fork Lost, Cilly, Unnamed, and Soup creeks. A proportional or overall low risk of low direct and indirect impacts to channel forms in South Fork Lost, Cilly, and Soup creeks is also expected. A moderate risk of low impacts to channel forms is expected in Unnamed Creek.

Habitat - Riparian Function

\section{- Direct and Indirect Effects of .No-Action -Atternative A on Habitat-Ripariam Fumction}

No direct or indirect impacts to the bull trout, westslope cutthroat trout, or other fisheries habitat component of riparian function in South Fork Lost, Cilly, Unnamed, or Soup creeks would occur beyond those described under EXISTING CONDITIONS.

\section{- Direct and Imdirect Effects of.Action -Alternative B on Habitat-Riparian Fumction}

The selective riparian harvest associated with this proposed action could affect riparian function. The specific variables of riparian function that may be affected are the compositions of stand types, the quantity of recruitable large woody debris within the site potential tree height, and stream shading. After an assessment of the potential effects in South Fork Lost Creek, which includes (1) an affected area equal to approximately 3 percent of 
the total riparian area adjacent to bull trout or westslope cutthroat trout habitat, (2) no foreseeable adverse effects to stand type, (3) a relatively minor reduction in potentially recruitable large woody debris, and (4) an estimated maximum reduction in stream shading of 20 percent, an overall moderate risk of low impacts to the riparian function component of fish habitat is expected in that stream. Moderate reductions in stream shading would have a moderate risk of low impacts to stream temperatures within the downstream fish-bearing reaches of Cilly and Unnamed creeks. After an assessment of potential effects in Soup Creek, which includes (1) an affected area equal to approximately 6 percent of the total riparian area adjacent to bull trout or westslope cutthroat trout habitat, (2) no foreseeable adverse effects to stand type, (3) a relatively minor reduction in potentially recruitable large woody debris, and (4) an estimated maximum reduction in stream shading of 5 percent, an overall moderate risk of low impacts to the riparian-function component of fish habitat in Soup Creek is expected.

\section{- Direct and Indirect Effects of. Action} Alternative C on Habitat - Riparian Function

A potential very low risk of very low impacts to the riparian function component of fish habitat would occur in South Fork Lost Creek as a result of selecting this action alternative. After an assessment of the potential effects in Cilly Creek, which includes (1) an affected area equal to approximately 3 percent of the total riparian area adjacent to eastern brook trout habitat, (2) a potential moderate reduction in recruitable large woody debris to the fish-bearing reach, (3) a potential moderate reduction in stream shading to the fish-bearing reach, and (4) a potential moderate reduction in stream shading to the non-fish-bearing reach, an overall moderate risk of low impacts to the riparian function component of fish habitat is expected in that stream. An overall moderate risk of low impacts to the riparian-function component of fish habitat is expected in Unnamed Creek. After an assessment of potential effects in Soup Creek, which includes (1) an affected area equal to approximately one-tenth of 1 percent of the total riparian area adjacent to bull trout or westslope cutthroat trout habitat, (2) no foreseeable adverse effects to stand type, (3) a relatively very minor reduction in potentially recruitable large woody debris, and (4) an estimated very minor reduction in stream shading, an overall very low risk of very low impacts to the riparian-function component of fish habitat is expected in Soup Creek.

\section{- Direct and Indirect Effects of Action -Atternative D on Habitat-Ripariam Fumction}

Impacts to the riparian-function component of fish habitat in South Fork Lost Creek are expected to be the same as those described in the detailed analysis of riparian function in Action Alternative B. Moderate reductions in stream shading would have a moderate risk of low impacts to stream temperatures within the downstream fish-bearing reaches of Cilly and Unnamed creeks. The anticipated effects of the selective riparian harvest adjacent to soup Creek are expected to be the same as the results of the detailed analysis in Action Alternative $B$ for the 'Lower' Soup area. The results of that detailed analysis indicate an expected overall moderate risk of low impacts to the riparianfunction component of fish habitat in Soup Creek. 


\section{- Direct amd Indirect Effects of Action} -Atternative E on Habitat - Ripariam Fumction

A potential very low risk of very low impacts to the riparianfunction component of fish habitat would occur in South Fork Lost Creek as a result of selecting this action alternative. After an assessment of the potential effects in Cilly Creek, which includes (1) an affected area equal to approximately 7 percent of the total riparian area adjacent to eastern brook trout habitat, (2) a potential moderate reduction in recruitable large woody debris to the fish-bearing reach, (3) a potential moderate reduction in stream shading to the fish-bearing reach, and (4) a potential moderate reduction in stream shading to the non-fish-bearing reach, an overall moderate risk of low impacts to the riparian function component of fish habitat is expected in Cilly Creek. Minor reductions in stream shading would have a moderate risk of low impacts to stream temperatures within the downstream fish-bearing reaches of Unnamed Creek. The anticipated effects of the selective riparian harvesting adjacent to Soup Creek are expected to be the same as the results of the detailed analysis in Action Alternative B for the 'Lower' Soup area. The results of that detailed analysis indicate an expected overall moderate risk of low impacts to the riparian-function component of fish habitat in soup Creek.

Habitat - Large Woody Debris

\section{- Direct and Indirect Effects of. No--Action} -Alternative $A$ on Habitat - Large Woody Debris

No direct or indirect impacts to the bull trout, westslope cutthroat trout, or other fisheries habitat component of large woody debris in South Fork Lost, Cilly, Unnamed, or Soup creeks would occur beyond those described under Existing Conditions.

\section{- Direct and Indirect Effects of Action -Alternative B on Habitat - Large Woody Debris}

Selective riparian harvesting is the proposed action associated with the action alternatives that may affect in-stream large woody debris. Selective riparian harvesting may affect in-stream large woody debris by modifying the amounts of potentially recruitable large woody debris and modifying existing patterns of windthrow and windsnap. A specific variable of large woody debris that may be affected by the selective riparian harvesting is the frequency of instream large woody debris. A low risk of very low impacts to the habitat component of large woody debris are expected in South Fork Lost and Soup creeks as a result of implementing Action Alternative B. No impacts to the habitat component of large woody debris are expected in Cilly and Unnamed creeks.

\section{- Direct and Imdirect Effects of Action -Altermative C on Habitat - Large Woody Debris}

A low risk of low impacts to the habitat component of large woody debris is expected in Cilly Creek as a result of implementing Action Alternative $\mathrm{C}$, and a very low risk of very low direct and indirect impacts is expected in soup Creek. No impacts are expected in South Fork Lost and Unnamed creeks.

\section{- Direct and Indirect Effects of.Action Altermative D on Habitat - Large Woody Debris}

A low risk of very low impacts to the habitat component of large woody debris are expected in south Fork Lost and Soup creeks as a result of implementing Action Alternative D. No impacts are expected in Cilly and Unnamed creeks. 


\section{- Direct and Indirect Effects of. Action .Alternative E on Habitat - Large Woody Debris}

A moderate risk of low impacts to the habitat component of large woody debris is expected in Cilly Creek as a result of implementing Action Alternative $E$, and a low risk of very low direct and indirect impacts is expected in Soup Creek; no impacts are expected in South Fork Lost and Unnamed creeks.

Habitat - Stream Temperature

\section{- Direct and Indivect Effects of .No-Action -Atternative.A on Habitat-Stream Temperuture}

No direct or indirect impacts would occur to the bull trout, westslope cutthroat trout, or other fisheries habitat components of stream temperature in South Fork Lost, Cilly, Unnamed, or Soup creeks beyond those described under EXISTING CONDITIONS.

\section{- Direct and Indirect Effects of. Action -Alternative B on Habitat - Stream Temperature}

Selective riparian harvesting is the proposed action associated with the action alternatives that could adversely affect stream temperature. Stream temperature may be affected by the proposed selective riparian harvesting through decreases in angular canopy density (shade), sedimentation from increased rates of wind-thrown root wads, sedimentation from soil disturbances adjacent to riparian areas, and sedimentation from the installation of road-stream crossings. As a result of implementing Action Alternative B, an overall low risk of low direct and indirect impacts to the streamtemperature component of fisheries habitat is expected in South Fork Lost, Cilly, and Soup creeks. A moderate risk of low direct and indirect impacts is expected in Unnamed Creek.

\section{- Direct and Indirect Effects of Action -Attermative C on Habitat-Stream Temperature}

The overall anticipated direct and indirect impacts to the streamtemperature component of fish habitat in South Fork Lost, Cilly, Unnamed, and Soup creeks are expected to be similar or less than those described in Action Alternative B.

\section{- Direct and Imalirect Effects of Action -Alternative D on Habitat-Stream Temperature}

The overall anticipated direct and indirect impacts to the streamtemperature component of fish habitat are expected to be similar or less than those described in Action Alternative B, except a moderate risk of low direct and indirect impacts is expected in Cilly and Unnamed creeks.

\section{- Direct and Indirect Effects of Action -Atternative E on Habitat-Stream Temperature}

The overall anticipated direct and indirect impacts to the streamtemperature component of fish habitat are expected to be similar or less than those described in Action Alternative B, except a low risk of low direct and indirect impacts is expected in Unnamed Creek.

\section{HABITAT - CONNECTIVITY}

\section{- Direct and Indirect Effects of -Vo-Action -Alternative A on Habitat-Commectivity}

No direct or indirect impacts to the bull trout, westslope cutthroat trout, or other fisheries habitat component of connectivity in south Fork Lost, Cilly, Unnamed, or Soup creeks would occur beyond those described under EXISTING CONDITIONS. 


\section{- Direct and Indirect Effects of. Action -Alternative B, C, D, and E on Habitat - Commectivity}

No direct or indirect impacts to the fisheries habitat variable of connectivity are expected in South Fork Lost, Cilly, Unnamed, and Soup creeks under the action alternatives beyond those described in EXISTING CONDITIONS.

\section{CUMULATIVE EFFECTS FOR SOUTH FORK LOST, CILLY, UNNAMED, AND SOUP CREEKS}

Cumulative impacts are those collective impacts of the proposed action on the human environment when considered in conjunction with other past, present, and future actions related to the proposed action by location or generic type (75-1-220, $M C A)$. Future actions include statesponsored actions that are under concurrent consideration by any State agency through environmental analysis or permit processing procedures. The potential cumulative effects to fisheries in the Three Creeks Timber Sale Project area are determined by assessing the collective anticipated direct and indirect impacts, other related existing actions, and future actions affecting the fish-bearing streams in the project area.

\section{- Cumulative Effects of. Vo-.Action .Alternative .A on Fisheries}

Overall cumulative impacts to fisheries in South Fork Lost, Cilly, Unnamed, and Soup creeks are likely to be very low to low in addition to those collective impacts described in EXISTING CONDITIONS.

\section{- Cumulative Effects of Action .Alternatives B and Con Fisheries}

As a result of the selection of Action Alternatives $\mathrm{B}$ and $\mathrm{C}$, an overall moderate risk of low cumulative impacts to fisheries is expected in South Fork Lost, Cilly, and Soup creeks beyond those impacts described in EXISTING CONDITIONS. An overall moderate risk of a moderate cumulative impact is expected to fisheries in Unnamed Creek.

\section{- Cummative Effects of Action .Alternatives D on Fisheries}

As a result of the selection of Action Alternative D, an overall moderate risk of low cumulative impacts to fisheries is expected in South Fork Lost and Soup creeks beyond those impacts described in EXISTING CONDITIONS. An overall moderate risk of a moderate cumulative impact is expected to fisheries in Cilly and Unnamed creeks.

\section{- Cumulative Effects of Action Alternatives E on Fisheries}

As a result of the selection of Action Alternative $E$, an overall moderate risk of a low cumulative impact to fisheries is expected in the South Fork Lost, Cilly, Unnamed, and Soup creeks beyond those impacts described in the EXISTING CONDITIONS. 


\section{WILDLIFE ANALYSIS SUMMARY}

\section{EXISTING CONDITION}

\section{DISTURBANCE}

Motorized disturbances can affect the manner in which wildlife species use their environment. Highway 83 accounts for 4.8 miles, which cover 23.3 acres $(0.1$ percent of the analysis area); open roads account for 22.2 miles, which cover 37.7 acres ( 0.1 percent); and restricted roads (gated) account for 47.8 miles, which cover 81.1 acres $(0.3$ percent) of the 74.8 miles of roads covering 142.1 acres within the South Fork Lost Soup Grizzly Bear Subunit analysis area.

\section{COVERTYPE AND AGE CLASS}

Covertype and age class proportions provide a diversity of habitats for wildlife species. Based on the vegetation analysis conducted on the SLI data, mixed-conifer covertypes are overrepresented, while western larch/Douglas-fir and western white pine are underrepresented when compared to historic levels. In addition, stands on Swan River state Forest tend to be older than expected. These conditions likely lead to increased habitat for species that use older, more-dense stands that include a variety of tree species at the expense of species that use more-open stands dominated by shade-intolerant tree species.

\section{OLD-GROWTH-ASSOCIATED SPECIES}

Many wildlife species use old-growth habitats. Approximately 31 wildlife species are associated with oldgrowth forests in northwestern Montana. Based on the vegetation analysis of Swan river state Forest, over abundances of old growth occur in the Douglas-Fir, western white pine, mixed-conifer (includes stands dominated by western red cedar), and subalpine fire covertypes, while shortages occur in ponderosa pine, western larch/Douglas-fir, and lodgepole pine covertypes. Wildlife species typically associated with old growth in the covertypes that are overrepresented presumably benefited from additional habitat, while those associated with underrepresented types likely suffered from lower amounts of available habitat.

\section{FOREST CONNECTIVITY}

Movement corridors that maintain connectivity to adjacent habitat patches function to allow regular daily and seasonal movements, along with providing dispersal routes for juvenile animals. Generally, a high level of forest connectivity exists in the mountainous area, with many scattered openings existing on the portions of valley floor in the South Fork Lost Soup cumulativeeffects analysis area. Throughout the analysis area, forest connectivity is mostly maintained along the ridges, along the 4 major streams running from the mountains and draining into Swan River, and across third-order drainages (South Fork Lost and Soup creeks). These conditions provide a well-connected forest environment for animals to move relatively unimpeded through the cumulative-effects analysis area. However, several open roads in the valley bottom, including Highway 83, present human-caused impediments to connectivity.

\section{SNAG STRUCTURE}

Snags play an important role in forested ecosystems. Many forest birds aid in the dispersion of seeds and provide biological control of many forests insects. To assess effects to primary and secondary cavity-nesting species, the project area was used for the cumulativeeffects analysis area. Based on historic estimates, this cumulativeeffects analysis area is expected to contain 0.89 large snags per acre and 2.73 medium snags per acre, on average. The current average level of snag densities is estimated at 3.12 large and 5.86 medium snags per acre in the analysis area. 


\section{WILDLIFE ANALYSIS SUMMARY}

\section{COARSE WOODY DEBRIS}

Coarse woody debris provides structural diversity and promotes biological diversity by providing habitat for wildlife species. Presently, the cumulative-effects analysis area contains many stands with moderate to high levels of coarse woody debris. Within the analysis area, past harvests have been limited, thereby allowing increases in coarse woody debris. With the high incidence of insect and disease activities, these levels could continue to increase. High amounts of coarse woody debris provide habitat for a variety of wildlife species, which have likely gained habitat structure over time as stands age.

\section{CANADA LYNX}

Canada lynx are associated with subalpine fir forests in western Montana. The South Fork Lost Soup Subunit was used as the analysis area to assess the cumulative effects of this project on lynx. DNRC-managed lands support lynx habitat on 14,457 acres. Based on interpretation of aerial photographs, approximately 8,909 acres of adjacent lands provide forested habitats with greater than 40-percent canopy closure, which might support lynx habitat.

\section{GRAY WOLF}

Adequate habitat for wolves consists of areas with adequate prey and minimal human disturbance, especially at den and/or rendezvous sites. Wolves prey primarily on white-tailed deer and, to a lesser extent, elk and moose in northwest Montana. To analyze the cumulative effects to wolves, the South Fork Lost Soup Subunit was used. Currently, 31.2 percent of the analysis area exceeds 1 mile per square mile open-road density and 79 percent of the analysis area provides hiding cover. In addition, 49.6 miles of restricted road occur within the cumulative-effects analysis area.

\section{GRIZZLY BEAR}

In the Swan Valley, DNRC, USFS, Plum Creek Timber Company, and USFWS collaborated to cooperatively manage grizzly bear habitat and access under the SVGBCA. The South Fork Lost Creek Subunit becomes active during the 2007 through 2009 period. Presently, hiding cover in the South Fork Lost Creek Subunit comprises 82 percent of DNRC-managed, 75 percent of USFS, and 57 percent of Plum Creek Timber Company lands, averaging (weighted on acres) 79 percent for the subunit. A movingwindows analysis calculated 31.2 percent of the subunit exceeds 1 mile per square mile open-road density, while 44.7 percent of the analysis area exceeds 2 miles per square mile total-road density. An analysis of security core yielded that 37.8 percent of the analysis area met the definition for secure habitat.

\section{FISHER}

Fishers use a variety of successional stages, but are disproportionately found in stands with dense canopies and avoid openings or young forested stands. For cumulative-effects analysis purposes, the South Fork Lost Soup Grizzly Bear Subunit scale was used. Modeling indicates that 9,991 acres (77.2 percent of preferred covertypes) of upland and 731 acres (86.9 percent of preferred covertypes) of riparian potential fisher habitat are located on DNRCmanaged lands, while the interpretation of aerial photographs indicated an additional 6,452 acres of potential habitat on adjacent ownerships within the analysis area.

\section{PILEATED WOODPECKER}

Pileated woodpeckers play an important ecological role by excavating cavities that are used in subsequent years by many other 
species of birds and mammals. The South Fork Lost Soup Subunit provided the analysis area to consider the effects to pileated woodpeckers. On DNRC-managed lands, 6,130 acres of nesting habitat and 2,305 acres of foraging habitat currently exist. On adjacent ownerships, approximately 8,909 acres of habitat could occur.

\section{BIG GAME SPECIES}

Big game populations are dependent upon winter range to survive. To assess the cumulative effects to big game, winter range within the south Fork Lost Soup subunit was used. Changes caused by the proposed project could affect elk and mule deer winter range, but would not affect white-tailed deer winter range. The elk-mule deer composite winter range includes 6,613 acres; 5,434 acres occur on DNRC-managed lands and 1,179 acres occur on other ownership in the analysis area. Of the winter range within the DNRCmanaged ownership in the analysis area, 3,503 acres (64.5 percent) provide thermal cover. Based on interpretation of aerial photographs, approximately 1,100 acres ( 93.3 percent) on adjacent lands could provide thermal cover. When the winter range is analyzed for all ownerships in the analysis area, approximately 4,603 acres ( 69.6 percent) of thermal cover exists.

\section{ALTERNATIVE EFFECTS}

\section{- Direct, Indirect, and Cumulative Effects of. Vo- -Action .Altermative.A DISTURBANCE}

No additional disturbance along existing roads or within harvest units would occur, and no additional displacement of wildlife species would be expected.

\section{FOREST CONNECTIVITY}

No changes in connectivity would occur due to this project.

\section{AGE CLASS, COVERTYPE, AND OLD GROWTH}

No changes in the amount or distribution of these habitats would occur.

\section{SNAG STRUCTURE}

No changes in snag density would occur due to timber-harvesting activities proposed under this alternative. Tree mortality, especially in shade-tolerant species, could increase due to the age of the stands, insect infestations, disease infections, or other natural events. Public firewood gathering likely would continue to reduce snag densities, especially near open roads. Heavy retention of these snag densities is expected to benefit or retain current habitat for species that use deadwood resources in the short term.

\section{COARSE WOODY DEBRIS}

No changes in the amount, type, or distribution of coarse woody debris are expected; therefore, species that use coarse woody debris would maintain or gain additional habitat, which would represent a low to moderate benefit to these species.

\section{CANADA LYNX}

This alternative would not affect lynx habitat in the project area. Additionally, no other projects are expected to alter the distribution of habitat elements on state trust lands or adjacent ownerships. In the longer term, without disturbance, young foraging opportunities could decrease. However, mature stands that contain dense horizontal cover could offset or compensate for these losses.

\section{GRAY WOLF}

Existing vegetation and human access in the project area are not expected to be altered; therefore, no effects on wolves are expected under this alternative. 


\section{GRIZZLY BEAR}

No alteration of habitat attributes or increased human presence would occur; therefore, no changes in habitat use or the risk of humancaused mortality would be expected under this alternative.

\section{FISHER}

No fisher habitat would be altered under this alternative.

\section{PILEATED WOODPECKER}

No disturbance of pileated woodpeckers would occur. Nesting habitat structure would decline overtime and could lead to decreased reproduction in the analysis area. Therefore, under this alternative, pileated woodpecker habitat would increase through time, then decline, resulting in short- to mid-term moderate beneficial effects to pileated woodpeckers, but a longterm moderate effect due to the loss of nesting habitat.

\section{BIG GAME SPECIES}

Under this alternative, the levels of thermal cover would not be affected, thereby not affecting the ability of the available habitat to support the current elk and mule deer population.

\section{- Direct and Indirect Effects of.Action -Altermatives B, C, D, and E \\ DISTURBANCE}

Motorized disturbance would occur within an additional 1,795 to 1,998 acres of harvest units and 68 to 71 acres within existing roads and newly constructed restricted roads. The increased vehicle traffic associated with each alternative on the open roads and highway would likely contribute negligibly to the displacement effects already occurring. The displacement effects due to motorized disturbance may extend for some distance away from the source and may vary by species and individual animals.

\section{COVERTYPE AND AGE CLASS}

Under all action alternatives, a portion of the harvested stands would be converted from mixedconifer covertypes to shadeintolerant covertypes (western larch/Douglas-fir and western white pine); also, average age would be reduced. All alternatives move stands toward historic proportions of covertypes; however, historic age distributions would not necessarily be retained within those covertypes. These changes are expected to result in beneficial effects for species that use shade-intolerant covertypes; however, these benefits may be delayed due to conversion of covertypes necessitating a conversion of older-aged stands to younger-aged stands. In the short term, species that use older, denser stands with a variety of tree species would be negatively impacted; however, these species would likely still have at least as much, if not more, habitat available than would be expected under historic conditions. Action Alternative $\mathrm{C}$ would result in a higher rate of conversion from mixed-conifer to western larch/Douglas-fir covertypes. Additionally, Action Alternative C would retain a higher proportion of older-aged stands. Action Alternatives $\mathrm{D}, \mathrm{B}$, and $\mathrm{E}$, respectively, convert less acreage of mixed-conifer covertypes to western larch/Douglas-fir covertypes and retain lesser proportions of older-aged stands.

\section{OLD-GROWTH-ASSOCIATED SPECIES}

Under all action alternatives, some amount of stand-replacement-type harvests would remove old-growth habitats. Following harvesting, all alternatives would retain proportions of old-growth habitat that fall within the range of 


\section{WILDLIFE ANALYSIS SUMMARY}

historical amounts of old growth (15 to 52 percent) on Swan River State Forest. Therefore, the risk of adverse effects due to a lack of old-growth habitats is expected to be low. However, the relative risk of affecting old-growth associated species is greater under Action Alternative $\mathrm{D}$ than under Action Alternatives $C, B$, and $E$, respectively.

\section{FOREST CONNECTIVITY}

Each alterative could alter connectivity of mature forest patches by creating gaps and producing large openings in the uplands. However, the project design for each alternative includes mitigation measures to maintain forest connectivity along the 4 major streams (Soup, Unnamed, Cilly, South Fork Lost creeks) in the project area. Therefore, this alternative would result in minor risk of preventing movement through the project area.

\section{SNAG STRUCTURE}

In all units proposed under these alternatives, decreases in feeding and nesting sites are expected to occur due to the harvesting of snags. Within the harvest units, a minimum of 2 large snags per acre would be retained, which approximates the historic densities. Nesting and foraging sites would be reduced to near average historic levels within the harvest units $(1,795$ to 1,998 acres), resulting in a low risk of decreasing survival or reproduction of species that need large snags to fulfill their life requirements. However, the heavy reduction in density of medium- and small-sized snags within the harvest units could result in sight specific decreased nesting and foraging opportunities for cavity-nesting species. These effects are likely to last 80 to 100 years in regeneration units and 20 to 50 years in commercial-thin units, at which time leave trees and regeneration could start appreciably contributing to snag development.

\section{COARSE WOODY DEBRIS}

Under all alternatives, coarse woody debris would be retained at approximately 15 tons per acre within the harvest units. In some cases, coarse woody debris could increase through harvesting; however, most of this material would be made from pieces of cull boles, limbs, and tops. Few intact trees would be retained. Following harvesting, coarse woody debris would provide some wildlife habitat; however, species that use large pieces of coarse woody debris would likely lose a portion of their habitat components within the harvest units.

\section{CANADA LYNX}

Seedtree, seedtree-with-reserves, and shelterwood harvest

prescriptions are expected to remove canopy and horizontal cover to prepare for regenerating trees. These alternatives would convert between 424 and 618 acres to temporary non-lynx habitat. In the short term, lynx would likely avoid harvest units that were converted to temporary non-lynx habitat, resulting in habitat usage shifts away from the regeneration units. Use of the commercial-thin units is expected to continue at some level. In the longer term (10 to 20 years), the temporary non-lynx habitat is expected to regenerate to young foraging habitat, thereby providing additional forage habitat.

\section{GRAY WOLF}

Under all action alternatives, a range of 8.4 to 15.8 miles of restricted road would be constructed to harvest proposed units. Timber harvesting would remove between 1,203 and 1,351 acres of hiding cover for a 


\section{WILDLIFE ANALYSIS SUMMARY}

duration of 10 to 20 years, depending upon whether an action alternative were chosen, and which one. Taken together, the mitigation measures outlined in the SVGBCA and the Rules are expected to result in a low risk for human/wolf conflicts or increased wolf mortality if wolves use the harvest units.

\section{GRIZZLY BEAR}

Under each action alternative, a range of 1,203 to 1,351 acres of hiding cover would be removed by the implementation of seedtree and shelterwood silvicultural prescriptions, and 8.4 to 13.3 miles of new permanent roads and 3.9 to 6.6 miles of new temporary roads would be constructed. All new permanent roads, except 1.7 miles, would be managed as restricted. The 1.7 miles of new permanent road would be constructed to reroute the existing South Fork Lost Creek Road away from South Fork Lost Creek. Approximately 1.3 miles of the existing South Fork Lost Creek Road would then be abandoned, resulting in a $0.4 \mathrm{mile}$ total increase in open road.

\section{FISHER}

Each alternative would harvest in potential fisher habitat. The harvesting proposed under all alternatives would result in reduced quantity or quality of fisher habitat by 1,760 to 1,924 acres, depending on if an action alternative were chosen, and which one. All alternatives pose a moderate risk of preventing or reducing habitat use in the harvest units, which would result in habitat shifts away from these areas and into other stands within the analysis area.

\section{PILEATED WOODPECKER}

Under all action alternatives, between 1,051 and 1,559 acres of potential nesting and 140 to 394 additional acres of potential woodpecker foraging habitat would be modified. However, 2 large snags per acre would be retained to approximate the average historic abundance of snags; therefore, adequate nesting and foraging structure would likely be retained. Since pileated woodpecker density is positively correlated with the amount of dead and/or dying wood in a stand, pileated woodpecker densities in the analysis area could be expected to be reduced by all alternatives. In the longer term, seral species would be planted under this alternative and could provide pileated woodpecker habitat in the distant future (100 to 150 years).

\section{BIG GAME SPECIES}

Each action alternative proposes to harvest between 675 and 895 acres of thermal cover. These harvests would remove between 514 and 601 acres of thermal cover, while retaining greater than 40-percent canopy coverage within the remaining harvest units. These reductions are expected to result in a moderate risk of habitat shifts of wintering elk and deer away from the treated areas. The risk of avoidance would increase in relation to greater snow accumulations in these areas.

\section{- Cumulative Effects of.Action .Atternative B, C, D, and E}

\section{DISTURBANCE}

In the longer term, the new construction of permanent restricted road (15 to 27 acres) constructed under each alternative would increase the ability for administrative motorized and nonmotorized access. Other DNRC projects could add approximately 125 acres $(0.4$ percent of the analysis area) to the amount of habitat affected if these projects ran concurrently with the Three Creeks Timber Sale Project. The use of these roads and harvesting 


\section{WILDLIFE ANALYSIS SUMMARY}

activities are expected to be less than 30 days. Therefore, the cumulative effects of any alternative would likely result in short-term negligible increases in displacement.

\section{FOREST CONNECTIVITY}

All action alternatives could disrupt upland connectivity. However, mitigation measures included in each alternative and in stands not proposed for harvesting would retain connectivity along the 4 major creeks and along ridges throughout the analysis area. Activities that could affect forested connectivity in the analysis area include open-road use, DNRC salvage harvesting, potential timber harvesting on adjacent lands, and tree mortality due to insect infestations and disease infections. Considered in conjunction with other past, present, and future activities, any of the proposed action alternatives would likely result in minor cumulative effects to connectivity.

\section{COVERTYPE AND AGE CLASS}

The effects of each action alternative would be cumulative to the trend toward historic conditions resulting in increased amounts of western larch/Douglasfir and western white pine and decreased amounts of mixed-conifer covertypes. Wildlife species that use western larch/Douglas-fir and western white pine covertypes would benefit from increased habitat, while those species that use mixedconifer stands would lose habitat. However, these benefits would be delayed for species that use olderaged stands of western larch/Douglas-fir covertypes because many of these covertype conversions require regeneration harvests.

\section{OLD GROWTH}

If an action alternative were chosen, additional treatments would be cumulative in their effects on wildlife to past harvests in the project area, harvests on adjacent ownerships, and past management across Swan River State Forest. No other harvests in old-growth stands are concurrently being considered or planned in the foreseeable future within the South Fork Lost Soup grizzly bear subunit. Therefore, only the old-growth stands proposed for harvest would be altered, resulting in the proportion of old-growth stands on Swan River State Forest occurring within estimated historic

proportions. Species that use oldgrowth habitat would be effected by reduced habitat availability, however, adequate habitat would be retained. Species that do not use old growth for meeting life requisites would either benefit or be uninfluenced from proposed treatments.

\section{SNAG STRUCTURE}

Under each action alternative, large- and medium-sized snags would be harvested from harvest units within the analysis area. Snag retention within the cumulativeeffects analysis area would average between 4.81 and 5.13 medium snags and 2.78 and 2.85 large snags per acre following harvesting. No other projects are planned at the present time or within the foreseeable future within the analysis area (project area). Public firewood cutting occurs in the analysis area and is generally confined to sites adjacent to open roads. Considered in conjunction with other past, present, and future activities, each of the proposed action alternatives would likely result in minor cumulative effects to snag structure due to the retention of high densities of snags (large and medium size classes) in adjacent stands and retention of the historical average density of large snags within the harvest units. 


\section{WILDLIFE ANALYSIS SUMMARY}

\section{COARSE WOODY DEBRIS}

No additional effects to those listed under direct and indirect effects are expected because no other activities are planned within the cumulative-effects analysis area (project area). The current levels of coarse woody debris in adjacent stands could mostly offset the changes expected within the harvests units. Additionally, the trees and snags retained in both harvested and unharvested stands would continue to provide a source of coarse-woody-debris recruitment over time. When past, present, and future actions were considered, there is a low risk that the changes in coarse woody debris projected under each alternative would result in substantial decreases in survival or reproduction of species that require these attributes to fulfill their life requirements. However, the risk level is higher in Action Alternative $E$, than in Action Alternatives $D, B$, and $C$, respectively.

\section{CANADA LYNX}

All action alternatives would result in a short-term reduction in Canada lynx habitat. However, adequate amounts of habitat in suitable proportions of habitat (denning and foraging) would be retained. In 10 to 20 years, this alternative could result in increased young foraging habitat that could provide increased snowshoe prey availability for 10 to 30 years. Therefore, this alternative is expected to result in a low risk of reducing the ability of a lynx to survive and reproduce in the area in the short term (10 to 20 years), and could benefit lynx in 10 to 20 years by increasing foraging habitat as the harvested stands regenerate and provide snowshoe hare habitat.

\section{GRAY WOLF}

Under all action alternatives, open-road density would increase, hiding cover would decrease, and restricted roads would be constructed, which could affect wolf use and ability to survive in the analysis area. All action alternatives protect key sites, retain considerable levels (74.7 to 75.2 percent of the analysis area) of hiding cover, maintain approximately the same level of public motorized access (small location shift of South Fork Lost Creek Road), restrict contractors from carrying firearms while on duty, and are not expected to affect big game populations (refer to BIG GAME analysis) in the analysis area. Therefore, each alterative presents a low risk to increasing mortality to wolves or substantially reducing their prey in the analysis area.

\section{GRIZZLY BEAR}

Under all action alternatives, the amount of hiding cover retained in the subunit would be reduced from 79.0 percent to between 74.7 and 75.2 percent, depending on whether an action alternative were chosen, and which one. The rerouting of the South Fork Lost Creek Road and abandonment of portions of the existing roads would result in an increase in open-road density from 31.2 to 31.5 percent. Under all action alternatives, the proportion of area affected by total-road density would increase from 53.2 percent to between 56.9 and 59.9 percent, and secure habitat would decrease from 32.2 percent to between 28.9 to 30.8 percent, depending on whether an action alternative were chosen, and which one.

Therefore, each action alternative would result in small proportional reductions of hiding cover resulting in negligible risk of reducing availability of grizzly 


\section{WILDLIFE ANALYSIS SUMMARY}

bear habitat or increasing mortality risks to bears using the analysis area. The increase in open-road density is slight and within the same area already affected by this road; therefore, any additional risk of increased mortality or decreased reproduction due to this change is likely to be negligible. The use of the new restricted roads that affect totalroad density and secure habitat could increase habitat avoidance; however, the use of these additional roads are low and these increases are not constrained by the SVGBCA. Therefore, minor additional risks to grizzly bears are expected under all action alternatives.

Salvage harvests on an additional 120 acres are not expected to alter hiding cover, so no additional changes in hiding cover are expected on DNRC-managed lands. other cooperators (USFS and Plum Creek Timber Company) do not have plans for projects in this subunit during the 2007 through 2009 active period. Therefore, this alternative would result in small proportional reductions of hiding cover, resulting in a negligible risk of reducing availability of grizzly bear habitat or increasing mortality risks to bears using the analysis area.

\section{FISHER}

On DNRC-managed lands, available fisher habitat in the uplands would decline from 9,991 acres to between 8,712 and 8,806 acres (an 11.9- to 12.8-percent reduction in habitat). Additionally, habitat quality would be reduced on between 487 and 648 acres ( 4.9 to 6.5 percent of existing habitat). No changes in the amount of fisher habitat associated with streams would occur, but 55 to 91 acres of habitat associated with riparian areas would be reduced in quality through timber harvesting. On adjacent ownerships, an additional 6,452 acres of fisher habitat could be present, thereby adding to the amount of fisher habitat in the analysis area. DNRC is concurrently considering salvage harvests on an additional 120 acres in the analysis area. No fisher habitat is expected to be harvested from adjacent lands during the 2007 through 2009 period. Firewood cutting would be limited to areas near open roads. Due to the small area affected by these additional activities, any additional changes in fisher habitat are expected to be minor. Considered in conjunction with other past, present, and future activities, any of the proposed action alternatives would likely result in a low risk of cumulative effects to fishers.

\section{PILEATED WOODPECKER}

Potential habitat would be reduced to between 6,734 and 7,027 acres (a 16.7 - to 20.1-percent reduction from the existing 8,435 acres) on DNRC-managed lands in the cumulative-effects analysis area. Although potential habitat would be reduced under these alternatives, the remaining habitat consists of high densities of snags that provide forage and nesting structure, which could offset the losses experienced in the harvest units. Additionally, estimated historic densities of large snags (2 snags per acre) would be retained within the harvest units to provide foraging and nesting structure when the canopy closure recovers to the point of allowing pileated woodpecker use. In addition, approximately 3,411 acres of potential pileated woodpecker habitat could exist on adjacent lands. Each alternative is expected to remove between 11.9 and 18 percent of the existing nesting habitat, while reducing quality on an additional 5.2 to 7.3 percent of the available habitat. The reduction in nesting habitat would 


\section{WILDLIFE ANALYSIS SUMMARY}

reduce nesting and foraging habitat available to pileated woodpeckers that could result in a low risk of reducing the use and reproduction of pileated woodpeckers in the analysis area in the short term.

\section{BIG GAME SPECIES}

Each alternative would reduce the amount of thermal cover to between 2,989 and 2,903 acres (a 14.7- to 17.2-percent reduction) in the cumulative-effects analysis area. Commercial-thin prescriptions would reduce the quality of thermal cover on another 3.1 to 8.4 percent of the existing thermal cover. On DNRC-managed lands, enough thermal cover would be retained under any alternative to provide adequate winter-range habitat for elk and mule deer; therefore, a low risk to the reduction of carrying capacity is expected under any action alternative. In addition to the thermal cover found on DNRC-managed lands, an additional 1,100 acres of potential thermal cover occurs on adjacent ownerships within the cumulative-effects analysis area. When these acres are considered, the existing thermal cover is 69.6 percent of the total winter range. Under all alternatives, thermal cover would be reduced to between 60.5 and 61.8 percent of the winter range. Considered in conjunction with other past, present, and future activities, any of the proposed action alternatives would result in a low risk of reducing winter-range carry capacity for mule deer and elk. 


\section{SOILS ANALYSIS SUMMARY}

\section{INTRODUCTION}

The Swan River watershed is a valley formed by glaciers and river processes. The dominant soil types found in the project area are deep glacial tills derived from argillite, siltite, and limestone from the Belt Supergroup. Upper slopes and ridges are weathered bedrock scoured by glaciers. This analysis addresses the issue that timber harvesting and associated activities may affect soil conditions in the proposed project area.

\section{ANALYSIS METHODS}

Soil effects and conditions will be analyzed by evaluating the current levels of soil disturbance in the proposed project area through the use of aerial-photo interpretation and ocular estimates based on field review of existing and proposed harvest units. Analysis will also include assessing slope stability with aerial-photo interpretation and field review of proposed roads and harvest units.

Estimated effects of proposed activities will be assessed based on findings of DNRC soil monitoring. See APPENDIX G - SOILS ANALYSIS for a more detailed description of DNRC soil monitoring, methods, and results.

\section{ANALYSIS AREA}

The analysis area for evaluating soil effects will include stateowned land within the Three Creeks Timber Sale Project area. The proposed project area is found within the South Fork Lost Creek, Cilly Creek, and Soup Creek watersheds.

\section{EXISTING CONDITIONS}

A list of soil types found in the Three Creeks Timber Sale Project area and their associated management implications is found in TABLE III11 - SOIL MAP UNIT DESCRIPTIONS FOR THE THREE CREEKS PROJECT AREA.
Several areas of past slope instability were identified in the proposed project area. These areas are mostly small and a result of several site-specific conditions. These conditions include a combination of the glacial till, steep slopes, shallow depth to bedrock, and avalanche chutes; in one case, past management may have been a contributing factor. A more detailed description of past slope instability and recommended measures to mitigate for possible instability can be found in the project file at the Swan River state Forest office.

The proposed project area is approximately 10,344 acres and is located in Swan River state Forest. In the proposed project area, DNRC has conducted timber harvesting since the 1950s. Based on review of aerial photos from the $1960 \mathrm{~s}$ through the present, section record cards, and timber sale records, approximately 1,463 acres (or about 14 percent of the acres in the project area) have been harvested on State land within the proposed project area using a combination of ground-based and cable-yarding harvest methods.

Based on field review of past harvest areas within the proposed project area, existing soils impacts are estimated to be 10 percent or less of the previously harvested areas. Field reconnaissance using sight estimates shows that existing skid trails are adequately spaced, many of the existing trails from past management are well vegetated, and past impacts are improved from frost and vegetation. Minimal evidence of isolated soil erosion was observed on short pitches of existing skid trails and landings within the project area. 


\section{ALTERNATIVE EFFECTS}

DIRECT AND INDIRECT EFFECTS

\section{- Direct and Indirect Effects of . No-o-Action} -Atternative o to Soils

Direct or indirect impacts would not occur with this alternative.

\section{- Divect and Indivect Effects Common to Action -Alternatives B, C, D, and E to Soils}

The estimated range of soil impacts for all of the action alternatives is from 7 to 9 percent, and no individual harvest unit is expected to have impacts greater than 15 percent. TABLE III-10 - SUMMARY OF DIRECT EFFECTS OF ALL ALTERNATIVES ON SOILS WITH SUMMER HARVESTING summarizes the expected impact to soils. Fifteen percent impacts fall within the range of impacts analyzed for in the EXPECTED FUTURE CONDITIONS section of the SFLMP (DNRC 1996). A description of specific measures to maintain this level of impacts is found in APPENDIX G - SOILS ANALYSIS.

\section{- Direct and Indirect effects of .Action -Alternative B to Soils}

This alternative would have direct impacts on an estimated 8.7 percent of the area in proposed harvest units. This includes skid trails, landings, cable-yarding corridors, and impacted spots. Direct impacts to soils would include compaction and displacement resulting from use of ground-based equipment to skid logs on approximately 891 acres, cable yarding on approximately 557 acres, and landings from helicopter yarding. TABLE III-10 - SUMMARY OF DIRECT EFFECTS OF ALL ALTERNATIVES ON SOILS WITH SUMMER HARVESTING summarizes the expected impact to soils.

Ground-based site preparation and road construction would also generate direct impacts to the soil resource. Site-preparation disturbance would be intentionally done to promote reforestation of the site, and the impacts would be considered light. These activities and the harvesting activities listed above would leave up to 8.7 percent of the proposed harvest units in an impacted condition. This level is below the range analyzed for in the EXPECTED FUTURE CONDITIONS section of the SFLMP, and well within the 20-percent impacted area established as a level of concern in the SFLMP (DNRC 1996).

\section{- Direct and Indirect Effects of.Action -Alternative C to Soils}

This alternative would have direct impacts on an estimated 8.6 percent of the area in proposed harvest units. This includes skid trails, landings, cable-yarding corridors, and impacted spots. Direct impacts to soils would include compaction and displacement resulting from the use of ground-based equipment to skid logs on approximately 823 acres, cable yarding on approximately 543 acres, and landings from helicopter yarding. TABLE III-10 - SUMMARY OF DIRECT EFFECTS OF ALL ALTERNATIVES ON SOILS WITH SUMMER HARVESTING summarizes the expected impact to soils.

Ground-based site preparation and road construction would also generate direct impacts to the soil resource. Site-preparation disturbance would be intentionally done to promote reforestation of the site, and the impacts would be considered light. These activities and the harvesting activities listed above would leave up to 8.6 percent of the proposed harvest units in an impacted condition. This level is below the range analyzed for in the EXPECTED FUTURE CONDITIONS section of the SFLMP, and well within the 20-percent impacted area established as a level of concern in the SFLMP (DNRC 1996). 


\section{SOILS ANALYSIS SUMMARY}

\section{- Direct and Indirect Effects of .Action -Atternative D to Soils}

This alternative would have direct impacts on an estimated 7.2 percent of the area in proposed harvest units. This includes skid trails, landings, cable-yarding corridors, and impacted spots. Direct impacts to soils would include compaction and displacement resulting from use of ground-based equipment to skid logs on approximately 699 acres, cable yarding on approximately 679 acres, and landings from helicopter yarding. TABLE III-10 - SUMMARY OF DIRECT EFFECTS OF ALL ALTERNATIVES ON SOILS WITH SUMMER HARVESTING summarizes the expected impact to soils.

Ground-based site preparation and road construction would also generate direct impacts to the soil resource. Site-preparation disturbance would be intentionally done to promote reforestation of the site, and the impacts would be considered light. These activities and the harvesting activities listed above would leave up to 7.2 percent of the proposed harvest units in an impacted condition. This level is below the range analyzed for in the EXPECTED FUTURE CONDITIONS section of the SFLMP, and well within the 20-percent impacted area established as a level of concern in the SFLMP (DNRC 1996).

\section{- Direct and Indirect Effects of Action -Atternative E to Soils}

This alternative would have direct impacts on an estimated 7.6 percent of the area in proposed harvest units. This includes skid trails, landings, cable-yarding corridors, and impacted spots. Direct impacts to soils would include compaction and displacement resulting from use of ground-based equipment to skid logs on approximately 786 acres, cable yarding on approximately 629 acres, and landings from helicopter yarding. TABLE III-10 - SUMMARY OF DIRECT EFFECTS OF ALL ALTERNATIVES ON SOILS WITH SUMMER HARVESTING summarizes the expected impact to soils.

Ground-based site preparation and road construction would also generate direct impacts to the soil resource. Site-preparation disturbance would be intentionally done to promote reforestation of the site, and the impacts would be considered light. These activities and the harvesting activities listed above would leave up to 7.6 percent of the proposed harvest units in an impacted condition. This level is below the range analyzed for in the EXPECTED FUTURE CONDITIONS section of the SFLMP, and well within the 20-percent impacted area established as a level of concern in the SFLMP (DNRC 1996). 
SOILS ANALYSIS SUMMARY

TABLE III-10 - SUMMARY OF DIRECT EFFECTS OF ALL ALTERNATIVES ON SOILS WITH SUMMER HARVESTING

\begin{tabular}{|c|c|c|c|c|c|}
\hline \multirow{2}{*}{$\begin{array}{l}\text { DESCRIPTION OF } \\
\text { PARAMETER }\end{array}$} & \multicolumn{5}{|c|}{ ALTERNATIVE } \\
\hline & $\mathbf{A}$ & B & C & D & $\mathbf{E}$ \\
\hline Acres of harvest & 0 & 1,856 & 1,752 & 1,941 & 1,966 \\
\hline Acres of helicopter yarding & 0 & 408 & 386 & 563 & 551 \\
\hline Acres of tractor yarding & 0 & 891 & 823 & 699 & 786 \\
\hline $\begin{array}{l}\text { Acres of skid trails and } \\
\text { landings }\end{array}$ & 0 & 178 & 165 & 140 & 157 \\
\hline Acres of cable yarding & 0 & 557 & 543 & 679 & 629 \\
\hline Acres of yarding corridors ${ }^{2}$ & 0 & 56 & 54 & 68 & 63 \\
\hline Acres of moderate impacts ${ }^{3}$ & 0 & 162 & 151 & 139 & 149 \\
\hline $\begin{array}{l}\text { Percent of harvest area } \\
\text { with impacts }\end{array}$ & $0 \%$ & $8.7 \%$ & $8.6 \%$ & $7.2 \%$ & $7.6 \%$ \\
\hline \multicolumn{6}{|c|}{$\begin{array}{l}120 \text { percent of ground-based area } \\
25 \text { to } 10 \text { percent of cable yarding units }\end{array}$} \\
\hline
\end{tabular}

\section{CUMULATIVE EFFECTS}

\section{- Cumulative Effects of. NorAction .Alternative -A to Soils}

This alternative would have no additional cumulative impacts on soil conditions.

\section{- Cumulative Effects to Soils Common to Action -Attermatives $\boldsymbol{B}$ and $C$}

Both of these alternatives would enter one stand (approximately 19 acres) where previous timber management has occurred. Cumulative impacts may include compaction, displacement, and erosion on additional trails beyond those already existing from past entries. Additional compaction and displacement may occur on existing trails from reuse. Any improvement of compaction from frost action and vegetation growth is erased if an existing trail is reused by equipment, and the effects may be more extensive with repeated use.

Based on soil monitoring conducted on state trust land in Swan River State Forest, DNRC expects cumulative effects to soil conditions to be 15 percent or less of harvested areas, including impacts from past harvesting.
This value is within or below the range analyzed for in the EXPECTED FUTURE CONDITIONS section of the SFLMP and well within the 20percent impacted area established as a level of concern in the SFLMP (DNRC 1996).

In the remaining previously unharvested stands, cumulative effects to soil conditions from multiple entries would be the same as those listed under DIRECT AND INDIRECT EFFECTS. For slash treatment, equipment would pile slash and limit site preparation to less than 30-percent scarified soils within regeneration harvest units. Scarification to mix the surface duff to promote the establishment of conifers, but not remove surface soil, is considered a nondetrimental effect to soils.

- Cumulative Effects of Action. Alternative D to Soils

This alternative would enter one stand (approximately 8 acres) where previous timber management has occurred. Cumulative impacts may include compaction, displacement, and erosion on additional trails beyond those already existing from past entries. Additional compaction 


\section{SOILS ANALYSIS SUMMARY}

and displacement may occur on existing trails from reuse. Any improvement of compaction from frost action and vegetation growth is erased if an existing trail is reused by equipment, and the effects may be more extensive with repeated use.

Based on soil monitoring conducted on state trust land in Swan River State Forest, DNRC expects cumulative effects to soil conditions to be 15 percent or less of harvested areas, including impacts from past harvesting. This value is within or below the range analyzed for in the EXPECTED FUTURE CONDITIONS section of the SFLMP and well within the 20percent impacted area established as a level of concern in the SFLMP (DNRC 1996).

In the remaining previously unharvested stands, cumulative effects to soil conditions from multiple entries would be the same as those listed under DIRECT AND INDIRECT EFFECTS. For slash treatment, equipment piling of slash and site preparation would be limited to less than 30-percent scarified soils within regeneration harvest units. Scarification to mix the surface duff to promote conifer establishment, but not remove surface soil, is considered a nondetrimental effect to soils.

\section{- Cumulative Effects of Action .Alternative E to} Soils

This alternative would enter 2 stands (combined 27 acres) where previous timber management has occurred. Cumulative impacts may include compaction, displacement, and erosion on additional trails beyond those already existing from past entries. Additional compaction and displacement may occur on existing trails from reuse. Any improvement of compaction from frost action and vegetation growth is erased if an existing trail is reused by equipment, and the effects may be more extensive with repeated use.

Based on soil monitoring conducted on state trust land in Swan River State Forest, DNRC expects cumulative effects to soil conditions to be 15 percent or less of harvested areas, including impacts from past harvesting. This value is within or below the range analyzed for in the EXPECTED FUTURE CONDITIONS section of the SFLMP, and well within the 20percent impacted area established as a level of concern in the SFLMP (DNRC 1996).

In the remaining previously unharvested stands, cumulative effects to soil conditions from multiple entries would be the same as those listed under DIRECT AND INDIRECT EFFECTS. For slash treatment, equipment would pile slash and limit site preparation to less than 30-percent scarified soils within regeneration harvest units. Scarification to mix the surface duff to promote conifer establishment, but not remove surface soil, is considered a nondetrimental effect to soils. 


\begin{tabular}{|c|c|c|c|c|c|c|c|c|c|c|c|}
\hline \multicolumn{12}{|c|}{ SOILS ANALYSIS SUMMARY } \\
\hline \multirow{3}{*}{ 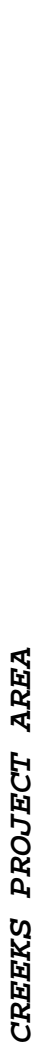 } & 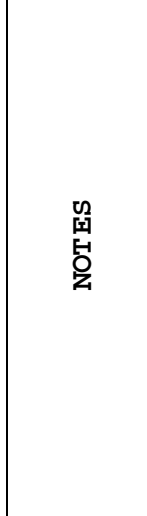 & 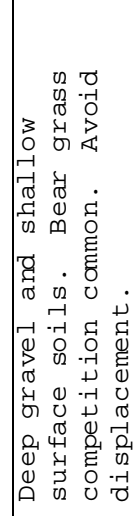 & 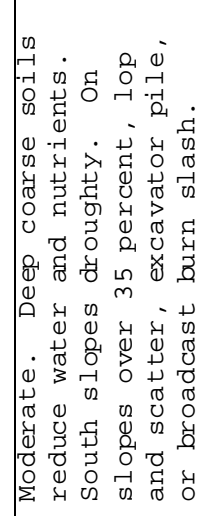 & 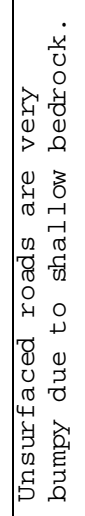 & 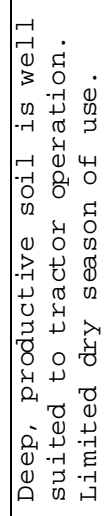 & 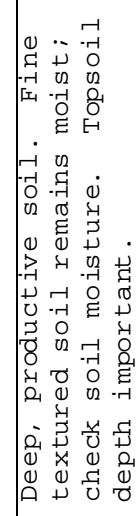 & 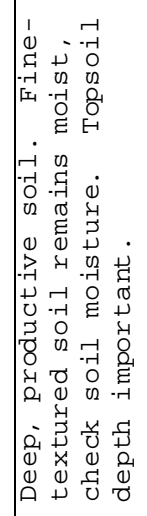 & 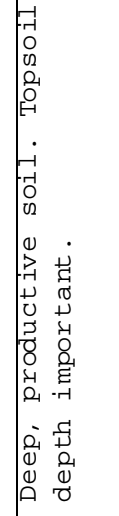 & 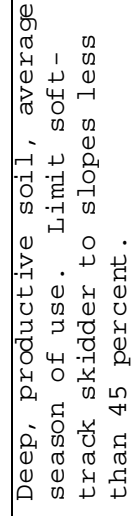 & 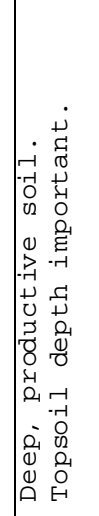 & 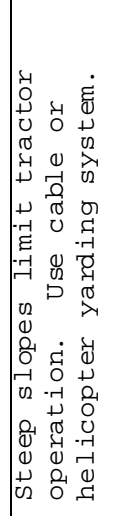 \\
\hline & 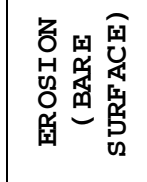 & 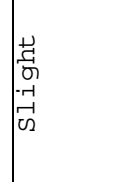 & $\begin{array}{l}0 \\
1 \\
0 \\
0 \\
4 \\
0 \\
0 \\
0 \\
0\end{array}$ & $\begin{array}{l}0 \\
0 \\
0 \\
0 \\
0 \\
0 \\
0 \\
0 \\
\sum\end{array}$ & 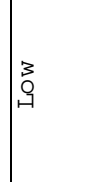 & $\begin{array}{l}0 \\
1 \\
0 \\
0 \\
4 \\
0 \\
0 \\
0 \\
0 \\
\Sigma\end{array}$ & $\begin{array}{l}0 \\
0 \\
0 \\
0 \\
4 \\
0 \\
0 \\
0 \\
0 \\
0 \\
\Sigma\end{array}$ & $\mid \begin{array}{l}3 \\
9 \\
9\end{array}$ & 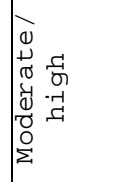 & $\begin{array}{l}0 \\
0 \\
4 \\
0 \\
4 \\
4 \\
0 \\
0 \\
0 \\
\Sigma \\
\Sigma\end{array}$ & $\begin{array}{l}1 \\
0 \\
0 \\
0 \\
4 \\
0 \\
0 \\
0 \\
0 \\
2\end{array}$ \\
\hline & 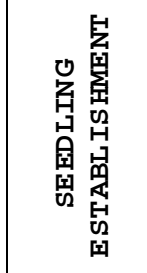 & 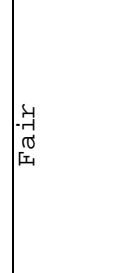 & 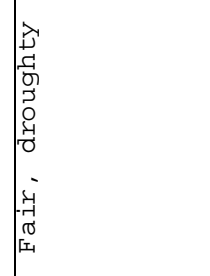 & $\begin{array}{l}y \\
0 \\
0 \\
0 \\
\text { O1 }\end{array}$ & $\begin{array}{l}0 \\
0 \\
0 \\
0\end{array}$ & $\begin{array}{l}\delta \\
0 \\
0 \\
0\end{array}$ & $\begin{array}{l}0 \\
0 \\
0 \\
0\end{array}$ & $\begin{array}{l}0 \\
0 \\
0 \\
0\end{array}$ & $\begin{array}{l}0 \\
0 \\
0 \\
0\end{array}$ & $\begin{array}{l}0 \\
0 \\
0 \\
0\end{array}$ & 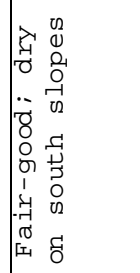 \\
\hline 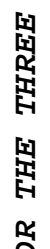 & 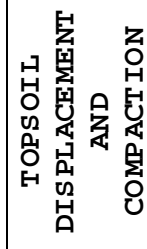 & $\begin{array}{l}0 \\
1 \\
\pi \\
0 \\
0 \\
0 \\
0 \\
0 \\
\Sigma\end{array}$ & $\begin{array}{l}0 \\
1 \\
0 \\
4 \\
4 \\
0 \\
0 \\
0 \\
2\end{array}$ & $\begin{array}{l}0 \\
1 \\
r \\
0 \\
4 \\
0 \\
0 \\
0 \\
\Sigma\end{array}$ & 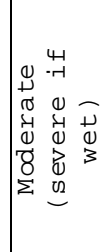 & $\begin{array}{l}0 \\
0 \\
0 \\
0 \\
4 \\
0 \\
0 \\
0 \\
0 \\
\Sigma \\
\Sigma\end{array}$ & $\begin{array}{l}0 \\
1 \\
0 \\
0 \\
4 \\
0 \\
0 \\
0 \\
0 \\
\Sigma\end{array}$ & 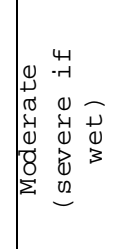 & 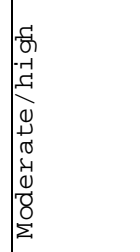 & $\begin{array}{l}0 \\
y \\
0 \\
0 \\
4 \\
0 \\
0 \\
0 \\
\Sigma \\
\Sigma\end{array}$ & 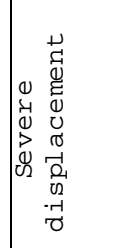 \\
\hline 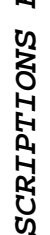 & 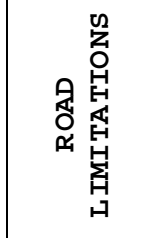 & 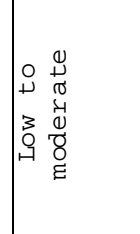 & 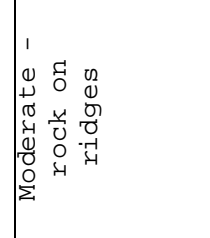 & $\begin{array}{l}0 \\
0 \\
0 \\
0 \\
0 \\
0 \\
0 \\
0 \\
\vdots \\
3 \\
0 \\
1\end{array}$ & 旁 & $\begin{array}{l}0 \\
+ \\
0 \\
0 \\
4 \\
0 \\
0 \\
0 \\
0 \\
\Sigma\end{array}$ & $\begin{array}{l}0 \\
1 \\
0 \\
0 \\
4 \\
0 \\
0 \\
0 \\
0 \\
\Sigma\end{array}$ & $\mid \begin{array}{l}3 \\
0 \\
9 \\
1\end{array}$ & 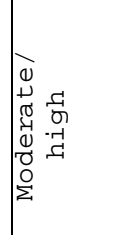 & $\begin{array}{l}0 \\
0 \\
0 \\
0 \\
4 \\
0 \\
0 \\
0 \\
0 \\
\Sigma\end{array}$ & $\mid \begin{array}{l}0 \\
+ \\
0 \\
0 \\
4 \\
0 \\
0 \\
0 \\
\Sigma \\
\Sigma\end{array}$ \\
\hline 点 & 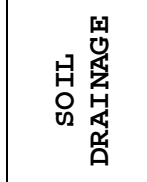 & $\begin{array}{ll} & 0 \\
& 0 \\
7 & 0 \\
0 & -7 \\
0 & -7 \\
3 & \pi \\
3 & 0 \\
0 & 0\end{array}$ & $\begin{array}{ll}1 & 0 \\
0 & 0 \\
0 & -1 \\
0 & 0 \\
3 & 0 \\
0 & 0 \\
0 & 0 \\
0 & 0 \\
0 & x \\
0 & 0\end{array}$ & $\begin{array}{ll}0 & -1 \\
0 & -1 \\
0 & -1 \\
04 & 0 \\
0 & 3 \\
0 & 3 \\
0 & 0 \\
0 & +1\end{array}$ & $\begin{aligned} & 0 \\
& 0 \\
& 7 \\
& 7.0 \\
& 0.7 \\
& 0.0 \\
& 3 \\
& 0 \\
& 0 \\
& 0\end{aligned}$ & 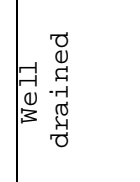 & 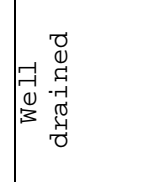 & 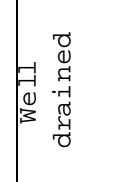 & 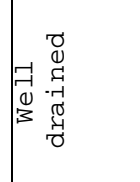 & 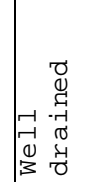 & 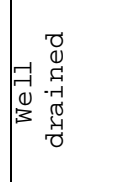 \\
\hline $\begin{array}{l}\text { H } \\
\text { O } \\
\text { y } \\
1 \\
1 \\
\text { y } \\
1\end{array}$ & 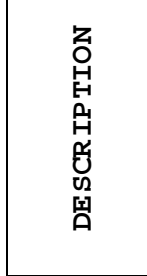 & 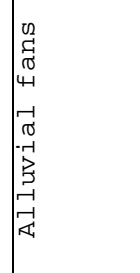 & 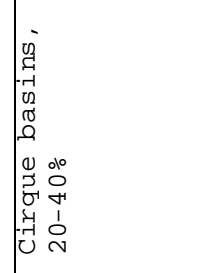 & 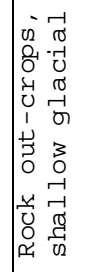 & 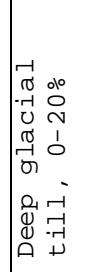 & 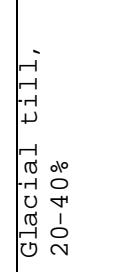 & 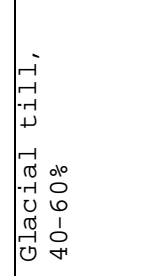 & 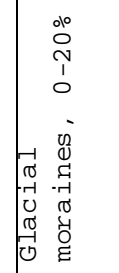 & 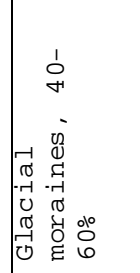 & 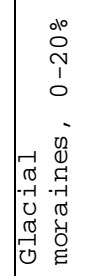 & 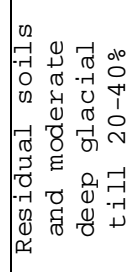 \\
\hline $\begin{array}{l}\text { 섬 } \\
\text { M } \\
\text { स्ञ }\end{array}$ & 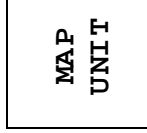 & $\mid \begin{array}{l}0 \\
-1\end{array}$ & $\begin{array}{l}\infty \\
1 \\
\vec{N}\end{array}$ & $\mid \begin{array}{l}a \\
i \\
\vec{N}\end{array}$ & $\begin{array}{l}1 \\
\pi \\
0 \\
0 \\
v \\
v\end{array}$ & $\begin{array}{l}\infty \\
0 \\
0 \\
b \\
N \\
N\end{array}$ & 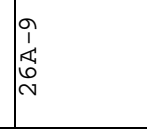 & $\mid \begin{array}{l}1 \\
u \\
0 \\
v\end{array}$ & $\begin{array}{l}0 \\
i \\
0 \\
0 \\
N\end{array}$ & 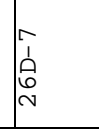 & $\begin{array}{l}a \\
1 \\
\text { in }\end{array}$ \\
\hline & Chapter & III - & terná & & & & & & & Page & III-71 \\
\hline
\end{tabular}




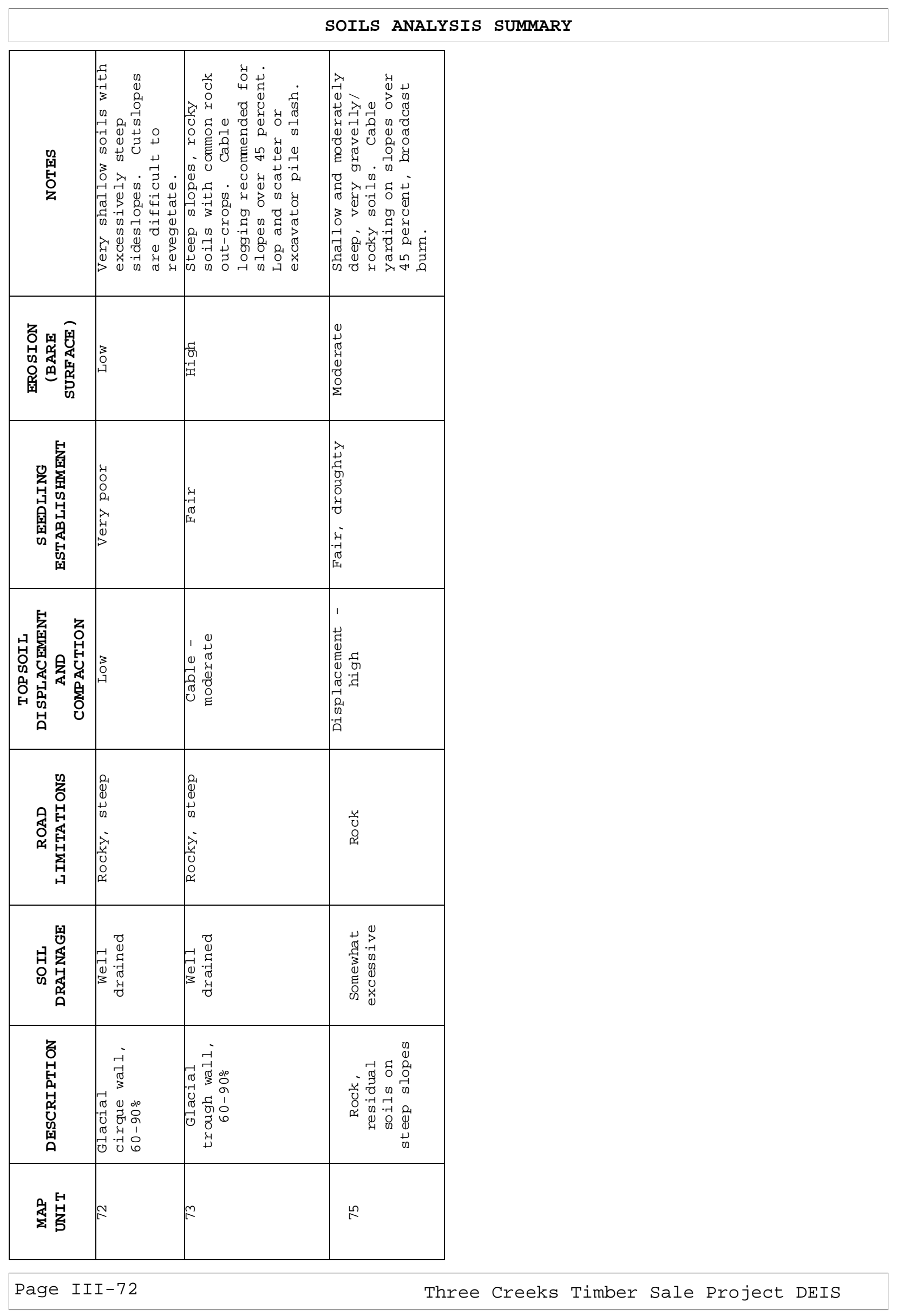




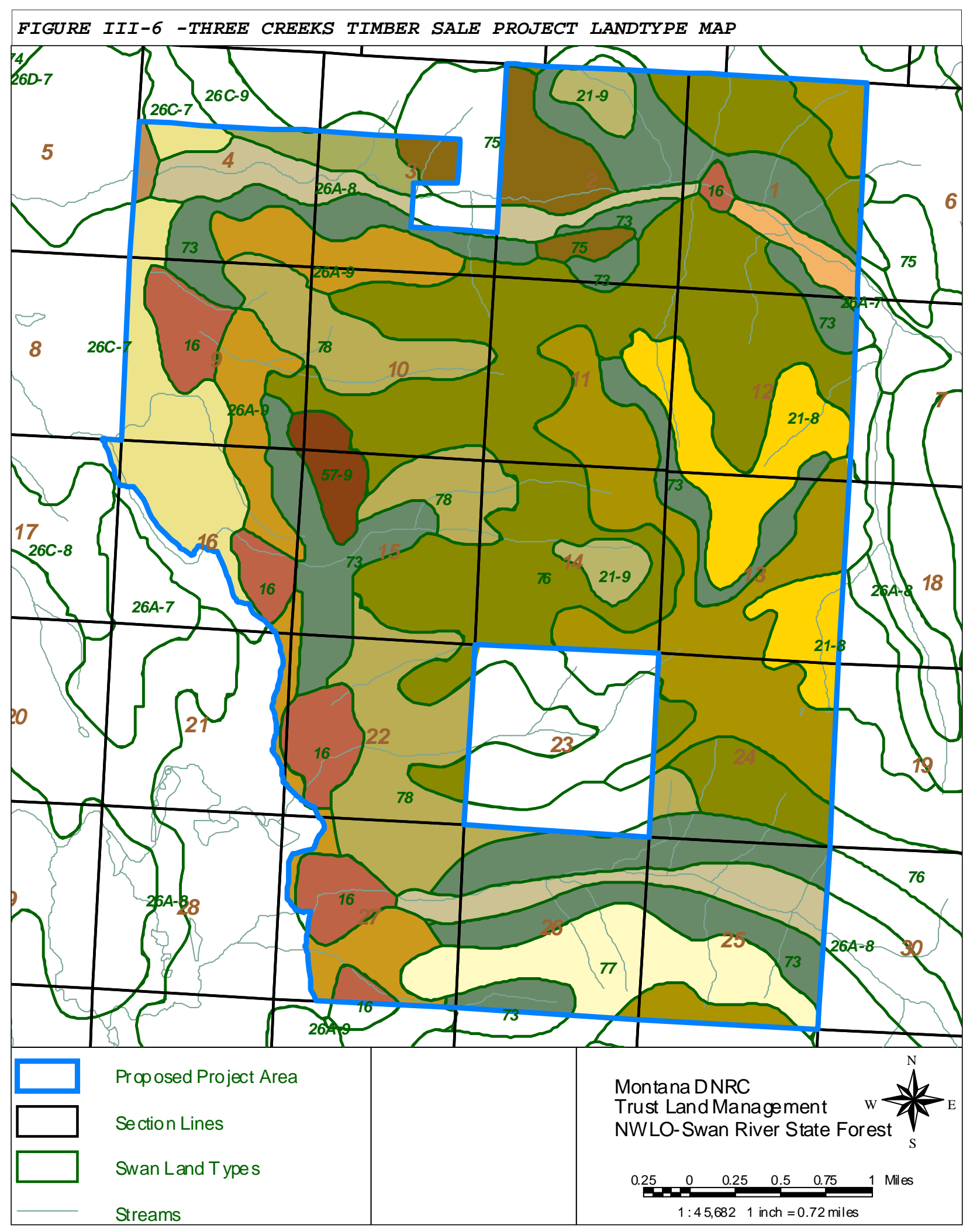




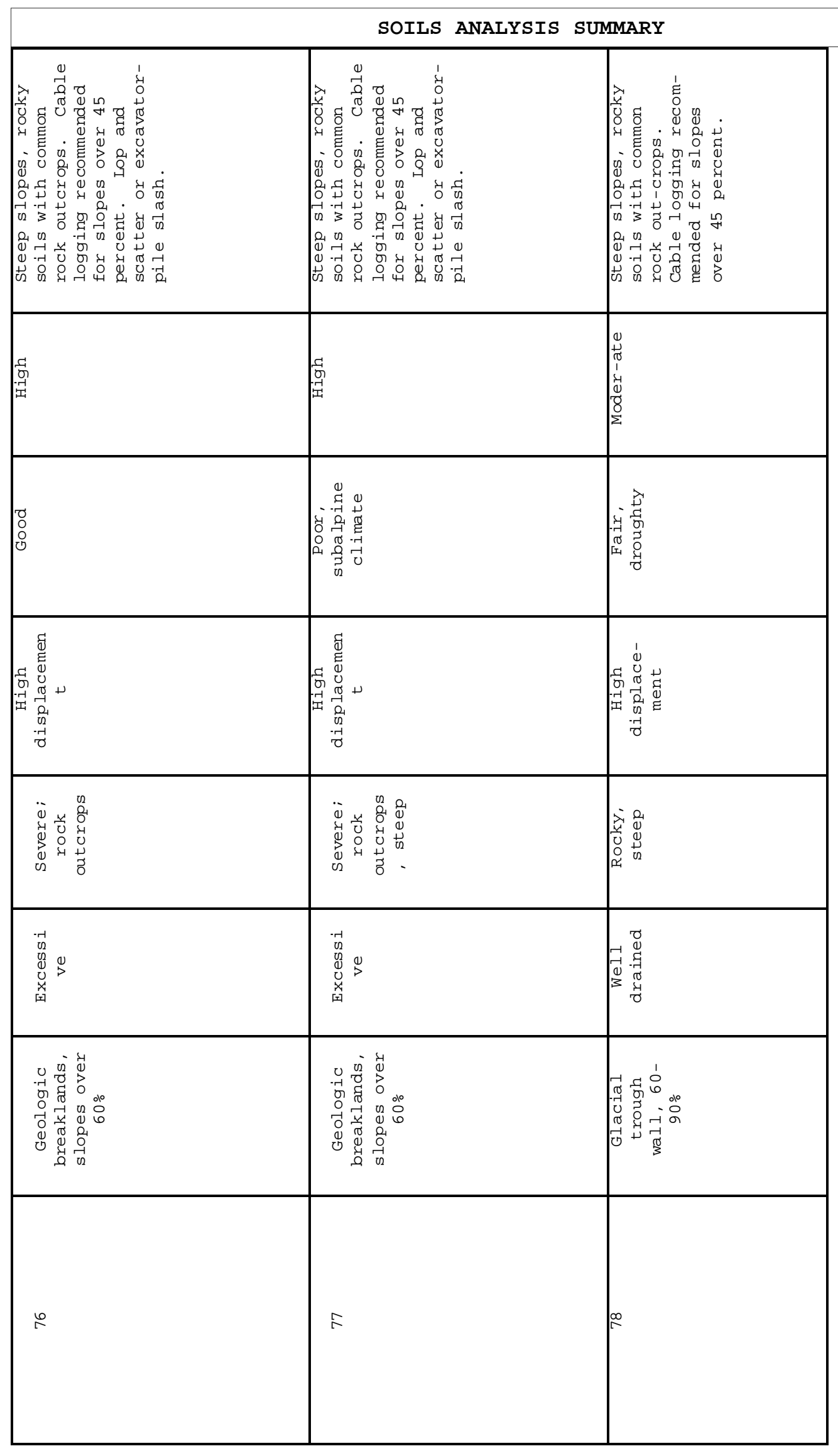




\section{INTRODUCTION}

The proposed timber sale is located in the southeastern corner of Lake County, near the northeastern corner of Missoula County. This section analyzes the economic impacts of the proposed timber sale(s). The emphasis in this section will be on market activities that directly or indirectly benefit the Montana education system, generate revenue for the school trust fund, and provide funding for public buildings. Generation of income for the school trust and public buildings from school trust forestlands is required under the Enabling Act of 1889, as well as the State of Montana Constitution.

\section{EXISTING CONDITIONS}

Enrollment in Montana schools in grades kindergarten through 12 was 146,705 in fiscal year 2004. The most recent information indicates that the cost of educating 1 student per year is, on average, $\$ 7,080$.

Income from timber sales is deposited in the State's general fund where the revenue is allocated to various educational institutions through the legislative process. Local school districts also raise income through property taxes. The taxable value of property is an important factor that influences the ability of a local school district to generate tax revenue.

\section{ALTERNATIVE EFFECTS}

\section{DIRECT EFFECTS}

\section{- Direct Economic Effects of the.No-.Action Altermative. $\boldsymbol{I}$}

No income would be provided to the schools. General fund revenues would be needed to replace the money that would be generated by the selection of one of the action alternatives.

\section{- Direct Ecomomic Effects of.Action . Alternative $\boldsymbol{B}$}

An estimated $\$ 3,459,900$ in trust income would be generated for the school trust fund, enough revenue to send 489 children through school for a year with no other financial aid.

\section{- Direct Ecomomic Effects of.Action .Alternative C}

An estimated $\$ 3,309,800$ in trust income would be generated for the school trust fund, enough revenue to send 467 children through school for a year with no other financial aid. Action Alternative C project expenditures are estimated to be $\$ 2,221,300$ the lowest of all the alternatives. This alternative provides the highest amount of revenue per acre.

\section{- Direct Economic Effects of Action .Altermative $\boldsymbol{D}$}

An estimated $\$ 3,505,300$ in trust income would be generated for the school trust fund, enough revenue to send 495 children through school for a year with no other financial aid. One of the objectives of Action Alternative D was infrastructure development. This has resulted in the highest estimated project expenditure level of $\$ 2,486,200$.

\section{- Direct Economic Effects of.Action Altermative $\boldsymbol{E}$}

An estimated $\$ 3,301,400$ in trust income would be generated for the school trust fund, enough revenue to send 466 children through school for a year with no other financial aid. This alternative was designed to minimize impacts on old growth and limit road construction. This alternative has estimated project expenditures of $\$ 2,349,300$. These are slightly higher than Action Alternative B, however, because of the helicopter logging associated with this project the stumpage price was also reduced to reflect 
the higher logging costs that the purchaser must pay.

\section{INDIRECT EFFECTS}

One of the indirect impacts of timber sales is the employment generated and the income provided to those workers who obtain jobs as a result of the timber harvest. The estimated employment in the forest industry in Montana is 10.58 jobs for every mmbf of timber harvested. The annual income associated with these jobs is $\$ 38,874$ per year per job based on a weighted average of the incomes in the timber industry in Flathead, Lake, and Missoula counties. Using this information, together with the timber harvesting associated with each of the alternatives, an estimate of the wage and salary income generated from each of the alternatives is shown in TABLE III-12 - EMPLOYMENT AND EARNINGS IMPACT.

The Three Creeks Timber Sale Project indirectly provides school revenue through property and income taxes generated by the jobs the timber sales creates. Secondary employment and income are also generated, as workers who are directly employed as a result of the timber sales spend their income in other areas of the economy .

\section{CUMULATIVE EFFECTS}

This sale would be part of the annual harvest of timber from the State of Montana forest trust lands. The net revenue from this sale would

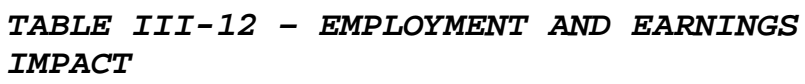

\begin{tabular}{|c|c|c|}
\hline ALTERNATIVE & $\begin{array}{c}\text { JOBS } \\
\text { SUPPLIED }\end{array}$ & $\begin{array}{c}\text { TOTAL } \\
\text { INCOME }\end{array}$ \\
\hline A & 0 & 0 \\
\hline B & 252 & $\$ 9,779,600$ \\
\hline C & 241 & $9,350,200$ \\
\hline D & 273 & $10,610,400$ \\
\hline E & 254 & $9,860,600$ \\
\hline
\end{tabular}

add to this year's revenue to the trust fund. Annual contributions have varied widely over the years because the actual contribution to the trust is more a function of harvest than of sales.

Harvest levels can vary substantially over time; sales tend to be more consistent. Annual revenue from harvests for the last 5 years is shown in TABLE III-13 ANNUAL REVENUE FROM TIMBER HARVESTED FROM MONTANA SCHOOL TRUST LANDS. The net contribution to the trust fund is also affected by the annual costs experienced by the Department for program management, which varies year to year. The Department should continue to make net annual contributions to the trust from its forest management program.

DNRC has a State-wide sustainedyield annual harvest goal of 53.2 mmbf. If timber from this project is not sold, this volume could come from sales elsewhere; however, the timber may be from other areas and not benefit this region of the State. The impacts of obtaining the harvest from other areas of the state would depend on the area selected and would result in different impacts. The forest will not be available for harvesting consideration again for 20 to 60 years, depending on the treatment each area receives. This harvest is consistent with the treatments prescribed in the SFLMP.

\section{TABLE III-13 - ANNUAL REVENUE FROM TIMBER HARVESTED FROM MONTANA SCHOOL TRUST LANDS}

\begin{tabular}{|c|c|}
\hline YEAR & $\begin{array}{l}\text { HARVEST } \\
\text { REVENUE }\end{array}$ \\
\hline 2005 & $\$ 16,596,191$ \\
\hline 2004 & $11,043,525$ \\
\hline 2003 & $8,278,792$ \\
\hline 2002 & $9,686,844$ \\
\hline 2001 & $8,524,150$ \\
\hline
\end{tabular}




\section{INTRODUCTION}

The general public uses the Three Creeks Timber Sale Project area for various recreational uses. The methodologies used to portray the existing condition and determine the impacts this project would have on recreation included determining the recreational uses, approximating the revenue received from recreational uses, and determining the potential for conflict between the timberharvesting activities and recreational uses. The analysis area includes all legally accessible State land within the project area and the roads that would be used to haul equipment and logs. The estimated dollars for comparing alternatives and making decisions may not reflect the actual returns or costs.

\section{EXISTING CONDITION}

The project area receives recreational use throughout the year. The primary uses are: berry picking, snowmobiling, bicycling, fishing, hiking, hunting, and camping.

State lands are available for nonmotorized recreational use to anyone purchasing a General Recreational Use License for State lands. Revenue from these licenses for the project area is approximately $\$ 1,447.04$ per year. Swan River State Forest has 3 hunting outfitter licenses, 5 river outfitter licenses, one cross country skiing recreational use license, and a permit pending for horseback riding that includes the project area. The annual rental fees for these licenses total is $\$ 6,100.00$.

\section{ALTERNATIVE EFFECTS}

\section{DIRECT EFFECTS}

\section{- Direct Effects of. NorAction .Altermative A on Recreation}

Recreation would not be affected.

\section{- Direct Effects Common to Action .Alternatives $\boldsymbol{B}, \boldsymbol{C}, \mathrm{D}$, and $\mathrm{E}$ on Recreation}

Hunter success may be affected by disturbing normal game movement patterns with harvesting activities. Log hauling, snowplowing, and short delays during road-construction activities may inconvenience snowmobilers, bicyclists, and other recreationalists. However, recreational use and revenue income from outfitting and General Recreational Use Licenses are not expected to change with the implementation of this project.

Timber harvesting is scheduled for the Soup Creek Campground and a stand that is adjacent to the campground. Harvesting operations would be planned for the winter (late November through March) to limit effects of recreational use in the campground.

\section{INDIRECT EFFECTS}

\section{- Indirect Effects of . Vo-.Action .Alternative A on Recreation}

No change to the existing condition is expected.

\section{- Indirect Effects Common to Action Alternatives $\boldsymbol{B}, \boldsymbol{C}, \mathrm{D}$, and $\mathrm{E}$ on Recreation}

The amount of recreational use within the project area may change during project implementation. Recreational users may use adjacent areas to avoid harvesting and loghauling activities. Recreational use and revenue income from outfitting, General Recreational Use Licenses, and wildlife conservation licenses are not expected to change. 


\section{CUMULATIVE EFFECTS}

\section{- Cumulative Effects of. Vo-.Action Altermative.A} on Recreation

Some recreational users may be reluctant to use roads within the project area if roads proposed for hauling and harvesting activities continue to deteriorate due to lack of maintenance associated with commercial activity. However, recreational use and revenue income from outfitting and General Recreational Use Licenses are not expected to change.

\section{- Cumulative Effects of Actiom .Alternatives B, C,} D, and E on Recreation

The harvesting and log-hauling activities within the project area may temporarily displace recreational use to adjacent areas outside the project area. All levels of existing recreational use on Swan River State Forest are expected to continue. Therefore, revenue income from outfitting, General Recreational Use Licenses, and wildlife conservation licenses are not expected to change. 


\section{INTRODUCTION}

Air quality could be affected by the smoke created from burning the slash that is produced from harvesting timber and road dust generated by project-related activities such as log hauling. The methodologies used to analyze how the air quality would be affected include estimating the location, amount, and timing of smoke and road dust. The analysis area for air quality includes all of Lake County, which is part of Montana Airshed 2, as defined by the Montana/Idaho Airshed Group.

\section{EXISTING CONDITION}

Currently, the project area contributes very low levels of air pollution to the analysis area or local population centers. Temporary reductions to air quality currently exist in the summer and fall due to smoke generated from prescribed burns and dust produced by vehicles driving on dirt roads; neither affect local population centers beyond EPA standards. All burning activities comply with emission levels authorized by the Montana/ Idaho Airshed Group for all major burners in the analysis area. The project area is outside of any local impact zones, where additional restrictions may be imposed to protect air quality.

\section{ALTERNATIVE EFFECTS}

\section{DIRECT EFFECTS}

\section{- Direct Effects of.No-Action .Atermative.A on Air Quality}

The existing condition would not change.

\section{- Direct Effects Common to Action .Alternatives} B, C, D, and E om .Air Quality

Postharvest burning would produce smoke emissions; log hauling and other project-related traffic on dirt roads would increase road dust during dry periods. No increase in emissions is expected to exceed standards or impact local population centers or the class 1 airsheds that exist to the east within the Bob Marshall Wilderness Area, provided that burning is completed within the requirements imposed by the Montana/Idaho Airshed Group and dust abatement is applied to roads during dry periods.

\section{INDIRECT EFFECTS}

\section{- Indirect Effects of .Vo-.Action .Altermative.A on Air Quality}

The existing condition would not change.

\section{- Indirect Effects Common to .Action Alternatives B, C, D, and E on .Air Quality}

Since emissions are expected to remain within the standards set for air quality, no indirect effects to human health at local population centers are anticipated.

\section{CUMULATIVE EFFECTS}

\section{- Cumulative Effects of. Vo-Action .Alternative.A on.Air Quality}

The existing condition would not change.

\section{- Cumulative Effects Common to .Action -Alternatives B, C, D, and E on .Air Quality}

Additional smoke produced from prescribed burning on adjacent USFS, private, and state trust forestland would remain within the standards for air quality, but cumulative effects during peak burning periods could affect individuals that have respiratory illnesses at local population centers for short durations. All known major burners operate under the requirements of the Montana/ Idaho Airshed Groups, which regulate the amount of emissions produced cumulatively by major burners. 


\section{INTRODUCTION}

The public generally views the project area while sightseeing. The views of vegetation and topography that are next to roads or trails are known as foreground views. The views of hillsides or drainages from roads and trails are known as middleground views. The views of horizons, mountain ranges, or valleys are known as background views. The existing condition and the impacts to the current views are presented from the perspective of these 3 viewing categories. The foreground and middleground views are discussed in regard to changes in vegetation, soil, and timber stands along roads. Background views were analyzed based on the openness of the proposed harvest areas and the patterns of trees that would be left in those areas. The analysis areas for the foreground and middleground views are along South Fork Lost Creek, Cilly Creek, and Soup Creek roads. The analysis area for background views is the central Swan Range on the east side of Swan River state Forest, as viewed from Highway 83.

\section{EXISTING CONDITION}

Generally, foreground views along open roads are limited to 200 feet and contain views of open and dense forest stands and openings caused by past harvesting. Firewood gathering and salvage logging have caused some damage to live trees; limbs and tops are scattered along roads and ditches.

Middleground views are 200 to 1,000 feet from a road or trail and usually consist of hillsides or drainages. On state ownership, areas that have been harvested in the past range in size from 10 to 150 acres and have a dense cover of 6- to 40-foot trees. Many old harvest-unit boundaries usually follow straight lines, and, therefore, appear unnatural.
Background views of the project area are a collection of drainages and ridges that make up a portion of the central Swan range. The vegetation is a mixture of dense mature forests and past harvest units that range from having few trees to dense tree regeneration.

\section{ALTERNATIVE EFFECTS}

\section{DIRECT EFFECTS}

\section{- Divect Effects of.NovAction Altermative.A to -Aesthetics}

Due to lack of forest-management activities, shrubs and trees would continue to grow along the roads and limit views.

\section{- Direct Effects Common to .Action .Alternatives $\boldsymbol{B}, \boldsymbol{C}, \mathrm{D}$, and $\mathrm{E}$ to.Aesthetics}

A variety of treatment methods have been utilized and include commercial thinning, seedtree, seedtree with reserves, shelterwood, and, at soup Creek Campground, sanitation. The acreage proposed for treatment varies by alternative as described in CHAPTER II - ALTERNATIVES.

These treatments would aesthetically affect the harvest area by:

- opening the view,

- causing some damage to residual vegetation,

- creating logging slash,

- disturbing soil along skid trails and landings,

- constructing new roads, and

- creating temporary landing piles along roads within the project area.

Generally, the foreground views would be altered because there would be fewer residual trees. In some of the project area, the treatments would make the middleground visible. The middleground views would appear altered, more open, and have fewer residual trees. The background views, only visible from the soup 


\section{AESTHETICS ANALYSIS SUMMARY}

Creek Road/Highway 83 junction, would appear altered and show a variety of tree densities remaining on the landscape.

\section{INDIRECT EFFECTS}

\section{- Indirect Effects of. Vo Action .Atternative.A to Aesthetics}

Aesthetics would not be indirectly affected.

\section{- Indirect Effects of Action . Atternatives B, C, D, and E to.Aesthetics}

For units that would be treated by seedtree or seedtree with reserves, tree density in the area affected would appear similar to the results of a moderately severe fire. For the other treatment-type areas, the tree density remaining would appear similar to the results of a lowintensity fire of mixed severity. In both scenarios, the species retained will typically be those of early seral stages that would survive these types of fires.

\section{CUMULATIVE EFFECTS}

The following effects of other projects may influence the cumulative effects of aesthetics upon the 3 viewing categories:

Environmental processes on the landscape, such as wildfires, windstorms, insect infestations, and disease infections, would continue to alter views over time.

Salvage harvesting and firewood gathering would alter the foreground by damaging vegetation along roads and leaving some debris on the road and skid trail surfaces and in ditches. The administration of salvage permits by DNRC would keep roadside debris to a minimum. Middleground views would appear altered with fewer trees. Background views would remain largely unaltered due to the minimal size of the salvage harvest areas on the landscape.
Previous harvest units, of the Goat Squeezer timber sales, south of the project area, have resulted in altered views with fewer trees along all 3 viewing categories. 


\section{IRRETRIEVABLE AND IRREVERSIBLE COMMITMENTS OF NATURAL RESOURCES}

\section{IRRETRIEVABLE}

A resource that has been

irretrievably committed is lost for

a period of time. Many timber

stands in the project area are

mature; some individual trees are more than 150 years old. Any of the timber-harvesting alternatives would cause live trees to be irretrievably lost; they would no longer

contribute to future snag

recruitment, stand structure and compositional diversity, aesthetics, wildlife habitat, the nutrientrecycling process, or any other important ecosystem functions.

Areas converted from timber production to permanent roads would be lost from timber production and would not function as forested lands for a period of time.

\section{IRREVERSIBLE}

A resource that has been irreversibly committed cannot be reversed or replaced. The initial loss of trees due to timber harvesting would not be irreversible. Natural regeneration combined with site preparation and artificial regeneration would promote the establishment of new trees. If management decisions allowed for the continued growth of established trees, they would ultimately become equivalent in size to the irretrievably harvested trees.

Areas that are initially lost to timber production through road construction could, over time, be reclaimed and once again produce timber and function as forested land. 
IRRETRIEVABLE AND IRREVERSIBLE COMMITMENTS OF NATURAL RESOURCES 


\section{PREPARERS AND CONTRIBUTORS}

\section{DECISIONMAKER}

Daniel Roberson, Swan Unit Manager, DNRC, Swan River State Forest 34925 MT Highway 83

Swan Lake, Montana 59911

\section{ID TEAM MEMBERS}

Kristen Baker, Management Forester Swan River State Forest 34925 MT Highway 83

Swan Lake, Montana 59911

Allen Branine, Unit Fire Supervisor Swan River State Forest

34925 MT Highway 83

Swan Lake, Montana 59911

Jim Bower,

Fisheries Program Specialist

Forest Management Bureau

2705 Spurgin Road

Missoula, Montana 59804

Paul Engelmann, Forest Economist

Forest Management Bureau

2705 Spurgin Road

Missoula, Montana 59804

Karen Jorgenson,

Management Forester/Project Leader

Swan River State Forest

34925 MT Highway 83

Swan Lake, Montana 59911

Norm Merz, Wildlife Biologist

Northwestern Land Office

2250 Highway 93 North

Kalispell, Montana 59901

Tony Nelson, Hydrologist

Northwestern Land Office

2250 Highway 93 North

Kalispell, Montana 59901

Sarah Pierce, MEPA Specialist

Forest Management Bureau

2705 Spurgin Road

Missoula, Montana 59804

Allen Wolf, Trust Lands Professional Northwestern Land Office 2250 Highway 93 North

Kalispell, Montana 59901
TECHNICAL SUPPORT AND ASSISTANCE

Ross Baty, Wildlife Biologist

Forest Management Bureau

2705 Spurgin Road

Missoula, Montana 59804

Margaret Beck,

Graphics and Publication Technician

Stillwater state Forest

PO Box 164

Olney, Montana 59927

Jeff Collins,

Hydrologist/Soil Scientist

Southwestern Land Office

$140127^{\text {th }}$ Avenue

Missoula, Montana 59804

Brennan Ferguson, Forest Pathologist

Ferguson Forest Pathology

Consulting, Inc.

PO Box 2127

Missoula, Montana 59806

Gary Frank,

Supervisor Resource Management

Forest Management Bureau

2705 Spurgin Road

Missoula, Montana 59804

Wanemah Hulett,

Graphics and Publication Technician

Swan River State Forest

34925 MT Highway 83

Swan Lake, Montana 59911

Scott McLeod,

Supervisor Ecological Section

Forest Management Bureau

2705 Spurgin Road

Missoula, Montana 59804

Donna Riebe,

GIS - Information System Support

Forest Management Bureau

2705 Spurgin Road

Missoula, Montana 59804

Roger Ziesak,

Supervisor State Land Management

Forest Management Bureau

2705 Spurgin Road

Missoula, Montana 59804 


\section{THREE CREEKS TIMBER SALE PROJECT REFERENCES}

Ake, K. 1994. Protocol paper: Moving window motorized access density analysis and security core area analysis for grizzly bear. Unpubl. mimeo., 2/22/1995. Flathead National Forest, Kalispell, MT 10pp

Amman, G.D., McGregor, M.D., and Dolph, R.E., Jr. 1989. Mountain pine beetle. Forest Insect and Disease Leaflet 2 (revised). USDA Forest Service, Washington, D.C. 11 $\mathrm{p}$.

Aney, W. and R. McClelland. 1985. Pileated Woodpecker Habitat Relationships (revised). Pages 1017 in Warren, N. eds. 1990. Old Growth Habitats and Associated Wildlife Species in the Northern Rocky Mountains. USFS, Northern Region, Wildlife Habitat

Relationships Program R1-90-42. $47 \mathrm{pp}$

Antos, J.A., and Habeck, J.R. 1981. Successional Development in Abies grandis (Dougl.) Forbes Forests in the Swan Valley, Western Montana. Northwest Science, Vol. 55, No.1: 26-39

Ausband, D. 2004. Snowshoe hare response to precommercial thinning in Northwest Montana: Final report to the Montana DNRC. Forest Management Bureau, DNRC, Missoula, MT 19pp

Ayers, H.B. 1898. The Flathead Forest Reserve. Twentieth Annual Report, Part 5. pp 245-316

Ayers, H. B. 1899. Lewis and Clarke Forest Reserve, Montana. TwentyFirst Annual Report, Part V PL VIII pp 35-80

Bailey, R.G., Avers, P.E., King, T., and McNab, W.H., comps. and eds. 1994. Ecoregions and subregions of the United States. Color map $(1: 7,500,000)$ and supplementary table of map-unit descriptions. USDA Forest Service and USGS, Washington, DC
Bartholow, J.M. 2002. SSTEMP for Windows: The Stream Segment Temperature Model (Version 2.0). U.S. Geological Survey computer model and documentation

Baxter, C.V. 1997. Geomorphology, land-use, and groundwater-surface water interaction: a multi-scale, hierarchical analysis of the distribution and abundance of bull trout (Salvelinus confluentus) spawning. Master's Thesis, University of Montana, Missoula, MT

Baxter, C.V., C.A. Frissell, and F.R. Hauer. 1999. Geomorphology, Logging Roads, and the Distribution of Bull Trout Spawning in a Forested River Basin: Implications for Management and Conservation. Transactions of the American Fisheries Society. 128:854-867

Beatty, J.S., Filip, G.M., and Mathiasen, R.L. 1997. Larch Dwarf Mistletoe in Forest Insect and Disease Leaflet 169. USDA Forest Service, Washington, DC 7pp

Beschta, R., R. Bilby, G. Brown, L. Holtby and T. Hofstra. 1987. Stream temperature and aquatic habitat: fisheries and forestry interactions. In: Salo, E. and T. Cundy (eds.). Streamside management: forestry and fishery interactions. University of Washington, Institute of Forest Resources, Contribution No. 57. Seattle, WA

Bilby, R.E. and P.A. Bisson. 1998. Function and distribution of large woody debris. In River Ecology and Management: Lessons from the Pacific Coastal Ecoregion. Springer, New York, NY

Bosch, J. M. and Hewlett, J. D., 1982. A Review of Catchment Experiments to Determine the Effect of Vegetation Changes on Water Yield and Evapotranspiration. J. Hydrol., 55:3-23 
Bower, J. 2004. Trends in Large Woody Debris (LWD) Recruitment to Stream Channels in Western Montana (Draft). Unpublished. Department of Natural Resources and Conservation, Missoula, MT

Branine, A. 2006. Montana Department of Natural Resources and Conservation. Personal communication

Bull EL and JA Jackson. 1995. Pileated woodpecker: Dryocopus pileatus. The birds of North America, American Ornithologists' Union, Washington DC $24 \mathrm{pp}$

Bull, E.L., Parks C.G., and Torgersen, T.R. 1997. Trees and Logs Important to Wildlife in the Interior Columbia River Basin. General Technical Report PNW-391. USDA Forest Service, Pacific Northwest Research Station, Portland, OR 55pp

Buskirk, SW and RA Powell. 1994. Habitat ecology of fishers and American martens. Pages 283-296 in Buskirk, SW, A Harestad, M Raphael, eds. Biology and conservation of martens, sables and fishers. Cornell Univ. Press, Ithaca, NY

Byler, J.W., and Hagle, S.K. 2000. Succession Functions of Pathogens and Insects: Ecoregion Sections M332a and M333d in Northern Idaho and Western Montana. Summary. Region 1 FHP Report 00-09. USDA Forest Service, Northern Region, State and Private Forestry, Missoula, MT 37pp

Callahan, Paul. 2000. Forest Road Sedimentation Assessment Methodology. Land and Water Consulting, Inc

Castelle, A. and A. Johnson. 2000. Riparian Vegetation Effectiveness. National Council for Air and Stream Improvement, Technical Bulletin No. 799
Currier, J. and D. Hughes. 1980. Temperature. In: An approach to water resources evaluation on nonpoint silvicultural sources. EPA600/8-80-12. U.S. Environmental Protection Agency, Environmental Research Laboratory, Athens, GA

Department of Natural Resources (DNRC). 2003. Goat Squeezer Final Environmental Impact Statement. Montana DNRC, Swan Lake, MT 418 pp

Department of State Lands, Idaho Department of Lands, USFS 1996

Forest Insect and Disease

Identification and Management

DNRC. 1996. State Forest Land Management Plan. Montana Department of Natural Resources and Conservation, Missoula, MT

DNRC. 1998. South Fork Lost Creek Supplemental Environmental Impact Statement. Montana Department of Natural Resources and Conservation, Swan Lake, MT $182 \mathrm{pp}$

DNRC. 2000. State forest Land management plan implementation guidance-draft: old-growth management on school trust lands. Unpublished document, August 7, 2000. Missoula, MT: DNRC Forest Management Bureau. $72 \mathrm{p}$

Dobson, A., K. Ralls, M. Foster, M.E. Soule, D. Simberloff, D. Doak, J.A. Estes, L.S. Mills, D. Mattson, R. Dirzo, H. Arita, S. Ryan, E.A. Norse, R.F. Noss, and David Johns. 1999. Corridors: Reconnecting fragmented landscapes. Pages 129170 in M.E. Soule and J. Terbourgh, eds. Continental conservation: Scientific foundations of regional reserve networks. Island Press, Washington, DC

Downs, C.C., R.G. White, B.B. Shepard. 1997. Age at Sexual Maturity, Sex Ratio, Fecundity, and Longevity of Isolated Headwater Populations of Westslope Cutthroat Trout. North American Journal of Fisheries Management. 17:85-92 
Etheridge, D.E., and Hunt, R.S. 1978. True Heartrots of British Columbia. Pest Leaflet 55. Canadian Forestry Service, Pacific Forest Research Centre, Victoria, BC $10 \mathrm{pp}$

FBC (Flathead Basin Commission). 1991. Final Report. Flathead Basin Forest Practices Water Quality and Fisheries Cooperative Program, Kalispell, MT

Farns, P. 1978. Hydrology of Mountain Watersheds, Preliminary Report. Soil Conservation Service. Bozeman, MT

Ferrell, G.T. 1986. Fir engraver. Forest Insect and Disease Leaflet 13. USDA Forest Service, Pacific Southwest Forest and Range Experiment Station, Berkeley, CA 8pp

Filip, G.M., P.E. Aho, and M.R. Witala. 1983 Indian paint fungus: a method for reducing Hazard in Advanced Grand and White Fir Regeneration in Eastern Oregon and Washington. Report R6-FPM-PR-29387. USDA Forest Service, Pacific Northwest Region, Portland, OR $24 \mathrm{pp}$

Filip, G.M., and D.J. Goheen. 1984 . Root Diseases Cause Severe Mortality in White and Grand Fir stands of the Pacific Northwest. Forest Science 20:138 through 142

Fins, L., J. Byler, D. Ferguson, A. Harvey, M.F. Mahalovich, G. McDonald, D. Miller, J. Schwandt, and A. Zack. 2001. Return of the Giants. Station Bulletin 72 . University of Idaho, Moscow 20pp

Fischer, R.A. and J.C. Fischenich. 2000. Design recommendations for riparian corridors and vegetated buffer strips. ERDC TN-EMRRP-SR-24: $1-17$

Fisher, W.C., A.F. Bradley. 1987. Fire Ecology of Western Montana Forest Habitat Types. USFS General Technical Report. INT-223
Foresman, KR. 2001. The wild mammals of Montana. Special Publication 12. American Society of Mammalogists. Allen Press, KS 278pp

Fraley, J.J. and B.B. Shepard. 1989. Life History, Ecology and Population Status of Migratory Bull Trout (Salvelinus confluentus) in the Flathead lake and River system, Montana. Northwest Science. 63 (4) : 133-143

Freedman, J.D., and Habeck, J.R. 1985. Fire, logging, and whitetailed deer interrelationships in the Swan Valley, northwestern Montana. In Fire's Effects on Wildlife Habitat Symposium Proceedings. Compiled by J.E. Lotan and J.K. Brown, USDA For. Serv. Gen. Tech. Rep. INT-186. pp. 23-35

FWP. 1996. White-tailed Deer Densities and Overall Distribution. Kalispell, MT Lhttp://fwp.mt.gov/ insidefwp/gis/shapefiles/ wtdden.shp.zip>

FWP. 1999. Montana Elk Winter Ranges, Summer Ranges, Calving Areas, and Migration Areas. Kalispell, MT <http://fwp.mt.gov/ insidefwp/gis/shapefiles/ elk99.shp.zip>

FWP. 2003. Montana gray wolf conservation and management plan: Final environmental impact statement. Montana Fish, Wildlife, and Parks, Helena, MT 420pp

FWP. 2004. Mule Deer Distribution and Habitat. Kalispell, MT <http://fwp.mt.gov/insidefwp/gis/ shapefiles/muledr04.shp.zip $>$

Gamett, B. 2002. The Relationship Between Water Temperature and Bull Trout Distribution and Abundance. Master's Thesis. Utah State University, Logan, UT

Gibson, K. 2004. Western larch mortality in western Montana. Report TR-04-11. USDA Forest Service, Region 1 Forest Health Protection, Missoula, Montana. $3 \mathrm{p}$. 
Goheen, D.J., and E.M. Hansen. 1993. Effects of Pathogens and Bark Beetles on Forests. Pages 175 through 196 in Beetle-Pathogen Interaction in Conifer Forests. Schowalter, T.D., and G.M. Filip, eds. Academic Press, San Diego, CA $252 \mathrm{p}$

Graham, RT, AE Harvey, MF Jurgensen, TB Jain, JR Tonn, and DS PageDumroese. 1994. Managing coarse woody debris in forests of the Rocky Mountains. USDA FS Res. Paper. INT-RP-477. 13pp

Green, P., J. Joy, D. Sirucek, W. Hann, A. Zack, and B. Naumann. 1992. Old-growth forest types of the Northern Region. R-1 SES. USDA FS, Northern Region, Missoula, MT 60pp

Groom, M, DB Jensen, RL Knight, S Gatewood, L mills, D. Boyd-Heger, LS Mills, and ME Soule. Buffer zones: Benefits and dangers of compatible stewardship. Pages 171-197 in Soule, M and J Terborgh, eds. 1999. Continental Conservation: Scientific foundation of regional reserve networks. Island Press, Washington DC

Griffith, J.S. 1988. Review of competition between cutthroat trout and other salmonids. American Fisheries Society Symposium 4:134140

Hadfield, J.S., D.J. Goheen, G.M. Filip, C.L. Schmitt, and R.D. Harvey. 1986. Root Diseases in Oregon and Washington conifers. USDA Forest Service. Report R6-FP$250-86$

Hansen, E.M., and K.J. Lewis, editors. 1997. Compendium of Conifer Diseases. APS Press, St. Paul, MN 101p

Hansen, P., R. Pfister, K. Boggs, B. Cook, J. Joy, D. Hinckley. 1995. Classification and Management of Montana's Riparian and Wetland Sites. Miscellaneous Publication No. 54. The University of Montana, Montana Forest and Conservation Experiment Station, Missoula, MT
Harrelson, C.C., C.L. Rawlins, J.P. Potyondy. 1994. Stream Channel Reference Sites: An Illustrated Guide to Field Technique. General Technical Report RM-245. U.S. Department of Agriculture, Forest Service, Rocky Mountain Forest and Range Experiment Station, Fort Collins, CO

Harris, R. 1999. Abundance and characteristics of snags in western Montana Forests. Gen. Tech. Rep. RMRS-GTR-31. Rocky Mountain Research Station, Missoula, MT 19pp

Hart, M. 1989. Past and present Vegetative and Wildife Diversity in Relation to an Existing Reserve

Network: A GIS Evaluation of the Seeley-Swan Landscape, Northwest Montana. Master thesis. University of Montana, Missoula, MT 288pp

Haupt, H.F., et al. 1974. Forest Hydrology Part II Hydrologic Effects of Vegetation Manipulation. USDA Forest Service, Region 1. Missoula, MT

Heinemeyer, $K$ and J. Jones. 1994. Fisher biology and management in the western United States: A literature review and adaptive management strategy. USDA For. Serv. Northern Region, Missoula, MT 108pp

Johnson, S. 1984. Home range, movements, and habitat use of fishers in Wisconsin. M.S. Thesis, Univ. Wiscon, Stevens Point 78pp Jones, J.L. 1991. Habitat use of fisher in northcentral Idaho. M.S. Thesis, Univ. Idaho, Moscow, ID $147 \mathrm{pp}$

Jones, J.L. and E.O. Garton. 1994. Selection of successional stages by fishers in northcentral Idaho. Pages 377-387 in Buskirk, S.W., A.S.

Harestad, M.G. Raphael, and R.A. Powell, eds. Martens, Sables, and fishers: Biology and conservation. Cornell Univ. Press, NY 
Kanda, N., R.F. Leary, F.W. Allendorf. 1997. Population Genetic Structure of Bull Trout in the Upper Flathead River Drainage. Friends of the Bull Trout Conference Proceedings, May 5-7, 1994, 299-308

Kelsey, R.G., and G. Joseph. 1998 . Ethanol in Douglas-fir with Blackstain Root Disease (Leptographium wageneri). Canadian Journal of Plant Pathology 18:194 through 199

Koehler, G.M. 1990. Population and habitat characteristics of lynx and snowshoe hares in north central Washington. Can. J. Zool. 68:845851

Kohler, S. 2003. Montana Department of Natural Resources and Conservation. Personal communication

Koopal, M. 2002a. South Fork Lost Creek R1/R4 Fish Habitat Inventory. Unpublished report prepared for Montana Department of Natural Resources and Conservation, Kalispell, MT

Koopal, M. 2002b. Soup Creek R1/R4 Fish Habitat Inventory. Unpublished report prepared for Montana Department of Natural Resources and Conservation, Kalispell, MT

Koopal, M. 2004. Upper Soup Creek R1/R4 Fish Habitat Inventory. Unpublished report prepared for Montana Department of Natural Resources and Conservation, Missoula, MT

Koplin, J.R. 1972. Measuring predator impact of woodpeckers on spruce beetles. J. Wildl. Manage. $36: 308-320$

Kunkel, K, TK Ruth, DH Pletscher, and MG Hornocker. 1999. Winter prey selection by wolves and cougars in and near Glacier National Park, Montana. J. of Wildl. Manage. 63: 901-910
Leaf, Charles F. 1975. Watershed Management in the Rocky Mountain Subalpine Zone: The Status of Our Knowledge. Research Paper RM137. USDA Forest Service, Rocky Mountain Forest and Range Experiment Station. Ft. Collins, CO

Leathe, S.A, S. Bartelt, L.M. Morris. 1985. Cumulative Effects of Micro-Hydro Development on the Fisheries of the Swan River Drainage, Montana. Vol. III: Fish and Habitat Inventory of Tributary Streams. Bonneville Power

Administration, Division of Fish and Wildlife. Project 82-19

Lesica, Peter. 1996. Using Fire History Models to Estimate Proportions of Old Growth Forest in Northwest Montana, USA.

Conservation Biological Research, University of Montana, Missoula, Montana. Biological Conservation $77: 33$ through 39

Liknes, G.A. and P.J. Graham. 1988 . Westslope Cutthroat Trout in Montana: life history, status, and management. American Fisheries Society Symposium 4:53-60

Livingston, R.L. 1999. Douglas-fir Beetle in Idaho. State Forester Forum No. 18. Idaho Department of Lands, Coeur d'Alene, ID 4pp

Losensky, B.J. 1997. Historical Vegetation in Region one by Climatic Section - Draft Report, Revision Three. USDA Forest Service, Northern Region, Missoula, MT

Losensky, B.J. 1997. Historical Vegetation of Montana. Unpublished report done under contract for Montana Department of Natural Resources and Conservation, Missoula, MT

Losensky, J. 1997. Historical vegetation of Montana. Contract \#970900. Montana DNRC. Missoula, MT $109 \mathrm{pp}$ 
Mace, RD and JS Waller. 1997. Final Report: Grizzly bear ecology in the Swan Mountains, Montana. Montana Fish, Wildlife and Parks, Helena, MT. 191pp

Mace, RD, JS Waller, TL Manley, LJ Lyon, H Zuuring. 1997.

Relationships among grizzly bears, roads, and habitat in the Swan

Mountains, Montana. Pages 64-80 in

Mace, RD and JS Waller. 1997.

Final Report: Grizzly bear ecology

in the Swan Mountains, Montana.

Montana Fish, Wildlife and Parks, Helena, MT 191pp

Maloy, C. 1991. Review of Echinodontium tinctorium 1895-1990. Extension Bulletin 1592. Washington State University Cooperative Extension, Pullman. 29pp

Mathiasen, R.L. 1998. Infection of Young Western Larch by Larch Dwarf Mistletoe in Northern Idaho and Western Montana. Western Journal of Applied Forestry 13:41 through 46

MBTRT (Montana Bull Trout Restoration Team). 2000. Restoration plan for bull trout in the Clark Fork River basin and the Kootenai River basin, Montana. Report prepared for Governor Marc Racicot. Montana Fish, Wildlife and Parks, Helena, MT

MBTSG (Montana Bull Trout Scientific Group). 1996. Swan River drainage bull trout status report (including Swan Lake.) Report prepared for the Montana Bull Trout Restoration Team. Montana Fish, Wildlife and Parks, Helena, MT

MBTSG (Montana Bull Trout Scientific Group). 1998. The Relationship Between Land Management Activities and Habitat Requirements of Bull Trout. Report prepared for the Montana Bull Trout Restoration Team. Montana Fish, Wildlife and Parks, Helena, MT
McClelland, B.R. 1979. The pileated woodpecker in forests of the Northern Rocky Mountains. Pages 283-299 in Role of insectivorous birds in forest ecosystems. Academic Press

McClelland, BR. 1979. The pileated woodpecker in forests of the Northern Rocky Mountains. Pages 283-299 in Role of insectivorous birds in forest ecosystems.

Academic Press

McNeil, W.J. and W.H. Ahnell. 1964. Success of Pink Salmon Spawning Relative to Size of Spawning Bed Materials. U.S. Fish and Wildlife Service. Special Scientific Report: Fisheries No. 469

Mech, LD. 1987. The wolf: the ecology and behavior of an endangered species. Univ. of Minn. Press, Minneapolis $384 \mathrm{pp}$

MFISH (Montana Fisheries Information System). 2005. Montana Fish, Wildlife and Parks, Montana Natural Resource Information system

MNHP (Montana Natural Heritage Program). 2004. Animal Species of Concern. Montana Natural Resource Information system

Montana Department of Environmental Quality. "1996 TMDL Query System." 12 December, 2005. <http:// nris.state.mt.us/wis/tmdlapp/ tmdl96.asp>

Montana Department of Environmental Quality. "2004 TMDL Query System." 12 December, $2005 .<$ http://

nris.state.mt.us/wis/ environet/2004 Home.html>

Montana Department of Environmental Quality. 2005. "Water Quality Protection Plan and TMDLs for the Swan Lake Watershed" 15 December, 2005 <http://www.deq.mt.gov/wqinfo/ TMDL/SwanLake/

Final01SwanMasterDoc.pdf> 
Montgomery, D.R. and J.M.

Buffington. 1997. Channel-Reach

Morphology in Mountain Drainage

Basins. GSA Bulletin. 109(5):596-611

Morrison, D.J., Pellow, K.W., Norris, D.J., and Nemec, A.F.L. 2000. Visible versus actual incidence of Armillaria root disease in juvenile coniferous stands in the southern interior of British Columbia. Can. J. For. Res. 30 : $405-414$

Morrison, D., and K. Mallett. 1996. Slivicultrual Management of Armillaria Root Disease in Western Canadian Forests. Canadian Journal of Plant Pathology 18:194 through 199

Morrison, D., H. Merler, and D. Norris. 1991. Detection, Recognition, and Management of Armillaria and Phellinus Root Diseases in the Southern Interior of British Columbia. Forestry Canada and the British Columbia Ministry of Forests, Victoria, British Columbia, Canada. FRDA Report 179

Morrison, D., and K. Pellow. 1994. Development of Armillaria Root Disease in a 25-Year-old Douglas-fir Plantation in Proceedings of the Eighth International Conference on Root and Butt Rots. IUFRO Working Party S2.06.01. Johansson, M., and J. Stenlid, eds. Swedish University of Agricultural Sciences, Uppsala, Sweden

Morrison, D.J., Pellow, K.W., Norris, D.J., and Nemec, A.F.L. 2000. Visible versus actual incidence of Armillaria root disease in juvenile coniferous stands in the southern interior of British Columbia. Canadian Journal of Forest Research $30: 405-414$.
Morrison, D.J., K.W. Pellow, A.F.L. Nemec, D.J. Norris, and P. Semenoff. 2001. Effects of Selective Cutting on the Epidemiology of Armillaria Root Disease in the Southern Interior of British Columbia. Canadian Journal of Forest Research $31: 59$ through 70

Morrison, D.J., R.E. Williams, and R.D. Whitney. 1991. Infection, Disease Development, Diagnosis, and Detection. Pages 62 through 75 in Armillaria Root Disease. Shaw, C.G., III, and G.A. Kile, eds. USDA Forest Service. Agriculture Handbook 691

Mowat, G, K.G. Poole, and M. O'Donoghue. 2000. Ecology of lynx in northern Canada and Alaska. Chapter 9 in Ruggiero, L.F., K.B. Aubry, S.W. Buskirk, et al., tech eds. Ecology and conservation of lynx in the United States. Univ. Press of Colorado. Boulder, $\mathrm{CO}$. $480 \mathrm{pp}$

Nakano, S., K. Fausch, T. FurukawaTanaka, K. Maekawa, H. Kawanabe. 1992. Resource Utilization by Bull Trout and Cutthroat Trout in a Mountain Stream in Montana, U.S.A. Japanese Journal of Ichthyology. 39 (3) : 211-217

NRIS (Natural Resource Information System). 2004. Westslope Cutthroat Trout Distribution, Swan Drainage, HUC Num: 17010211 (map). Montana State Library, Helena, MT

Otvos, I.S. 1965. Studies on avian predators of Dendroctonus brevicomis Leconte (Coleoptera: Scolytidea), with special reference to Picidae. Can. Entomol. 97: 1184-1199

Otvos, I.S. 1979. The effects of insectivorous bird activities in forest ecosystems: An evaluation. Pages 341-374 in Dickson, J.G., R.N. Conner, R.R. Fleet, J.C. Kroll, and J.A. Jackson, eds. 1979. The role of insectivorous birds in forest ecosystems. Academic Press, New York, NY 
Overton, C.K., S.P. Wollrab, B.C. Roberts, M.A. Radko. 1997. R1/R4 (Northern/Intermountain Regions) Fish and Fish Habitat Standard Inventory Procedures Handbook. General Technical Report INT-GTR346. U.S. Department of Agriculture, Forest Service, Intermountain Research Station, Ogden, UT

Pfankuch, D. J. 1975. Stream Reach Inventory and Channel stability Evaluation. USDA Forest Service, \$1-75-002. Government Printing Office \#696-260/200, Washington DC: 26 pages

Pfister, R.D., B.L. Kovalchik, S.F. Arno, and R.C. Presby. 1977.

Forest Habitat Types of Montana. USDA Forest Service General Technical Report. INT-34

Intermountain For. and Range Exp. Sta. Ogden, UT $174 \mathrm{pp}$

Pierce, John, and Drake Barton. Sensitive plant survey in the Swan River State Forest, Montana. Unpublished report to DNRC. December 2003

Pierce, W.R. 1960. Dwarf mistletoe and its effect upon the larch and Douglas-fir of western Montana. Bulletin No. 10. Montana State University School of Forestry, Missoula. $38 \mathrm{p}$.

Powell, R. 1982. The fisher: National history, ecology, and behavoiur. Univ. Minn. Press, Minneapolis. $217 \mathrm{pp}$

Powell, R and WJ Zielinski. 1994. Fisher. Pages 38-73 in Ruggiero, LF, KB Aubry, SW Buskirk, LJ Lyon, WJ Zielinski, eds. The scientific basis for conserving forest carnivores: American marten, fisher, lynx, and wolverine in the Western United States. US For. Serv. Gen. Tech. Rep. RM-254. 184pp
Pratt, K. 1984. Habitat Use and Species Interactions of Juvenile Cutthroat (Salmo clarki lewisi) and Bull Trout (Salvelinus confluentus) in the Upper Flathead River Basin. Master's Thesis, University of Idaho, Moscow, ID

Quigley, T.M. and S.J. Arbelbide, tech eds. 1997. An Assessment of Ecosystem Components in the Interior Columbia Basin and portions of the Klamath and Great Basins. Gen. Tech. Rep. PNW-GTR-405. Portland, OR: U.S. Department of Agriculture, Forest Service, Pacific Northwest Research station. 4 vol

Ream, RR, DH Pletscher, MW Fairchild, and DK Boyd. 1988. Population and movements of recolonizing wolves in the Glacier National Park area: Annual report: 1 July 1987 - 30 September 1988. Univ. of Montana, Missoula $24 \mathrm{pp}$

Redfern, D.B., and G.M. Filip. 1991. Innoculum and Infection. Pager 48 through 61 in Armillaria Root Disease. Shaw, C.G., III, and G.A. Kile, eds. USDA Forest Service. Agriculture Handbook 691

Rieman, B.E. and G.L. Chandler. 1999. Empirical Evaluation of Temperature Effects on Bull Trout Distribution in the Northwest. Final Report to U.S. Environmental Protection Agency, Boise, ID

Rieman, B.E. and D.L. Myers. 1997. Use of Redd Counts to Detect Trends in Bull Trout (Salvelinus confluentus) Populations. Conservation Biology. 11 (4) :10151018

Rizzo, D.M., R.A. Blanchette, and G. May. 1995. Distribution of

Armillaria ostoyae Genets in a Pinus resinosa-Pinus banksiana Forest.

Canadian Journal of Botany 73:776 through 787

Robinson, E.G. and R.L. Beschta. 1990. Identifying Trees in Riparian Areas That Can Provide Coarse Woody Debris to Streams. Forest Science. $36(3): 790-800$ 
Robinson, R.M., and D.J. Morrison. 2001. Lesion Formation and Host Response to Infection by Armillaria ostoyae in the Roots of Western Larch and Douglas-fir. Forest Pathology 31:371 through 385

Rosgen, D. 1996. Applied River Morphology. Printed Media Companies. Minneapolis, MN

Rosgen, David L. 1996. Applied River Morphology. Wildland Hydrology, Pagosa Springs, CO

Ross, D.W., K.E. Gibson, and G.E. Daterman. 2001. Using $\mathrm{MCH}$ to Protect Trees and Stands From Douglas-fir Beetle Infestation. Report FHTET-2001-09. USDA Forest Service Forest Health Technology Enterprise Team, Morgantown, WV $11 \mathrm{pp}$

Roth, L.F., L. Rolph, and S. Cooley. 1980. Identifying Infected Ponderosa Pine Stumps to Reduce Costs of Controlling Armillaria Root Rot. Journal of Forestry 78:145 through 148,151

Ruediger, B, J Claar, Sl Mighton, B. Nanaey, T. Tinaldi, F. Wahl, N. Warren, D. Wenger, A. Williamson, L. Lewis, B. Holt, G. Patton, J. Trick, A. Vandehey, S. Gniadek. 2000. Canada lynx conservation assessment and strategy ( $2^{\text {nd }}$ edition). USDA For. Serv., USDI Fish and Wildlife Serv., USDI Bureau of Land Management, and USDI National Park Serv. Missoula, MT 122pp

Ruggiero, L.F., K.B. Aubry, S.W. Buskirk, et al. 2000. The scientific basis for lynx conservation: Qualified insights. Chapter 16 In Ruggiero, L.F., K.B. Aubry, S.W. Buskirk, et al (Tech. Eds). 2000. Ecology and conservation of lynx in the United States. Univ. Press of CO, Boulder, CO 480pp

Schmitz, R.F., and K.E. Gibson. 1996. Douglas-fir Beetle. Forest Insect and Disease Leaflet 5. USDA Forest Service, Washington, DC 8pp
Schroeder, L.M., and A. Lindelow. 1989. Attraction of Scolytids and Associated Beetles by Different Absolute Amounts and Proportions of Alpha-pinene and Ethanol. Journal of Chemical Ecology 15:807 through 817

Schwandt, J., and Zack, A. 1996. White pine leave tree guidelines. Report 96-3. USDA Forest Service, Northern Region, Missoula, MT 7pp

Sime, Carolyn A., V. Asher, L. Bradley, K. Laudon, M. Ross, J. Trapp, and L. Handegard. 2006. Montana gray wolf conservation and management in the northern Rockies wolf recovery area. Pages $3-63$ in U.S. Fish and Wildlife Service et al. Rocky Mountain Wolf Recovery 2005 Interagency Annual Report. C.A. Sime and E. E. Bangs, eds. USFWS, Ecological Services, 585 Shepard Way, Helena, MT 59601 130pp

Shepard, B.B., K.L. Pratt, P.J. Graham. 1984. Life Histories of Westslope Cutthroat and Bull Trout in the Upper Flathead River Basin, Montana. Montana Fish, Wildlife and Parks, Kalispell, MT

Sirucek, D.A. and V.C. Bachurski. 1995. Riparian Landtype Survey of the Flathead National Forest Area, Montana. U.S. Department of Agriculture, Forest Service, Kalispel1, MT

Stanford, J.A. and J.V. Ward. 1993. An ecosystem perspective of alluvial rivers: connectivity and the hyporheic corridor. Journal of the North American Benthological Society. $12: 48-62$

Steeger, C, M.M. Machmer, and B. Gowans. 1998. Impact of insectivorous birds on bark beetles: A literature review. Pandion Ecological Research Ltd. Ymir, BC

Streamside Management Rules. 1996. Montana Code Annotated 36.11.311 36.11 .312

SVGBCA. 1997. Swan Valley grizzly bear conservation agreement. USFWS, Helena, MT 37pp 
SVGBCA Monitoring Team. 2004. Swan Valley Conservation Agreement Monitoring Report, Year 2004. USDI FWS. Helena, MT 7pp.

SVGBCA. 1998. The Swan Valley grizzly bear conservation agreement. USDI FWS. Helena, MT 20pp

Sylte, T. and C. Fishenich. 2002. Techniques for Measuring Substrate Embeddedness. EMRRP Technical Note: ERDC TN-EMRRP-SR-36, U.S. Army Engineer Research and Development Center, Vicksburg, MS

Thomas, J., K. Sutherland, B. Kuntz, S. Potts. 1990. Montana Nonpoint Source Management Plan. Montana Department of Health and Environmental Sciences, Water Quality Bureau, Helena, MT

Thomas, JW. 1979. Wildlife habitats in managed forests: the Blue Mountains of Oregon and Washington. US For. Serv. Agriculture Handbook 553. 512pp

Torgersen, T. 1994. Natural enemies in forest insect regulation. Pages 108-111 in Pilarski, M (ed). Restoration Forestry: An international guide to sustainable forestry practices. Kivaki Press

Troendle, Charles A. 1987. The Potential Effect of Partial Cutting and Thinning streamflow from the Subalpine Forest. Rocky Mountain Forest and Range Experiment Station

USDA Forest Service. Flathead National Forest Plan, Amendment 21, DEIS, Management Direction Related to Old Growth Forests. Kalispell, MT 85pp

USDA Forest Service. 1998. Soil Survey of the Flathead National Forest Area, Montana. USDA Forest Service and Natural Resources Conservation Service

USDA Forest Service. 1999. Douglasfir beetle in the Intermountain West. USDA Forest Service pamphlet.
USFWS. 1987. Northern Rocky Mountain wolf recovery plan. USFWS, Denver, CO 119pp

USFWS. 1986. Recovery plan for the Pacific bald eagle. USFWS. Portland, OR 160pp

USFWS. 1993. Grizzly bear recovery plan. Missoula, MT 181pp

USFWS. 1999. Rocky Mountain wolf recovery: 1999 annual report. USFWS. Helena, MT 22pp

USFWS. 2005. Recovery Outline: Contiguous United States Distinct Population Segment of the Canada Lynx. USFWS Mountain-Prairie Region http://mountainprairie.fws.gov/ species/mammals/lynx/final\%20lynx\% 20Recoveryoutline9-05.pdf

USFWS, Nez Perce Tribe, National Park Service, Montana Fish, Wildlife \& Parks, Idaho Fish and Game, and USDA Wildlife Services. 2006. Rocky Mountain Wolf Recovery 2005 Annual Report. C.A. Sime and E. E. Bangs, eds. USFWS, Ecological Services, 585 Shepard Way, Helena, MT 59601 130pp

Warren, N. 1998. Old-growth associated wildlife: status and management recommendations. Flathead National Forest, Land Management Tech. Note No. 16. 9pp Weaver, T. 2005. Montana Department of Fish, Wildlife and Parks, Kalispell, MT Personal Communication

Weaver, T. and J. Fraley. 1991. Fisheries Habitat and Fish Populations. Flathead Basin Commission, Flathead Basin Forest

Practices Water Quality and Fisheries Cooperative Program, Kalispell, MT

Welty, J., T. Beechie, K. Sullivan, D. Hyink, R. Bilby, C. Andrus, G. Pess. 2002. Riparian aquatic interaction simulator (RAIS): a model of riparian forest dynamics for the generation of large woody debris and shade. Forest Ecology and Management. 162:299-318 
Wolman, M.G. 1954. A Method of

Sampling Coarse River-Bed Material.

Transaction American Geophysical

Union. 35 (6):951-956

Young, Stephen L. 1989. Cumulative

Watershed Effects. Lassen National

Forest 


\section{GLOSSARY}

\section{Acre-foot}

A measure of water or sediment volume equal to an amount of material that would cover 1 acre to a depth of 1 foot.

\section{Action alternative}

One of several ways of moving toward the project objectives.

\section{Adfluvial}

A fish that out migrates to a lake as a juvenile to sexually mature and returns to natal stream to spawn.

\section{Administrative road use}

Road use that is restricted to DNRC personnel and contractors for purposes such as monitoring, forest improvement, fire control, hazard reduction, etc.

\section{Airshed}

An area defined by a certain set of air conditions; typically a mountain valley where air movement is constrained by natural conditions such as topography.

\section{Ameliorate}

To make better; improve.

\section{Appropriate conditions} Describes the set of forest conditions determined by DNRC to best meet the SFLMP objectives. The 4 main components useful for describing an appropriate mix of conditions are cover-type proportions, age-class

distributions, stand-structure characteristics, and the spatial relationships of stands (size, shape, location, etc.); all are assessed across the landscape.

\section{Background view}

Views of distant horizons, mountain ranges, or valleys from roads or trails.

Best Management Practices (BMPs) Guidelines to direct forest activities, such as logging and road construction, for the protection of soils and water quality.

\section{Biodiversity}

The variety of life and its processes, including the variety of living organisms, the genetic differences among them, and the communities and ecosystems where they occur.

\section{Board foot}

144 cubic inches of wood that is equivalent to a piece of lumber 1inch thick by 1 foot wide by 1 foot long.

\section{Canopy}

The upper level of a forest consisting of branches and leaves of the taller trees.

\section{Canopy closure}

The percentage of a given area covered by the crowns, or canopies, of trees.

\section{Cavity}

A hollow excavated in trees by birds or other animals. Cavities are used for roosting and reproduction by many birds and mammals.

\section{Centimeter}

A distance equal to .3937 inch.

\section{Commercial-thin harvesting}

A harvest that cuts a portion of the merchantable trees within a stand to provide growing space for the trees that are retained. For the south Wood Timber Sale Project, thinning would reduce stand densities to approximately 100 trees per acre

\section{Compaction}

The increase in soil density caused by force exerted at the soil surface, modifying aeration and nutrient availability.

\section{Connectivity}

The quality, extent, or state of being joined; unity; the opposite of fragmentation.

\section{Core area}

See Security Habitat (grizzly bears). 


\section{Cover}

See HIDING COVER and/or THERMAL

COVER.

\section{Coarse down woody material}

Dead trees within a forest stand that have fallen and begun decomposing on the forest floor.

Crown cover or crown closure

The percentage of a given area covered by the crowns of trees.

Cull

A tree of such poor quality that it has no merchantable value in terms of the product being cut and manufactured.

\section{Cumulative effect}

The impact on the environment that results from the incremental impact of the action when added to other actions. Cumulative impacts can also result from individually minor actions, but collectively they may compound the effect of the actions.

\section{Direct effect}

Effects on the environment that occur at the same time and place as the initial cause or action.

\section{Ditch relief}

A method of draining water from roads using ditches and a corrugated metal pipe. The pipe is placed just under the road surface.

\section{Dominant tree}

Those trees within a forest stand that extend their crowns above surrounding trees and capture sunlight from above and around the crown

\section{Drain dip}

A graded depression built into a road to divert water and prevent soil erosion.

\section{Ecosystem}

An interacting system of living organisms and the land and water that make up their environment; the home place of all living things, including humans.

\section{Embeddeness}

Embeddedness refers to the degree of armour or the tight consolidation of substrate.

\section{Environmental effects}

The impacts or effects of a project on the natural and human environment.

\section{Equivalent clearcut area (ECA)}

The total area within a watershed where timber has been harvested, including clearcuts, partial cuts, roads, and burns.

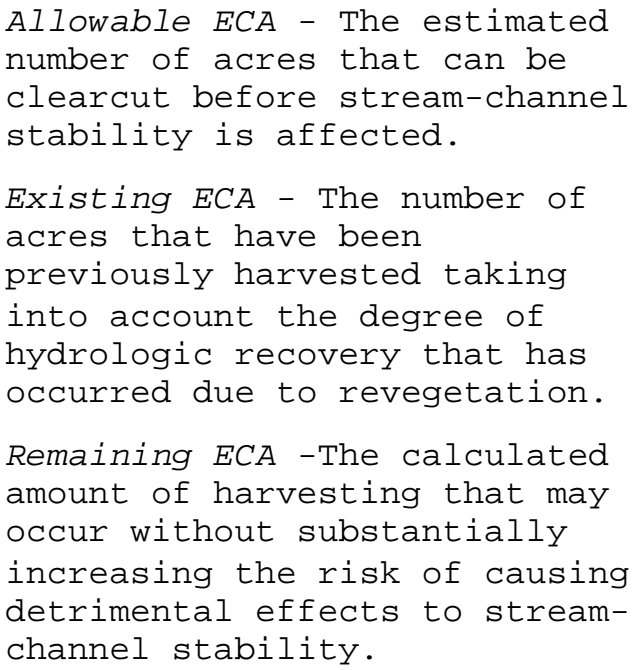

\section{Excavator piling}

The piling of logging residue (slash) using an excavator.

\section{Fire regimes}

Describes the frequency, type, and severity of wildfires. Examples include: frequent, nonlethal underburns; mixed-severity fires; and stand-replacement or lethal burns.

\section{Fluvial}

A fish that outmigrates to a river from its natal stream as a juvenile to sexually mature in the river, and returns to its natal stream to spawn.

\section{Forage}

All browse and nonwoody plants available to wildlife for grazing. 


\section{Foreground view}

The view immediately adjacent to a road or trail.

Forest improvement (FI)

The establishment and growing of trees after a site has been harvested. Associated activities include:

- site preparation, planting, survival checks, regeneration surveys, and stand thinnings;

- road maintenance;

- resource monitoring;

- noxious weed management; and

- right-of-way acquisition on a state forest.

\section{Fragmentation (forest)}

A reduction of connectivity and an increase in sharp stand edges resulting when large contiguous areas of forest with similar age and structural characteristics are interrupted through disturbances, such as stand-replacement fires and timber stand harvesting.

\section{Geomorphological processes}

The observed proportions of habitat

types for each reach are within the broad ranges of expected conditions.

\section{Habitat}

The place where a plant or animal naturally or normally lives and grows.

\section{Habitat type}

Land areas that would produce similar plant communities if left undisturbed for a long period of time.

\section{Harvest units}

Areas of timber proposed for harvesting.

\section{Hazard reduction}

The abatement of a fire hazard by processing logging residue with methods such as separation, removal, scattering, lopping, crushing, piling and burning, broadcast burning, burying, and chipping.

\section{Hiding cover}

Vegetation capable of hiding 90 percent of a standing adult mammal from human view at a distance of 200 feet.

Historical forest condition The condition of the forest prior to settlement by Europeans.

\section{Indirect effects}

Secondary effects that occur in locations other than the initial action or significantly later in time.

\section{Intermediate trees}

Characteristics of certain tree species that allow them to survive in relatively low-light conditions, although they may not thrive.

Interdisciplinary team (ID Team) A team of resource specialists brought together to analyze the effects of a project on the environment.

\section{Landscape}

An area of land with interacting ecosystems.

\section{McNeil Coring}

McNeil coring is a method used to determine the size range of material in streambed spawning sites.

\section{Meter}

A distance equal to 39.37 inches.

\section{Middleground view}

The view that is 200 to 1,000 feet

from a road or trail, usually

consisting of hillsides and

drainages.

Millimeter

A distance equal to .03937 inch.

\section{Mitigation measure}

An action or policy designed to reduce or prevent detrimental effects.

Multistoried stands

Timber stands with 2 or more distinct stories. 
Nest site area (bald eagle)

The area in which human activity or development may stimulate the abandonment of the breeding area, affect successful completion of the nesting cycle, or reduce

productivity. It is either mapped for a specific nest, based on field data, or, if that is impossible, is defined as the area within a $1 / 4-m i l e$ radius of all nest sites in the breeding area that have been active within the past 5 years.

\section{No-action alternative}

The option of maintaining the status quo and continuing present management activities by not implementing the proposed project.

\section{Nonforested area}

A naturally occurring area, (such as a bog, natural meadow, avalanche chute, and alpine areas) where trees do not establish over the long term.

\section{old growth}

Working definition - Old growth as defined by Green et al.

Conceptual definition - The term old growth is sometimes used to describe the later, or older, stages of natural development of forest stands. Characteristics associated with old-growth generally include relatively large old trees that contain a wide variation in tree sizes, exhibit some degree of a multi-storied structure, have signs of decadence, such as rot and spiketopped structure, and contain standing large snags and large down logs.

\section{Old-growth network}

A collection of timber stands that are selected to meet a management strategy that would retain and recruit $150+-y e a r-o l d$ stands over the long term (biodiversity, wildlife, the spatial arrangement of stands and their relationship to landscape patterns and processes) are elements that are considered in the selection of stands.

\section{Overstory}

The level of the forest canopy that include the crowns of dominant, codominant, and intermediate trees.

\section{Patch}

A discrete (individually distinct) area of forest connected to other discrete forest areas by relatively narrow corridors; an ecosystem element (such as vegetation) that is relatively homogeneous internally, but differs from what surrounds it.

\section{Potential nesting habitat (bald eagle)}

Sometimes referred to as 'suitable nesting habitat', areas that have no history of occupancy by breeding bald eagles, but contain potential to do so.

\section{Project file}

A public record of the analysis process, including all documents that form the basis for the project analysis. The project file for the South Wood Timber Sale Project EIS is located at the Swan River state Forest headquarters office at Goat Creek.

\section{Redds}

The spawning ground or nest of various fish species.

\section{Regeneration}

The replacement of one forest stand by another as a result of natural seeding, sprouting, planting, or other methods.

\section{Reinitiation}

The first phase of the process of stand development.

\section{Resident}

Pertaining to fish, resides and reproduces in natal stream.

Residual stand

Trees that remain standing following any cutting operation. 
Road-construction activities

In general, "road-construction

activities" refers to all activities conducted while building new roads, reconstructing existing roads, and obliterating roads. These

activities may include any or all of the following:

- constructing road

- clearing right-of-way

- excavating cut/fill material

- installing road surface and ditch drainage features

- installing culverts at stream crossings

- burning right-of-way slash

- hauling and installing borrow material

- blading and shaping road surfaces

\section{Road improvements}

Construction projects on an existing road to improve the ease of travel, safety, drainage, and water quality.

\section{Saplings}

Trees 1.0 inches to 4.0 inches in $\mathrm{dbh}$.

\section{Sawtimber trees}

Trees with a minimum dbh of 9 inches.

\section{Scarification}

The mechanized gouging and ripping of surface vegetation and litter to expose mineral soil and enhance the establishment of natural

regeneration.

\section{Scoping}

The process of determining the extent of the environmental assessment task. Scoping includes public involvement to learn which issues and concerns should be addressed and the depth of the assessment that will be required. It also includes a review of other factors such as laws, policies, actions by other landowners, and jurisdictions of other agencies that may affect the extent of assessment needed.

\section{Security}

For wild animals, the freedom from

the likelihood of displacement or mortality due to human disturbance or confrontation.

Security habitat (grizzly bears)

An area of a minimum of 2,500 acres that is at least 0.3 miles from trails or roads with motorized travel and high-intensity, nonmotorized use during the nondenning period.

\section{Seedlings}

Live trees less than 1.0 inch $\mathrm{dbh}$.

\section{Seedtree harvesting}

Removes all trees from a stand except for 6 to 10 seed-bearing trees per acre that are retained to provide a seed source for stand regeneration.

\section{Sediment}

Solid material, mineral or organic, that is suspended and transported or deposited in bodies of water.

\section{Sediment yield}

The amount of sediment that is carried to streams.

\section{Seral}

Refers to a biotic community that is in a developmental, transitional stage in ecological succession.

\section{Shade intolerant}

Describes tree species that generally can only reproduce and grow in the open or where the overstory is broken and allows sufficient sunlight to penetrate. Often these are seral species that get replaced by more shade-tolerant species during succession. In Swan River State Forest, shade-intolerant species generally include ponderosa pine, western larch, Douglas-fir, western white pine, and lodgepole pine. 


\section{Shade tolerant}

Describes tree species that can

reproduce and grow under the canopy in poor sunlight conditions. These species replace less shade-tolerant species during succession. In Swan River state Forest, shade-tolerant species generally include subalpine fir, grand fir, Douglas-fir, Engelmann spruce, western hemlock, and western red cedar.

\section{Sight distance}

The distance at which 90 percent of an animal is hidden from view by vegetation.

\section{Silviculture}

The art and science of managing the establishment, composition, and growth of forests to accomplish specific objectives.

\section{Site Preparation}

A hand or mechanized manipulation of a harvested site to enhance the success of regeneration. Treatments are intended to modify the soil, litter, and vegetation to create microclimate conditions conducive to the establishment and growth of desired species.

\section{Slash}

Branches, tops, and cull trees left on the ground following harvesting.

\section{Snag}

A standing dead tree or the portion of a broken-off tree. Snags may provide feeding and/or nesting sites for wildlife.

\section{Spur roads}

Low-standard roads that are constructed to meet minimum requirements for harvesting-related traffic.

\section{Stand}

An aggregation of trees that are sufficiently uniform in composition, age, arrangement, and condition and occupy a specific area that is distinguishable from the adjoining forest.

\section{Stand density}

Number of trees per acre.

\section{Stocking}

The area of a piece of land that is now covered by trees is compared to what could ideally grow on that same area. The comparison is usually expressed as a percent.

\section{Stream gradient}

The slope of a stream along its

course, usually expressed in

percentage, indicating the amount of drop per 100 feet.

\section{Stumpage}

The value of standing trees in the forest. Sometimes used to mean the commercial value of standing trees.

\section{Substrate scoring}

Rating of streambed particle sizes.

\section{Succession}

The natural series of replacement of one plant (and animal) community by another over time in the absence of disturbance.

\section{Suppressed}

The condition of a tree characterized by a low-growth rate and low vigor due to overcrowding competition with overtopping trees.

\section{Texture}

A term used in visual assessments indicating distinctive or identifying features of the landscape depending on distance.

\section{Thermal cover}

For white-tailed deer, thermal cover has 70 percent or more coniferous canopy closure at least 20 feet above the ground, generally requiring trees to be 40 feet or taller. For elk and mule deer, thermal cover has 50 percent or more coniferous canopy closure at least 20 feet above the ground, generally requiring trees to be 40 feet or taller. 


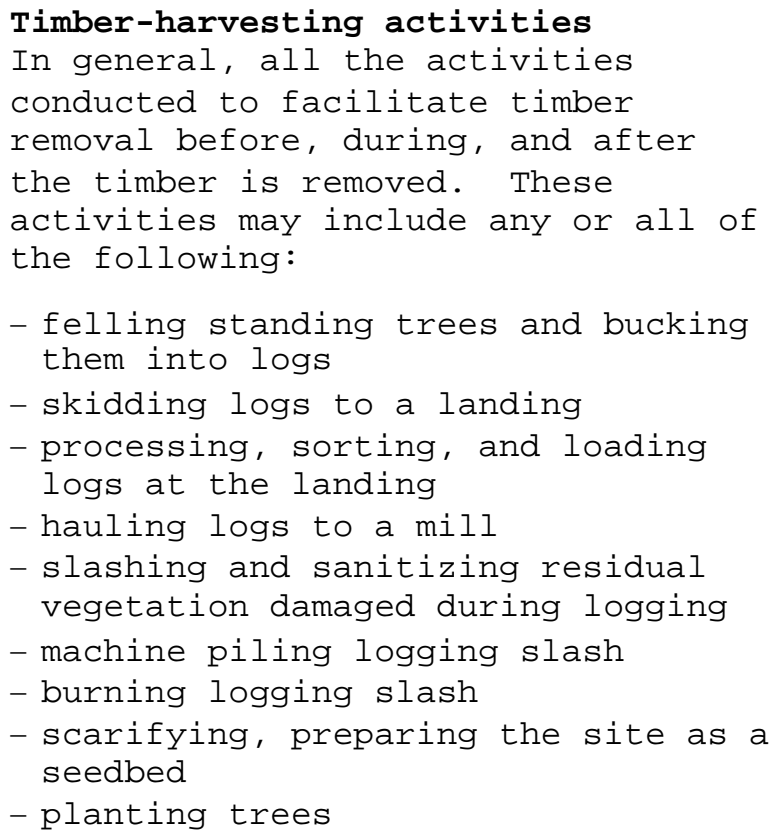

\section{Understory}

The trees and other woody species growing under a, more-or-less, continuous cover of branches and foliage formed collectively by the overstory of adjacent trees and other woody growth.

\section{Uneven-aged stand}

Various ages and sizes of trees

growing together on a uniform site.

\section{Ungulates}

Hoofed mammals, such as mule deer, white-tailed deer, elk, and moose, that are mostly herbivorous and many are horned or antlered.

\section{Vigor}

The degree of health and growth of a tree or stand.

\section{Visual screening}

The vegetation that obscures or reduces the length of view of an animal.

\section{Watershed}

The region or area drained by a river or other body of water.

Water yield

The average annual runoff for a particular watershed expressed in acre-feet.

\section{Water-yield increase}

An increase in average annual runoff over natural conditions due to forest canopy removal. 
ACRONYMS

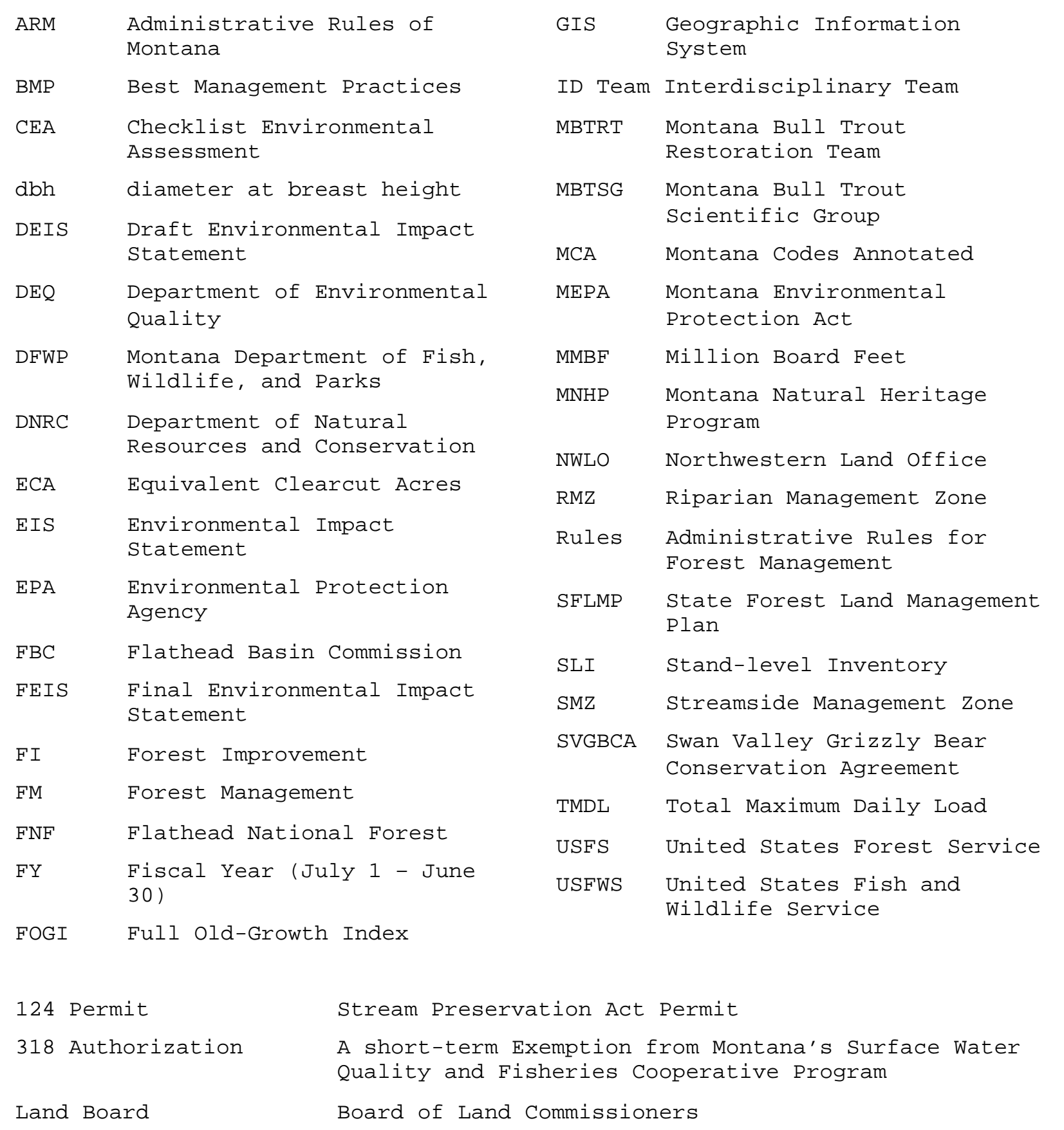


Copies of this document with its appendices were published at an approximate cost of $\$ 12.01$ per copy for printing and $\$ 5.00$ for mailing.

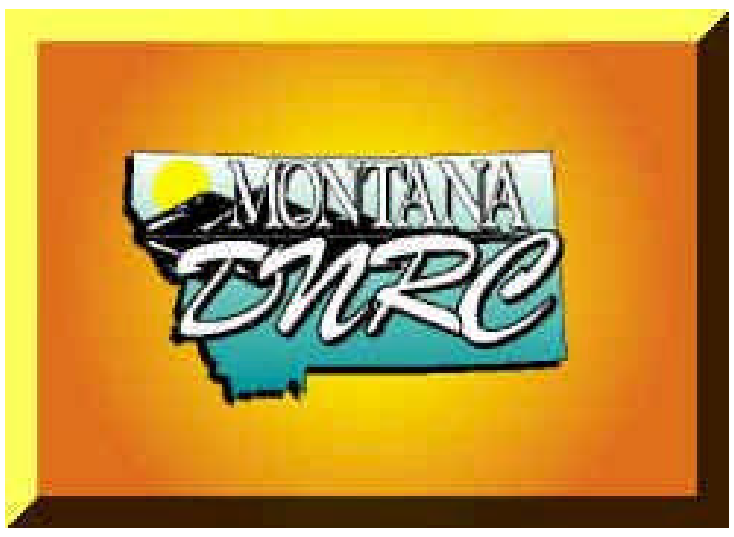

DEPAR'TMENT OF NATURAL RESOURCES AND CONSERVATION

SWAN UNIT OFFICE - SWAN RIVER STA'TE FOREST

34925 M'T HIGHWAY 83

SWAN LAKE, M'T 599II

(406) 754-2301

Persons with disabilities who need an alternative, accessible

Format of this document should contact DNRC

At the address or phone number shown above. 